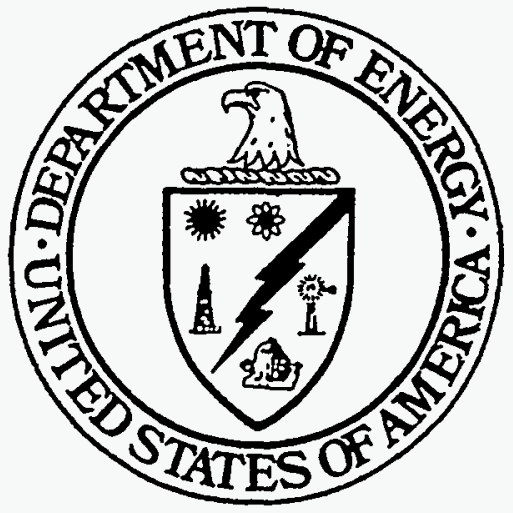

FULL-SCALE DEMONSTRATION OF LOW-NO ${ }_{\mathbf{x}}$ CELL $^{\mathrm{m}}$ BURNER RETROFIT The U.S. Department of Energy
Agreement DE-FC22-90PC90545

Prepared for Under Cooperative Agreement DE-FC22-90PC90545
(B\&W CRD-1250)

Submitted by

Babcock \& Wilcox

Research and Development Division 


\section{FULL-SCALE DEMONSTRATION OF LOW-NO ${ }_{x}$ CELL $^{\text {TM }}$ BURNER RETROFIT}

FINAL REPORT

July 1994

Report DOE/PC/90545-2

(Babcock \& Wilcox Report RDD:94:40090-030-037:01)

Principal Investigators

C. F. Eckhart, J. B. Kitto, R. J. Kleisley, S. C. Kung, and T. Laursen

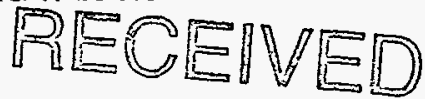

DEC 261995

Sponsored by

DEPArUM UT UEVLLOPRENT $0: 13$ COAL DEV OFFICE

The U. S. Department of Energy

Work Performed Under Cooperative Agreement DE-FC22-90PC90545

(B\&W CRD-1250)

DOE Program Manager

R. Corbett

Babcock \& Wilcox

Research and Development Division

Alliance Research Center

Alliance, Ohlo 44601-2196 


\section{LEGAL NOTICE}

This report was prepared as an account of work sponsored by the United States Government. Neither the United States, nor the United States Department of Energy (DOE), the Babcock \& Wilcox Company (B\&W), nor any of their employees:

a. Makes any warranty or representation, express or implied, with respect to the accuracy, completeness, or usefulness of the information contained in this report, or that the use of any apparatus, method, or process disclosed in this report may not infringe privately owned rights; or

b. Assumes any liability with respect to the use of, or for damages resulting from the use of, any information, apparatus, method, or process disclosed in this report.

Reference herein to any specific commercial product, process, or service by trade name, trademark, manufacturer, or otherwise does not necessarily constitute or imply its endorsement, recommendation, or favoring by the DOE. The views and opinions of the authors expressed herein do not necessarily state or reflect those of the DOE. 


\section{EXECUTIVE SUMMARY}

The "Full Scale Demonstration of Low-NO Cell $^{\mathrm{TM}}$ Burner Retrofit" (Project DE-FC22-90PC90545) is one of the U.S. Department of Energy's (DOE) Clean Coal Technology Phase III (CCT-III) Demonstration Program projects.

Technical and financial support was provided by the following project co-sponsors: DOE, Electric Power Research Institute (EPRI), Dayton Power \& Light (DP\&L), Babcock \& Wilcox (B\&W), State of Ohio Coal Development Office (OCDO), Allegheny Power System, Centerior Energy, Duke Power Company, New England Power Company, and the Tennessee Valley Authority. Representatives (at least one) from each of these co-sponsors made up an advisory committee which provided technical guidance for the project.

The objective of the Low-NO $\mathrm{N}_{\mathrm{x}}$ Cell ${ }^{\mathrm{TM}}$ Burner $\left(\mathrm{LNCB}^{\mathrm{TM}}\right)$ demonstration is to evaluate the applicability of this technology for reducing $\mathrm{NO}_{\mathrm{x}}$ emissions in full-scale, cell burner-equipped boilers. More precisely, the program objectives are to:

- Achieve at least a $50 \%$ reduction in $\mathrm{NO}_{\mathrm{x}}$ emissions.

- Reduce $\mathrm{NO}_{\mathrm{x}}$ with no degradation to boiler performance or life of the unit.

- Demonstrate a technically and economically feasible retrofit technology.

Cell burner equipped boilers comprise $13 \%$ of the Pre-New Source Performance Standards* (NSPS) coal-fired generating capacity. This relates to 34 operating units generating $23,639 \mathrm{MWe}, 29$ of which are opposed wall fired with two rows of two-nozzle cell burners on each wall. The host site was one of these 29 .

Dayton Power \& Light offered use of J. M. Stuart Station's Unit No. 4 as the host site. It was equipped with 24, two-nozzle cell burners arranged in an opposed wall configuration.

To reduce $\mathrm{NO}_{\mathrm{x}}$ emissions, the $\mathrm{LNCB}^{\mathrm{TM}}$ has been designed to delay the mixing of the fuel and combustion air. The delayed mixing, or staged combustion, reduces the high temperatures normally generated in the flame of a standard cell burner. A key design criterion for the burner was accomplishing delayed fuel-air mixing with no pressure part modifications to facilitate a "plug-in" design. The plug-in design reduces material costs and outage time required to complete the retrofit, compared to installing conventional, internally staged low-NO $\mathrm{N}_{\mathrm{x}}$ burners.

* The New Source Performance Standards (NSPS) require that the best demonstrated available control technology be used to satisfy requirements as set forth in Section III, Title 40 of the U.S. Code of Federal Regulations. 
The LNCB $^{\mathrm{TM}}$ was characterized in a laboratory test program in the early 1980 s. The test program indicated that the $\mathrm{LNCB}^{\mathrm{TM}}$ could maintain a stable flame throughout the operating range and that the expected $\mathrm{NO}_{\mathrm{x}}$ reduction would be in the order of $50 \%$.

In 1985, one two-nozzle cell burner was replaced with a $\mathrm{LNCB}^{\mathrm{TM}}$ at DP\&L's Stuart Station Unit No. 3 to test mechanical reliability. After three years of normal burner operation with no signs of material degradation, the test was deemed successful.

The full-scale LNCB ${ }^{\mathrm{TM}}$ project covered a 53-month span beginning in April 1990 and ending in August 1994.

Performance and emission tests were conducted before existing standard cell burners were retrofitted (Baseline Testing), and again after installation of the LNCB $^{\mathrm{TM}}$ (Optimized Testing). Emission tests were conducted by the Babcock \& Wilcox (B\&W) field testing department (Results) and by an unaffiliated testing company (Acurex). Results of these tests were compared and are summarized below. Mathematical combustion models developed at $\mathrm{B} \& \mathrm{~W}$ were very useful in arriving at an optimal $\mathrm{LCNB}^{\mathrm{TM}}$ configuration for testing. This is worth some discussion before comparing the baseline and optimized test measurements.

An extensive fundamental numerical modelling study of the fluid flow and combustion within the furnace was performed by $\mathrm{B} \& \mathrm{~W}$ to aid in the design of an optimal $\mathrm{LNCB}^{\mathrm{TM}}$ configuration to achieve the design objectives. In situ furnace measurements of gas temperature, gas velocity, and species were made in a plane located 40 feet above burner level, and at the furnace exit plane. This type of boiler data is very rare and provided a unique opportunity to calibrate the model at full scale. As a result, the agreement between model predictions and test measurements were generally very good. Therefore; B\&W's modelling capability provided a good tool for evaluating several $\mathrm{LCNB}^{\mathrm{TM}}$ firing configurations.

The initially installed $\mathrm{LNCB}^{\mathrm{TM}}$ configuration resulted in excessively high carbon monoxide $(\mathrm{CO})$ concentrations in the lower furnace. This condition was confirmed by both model results and actual test measurements. The high $\mathrm{CO}$ levels caused some concern regarding operational safety since the furnace is operated under positive pressure. For this reason, modelling efforts focused on evaluation of firing configurations which would alleviate high $\mathrm{CO}$ concentrations without significantly altering boiler performance. An optimal configuration was predicted to achieve these objectives, and testing eventually confirmed the modelling predictions. This provides support and justification for utilizing B\&W's modeling capabilities as a tool for effectively assessing the optimal $\mathrm{LCNB}^{\mathrm{TM}}$ firing configuration in future retrofit applications.

The average $\mathrm{NO}_{\mathrm{x}}$ emission rate for full-load operation with all mills in service was reduced by $55.5 \%$ for B\&W's data and $53.0 \%$ in accordance with Acurex data. The target reduction amount was $50 \% . \mathrm{NO}_{\mathrm{x}}$ emission rates per million Btu decreased with load as expected. More importantly, $\mathrm{NO}_{\mathrm{x}}$ reduction remained between $50 \%$ and $60 \%$ for most of the test cases run at different loads, excess airs, and burner configurations regardless of whether Acurex or B\&W collected the data. The two independent measurement techniques performed by each company agreed very well.

Significant discrepancies in the $\mathrm{CO}$ emissions during baseline testing were found between the Acurex and $\mathrm{B} \& \mathrm{~W}$ data. This was later attributed to the high $\mathrm{CO}$ span gas used in these tests. A third calibration gas much closer to the measurement range significantly reduced this discrepancy during post-retrofit testing. 
The uncertainty in the baseline measurements prevents an accurate comparison between baseline and post-retrofit $\mathrm{CO}$ measurements from being made. However, average $\mathrm{CO}$ emissions for the optimized $\mathrm{LNCB}^{\mathrm{TM}}$ firing configuration at full load with all mills in service were only $55 \mathrm{ppm}$ for B\&W's data and $28 \mathrm{ppm}$ for Acurex's data. These were the highest average values recorded for the two respective measurement techniques, and are within acceptable limits.

The furnace exit gas temperatures (FEGT) were analytically determined utilizing averaged sets of boiler operational data measured downstream of the furnace exit plane. This was considered more accurate than discrete high velocity thermocouple (HVT) measurements taken at the furnace exit plane. The FEGT showed a decrease of as much as $100^{\circ} \mathrm{F}$ during the early part of the optimized testing; however, as testing continued the FEGT increased to within $10^{\circ} \mathrm{F}$ of the baseline conditions.

The unburned carbon (UBC) loss generally increased by approximately $28 \%$ for all of the tests. The most significant increase from baseline data occurred for the test with one mill out of service, with an average loss of $0.69 \%$ in efficiency for a $52 \%$ increase in unburned carbon loss (see page A-3 for specific values of carbon-in-ash).

Boiler efficiency showed very little change from the baseline testing with the average for all mills in service increasing by $0.16 \%$. The UBC and CO emission losses increased, but were offset by the decrease in dry gas loss due to the lower economizer gas outlet temperature and the subsequent lower air heater gas outlet temperature. The higher post-retrofit efficiency may have also been partly due to the fact that coal fineness increased slightly due to pulverizer maintenance performed during the burner changeover. This would have the effect of making the UBC lower than it would have been if the coal coarseness were the same for both baseline and post-retrofit testing.

A test panel composed of several different types of commercially available coatings was installed in the burner zone of the furnace to determine the effects of flue gas emitted by the $\mathrm{LNCB}^{\mathrm{TM}}$ on tube materials. Preliminary analyses from destructively examining the furnace wall samples taken from the corrosion test panel show localized corrosion on the bare SA-213T2* tube material near the center of the panel. However, these corrosion rates are not significantly higher than those experienced in the original cell burner arrangement. These corrosion rates did not significantly increase even though the 15 -month test period for the corrosion testing included six months of operation with $\mathrm{LNCB}^{\mathrm{TM}}$ that were not optimally configured. This produced a more highly corrosive environment (high $\mathrm{H}_{2} \mathrm{~S}$ and $\mathrm{CO}$ ) in the vicinity of the tube panel. Furthermore, all of the other corrosion panel locations, from which SA-213T2 samples were taken, experienced no loss of thickness. The same is true for all the coated samples taken from all locations.

Analyses were performed on samples of ash collected during HVT testing. There was nothing found in analyses of the ash to indicate a significant difference from the ash samples collected during baseline testing. Based on the chemistry of the ash deposits, it is anticipated that ash deposition would not be a significant problem with either the standard cell burners or the $\mathrm{LNCB}^{\mathrm{TM}}$. This is also supported by the fact that calculated cleanliness factors for superheater, reheater, and economizer tube banks show little change from baseline to post-retrofit optimized testing. Furthermore, the small variations observed in the FEGT temperatures between baseline and optimized $\mathrm{LNCB}^{\mathrm{TM}}$ testing would indicate that little change in furnace slagging has occurred as a result of the retrofit.

\footnotetext{
* The furnace walls are constructed of SA-213T2 tube material.
} 
The independent testing laboratory (Acurex) conducted dust loading tests at the outlet of the economizer with EPA Method 17, and at the stack with EPA Method 5. Resultant precipitator efficiencies for full load with all mills in service, and full load with one mill out of service, decreased slightly by $0.13 \%$ and $0.37 \%$, respectively. Collection efficiencies were above $99 \%$ in all test cases.

LNCB $^{\mathrm{TM}}$ with sliding dampers provided individual combustion air control enabling the unit to operate at lower overall excess air levels.

Startup and turndown of the unit were unaffected by the conversion.

The low cost and short outage time for the retrofit make the design financially attractive when compared to a conventional low- $\mathrm{NO}_{\mathrm{x}}$ burner conversion. A conventional low- $\mathrm{NO}_{\mathrm{x}}$ conversion may require burner throat replacement and $\mathrm{NO}_{\mathrm{x}}$ port installation to achieve similar reduction results.

$\mathrm{LNCB}^{\mathrm{TM}}$ technology was specially developed as a low-cost $\mathrm{NO}_{\mathrm{x}}$ reduction option applicable to an existing class of coal-fired, base-loaded utility boilers which were originally equipped with high performance, but high $\mathrm{NO}_{\mathrm{x}}$ emitting "cell" burners. As such, it can only be viewed as a retrofit technology with costs which must be developed on a site-specific basis. Actual costs may vary significantly depending upon the initial condition of the boiler under consideration. In each retrofit, maximum use is made of existing components whenever possible to meet customer specific requirements at the lowest possible cost. The LNCB $^{\mathrm{TM}}$ concept was developed as a "plug-in" retrofit technology which does not require costly pressure part changes and minimizes other site modifications.

The economic analysis performed in this study (refer to Section 6) selected a $600 \mathrm{MWe}$ nominal unit size and a typical location in the midwest United States. A medium-sulfur, medium-volatile bituminous coal was chosen as the typical fuel.

The key capital costs of subsystems affected by the $\mathrm{LNCB}^{\mathrm{TM}}$ installation were developed (see Figure 6-2) and resulted in a total capital cost for the typical unit of $\$ 9 / \mathrm{kW}$ based on the assumptions of the analysis.

Projected operating and maintenance costs were also developed based on the sample $\mathrm{LNCB}^{\mathrm{TM}}$ retrofit noted above. These costs were approximately $\$ 300,000$ / year. Actual costs may be quite variable depending upon specific pre-retrofit conditions. If the unit is older and has not been significantly upgraded from its original combustion system hardware, it is possible to see no incremental operating costs.

The unit may actually experience a net credit for lower maintenance and improved boiler thermal efficiency.

Total costs (in constant 1994 dollars) for the commercial unit were $\$ 96.48$ per ton of $\mathrm{NO}_{\mathrm{x}}$ removed.

A brief review of the current cell burner boiler population indicates that these figures may be too conservative. An alternate scenario for the same unit might include the following:

- Furnace corrosion protection already used prior to retrofit (net $\$ 0 / \mathrm{kW}$ ).

- The combustion system and controls have already been upgraded (net $\$ 0 / \mathrm{kW}$ ).

- Unburned carbon loss changes little and is compensated for by lower $\mathrm{O}_{2}$ operation, less slagging, and lower air heater outlet temperature. 
The results are provided in the following summary on a constant-1994 dollar basis.

\section{Base Case}

Capital $(\$ / \mathrm{kW})$

(mills/kWh)

O\&M (mills/kWh)

Total (mills/kWh)

$\$ /$ ton $\mathrm{NO}_{\mathrm{x}}$ removed
9.00

0.196

0.088

0.284

96.48
Alternate Case

8.05

0.175

0.016

0.191

64.89

Based on the results of this demonstration project, the $\mathrm{LNCB}^{\mathrm{TM}}$ technology is a commercial success for the economical abatement of at least $50 \%$ of the $\mathrm{NO}_{\mathrm{x}}$ emissions from existing cell burner units. The low cost and short outage time for a $\mathrm{LNCB}^{\mathrm{TM}}$ retrofit make the design financially attractive for the cell burner boiler population. 


\section{CONTENTS}

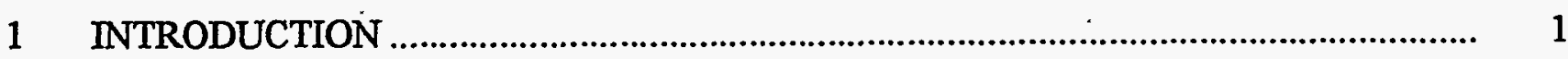

1.1 Background ...................................................................................................

1.2 Description of Low-NO ${ }_{x}$ Cell $^{\mathrm{TM}}$ Burner Technology ..................................................... 2

1.3 Previous Work Relevant to the CCT-III Project............................................................. 3

1.4 Host Site Characteristics .........................................................................................

1.5 Project Organization ....................................................................................... 7

1.6 Project Phases .............................................................................................................. 7

1.7 Major Program Activities ....................................................................................... 8

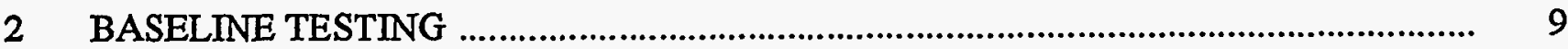

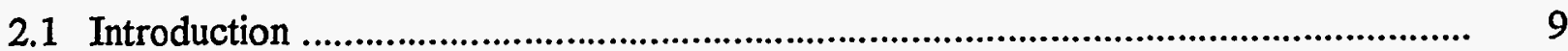

2.2 Environmental Effects of Standard Cell Burners ...................................................... 10

$2.2 .1 \mathrm{NO}_{\mathrm{x}}$ Emissions ....................................................................................... 10

2.2.2 CO Emissions ....................................................................................... 11

$2.2 .3 \quad \mathrm{H}_{2} \mathrm{~S}$ Measurements ................................................................................ 11

2.2.4 Particulate Emissions ............................................................................ 11

2.2.5 Boiler Flyash ....................................................................................... 12

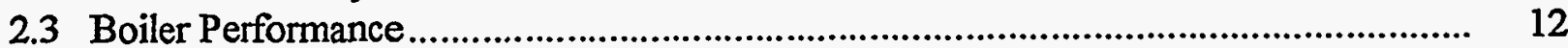

2.3.1 Superheater/Reheater Steam Temperature Control ............................................ 15

2.3.2 Furnace Exit Gas Temperature (FEGT) ..................................................... 15

2.3.3 Surface Cleanliness ............................................................................... 15

2.3.4 Unburned Carbon Loss ........................................................................... 16

2.3.5 Efficiency Calculations ................................................................................... 16

2.3.6 Coal Fineness ....................................................................................... 17

3 NUMERICAL FLOW AND COMBUSTION MODELING ........................................... 18

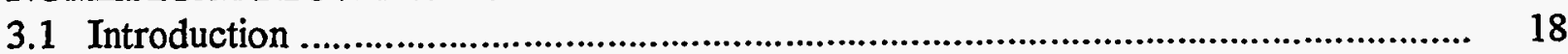

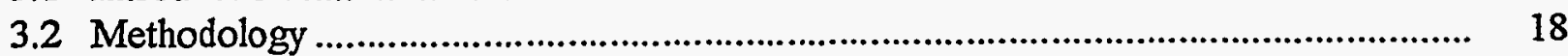

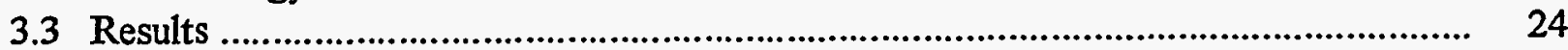

3.3.1 CO Mitigation .......................................................................................... 24

3.3.2 Furnace Exit Gas Temperature (FEGT) .......................................................... 24

3.3.3 Comparison With Data................................................................................. 25

3.3.4 Gas Velocity Magnitudes ............................................................................ 28

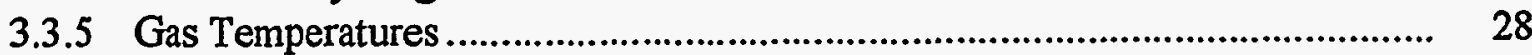

3.3.6 Oxygen Concentrations .................................................................... 28

3.3.7 Carbon Monoxide Concentrations ................................................................. 28 


\section{CONTENTS (Continued)}

Section

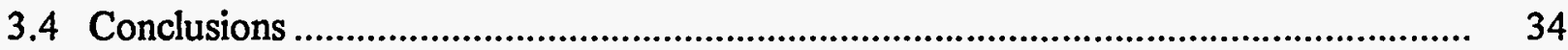

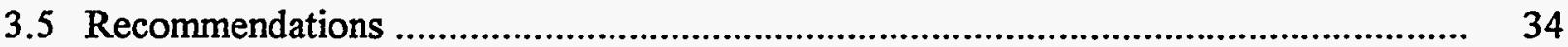

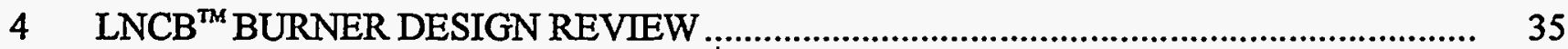

4.1 Low-NO Cell $^{\text {TM }}$ Burner Hardware .................................................................... 35

4.2 Mechanical Modifications ................................................................................... 35

4.2.1 Implementation of Mathematical Modeling ............................................... 36

4.2.2 Modeling Summary ............................................................................ 41

4.3 Control System Modifications .................................................................................. 41

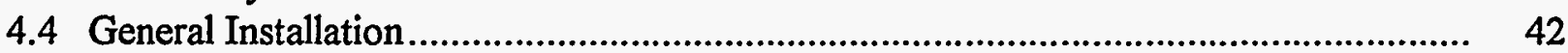

4.4.1 Pre-Outage Work ......................................................................... 42

4.4.2 Outage and Post-Outage Work ….......................................................... 42

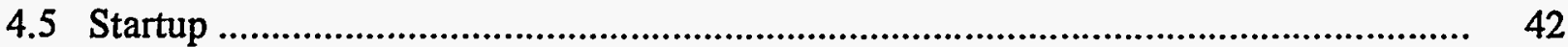

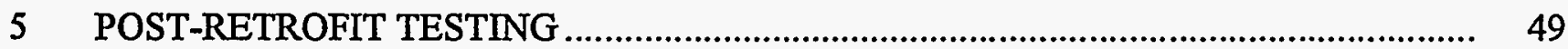

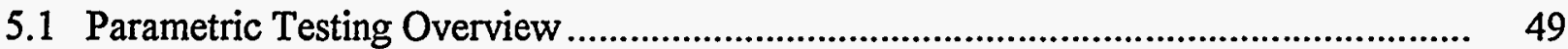

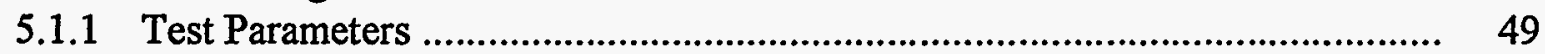

5.1.2 Boiler Performance Characterization ........................................................ 49

5.1.3 Continuous Emissions Monitoring Results................................................. 51

5.2 Optimization Testing ........................................................................................... 52

5.2 .1 Test Conditions ............................................................................... 52

5.2.2 Evaluation Methodology ................................................................... 54

5.2.3 Environmental Effects of Low- $\mathrm{NO}_{\mathrm{x}} \mathrm{Cell}^{\mathrm{MM}}$ Burner ........................................ 54

5.2.4 Boiler Performance ................................................................................ 67

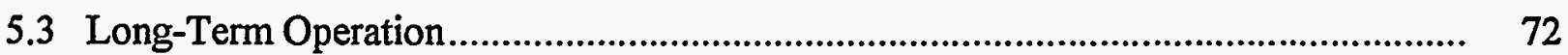

5.3.1 Operating Experience ................................................................................. 73

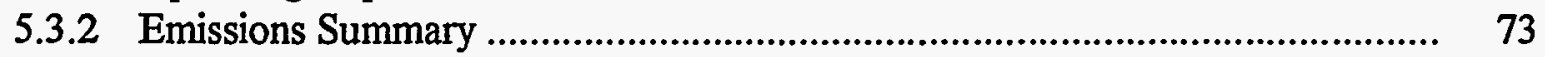

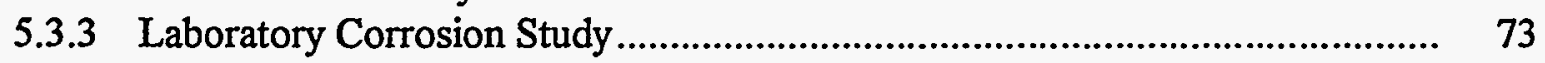

5.3.4 Field Corrosion Study .......................................................................... 76

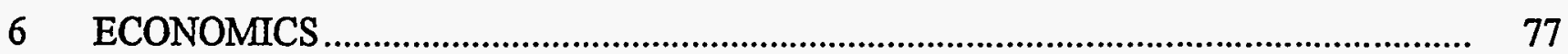

6.1 Economic Parameters ........................................................................................ 77

6.1.1 Unit Size, Location, and Fuel .............................................................. 77

6.1.2 Other Assumptions ............................................................................ 78

6.2 Estimated Process Capital Costs ........................................................................... 78

6.2.1 Key Capital Cost Subsystems ............................................................... $\quad 78$

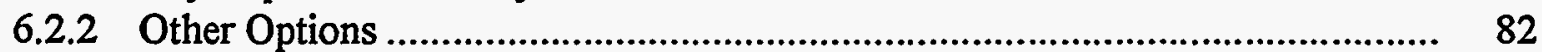

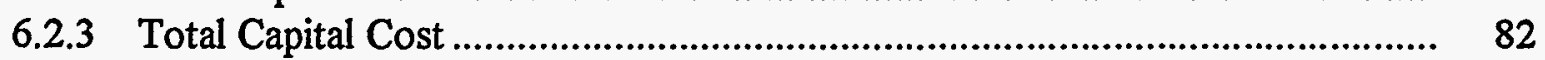

6.3 Projected Operating and Maintenance Costs .......................................................... 83

6.3.1 Fixed Operating and Maintenance Costs .................................................... 83

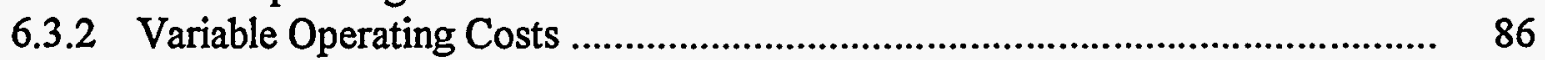

6.4 Summary of Performance and Economics ................................................................. 86 


\section{CONTENTS (Continued)}

Section

7 COMMERCIALIZATION POTENTIAL AND PLANS .................................................. 89

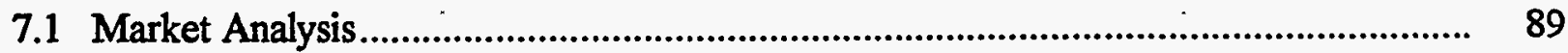

7.1.1 Application of the Technology .................................................................... 89

7.1.2 Market Size ....................................................................................................... 91

7.1.3 Market Barriers........................................................................................... 91

7.1.4 Economic Comparison With Competing Technologies .................................... 91

7.2 Commercialization Plans .............................................................................................. 92

7.2.1 Commercialization of the LNCB ${ }^{\mathrm{TM}}$ Technology ................................................ 92

Appendix A ENVIRONMENTAL IMPACTS 


\section{ILLUSTRATIONS}

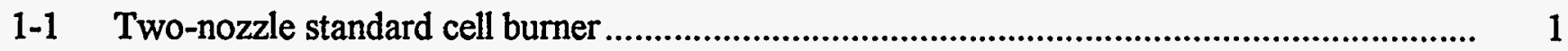

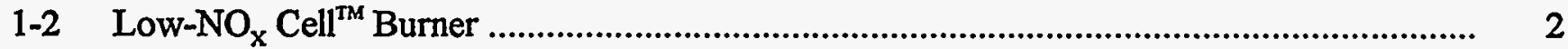

1-3 Initial burner and $\mathrm{NO}_{\mathrm{x}}$ port locations ............................................................................... 4

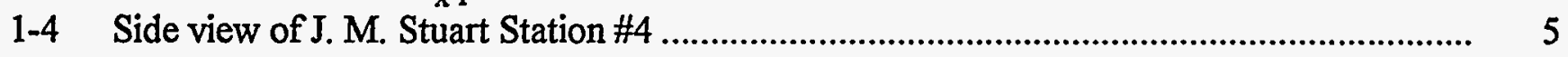

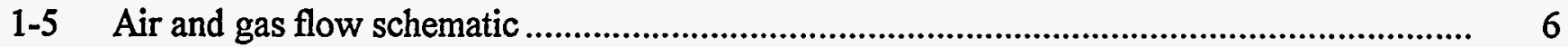

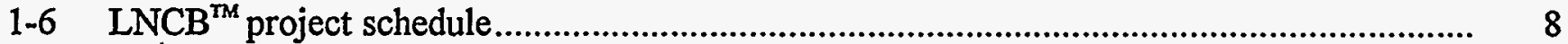

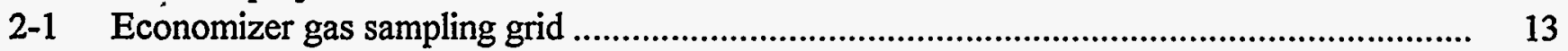

2-2 Airheater gas sampling grid ....................................................................................... 13

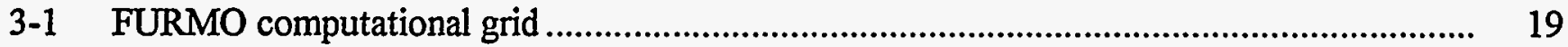

3-2 Arrangement and swirl pattern of standard cell burners ..................................................... 22

3-3 Post-retrofit arrangement of burners and air ports ........................................................... 23

3-4 Predicted furnace exit gas temperatures ........................................................................ 25

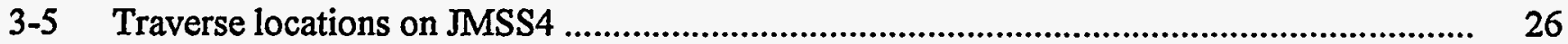

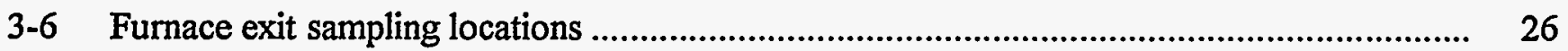

3-7 Sampling locations at a plane 40 feet above the burners .................................................. 27

3-8 CO concentrations for full load -40 feet above the burners ........................................... 30

3-9 CO concentrations for full load — furnace exit ............................................................. 31

3-10 CO concentrations for intermediate load -40 feet above the burners ............................. 32

3-11 CO concentrations for intermediate load — furnace exit ............................................... 33

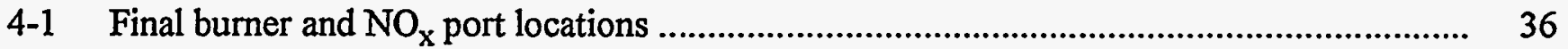

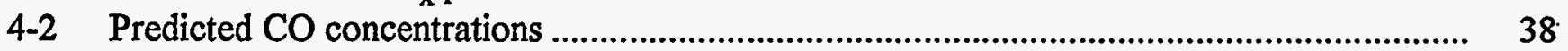

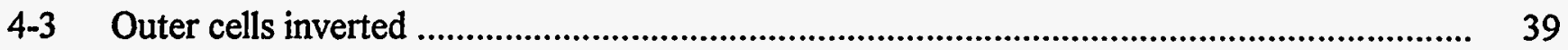

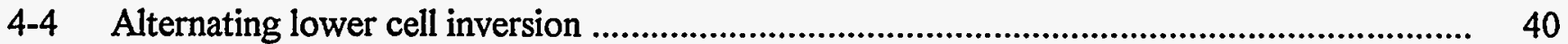

4-5 Pre-retrofit photograph of a standard two-cell burner ...................................................... 44

4-6 An original cell burner as seen from the burner ............................................................. 44

4-7 The burner portion of a LNCB $^{\mathrm{TM}}$ burner lies in the laydown yard prior to installation ........... 45

4-8 A louvered $\mathrm{NO}_{\mathrm{x}}$ port is rigged for installation above the burner ........................................ 45

4-9 The burner portion of the $\mathrm{LNCB}^{\mathrm{TM}}$ burner is hoisted into place ........................................ 46

4-10 A ceramic-lined coal elbow is installed on the burner front................................................. 46

4-11 An installed ceramic-lined Y-pipe combines two of the original coal lines ............................ 47

4-12 A completed $\mathrm{LNCB}^{\mathrm{TM}}$ burner as viewed from the burner platform .................................... 47

4-13 A wall of $L N C B^{T M}$ burners viewed from inside the furnace prior to inversion of every other lower level burner and $\mathrm{NO}_{\mathrm{x}}$ port......................................................................... 48

5-1 $\quad \mathrm{NO}_{\mathrm{x}}$ emissions versus unit output at full load - $\mathrm{B} \& \mathrm{~W}$ data ............................................ 56

5-2 $\quad \mathrm{NO}_{\mathrm{x}}$ emissions versus unit output at full load - Acurex data ...................................... 56

5-3 $\quad \mathrm{NO}_{\mathrm{x}}$ emissions versus unit output at intermediate and low load - B\&W data ................... 57

5-4 $\quad \mathrm{NO}_{\mathrm{x}}$ emissions versus unit output at intermediate and low load - Acurex data .................. 57 


\section{ILLUSTRATIONS (Continued)}

Figure

5-5 $\quad \mathrm{NO}_{\mathrm{x}}$ emissions versus excess air at full load — B\&W data .................................................. 58

5-6 $\quad \mathrm{NO}_{\mathrm{x}}$ emissions versus excess air at full load - Acurex data ................................................ 58

5-7 $\quad \mathrm{NO}_{\mathrm{x}}$ emissions versus excess air at intermediate and low load - B\&W data ....................... 59

5-8 $\mathrm{NO}_{\mathrm{x}}$ emissions versus excess air at intermediate and low load - Acurex data ..................... 59

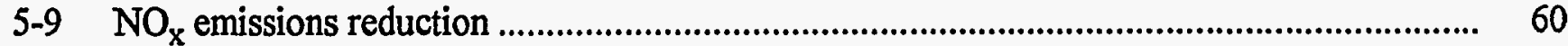

5-10 CO emissions versus unit output at full load - B\&W data .................................................... 61

5-11 CO emissions versus unit output at full load - Acurex data ................................................... 61

5-12 CO emissions versus unit output at intermediate and low load - B\&W data ......................... 62

5-13 CO emissions versus unit output at intermediate and low load - Acurex data ..................... 62

5-14 CO emissions versus excess air at full load - B\&W data ................................................... 63

5-15 CO emissions versus excess air at full load - Acurex data ................................................. 63

5-16 CO emissions versus excess air at intermediate and low load — B\&W data ........................... 64

5-17 CO emissions versus excess air at intermediate and low load - Acurex data ......................... 64

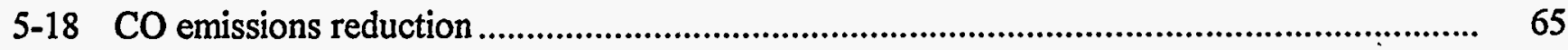

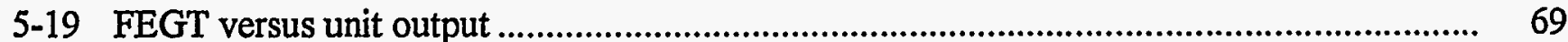

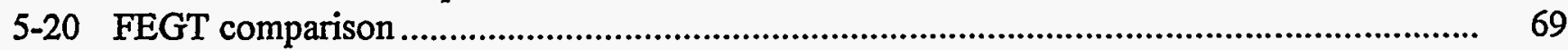

5-21 Secondary superheater $\mathrm{K}_{\mathrm{f}}$ comparison .......................................................................... 71

5-22 Reheater, primary $\mathrm{SH}$, and economizer $\mathrm{K}_{\mathrm{f}}$ comparison ..................................................... 71

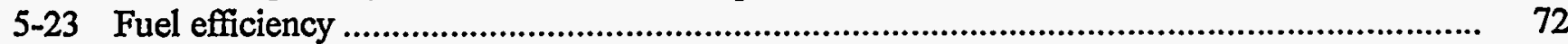

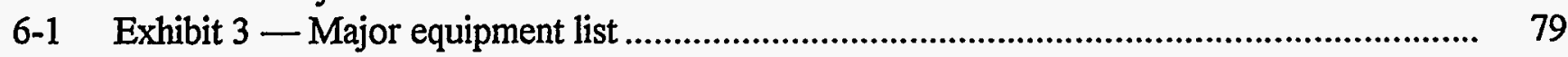

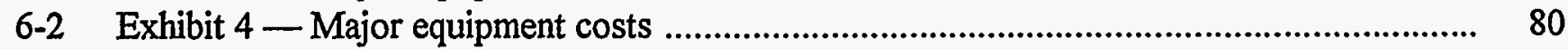

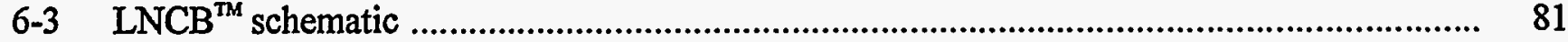

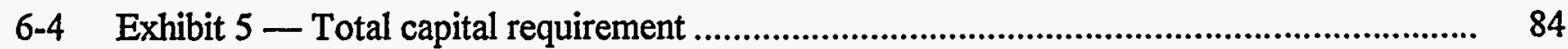

6-5 Exhibit 6 - Operating and maintenance cost........................................................... 85

6-6 Exhibit 7 - Summary of performance and cost data ....................................................... 87 


\section{TABLES}

\section{Table}

3-1 Numerically Modeled Operating Conditions

4-1 Actual Timeline of $\mathrm{LNCB}^{\mathrm{TM}}$ Installation ..................................................................... 43

5-1 Parametric Testing Results ................................................................................................ 50

5-2 Chronological Listing of Optimized Tests .......................................................................... 53

5-3 Precipitator Performance ................................................................................................... 67

5-4 Long-Term Emissions Data — Full Load With All Mills in Service...................................... 74

5-5 Long-Term Emissions Data — Full Load With One Mill Out of Service ............................ 74

7-1 Market Summary ………............................................................................................. 91

7-2 Comparison Matrix — Typically 300 MWe Plant ........................................................... 92 


\section{Section 1 \\ INTRODUCTION}

\subsection{Background}

Economic considerations, which dominated boiler design during the 1960 s, have led to the development of cell burners for achieving a high boiler efficiency. Each "cell" consists of two or three circular burner throats mounted in close proximity to each other in the lower furnace. A standard two-nozzle cell burner is shown in Figure 1-1.

Cell burners are designed for rapid mixing of fuel and air to achieve high combustion temperatures. The tight burner spacing and rapid fuel/air mixing minimizes flame size while maximizing heat release rates and overall unit efficiency. However, the rapid heat release produces relatively high $\mathrm{NO}_{\mathrm{x}}$ concentrations in the combustion gases. Typically, the $\mathrm{NO}_{\mathrm{x}}$ levels associated with the standard cell burners range from 1.0 to $1.8 \mathrm{lbm}$ of $\mathrm{NO}_{\mathrm{x}}$ as $\mathrm{NO}_{2}$ per $10^{6} \mathrm{Btu}$ heat input.

The "Full-Scale Demonstration of Low-NO ${ }_{x}$ Cell $^{\text {TM }}$ Burner Retrofit" is one of the U.S. Department of Energy (DOE) Clean Coal Technology Phase III (CCT-III) Demonstration projects. The primary objective of the LNCB $^{\mathrm{TM}}$ demonstration program is to evaluate the applicability of the $\mathrm{LNCB}^{\mathrm{TM}}$ combustion technology for reducing the $\mathrm{NO}_{\mathrm{x}}$ emissions in a full-scale utility boiler equipped with standard cell burners. Specific program objectives include:

- Achieve at least a $50 \%$ reduction in $\mathrm{NO}_{\mathrm{x}}$ emissions.

- Reduce $\mathrm{NO}_{\mathrm{x}}$ with no degradation to boiler performance or life.

- Demonstrate a technically and economically feasible retrofit technology.

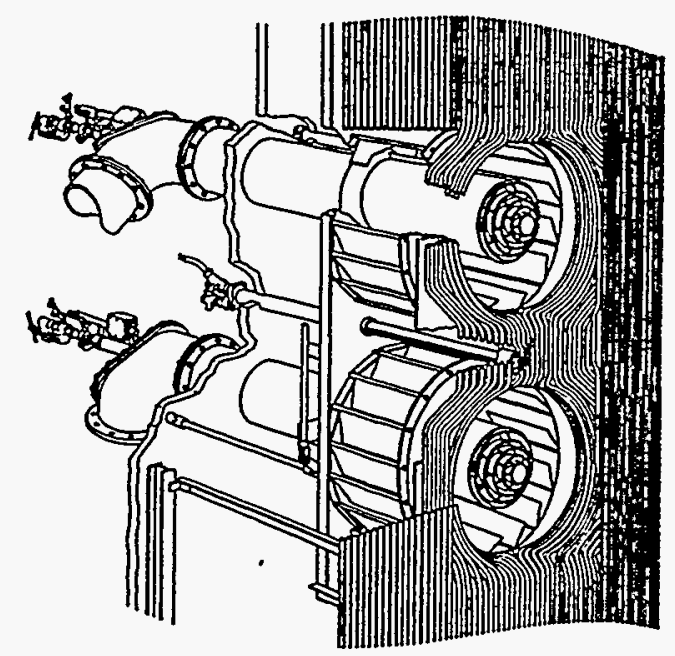

Figure 1-1 Two-nozzle standard cell burner 
To reduce the $\mathrm{NO}_{\mathrm{x}}$ emissions, the LNCB ${ }^{\mathrm{TM}}$ burners are designed to stage the mixing of fuel and combustion air. While the delayed fuel/air mixing is effective in suppressing $\mathrm{NO}_{\mathrm{x}}$ formation, the burners are also designed to facilitate a "plug-in" replacement of the original cell burners so that no pressure part modifications are required. The plug-in design can significantly reduce the materials cost and outage time associated with a $\mathrm{LNCB}^{\mathrm{TM}}$ retrofit compared to the installation of other types of internally staged low$\mathrm{NO}_{x}$ burners.

The LNCB ${ }^{\mathrm{TM}}$ burner demonstration commenced in April 1990 and completed in August 1994, covering a total of 53-month program span.

\subsection{Description of Low-NO Cell $^{\mathrm{TM}}$ Burner Technology}

$\mathrm{LNCB}^{\mathrm{TM}}$ burners, as shown in Figure 1-2, were developed by Babcock \& Wilcox $(\mathrm{B} \& \mathrm{~W})$ in association with the Electric Power Research Institute (EPRD) to minimize the formation of thermal and fuel $\mathrm{NO}_{\mathrm{x}}$. More than $75 \%$ of the $\mathrm{NO}_{\mathrm{x}}$ formed during firing of conventional pulverized coal is fuel $\mathrm{NO}_{\mathrm{x}}$; the remainder is thermal $\mathrm{NO}_{\mathrm{x}}$. Consequently, the most effective combustion countermeasures are those limiting the fuel $\mathrm{NO}_{\mathrm{x}}$ formation.

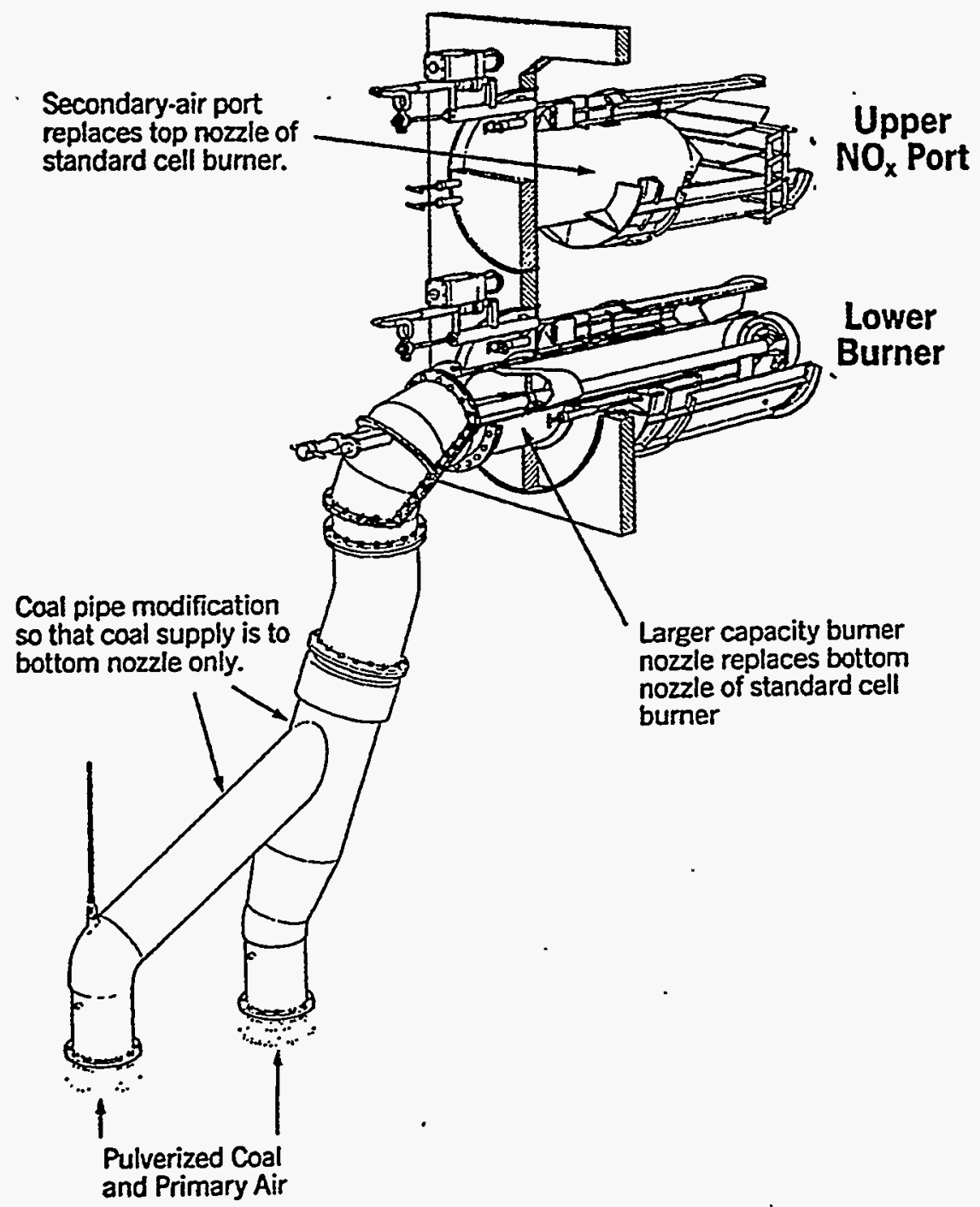

Figure 1-2 Low-NO Cell $^{\mathrm{TM}}$ Burner 
Fuel $\mathrm{NO}_{\mathrm{x}}$ is formed by oxidation of fuel-bound nitrogen during devolatilization and char burnout. Coal typically contains 0.5 to $2.0 \%$ nitrogen bound in its organic matter. High oxygen availability and flame temperatures during devolatilization promote the conversion of volatile-released nitrogen to $\mathrm{NO}_{\mathrm{x}}$. Nitrogen retained in the char has a lower conversion efficiency to $\mathrm{NO}_{\mathrm{x}}$, primarily due to lower oxygen availability during the char burnout process.

Therefore, the most effective means for fuel $\mathrm{NO}_{\mathrm{x}}$ reduction is to minimize the availability of oxygen in air during the critical step of devolatilization. Additional air can be added later to complete the char burnout process and still maintain high combustion efficiency.

The approach of $\mathrm{LNCB}^{\mathrm{TM}}$ burners in reducing the fuel $\mathrm{NO}_{\mathrm{x}}$ formation involves replacing one of the original circular burners in each cell with an S-type circular burner and the other with a secondary air injection port (i.e., a NO $\mathrm{No}_{\mathrm{x}}$ port). The flame is shaped by 1 ) an impeller mounted at the exit of the coal pipe and 2) adjustable spin vanes in the secondary air zone of the S-burner. The $\mathrm{NO}_{\mathrm{x}}$ port louver dampers provide additional control over the mixing of fuel and air streams. The S-burner operates at a low airfuel stoichiometry, typically $60 \%$ of the required theoretical air required for complete combustion. The balance of the air enters through the adjacent $\mathrm{NO}_{\mathrm{x}}$ port.

\subsection{Previous Work Relevant to the CCT-III Project}

A series of test programs have been performed to fully characterize the $\mathrm{LNCB}^{\mathrm{TM}}$ burners at several developmental scales, i.e., $1.75 \mathrm{MWe}, 30 \mathrm{MWe}$, and full utility scale. The primary purposes of these programs were to evaluate the performance of $\mathrm{LNCB}^{\mathrm{TM}}$ burners on $\mathrm{NO}_{\mathrm{x}}$ reduction, unburned carbon (UBC) loss, corrosion, carbon monoxide (CO), and impact to furnace exit gas temperature (FEGT). Results from the laboratory and pilot-scale studies showed that 1) the $\mathrm{LNCB}^{\mathrm{TM}}$ arrangement was stable over the designed burner operating range and 2) a greater than $50 \% \mathrm{NO}_{\mathrm{x}}$ reduction was achievable with acceptable impacts on CO, UBC, and FEGT levels in boilers.

In 1985, one of the 24 standard two-nozzle cell burners in Unit \#3 of the J. M. Stuart Station of Dayton Power \& Light (DP\&L) was replaced with a $\mathrm{LNCB}^{\mathrm{TM}}$ burner. The replacement was to evaluate the longterm mechanical reliability of $\mathrm{LNCB}^{\mathrm{TM}}$ burners. The design of Unit \#3 is identical to that of Unit \#4 used as the host site for the CCT-III program. After three years of normal burner operation in Unit \#3 with no signs of material degradation, the reliability test of the single $\mathrm{LNCB}^{\mathrm{TM}}$ burner was successfully concluded.

The full-scale retrofit of $L N C B^{\mathrm{TM}}$ equipment at JMSS4 (J. M. Stuart Station \#4) was completed during a six-week scheduled turbine outage from October - November 1991. To evaluate the long-term corrosion effects from the burner retrofit, a corrosion test panel was installed on the west side wall in the burner zone, and ultrasonic thickness (UT) measurements were performed on several sandblasted areas on the lower furnace walls. The initially designed $\mathrm{LNCB}^{\mathrm{TM}}$ arrangement for $\mathrm{JMSS} 4$, which replicated the pilot scale optimized arrangement, is shown in Figure 1-3. However, cell inversion of some $\mathrm{LNCB}^{\mathrm{TM}}$ burners in the lower row was necessary to reduce the high $\mathrm{CO}$ concentration in the hopper. This new burner arrangement will be discussed in Section 4. 


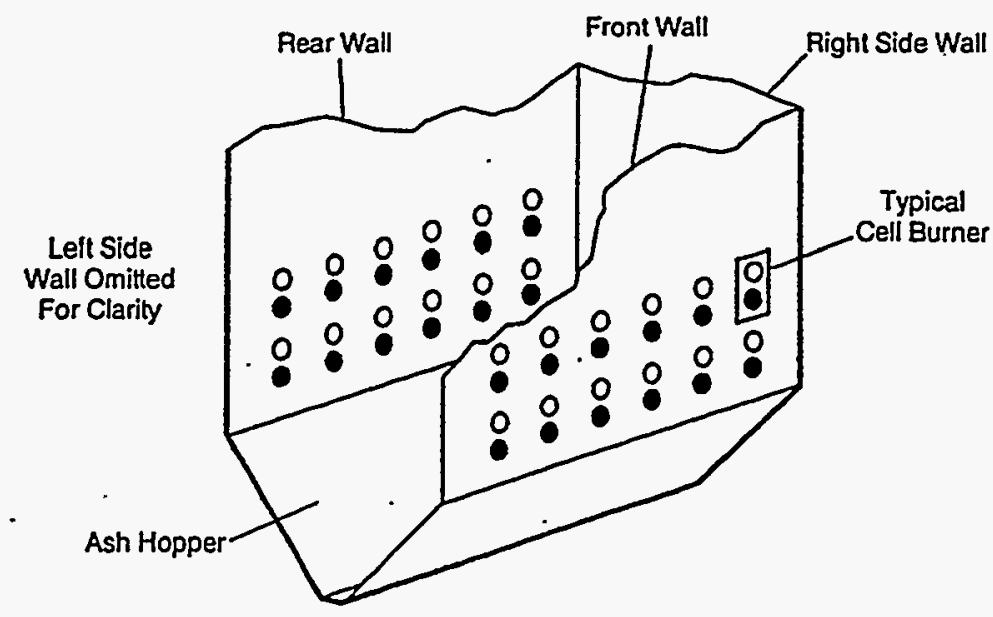

\section{Original LNCB ${ }^{\text {mi }}$ Arrangement}

$\mathrm{ONO}_{x}$ Overfire Air Port

- Burner

Figure 1-3 Initial burner and $\mathrm{NO}_{\mathrm{x}}$ port locations

\subsection{Host Site Characteristics}

DP\&L offered use of JMSS4 as the host site for the full-scale $\mathrm{LNCB}^{\mathrm{TM}}$ demonstration program. JMSS4 is a PC-fired supercritical single-reheat Carolina-type boiler. The furnace has a hopper bottom and a 10foot furnace arch on the rear wall beneath the secondary superheater platens. The furnace is 63 feet wide (side wall to side wall), 39 feet deep (front wall to rear wall), and 156 feet tall (bottom-most header to top-most header). The unit is of typical B\&W designs in the mid 1960s to early 1970 s. The original $\mathrm{B} \& W$ contract number is UP-106.

JMSS4 is rated at $4400 \mathrm{klbs} / \mathrm{hr}$ main steam flow with a superheater outlet steam pressure of $3805 \mathrm{psig}$ at $1005^{\circ} \mathrm{F}$, and a reheater steam flow of $3575 \mathrm{klbs} / \mathrm{hr}$ and reheater steam pressure of $650 \mathrm{psig}$ at $1005^{\circ} \mathrm{F}$. These conditions allow for a design output of $605 \mathrm{MWe}$ from the General Electric steam turbine. Figure 1-4 is a side view of the unit, which depicts most of the major components.

The unit is equipped with six B\&W MPS-89K coal pulverizers, each feeding four standard cell burners (two coal nozzles per cell) for a total of 48 burner nozzles. Each pulverizer is rated at $108 \mathrm{klbs} / \mathrm{hr}$ coal flow for coal with a Hardgrove Grindability Index (HGI) of 50. The pulverizers were designed to grind the coal to a fineness of $\sim 70 \%$ passing through a 200 USS mesh screen.

JMSS4 was originally equipped with 24 standard cell burners, each having two 15 -inch ID coal nozzles per cell. The nozzles serve as coal line terminations which admit a mixture of pulverized coal and primary air into the furnace envelope. The standard cells were arranged for opposed wall firing. in JMSS4 so that the opposite flames emitting from the front and back walls were aimed at each other. 


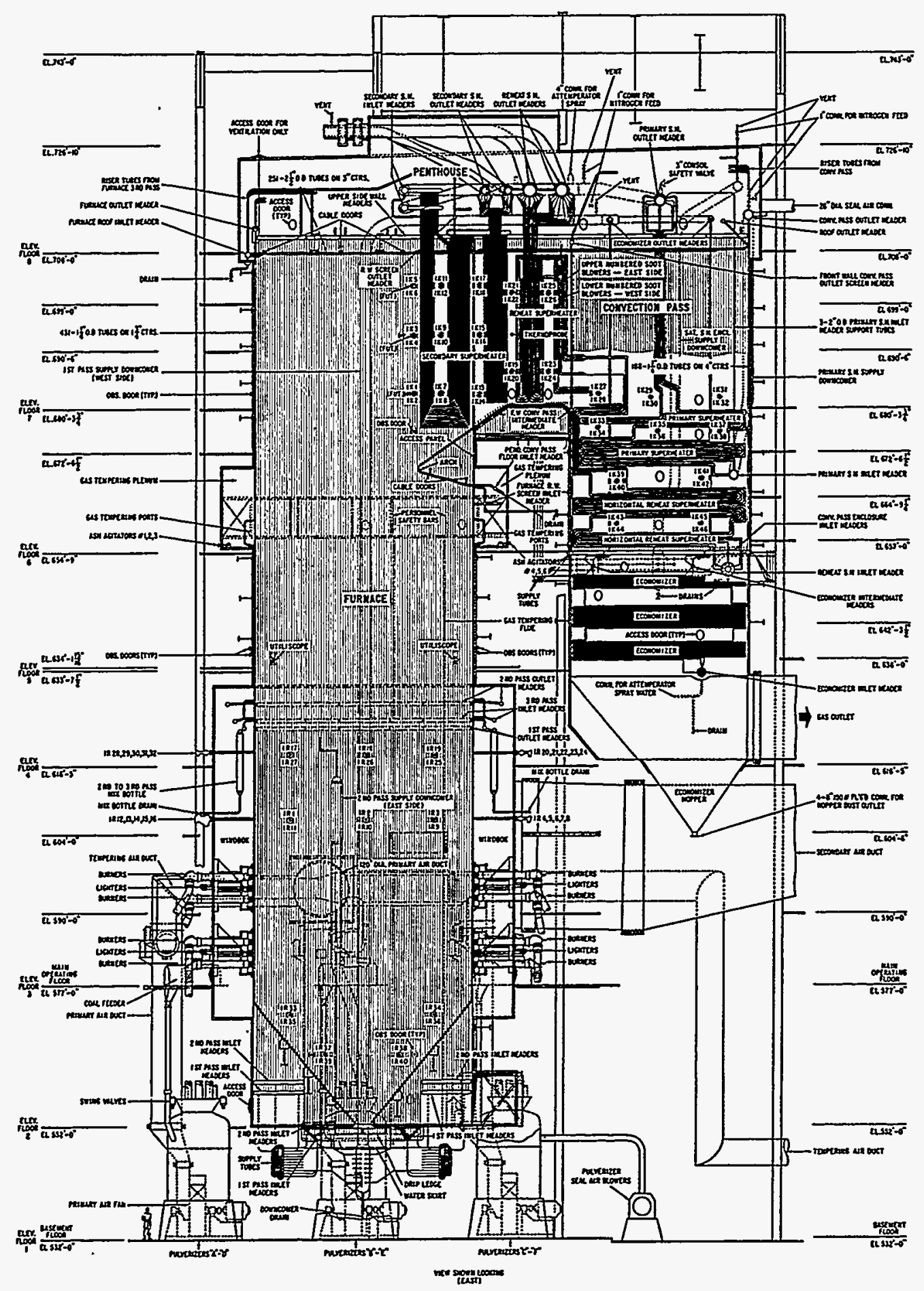

Figure 1-4 Side view of J. M. Stuart Station \#4 
Primary air, used to dry and transport the coal, is supplied to each pulverizer by a hot primary air (PA) fan. The primary air entering the PA fans is a mixture of 1) hot air from a wrap-around windbox and 2) cooler tempering air from a takeoff downstream of the glycol air preheater. The proportions of hot and tempering air are controlled to maintain a fixed mill outlet temperature, while total flow is controlled relative to the coal flow rate to maintain a preset fuel-air ratio.

Combustion air is supplied to the unit from two forced draft (FD) fans operating in parallel. The air is preheated by a glycol coil preheater followed by a regenerative airheater. The air flow path splits after leaving the regenerative airheater. The primary air's pressure is boosted by the PA fan to overcome mill and coal line losses while transporting the pulverized coal to the burner nozzles. Secondary air flows to the wrap-around windbox that contains the 24 cell burners, entering the furnace through the secondary air zone of each burner. Figure 1-5 is a schematic of the air and gas streams for this unit.

Secondary air is delivered to the front and rear wall wind boxes where it enters the furnace through the secondary air zone of each burner. After combustion is completed in the burner zone, the flue gas travels upward where it enters the pendant convection pass after a $90^{\circ}$ turn. The flue gas passes through the secondary superheater and reheater outlet banks before turning $90^{\circ}$ and passing downward through the primary superheater, the reheater, and the economizer. After leaving the economizer, the flue gas flows through the regenerative airheater and followed by the electrostatic precipitator (ESP) and finally up the stack.

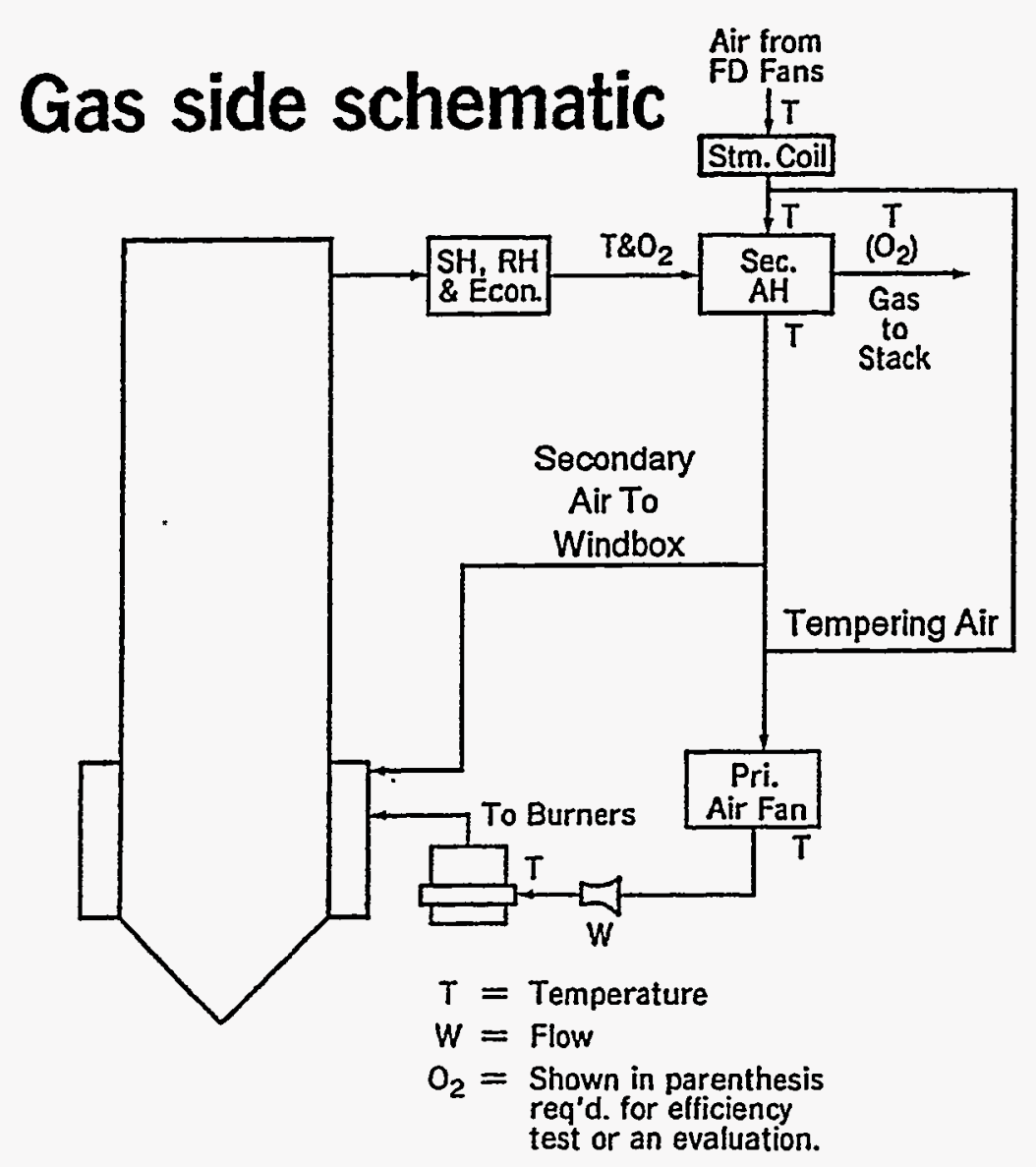

Figure 1-5 Air and gas flow schematic 
The boiler has a fluid flow design in which feedwater enters the lower header of the economizer and flows upward in parallel paths to the outlet headers. After flowing through stringers supporting the reheaters, it is distributed by a pipe system to the UP furnace first pass inlet headers. From the lower furnace first pass inlet headers, the fluid flows vertically through alternate tubes to just above the burner zone, where it is mixed and routed to the lower furnace second pass inlet headers. After flowing upward through alternate lower furnace tubes, the fluid is again mixed above the burner zone and distributed to the third level vertical pass, consisting of the entire upper furnace periphery.

From the furnace enclosure steam flows through the roof, convection pass enclosure, horizontal primary superheater, furnace wings, and two pendant superheater stages. Attemperators are deployed upstream of the final (secondary) superheater section for control of main steam temperature transients. The highpressure reheater consists of two heat transfer sections with an attemperator between the sections. The low-pressure reheater is a single-stage design with an attemperator at the inlet.

\subsection{Project Organization}

The program team is comprised of the following organizations:

- Department of Energy (DOE)

- Babcock \& Wilcox (B\&W)

- Dayton Power \& Light (DP\&L)

- Electric Power Research Institute (EPRI)

- State of Ohio Coal Development Office (OCDO)

- Utility funding co-sponsors:

- Allegheny Power System

- Centerior Energy

- Duke Power Company

- New England Power Company

- Tennessee Valley Authority

- Cincinnati Gas \& Electric Company

- Columbus and Southern Power Company

- Acurex Environmental Corporation (Acurex)
- Funding co-sponsor

- Prime contractor, project manager and funding co-sponsor

- Host site utility, operations and construction management and funding co-sponsor

- Testing consultant and funding co-sponsor

- Funding co-sponsor

\subsection{Project Phases}

The original project schedule and breakdown proposed for the major phases and tasks are shown in Figure 1-7.

The key milestone completion dates are listed below.

- Design Engineering

- Pre-Retrofit Testing

- Installation of Equipment

- Optimization Testing

- Long-Term Testing

- Final Report
April 1, 1990

November 8, 1990

November 2, 1991

June 30, 1992

April 20, 1994

August 31, 1994

- Testing subcontractor to $B \& W$ 


\subsection{Major Program Activities}

The baseline testing was began in October 1990 and completed in November 1990. This testing provided JMSS4 baseline performance and emission data for later comparison to the post-retrofit data. A final Baseline Testing Report was issued.

The parametric testing was conducted in May 1992 after the $\mathrm{LNCB}^{\mathrm{TM}}$ burners were installed at JMSS4 to determine the optimum burner settings for the final burner arrangement.

The optimization testing was performed in June 1992, which recorded the performance and emission levels of the unit under the operation of $\mathrm{LNCB}^{\mathrm{TM}}$ burners at optimum burner settings. Load and excess air tests identical to those performed in the baseline testing were repeated during the optimization testing.

The long-term testing began in August 1992 using Acurex's continuous emissions monitoring (CEM) equipment and continued until JMSS4's next major scheduled outage in April 1993. Prior to the 1993 outage, B\&W conducted in-furnace gas probing in August 1992 and March 1993 to determine the $\mathrm{H}_{2} \mathrm{~S}$ concentrations of the furnace gases along the front wall and side walls of the unit in the vicinity of the burner zone. After 15 months of $\mathrm{LNCB}^{\mathrm{TM}}$ operation, tube samples were removed from the corrosion test panel to evaluate the extent of furnace wall wastage. In addition, UT measurements were conducted to document the remaining tube thicknesses of several sandblasted furnace wall areas. Results of the longterm testing are described later in Section 5.

Phase l: Desizn
Test Plan Development
Pre-retrofit Testing
Design Engineering
Phase IIA: Procurement \& Fabrication
Procurement
Manulacturing \& Fabrication
Phase IlB: Installation
Pre-outage Construction
Installation of Equipment
Startup \& Shakedown
Phase IIl: Operalion
Preliminary Testing
Parametric \& Optimization Testing
Long Term Testing
Final Report

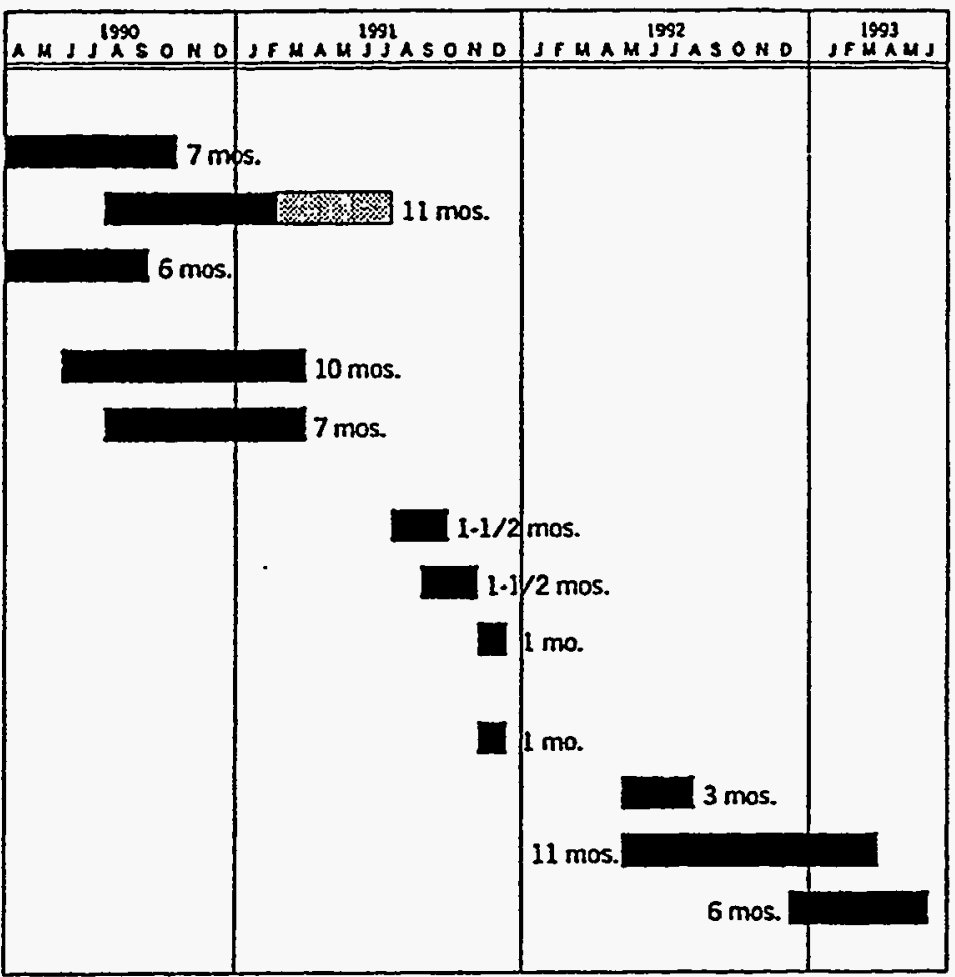

落 Represents Lubaralory Testing

Figure 1-7 LNCB $^{\mathrm{TM}}$ project schedule 


\section{Section 2 \\ BASELINE TESTING}

\subsection{Introduction}

The purpose of the baseline testing was to establish a performance benchmark prior to installation of the $\mathrm{LNCB}^{\mathrm{TM}}$ so post-retrofit comparisons could be made. This study included boiler efficiency, gaseous emissions, particulate loading, and the performance of various heat transfer components of J. M. Stuart Station \#4 (JMSS4).

The testing methods and procedures employed were carefully chosen to produce improved accuracy of data in unit performance, gaseous emissions, and particulate matter emissions. These methods and procedures have been described in a previously issued report, Project Test Plan for Full-Scale Demonstration of Low-NO ${ }_{x}$ Cell Burner Retrofit.

The collected test data can be generalized into three groups:

- Operational Performance

- Gaseous and Particulate Matter Emissions

- Furnace Probing for Temperatures, Velocities, and Flue Gas Composition

The operational performance data were collected by a computerized data acquisition system developed by Babcock \& Wilcox (B\&W). Data from plant instrumentation were collected every minute, and those from temporary test instrumentation were taken every five minutes. These data were then averaged in every 10 minutes and stored on a computer disk at JMSS4. The stored averaged data were later analyzed on an incremental basis by another computer system, known as the Boiler Performance Diagnostic System-140 (BPD). Using this system, the performance of unit efficiency, output, fuel flow, gas weights, heat transfer, and furnace exit gas temperature (FEGT) were calculated.

Temporary gas sampling grids were installed at the airheater inlet and outlet to determine the excess air and airheater leakage for calculating the unit efficiency. The efficiency calculations will be described later in this section.

The collection of gaseous and particulate matter emissions were performed by the subcontractor, Acurex Corporation. The methods and procedures were described in the Project Test Plan report. The continuous emissions monitoring (CEM) system used was capable of measuring $\mathrm{NO}, \mathrm{NO}_{2}, \mathrm{CO}, \mathrm{CO}_{2}, \mathrm{O}_{2}$, and total hydrodarbons (THC) at each sampling point located at the airheater outlet. For the particulate mass loading, EPA Method 17 was used to analyze the gas samples collected at the economizer outlet. Selected samples were analyzed for their carbon content, particle size distributions, fly ash resistivities, and losses on ignition (LOI). Particulate loading was also conducted at the stack using EPA Method 5 to determine the ESP efficiency. 
The combustion gases generated by the $\mathrm{LNCB}^{\mathrm{TM}}$ burners in the lower furnace are likely to be more corrosive to the waterwalls than those by standard cell burners. The increased corrosivity is primarily attributed to the substoichiometric combustion of sulfur-containing coal, which promotes the formation of $\mathrm{H}_{2} \mathrm{~S}$-bearing reducing gases. An enlarged flame size from the low-NO $\mathrm{N}_{\mathrm{x}}$ operation would also increase the furnace wall areas exposed to the corrosive gases.

Due to the increased corrosion potential, it was essential to determine the gas compositions in the lower furnace of JMSS4 prior to the retrofit, which could be used as baseline to precisely quantify the effects of $\mathrm{LNCB}^{\mathrm{TM}}$ burners on the corrosion of furnace walls. The measured gas composition, flue gas velocity, and gas temperature would also provide a direct linkage between the actual boiler performance and numerical modeling prediction.

B\&W performed in-furnace gas probing in JMSS4 during the baseline testing to determine the gas temperatures, gaseous species, and gas velocities using a 28 -foot long water-cooled probe. The probe consisted of a thermocouple in the tip to measure the flue gas temperature, static and velocity taps to measure flue gas velocity and direction, and a flue gas sampling line to extract furnace gas for chemical analysis. This effort was first of such kind to probe the gases in a full-size utility boiler. The data obtained included:

- The $\mathrm{H}_{2} \mathrm{~S}, \mathrm{CO}$, and $\mathrm{O}_{2}$ concentrations of the flue gas in the burner zone of JMSS4 - information essential for the corrosive evaluation.

- The distributions of gas species, velocities, and temperatures in the boiler - information useful for the numerical modeling.

This section summarizes the results of the baseline testing.

\subsection{Environmental Effects of Standard Cell Burners}

The environmental effects of the standard cell burners prior to the burner retrofit at JMSS4 are discussed in this section. The burner design and arrangement of JMSS4 were typical of B\&W boilers equipped with standard cells. Therefore, the following discussion should be applicable to all utility boilers in this class.

2.2.1 NO $\mathrm{N}_{\mathrm{x}}$ Emissions. $\mathrm{NO}_{\mathrm{x}}$ emissions of $\mathrm{JMSS} 4$ were measured by both $\mathrm{B} \& \mathrm{~W}$ and Acurex. However, the measuring methods and locations were different. $\mathrm{B} \& W$ measurements involved monitoring $\mathrm{NO}_{\mathrm{x}}$ concentrations of composite flue gas samples from the test grid at the airheater outlet with a $\mathrm{NO}_{\mathrm{x}}$ analyzer. Acurex collected data from a test grid at the economizer outlet by sampling each grid point.

At full load, the average $\mathrm{NO}_{\mathrm{x}}$ emission rates determined by Acurex were $1.217 \mathrm{lbm} / 10^{6} \mathrm{Btu}$ with all mills in service and $1.186 \mathrm{lbm} / 10^{6} \mathrm{Btu}$ with one mill out of service. The $\mathrm{NO}_{\mathrm{x}}$ emissions determined by $\mathrm{B} \& \mathrm{~W}$ were $1.150 \mathrm{lbm} / 10^{6} \mathrm{Btu}$ with all mills in service and $1.053 \mathrm{lbm} / 10^{6} \mathrm{Btu}$ with one mill out of service.

At the intermediate load, average $\mathrm{NO}_{\mathrm{x}}$ emission rates were $0.964 \mathrm{lbm} / 10^{6}$ Btu by Acurex and $0.921 \mathrm{lbm} /$ $10^{6} \mathrm{Btu}$ by B\&W. Low load emissions rates were $0.922 \mathrm{lbm} / 10^{6} \mathrm{Btu}$ by Acurex and $0.703 \mathrm{lbm} / 10^{6} \mathrm{Btu}$ by $\mathrm{B} \& \mathrm{~W}$. The reported $\mathrm{NO}_{\mathrm{x}}$ emissions were very consistent based on the data calculated by these companies. 
2.2.2 CO Emissions. CO emissions were determined at the economizer outlet by both B\&W and Acurex. B\&W measurements were collected from the composite flue gas samples via the sampling grid located between the economizer and airheater, while Acurex data were collected from point-by-point samples at this location.

CO concentrations determined by $B \& W$ averaged of $26 \mathrm{ppm}$ for full-load operation with all mills in service, and $30 \mathrm{ppm}$ for full load with one mill out of service. Corresponding $\mathrm{CO}$ averages by Acurex were $120 \mathrm{ppm}$ and $7 \mathrm{ppm}$, respectively. For the intermediate load, B\&W reported an average of $17 \mathrm{ppm}$ $\mathrm{CO}$, while Acurex measured $110 \mathrm{ppm} \mathrm{CO}$. The averaged $\mathrm{B} \& W \mathrm{CO}$ measurement for low load was 20 $\mathrm{ppm}$, and the averaged Acurex value was $97 \mathrm{ppm}$. Accurex data were consistently higher than those measured by $B \& W$.

The large discrepancies in the $\mathrm{CO}$ emission data were possibly caused by the sampling techniques used by $B \& W$ and Acurex. Several efforts were made during baseline testing to identify the source of discrepancies. However, the efforts were not successful. For example, both Acurex and B\&W re-calibrated their instruments with each other's calibration gases, and the correct $\mathrm{CO}$ concentrations of these gases were measured. However, when the instruments were reconnected to the respective sampling trains, the discrepancies appeared again.

2.2.3 $\mathrm{H}_{2} \mathrm{~S}$ Measurements. The in-furnace gas probing was conducted by $\mathrm{B} \& \mathrm{~W}$ at locations below the lowest burner elevation. The $\mathrm{H}_{2} \mathrm{~S}$ concentrations were determined by a gas chromatograph (GC), which had a resolution of approximately $20 \mathrm{ppm}$. Results showed that out of 14 sample points only one sample at the left front corner of the boiler contained measurable $\mathrm{H}_{2} \mathrm{~S}$. However, measurable $\mathrm{H}_{2} \mathrm{~S}$ was found at nine of the 10 sampling points at the right front corner, with the $\mathrm{H}_{2} \mathrm{~S}$ concentrations ranging up to $90 \mathrm{ppm}$ and averaged at $21 \mathrm{ppm}$.

During the baseline gas probing, several problems associated with the probe design were identified. For example, flue gas condensation occurred inside the heated Teflon ${ }^{\circledR}$ line due to inappropriate temperature control with heat tapes, and warping of the 28 -foot probe developed due to insufficient cooling. In addition, the ceramic filter placed at the probe tip to remove particulate matter did not last for more than five minutes. As a result, contamination in the sampling line had occurred. Consequently, the measured $\mathrm{H}_{2} \mathrm{~S}$ values during the baseline testing were believed to contain considerable errors. Based on these problems, the sampling probe design was modified after the baseline testing.

2.2.4 Particulate Emissions. A typical electrostatic precipitator (ESP) contains a hopper-bottomed box with rows of vertical plates forming gas passages. Centrally located in each passage are emitting electrodes energized with a high negative-polarity voltage from a direct current (DC) transformer rectifier. The applied voltage is high enough to ionize the gaseous molecules close to the electrodes and form a visible corona. The ionized gases flow from the emitting electrodes across the gas passages to the grounded collecting plates, constituting the "corona current." Consequently, the charged ions collide with and attach themselves to fly ash particles suspended in the flue gas. The electric field forces the charged particulates out of the gas stream toward the grounded plates where they are collected. The plates are periodically cleaned by rapping to release the ash cake layer into the ash hoppers.

The ESP collection efficiency increases rapidly as the voltage applied to the emitting electrode is increased. But the voltage cannot be increased above the level at which an electric short circuit (or arcing) occurs between the electrode and ground. The maximum voltage applied to the emitting electrode without arcing is primarily limited by the properties of the fly ash. 
During operation, a layer of fly ash is deposited on the collecting plate surfaces. This layer creates a voltage drop equal to the product of the current density and the resistivity of the flyash. The flyash resistivity, which varies with the temperature and chemistry of the gas stream and the ash chemical compositions, plays a key role in the dust-layer breakdown and ESP performance. Flyash resistivities below about $2 \times 10^{10} \mathrm{ohm}-\mathrm{cm}$ do not generally limit the corona-current density and ESP voltage to the point of affecting the ESP performance. Above this value, however, susceptibility to sparking and arcing necessitates operation at lower voltage and leads to a lower collection efficiency. Severe back corona will occur when the resistivity is higher than about $1 \times 10^{12} \mathrm{ohm}-\mathrm{cm}$. Back corona happens when positive ions are generated in the flyash layer, which then migrate toward the emitting electrodes to neutralize the negatively charged particles.

Acurex obtained the flyash resistivity data at both the economizer and airheater outlets. For an improved ESP performance in JMSS4, sulfur trioxide $\left(\mathrm{SO}_{3}\right)$ was injected into the flue gas stream at a location between the economizer and airheater to reduce the flyash resistivity to enhance precipitation performance. Flyash samples were collected at the economizer outlet, upstream of the $\mathrm{SO}_{3}$ injection, and insitu resistivity samples were collected at the airheater outlet, downstream of the $\mathrm{SO}_{3}$ injection. The higher flue gas temperatures at the economizer outlet precluded the use of in situ sampling equipment. Therefore, laboratory analysis of the flyash from this sampling point was necessary.

Results of the laboratory analysis indicated that the ash resistivity before the $\mathrm{SO}_{3}$ injection had an average value of $1.2 \times 10^{13} \mathrm{ohm}-\mathrm{cm}$ at $280^{\circ} \mathrm{F}$. The in situ ash resistivity after the $\mathrm{SO}_{3}$ injection was $2.7 \times 10^{11} \mathrm{ohm}$ $\mathrm{cm}$ at $276^{\circ} \mathrm{F}$. A change of two orders of magnitude in the flyash resistivity apparently resulted from the $\mathrm{SO}_{3}$ injection. The lower the flyash resistivity, the higher the ESP efficiency from the standpoint of power consumption and particle collection.

Acurex obtained the dust loading data from several tests to determine the baseline ESP collection efficiencies for several operating conditions. The methods employed were in accordance with EPA Methods 5 and 17. For the condition of full load with all mills in service and normal excess air, the ESP collection efficiency averaged at $99.50 \%$. The averaged collection efficiency for all of the dust loading tests at different conditions was $99.48 \%$.

2.2.5 Boiler Flyash. Flyash samples were obtained using EPA Method 17 for dust loading (Tests 1, 3, 5, and 8). Acurex collected and analyzed 10 samples for the particle size distribution in accordance with ASME PTC 28 - 1965. A sieve analysis was performed to determine the size distribution above $150 \mu \mathrm{m}$, and a No. 6000 Bahco Particle Classifier was used for those below $150 \mu \mathrm{m}$.

Results showed that particle size distribution was not significantly affected by changing the unit from full load to intermediate or by taking mills out of service. The median size of the flyash particles ranged from $15 \mu \mathrm{m}$ at intermediate load to $53 \mu \mathrm{m}$ at full load. Ten to thirty percent of the particulate matter had a mean aerodynamic diameter of $10 \mu \mathrm{m}$ or less. Nearly all particles had a diameter of less than $75 \mu \mathrm{m}$, which was the design coal fineness of the pulverizers.

\subsection{Boiler Performance}

Temporary gas sampling grids were installed in the gas outlets of the economizer and secondary airheaters to determine the operating excess air levels and secondary airheater leakage rates. Diagrams of these grids are shown in Figures 2-1 and 2-2. The number of sampling points in each of the gas grids is as follows: 
Economizer Gas Outlet

Economizer Gas Outlet

Secondary Airheater Gas Outlet

Secondary Airheater Gas Outlet

$\begin{array}{llll}\text { - } & \text { East Side } & \text { - } & 40(10 \text { wide }-4 \text { high }) \\ \text { - } & \text { West Side } & \text { - } & 40(10 \text { wide }-4 \text { high }) \\ \text { - } & \text { East Side } & - & 36(12 \text { wide }-3 \text { high }) \\ \text { - } & \text { West Side } & - & 36(12 \text { wide }-3 \text { high })\end{array}$

The temporary grids were connected to continuous gas analyzers to determine the volume concentrations of $\mathrm{O}_{2}, \mathrm{CO}$, and $\mathrm{CO}_{2}$. Thermocouples were also incorporated in the grids to measure the averaged gas temperature at these locations. As mentioned previously, the $\mathrm{NO}_{\mathrm{x}}$ emissions were measured by $\mathrm{B} \& \mathrm{~W}$ at the secondary airheater outlet from the grids described above.

$5 / 16$ in. tubing connections to sample lines

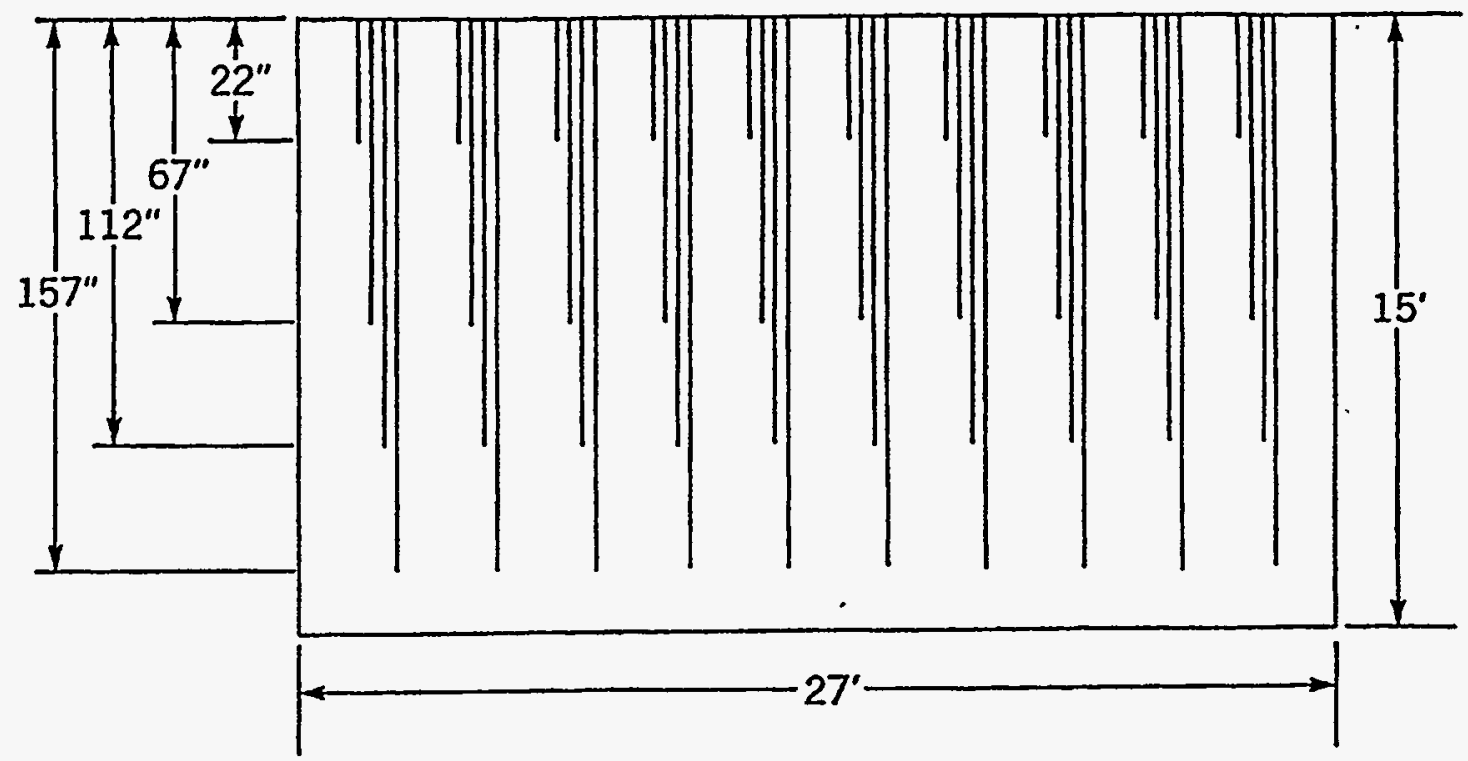

Figure 2-1 Economizer gas sampling grid

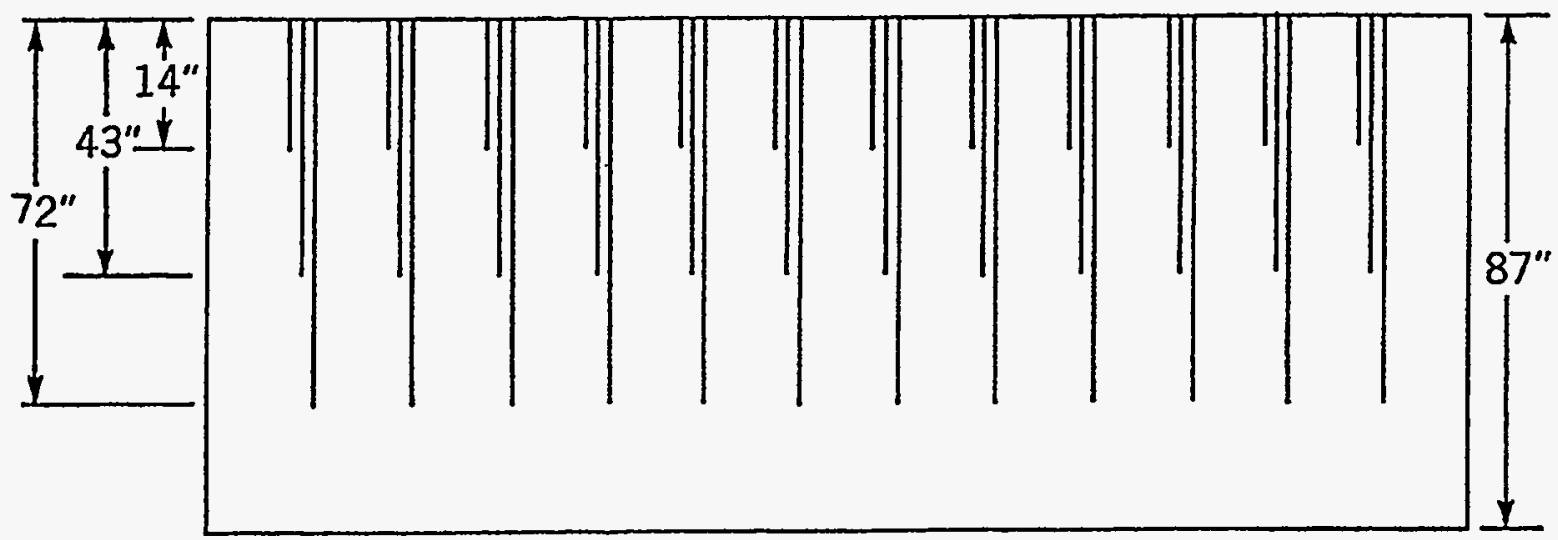

Figure 2-2 Airheater gas sampling grid 
The data recorded by plant instrumentation were also used to determine the boiler performance. The flow instrumentation was used for the feedwater, $\mathrm{RH}$ attemperator spray water, and pulverized coal. Pressures were measured at the inlets of economizer, PSH, RH, as well as the SSH and RH outlets. Temperatures were recorded at various locations of JMSS4, including:

1) Feedwater inlet

2) Economizer water outlet

3) PSH inlet

4) PSH outlet

5) SSH inlet

6) $\mathrm{SSH}$ outlet

7) Turbine throttle

8) Cold RH

9) RH attemperator inlet

10) RH inlet

11) RH outlet

12) Hot RH at the turbine

Temperatures of all four fluid streams around the first and second point feedwater heaters were also measured. Pressures and temperatures critical for the heat transfer performance of JMSS4 were further monitored by $\mathrm{B} \& \mathrm{~W}$ with temporary test instrumentation.

Coal samples were collected by B\&W and sent to an outside laboratory for analysis. Samples were collected at the coal inlet to each feeder during the baseline testing. Additionally, DP\&L collected coal samples from each barge of coal that was received for the tests. Coal samples were analyzed for proximate analysis in accordance with the ASTM Method D3172, "Method for Proximate Analysis of Coal and Coke" and ultimate analysis in accordance with the ASTM Method D3176, "Standard Practice for Ultimate Analysis of Coal and Coke." Baseline and post-retrofit coal analyses are shown in Table 3-1 on page 21.

Ash samples were collected by DP\&L from the bottom ash hopper, economizer outlet hopper, and the ESP first field hoppers for most of the tests. The ash samples generated from four of the coal samples were analyzed by B\&W's Alliance Research Center in accordance with the ASTM Method D2795, "Standard Test Methods for Analysis of Coal and Coke Ash," ASTM Method D1757, "Standard Test Methods for Sulfur in Ash from Coal and Coke," and ASTM Method D1857, "Standard Test Methods for Fusibility of Coal and Coke Ash."

Ash samples were also collected by $\mathrm{B} \& \mathrm{~W}$ and sent to an outside laboratory for analyses for carbon and $\mathrm{CO}_{2}$ in accordance with ASTM Method D3178, "Test Methods for Carbon and Hydrogen in the Analysis Sample of Coal and Coke" and ASTM Method D1756, "Test Method for $\mathrm{CO}_{2}$ in Coal." Unburned carbon in the ash was then determined by subtracting the carbon in the $\mathrm{CO}_{2}$ from the total reported carbon; B\&W's preferred method.

Because the ash samples were not obtained from all locations during all tests, an average unburned carbon for each ash stream was determined and then a weighted average for all streams was calculated. This averaged carbon content in ash was then used with each fuel analysis to determine the carbon burned for a particular coal sample. 
After completion of baseline testing, collected data were averaged into sets corresponding to individual test periods. These raw and averaged data were then used to calculate the boiler precision indices. Using the precision indices, outliers of the raw data were identified and removed from the analyses. Based on these revised data, B\&W calculated the overall operating performance of JMSS4 in accordance with the following ASME guidelines:

- Power Test Code PTC 4.1-1967, Steam Generators

- Power Test Code PTC 4.2-1969, Coal Pulverizers

- Power Test Code PTC 4.3-1968, Air Heaters

- Instruments and Apparatus, ANSI/ASME PTC 19.1-1985, Part 1 Measurement Uncertainty.

- Instruments and Apparatus, ANSI/ASME PTC 19.10-1985, Part 10 Flue \& Exhaust Gas Analysis

2.3.1 Superheater/Reheater Steam Temperature Control. Reheat spray flows were measured for all tests. Results indicated that reheat attemperation rates had an average of $34.0 \mathrm{klbs} / \mathrm{hr}$ for full load operation with all mills in service, and $39.9 \mathrm{klbs} / \mathrm{hr}$ for full load operation with one mill out of service. During intermediate and low load tests, there were no measurable attemperation flows.

2.3.2 Furnace Exit Gas Temperature (FEGT). FEGT is defined as the temperature of the flue gas at the vertical plane entering the secondary superheater platens. FEGTs were calculated for all of the averaged test data and were reported as high velocity thermocouple (HVT) values. Additionally, actual HVT probing of FEGTs was conducted by B\&W. The HVT probe only determined temperatures for discrete points in the traverse plane, while calculated FEGTs determined the average bulk temperature for the entire furnace exit plane. This is determined with a series of heat balances (heat lost by flue gas equals heat gained by water or steam) starting at the economizer outlet then working toward the secondary superheater. B\&W considered the calculated FEGTs more reliable than the HVT traverse data. As a result, calculated FEGTs were used in all boiler evaluations.

The averaged FEGT calculated at full load was $2528^{\circ} \mathrm{F}$ with all mills in service and $2508^{\circ} \mathrm{F}$ with one mill out of service. The FEGT was at $2354^{\circ} \mathrm{F}$ for the intermediate loads and $2136^{\circ} \mathrm{F}$ for the low load conditions. In comparison, averaged FEGTs from HVT traverses were $2549^{\circ} \mathrm{F}$ for the full load tests and $2376^{\circ} \mathrm{F}$ for the intermediate load tests.

2.3.3 Surface Cleanliness. The cleanliness factor $\left(\mathrm{K}_{\mathrm{f}}\right)$ is a measure of the heat transfer performance of each unit component. Fouling and slagging would cause a decrease in $\mathrm{K}_{\mathrm{f}}$ due to the increase in resistance to heat transfer through the deposit layer. The resulting $\mathrm{K}_{\mathrm{f}} \mathrm{s}$ vary from component to component depending on the degree of fouling and slagging.

The cleanliness of JMSS4 was very close to what B\&W expected. The averaged $\mathrm{K}_{\mathrm{f}}$ at the secondary superheater outlet bank were 0.92 for all tests and 0.91 for the tests at full load; with a $\mathrm{K}_{\mathrm{f}}=1.0$ considered normal cleanliness. The reheat superheater $\mathrm{K}_{\mathrm{f}} \mathrm{s}$ had an average of 0.98 for all of the tests and 0.97 for the tests at full load. $\mathrm{K}_{\mathrm{f}} \mathrm{s}$ for the secondary superheater inlet bank (18-inch side spacing) averaged 1.11 for all tests and 1.10 for full load tests. The primary superheater $\mathrm{K}_{\mathrm{f}} \mathrm{s}$ averaged 1.00 for all tests and 1.01 at full load. The economizer $\mathrm{K}_{\mathrm{f}} \mathrm{s}$ averaged 1.11 for all of the tests and 1.09 for full load.

Measured $\mathrm{K}_{\mathrm{f}} \mathrm{s}$ indicated that the heat transfer for the SSH inlet bank was more effective than expected, while the SSH outlet bank was less effective than expected. However, the overall performance of the SSH met expectations. The inconsistency can probably be attributed to the measured steam temperature 
SSH met expectations. The inconsistency can probably be attributed to the measured steam temperature leaving the inlet bank of the SSH, which could be in error due to the lack of a sufficient number of working thermocouples.

Results showed that the primary superheater and reheater performed as expected, and the economizer performed better than anticipated.

2.3.4 Unburned Carbon Loss. As indicated previously, the coal ash samples were periodically collected from the boiler bottom ash hopper, the boiler outlet hopper, and the ESP first field hopper. Additional ash samples were collected by Acurex utilizing an EPA Method 17 test probe.

The unburned carbon levels determined for the flue dust by B\&W and Acurex differed by an amount that was considered worth further investigation. It is noted that different methods of sample collection and analysis were used. B\&W collected samples from the hoppers underneath the first field of the ESP and analyzed them in accordance with ASTM Methods D3178 and D1756. On the other hand, Acurex used an isokinetic sampling probe for collection and analyzed the sample for loss on ignition (LOI), as described in the ASME Power Test Code ANSI/ASME PTC 28-1965, "Determination of Properties of Fine Particulate Matter." The unit efficiencies calculated using B\&W's data were lower than that using the Acurex's LOI data. (For Acurex data, see page A-3)

Upon further review, neither procedure was totally correct. In comparison, ash sampling with an isokinetic probe would be more suitable for units with an ESP. However, the ASTM analysis methods would be more accurate for determining of unburned carbon because the LOI method does not account for moisture, carbonates, or the presence of volatile noncombustibles.

An effort was made to check the consistency of unburned carbon analyses. B\&W submitted the ESP hopper samples to Acurex for analysis using both the LOI and ASTM methods, while the same samples were also sent to an outside laboratory for LOI tests. Test results did not show good agreement. However, overall unit efficiency was not significantly affected (less than $0.2 \%$ ) compared to the calculated value given below.

2.3.5 Efficiency Calculations. Unit efficiency was determined based on average fuel analyses for the corresponding test period. The unit was performing quite well with full load efficiencies, averaging 89.59\% for full load operation with all mills in service and normal excess air. The efficiency for full load and one mill out of service averaged $89.83 \%$. When corrected to the expected fuel analysis and air temperatures, the efficiency for full load and all mills in service was $89.43 \%$, and that for full load and one mill out of service was $89.64 \%$.

The fact that unit efficiency was actually better under the condition of one mill out of service can be attributed to the lower airheater outlet temperatures. With one mill out of service, there was less air bypassing the airheater for use as tempering air to the mills, thus causing more heat to be recovered by the secondary air in the airheaters.

Efficiency averaged $89.73 \%$ for intermediate load and $90.18 \%$ for the low load condition. The trend toward higher efficiencies at reduced loads was normal, due primarily to a decrease in the airheater end temperature difference. 
2.3.6 Coal Fineness. All six pulverizers at JMSS4 are rated for a $108,000 \mathrm{lbs} / \mathrm{hr}$ coal flow with an HGI of 50 . This HGI rating is designed to allow $70 \%$ of the pulverized coal leaving each mill to pass a USS 200 Mesh screen. B\&W collected and seived the pulverized coal samples at the outlets of the pulverizers. Fineness results showed that an average of $95.2 \%$ passed a USS 50 Mesh screen and $54.7 \%$ passed a USS 200 Mesh screen. The coal was not tested for hardness during baseline tests.

The relatively low amount of coal passing through 200 Mesh was caused by the higher than designed primary airflow through the pulverizers. The pulverizer throats had deteriorated and needed replacement. This condition forced DP\&L to use additional primary air to control pulverizer rejects. As more primary air was used, primary air temperature decreased, forcing an increase in tempering air. As more tempering air bypassed the secondary airheater, less heat was recovered from the flue gas. Consequently, a higher gas temperature was leaving the airheater, and a lower boiler efficiency was observed. 


\section{Section 3 \\ NUMERICAL FLOW AND COMBUSTION MODELING}

\subsection{Introduction}

The objective of the numerical modeling activity is to validate B\&W's numerical flow and combustion models by comparing the model predictions to baseline and post-retrofit test data. The validated models can subsequently be used to characterize performance of utility boilers equipped with $\mathrm{LNCB}^{\mathrm{TM}}$ burners.

B\&W's proprietary numerical flow model - FORCE - and combustion and heat transfer model FURMO - were used to simulate the operation of JMSS4. The FORCE flow model solves the steadystate, Reynolds averaged form of the Navier-Stokes equations for conservation of mass and momentum in three dimensions. FORCE has been designed to facilitate the definition of complex geometries of fullscale combustion equipment. Features, including arches and tube banks, can be included in FORCE models. The FURMO model solves equations for chemical species and energy for coal combustion in a furnace. FURMO models heterogeneous coal reactions including devolatilization and char oxidation, homogeneous gas-phase reactions, and volatile combustion. These features allow FURMO to calculate volatile release rates, species concentrations, flame shape and temperature, and char burnout. FURMO calculates radiative and convective heat transfer to the furnace walls and the convection pass surfaces. Radiation heat transfer is modeled using state-of-the-art methods developed by $B \& W$ for calculating the absorption and scattering characteristics of gas mixtures containing coal, char, soot, and flyash. The results include three-dimensional distributions of gas temperature and gas species concentrations in the model geometry.

\subsection{Methodology}

To utilize the FORCE and FURMO models, the furnace volume is divided into sub-volumes called control volumes. The furnace geometry and computational grid used in the numerical combustion and heat transfer modeling is shown in Figure 3-1. The grid lines of the FURMO computational grid coincide with grid lines used in the FORCE computational grid. However, due to the greater computational requirements of FURMO, fewer control volumes are used with FURMO than with FORCE. Although considered relatively coarse when compared to current models, the grid was refined as much as possible to allow timely solutions on the work station computers available at the time the project began. To maintain consistency, the same FORCE and FURMO grids were used for all of the modeling on this project, including the analyses to mitigate the high $\mathrm{CO}$ concentrations in the hopper.

The furnace is modeled from the burner throats through the horizontal section of the convection pass. The computational grid is finer in the burner zone and in the upper furnace where high gradients of density and species concentrations exist. Convection pass heat transfer surfaces are modeled as porous media with convective surface heat transfer and modified radiation absorption and scattering properties. The furnace enclosure is modeled with convective surface heat transfer and constant emissivity. The net 
heat absorbed through the furnace walls and convection pass heat transfer surfaces can be adjusted by modifying the overall thermal boundary condition to allow for uncertainties in the thickness and thermal conductivity of furnace ash, slag deposits or tube bank fouling.

\section{Plan View}

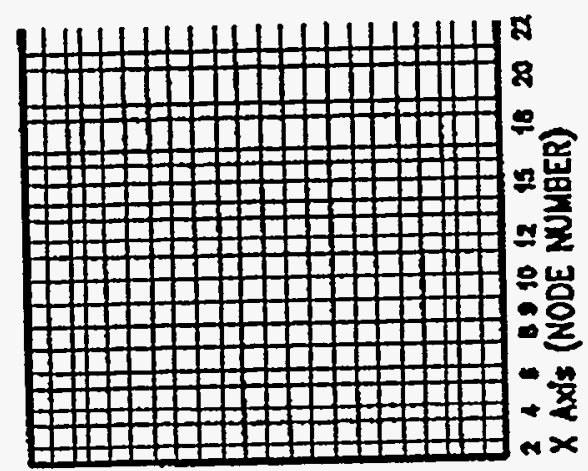

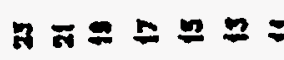

Front Elevation

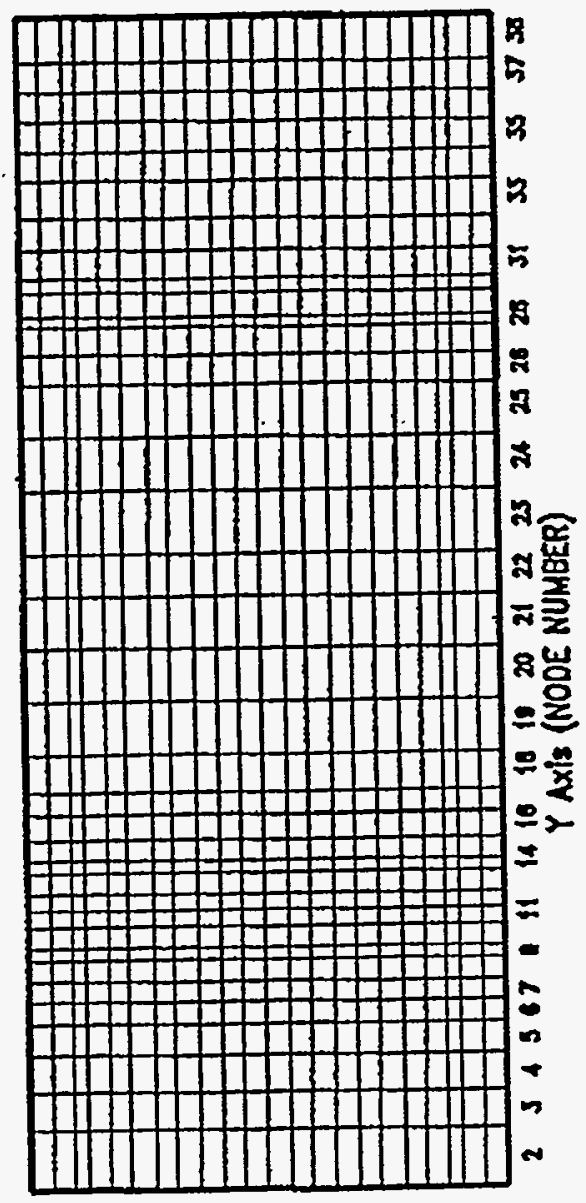

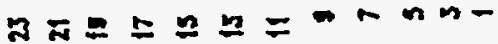

2 AxIS (NODE NUMBER)

Figure 3-1 FURMO computational grid

Side View

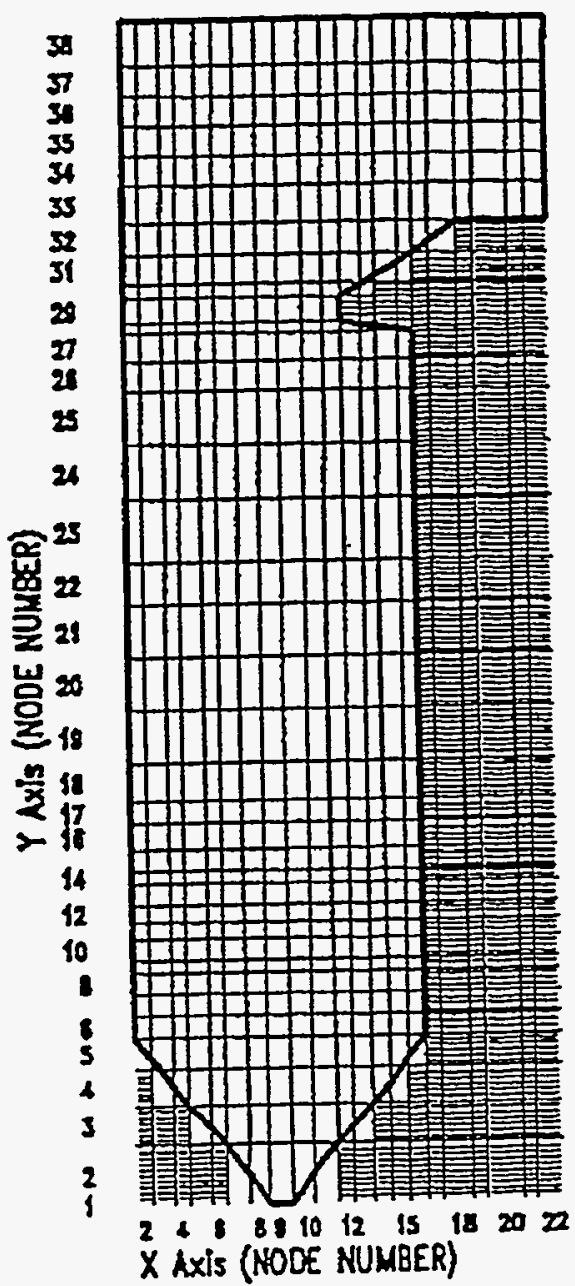


The FURMO model calculates the combustion and heat transfer of the furnace using the following information:

- The flow field generated by FORCE

- The coal composition, fineness, temperature, and higher heating value (HHV)

- Air composition and temperature

- Thermal wall boundary conditions

Furnace heat transfer performance data from the full load tests were used to adjust the thermal boundary conditions for the furnace wall and convection pass heat transfer surfaces. This compensated for the uncertainty in furnace slagging and fouling conditions. The heat transfer boundary conditions were then assumed to remain constant for the intermediate load modeling. The resulting thermal conductance of the furnace was slightly higher for the post-retrofit model than for the baseline model, indicating less overall slagging and fouling in the furnace.

The numerical modeling simulated the operation of JMSS4 at full and intermediate loads using the actual operating conditions during the in-furnace probing. The operating conditions and fuel analyses used for the modeling are listed in Table 3-1. The condition for the full load baseline modeling is a composite of the average conditions of Baseline Tests $1,1 \mathrm{CA}, 1 \mathrm{CB}$, and 2 . The baseline intermediate load condition is from Test 3. For the post-retrofit modeling, the full load condition is from Test 1 , and the intermediate load condition is from Test 5 .

The FORCE model calculates the flow field in the furnace based on the inlet flow rate and momentum of the burners and air ports. The mass flow, axial momentum, and swirl intensity of the burners and air ports are calculated using the geometry and flow control settings. The baseline arrangement and swirl pattern of the standard cell burners on JMSS4 is shown in Figure 3-2, and the post-retrofit arrangement and swirl of the LNCB ${ }^{\mathrm{TM}}$ burners is shown in Figure 3-3. For the baseline modeling, the air and coal distribution to the standard cell burners was assumed to be uniform. A uniform air distribution is unlikely with the wrap-around windbox and the relatively low pressure drop of the standard cell burners. The models do not require that uniform distributions be used, but not enough reliable information was available that could be used to determine the actual burner-to-burner distribution of the air or coal.

Flow modeling of the windbox could have been performed to predict the air flow distribution, but was beyond the scope of this project.

During the post-retrofit testing, the coal and primary air flow rates were measured for each mill. The coal and primary air flow rates for individual burners were not measured, so any possible burner-toburner variations could not be determined. The secondary air flow distribution was determined from impact-suction pitot tube arrays on each burner. The air-fuel ratio for each burner was calculated using average coal and primary air flow rates calculated from the mill totals and the measured secondary air flow rate. Since more detailed burner-to-burner measurements did not exist and the air-fuel ratios were relatively uniform, a uniform coal and air distribution to each burner was assumed that gave the calculated average air-fuel ratio. 
NUMERICALLY MODELED OPERATING CONDITIONS

\begin{tabular}{|c|c|c|c|c|c|}
\hline 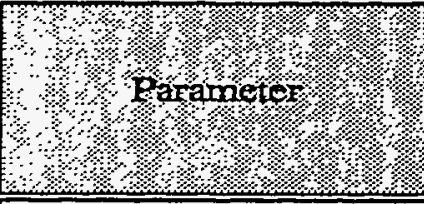 & 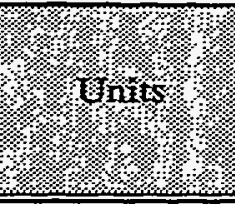 & \%彳, & (10\%) & (8) & 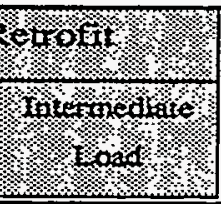 \\
\hline Output & MWe & 605 & 458 & 603 & 461 \\
\hline Temperatures & & & & & \\
\hline Windbox & $\mathbf{F}$ & 619 & 589 & 599 & 562 \\
\hline Pulverizer Outlet & $\mathbf{F}$ & 149 & 149 & 150 & 150 \\
\hline Moisture in Air & $1 \mathrm{bm} / \mathrm{lbm}-\mathrm{d} r \mathrm{y}$ air & 0.0073 & 0.0038 & 0.0130 & 0.0130 \\
\hline Coal Flow Rate & $\mathrm{Klbm} / \mathrm{hr}$ & 453.8 & 351.0 & 450.4 & 362.0 \\
\hline Air Flow Rates & & & & & \\
\hline Burners & $\mathrm{K}, \mathrm{lbm} / \mathrm{hr}$ & 4906.2 & 4121.3 & 2207.6 & 2016.8 \\
\hline Air Ports & $\mathrm{Klbm} / \mathrm{hr}$ & N/A & N/A & 2524.7 & 2150.1 \\
\hline Total & $\mathrm{Klbm} / \mathrm{hr}$ & 4906.2 & 4121.3 & 4732.2 & 4166.9 \\
\hline Stoichiometric Ratios & & & & & \\
\hline Burners & & 1.212 & 1.333 & 0.550 & 0.580 \\
\hline Fumace & & 1.212 & 1.333 & 1.179 & 1.334 \\
\hline Mills Out of Service & 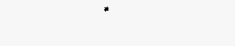 & None & $A$ & None & A \\
\hline Burners Out of Service & & None & 8 & None & $4^{*}$ \\
\hline Ultimate Analysis & & & & & \\
\hline (As Received) & & & & & \\
\hline Carbon & $\%$ & 66.52 & 65.95 & 65.75 & 63.49 \\
\hline Hydrogen & $\%$ & 4.49 & 4.48 & 4.64 & 4.50 \\
\hline Oxygen & $\%$ & 7.51 & 7.91 & 7.78 & 7.14 \\
\hline Nitrogen & $\%$ & 1.23 & 1.16 & 1.41 & 1.37 \\
\hline Sulfur & $\%$ & 1.00 & 1.12 & 0.78 & 0.74 \\
\hline Moisture & $\%$ & 5.55 & 5.39 & 4.76 & 6.10 \\
\hline Ash & $\%$ & $\underline{13.70}$ & 13.99 & 14.88 & $\underline{16.66}$ \\
\hline & & 100.00 & 100.00 & 100.00 & 100.00 \\
\hline $\begin{array}{l}\text { Proximate Analysis } \\
\text { (As Received) }\end{array}$ & & & & & \\
\hline Moisture & $\%$ & 5.55 & 5.39 & 4.76 & 6.10 \\
\hline Fixed Carbon & $\%$ & 47.61 & 47.24 & 38.54 & 35.28 \\
\hline Volatile Matter & $\%$ & 33.14 & 33.38 & 41.82 & 41.96 \\
\hline Ash & \% & $\underline{13.70}$ & 13.99 & $\underline{14.88}$ & $\underline{16.66}$ \\
\hline & & 100.00 & 100.00 & 100.00 & 100.00 \\
\hline Higher Heating Value (HFIV) & Bru/bm & 11,880 & 11,839 & 11,845 & 11,370 \\
\hline Test Identification Numbers & & $1,1 \mathrm{CA}, 1 \mathrm{CB}, 2$ & 3 & 1 & 5 \\
\hline
\end{tabular}

* - The burners' adjacent air ports were also out of service. 

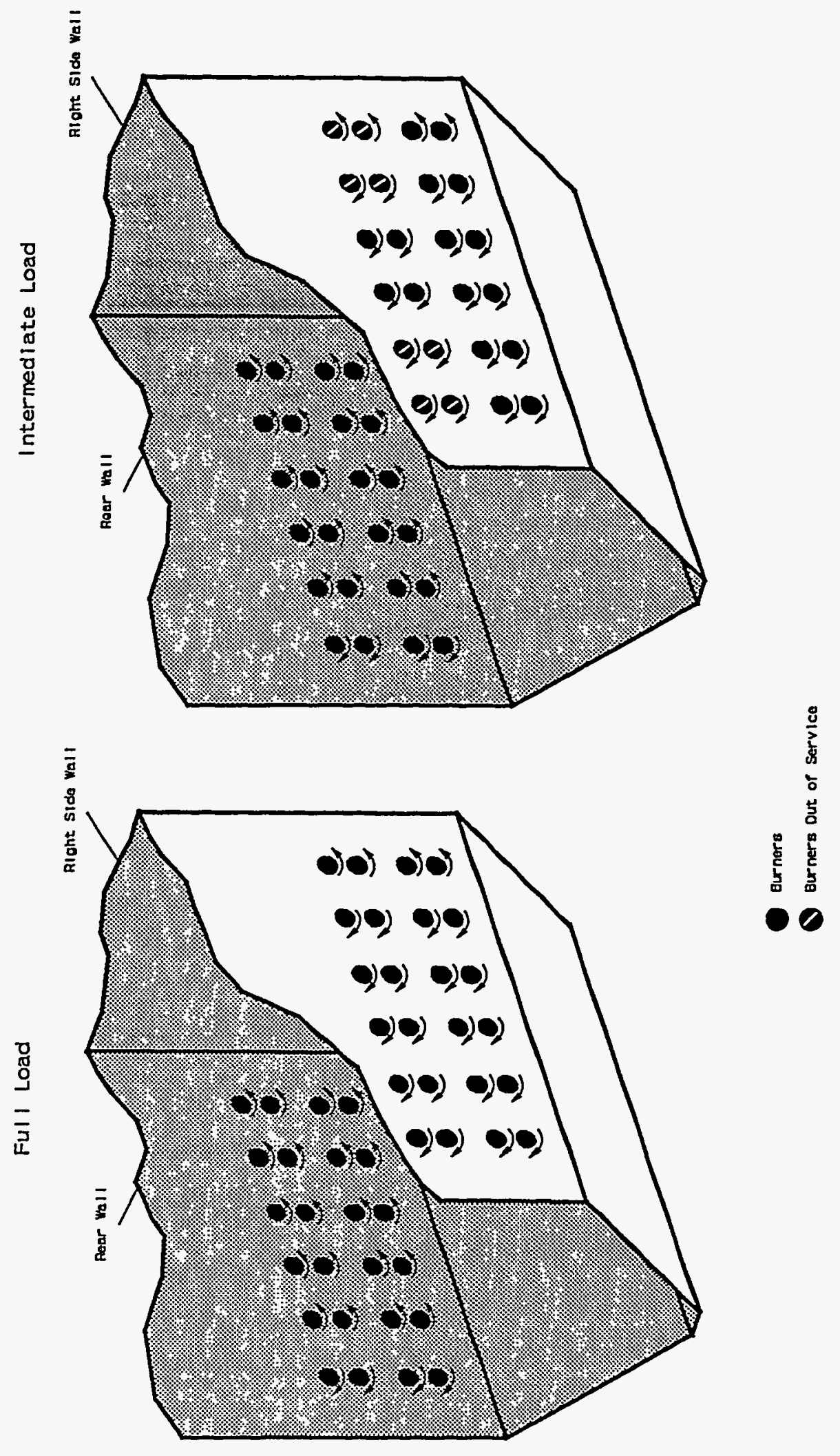

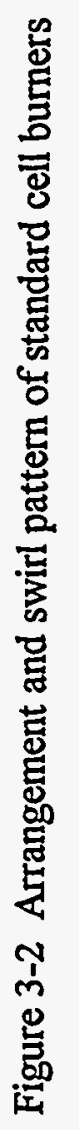




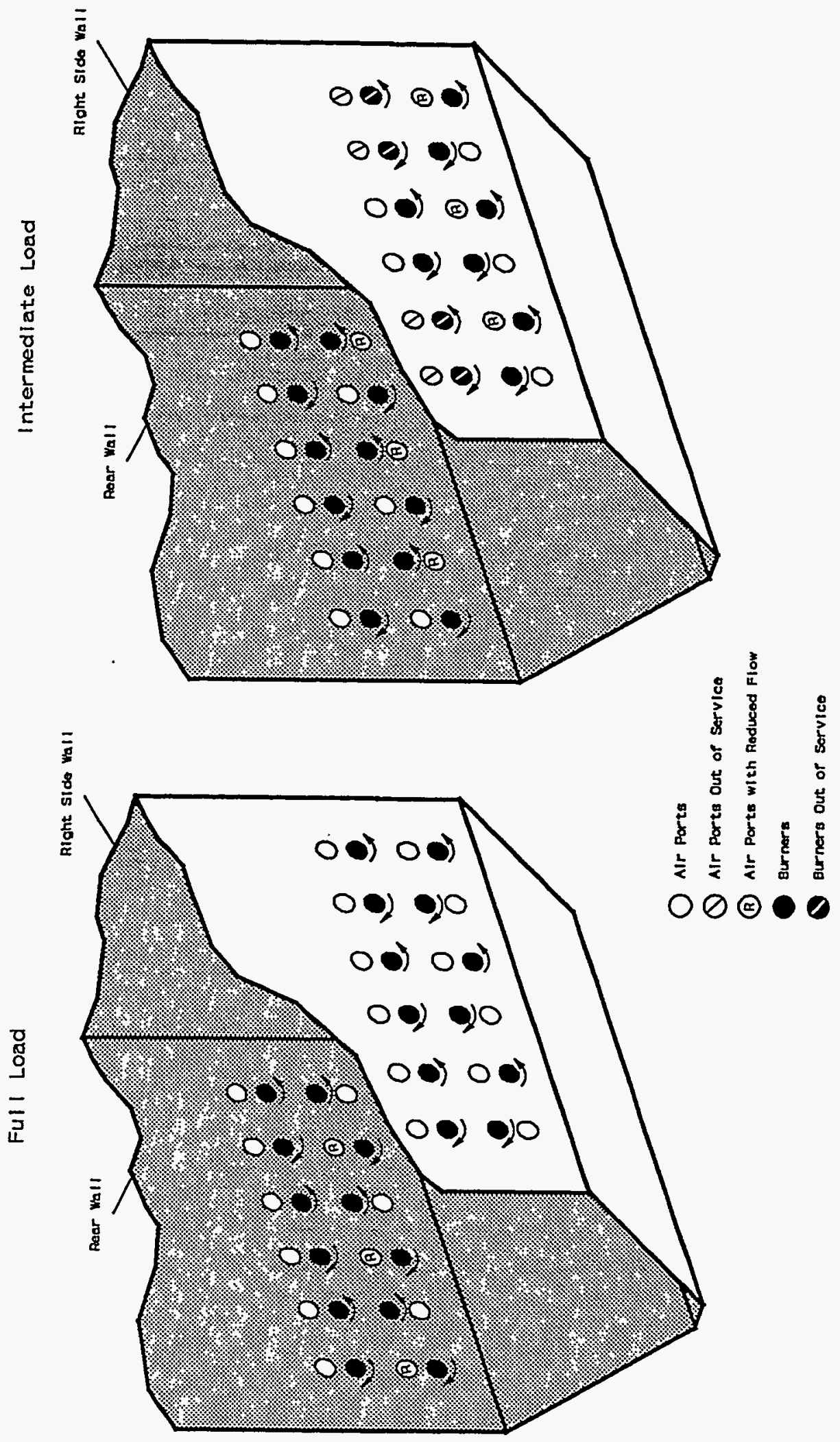

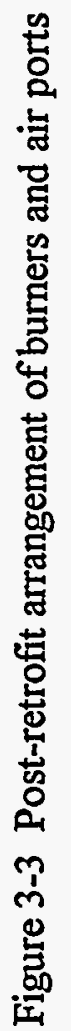


Each air port was also equipped with an impact-suction pitot tube array. At full load, the measured flow rate for 21 of the 24 air ports was within $\pm 5 \%$. A uniform distribution between these 21 air ports was assumed. The flow rates for each of the remaining three air ports was about $50 \%$ lower than the average of the other 21. The air flow through these three ports, which are located on the rear wall in the row of inverted cells (see Figure 3-3), was restricted to further reduce $\mathrm{NO}_{\mathrm{x}}$ emissions and direct more air to other ports for better carbon conversion. A uniform air distribution was assumed.

Locations of the four out-of-service burners and air ports at intermediate load are shown in Figure 3-3. The secondary air flow to the out-of-service burners was the same as the flow to the in-service burners. All of the burners and air ports have a damper position for out-of-service cooling. The out-of-service burners require essentially as much air flow as the in-service burners to provide cooling to the burner components. As with full load, a uniform coal and primary air distribution between in-service burners was assumed. The measured air flow rate for 14 of the 20 in-service ports were within $\pm 5 \%$, so a uniform air distribution between these ports was assumed. The air flow rate to each of the six remaining inservice ports was approximately $30 \%$ less than the average of the other 14 in-service ports. The flow to these ports was restricted for the same reasons noted for full load. A uniform distribution was assumed between these six ports. The locations of the six ports with reduced flow are shown on Figure 3-3. The air flow rate for the ports adjacent to the out-of-service burners was about $40 \%$ less than the flow rates of the 14 in-service ports. A uniform air flow distribution to the out-of-service air ports was assumed.

\subsection{Results}

Initially, flow and combustion modeling were performed before the retrofit to determine the impact of the $\mathrm{LNCB}^{\mathrm{TM}}$ burners on furnace performance. The model indicated lower combustion temperatures implying lower thermal $\mathrm{NO}_{x}$; insignificant increases in unburned carbon; and a more uniform distribution of furnace exit gas flow and temperature. Although the predicted average FEGT increased by $7^{\circ} \mathrm{F}$, the predictions showed less side-to-side variation and had lower peak to minimum values.

The model predictions did indicate that high $\mathrm{CO}$ concentrations existed below the burners. However, the predicted concentrations above the burners and at the furnace exit were similar to the pre-retrofit predictions and measurements. In pilot-scale studies, the few $\mathrm{CO}$ measurements that were made below the burners indicated concentrations that were much lower than the pilot- or full-scale predictions. No fullscale data existed to either confirm or deny the unexpectedly high $\mathrm{CO}$ concentrations below the burners. Subsequent preliminary post-retrofit testing results confirmed the high $\mathrm{CO}$ concentrations below the lowest burner row.

3.3.1 CO Mitigation. The numerical models were used to evaluate strategies for reducing $\mathrm{CO}$ concentrations below the burner level and to assess their impact on furnace performance. To mitigate the $\mathrm{CO}$, a strategy was needed that injected more air into the hopper without required pressure part modifications; increased costs, or reduced unit efficiency. The $\mathrm{CO}$ mitigation strategies included modifying burner and air port flow control settings with the initial installation and inverting selected lower row cells. The modeling results indicated that inverting alternating lower row cells would reduce hopper $\mathrm{CO}$ concentrations to pre-retrofit levels without affecting the furnace heat transfer, reducing the unit efficiency or requiring additional equipment, controls or pressure part modifications. The modeling evaluation and results are discussed in detail in Section 4.

3.3.2 Furnace Exit Gas Temperature (FEGT). The predicted FEGTs for the baseline and postretrofit cases are illustrated in Figure 3-4. The predicted FEGT is essentially the same with the standard 
cell or the $\mathrm{LNCB}^{\mathrm{TM}}$ burners at full and intermediate loads, even though the furnace wall absorptions were slightly different. The modeling results indicate that the retrofit caused only minor changes in the furnace heat transfer performance.

3.3.3 Comparisons With Data. During baseline testing, extensive in-furnace probing was conducted at the furnace exit and at a horizontal plane 40 feet above the burners. The probe traverse planes are illustrated in Figure 3-5. Measurements of gas velocity, gas temperature and chemical species were made at full ( $605 \mathrm{MWe}$ ) and intermediate ( $458 \mathrm{MWe}$ ) loads. The gas velocity, gas temperature, and oxygen concentration predictions were compared with the extensive baseline test data. The extensive in-furnace probing was repeated during the post-retrofit optimized testing. The flow, combustion, and heat transfer modeling simulated the post-retrofit operation at full load (603 MWe) and intermediate load (461 MWe). The gas velocity, gas temperature, oxygen $\left(\mathrm{O}_{2}\right)$, and $\mathrm{CO}$ concentration predictions were compared with the post-retrofit test data. The results of the comparison are contained in the optimized testing interim report. The locations where measurements were made, the methods used to obtain the data, and the results of the comparison are summarized below.

The data were obtained by inserting a water-cooled HVT/Fechheimer probe into the furnace through observation doors and recording measurements at two-foot intervals as the probe was retracted from the furnace. Figure 3-6 shows the sampling locations at the furnace exit plane. The sampling locations shown assume that the probe did not sag inside the furnace. The locations in this report are referenced to the floor level on JMSS4. The probes were inserted through both side walls and extended 20 feet into the furnace. The furnace width is 63 feet, so no data were obtained for the 23 feet in the middle of the furnace exit plane. The length of the probe is 27 feet measured from the cooling water connections to the tip. Seven feet of the probe was needed to clear the buckstay, lagging, and insulation, and to allow for handling. Use of a longer probe would not have been feasible due to handling and cooling constraints.

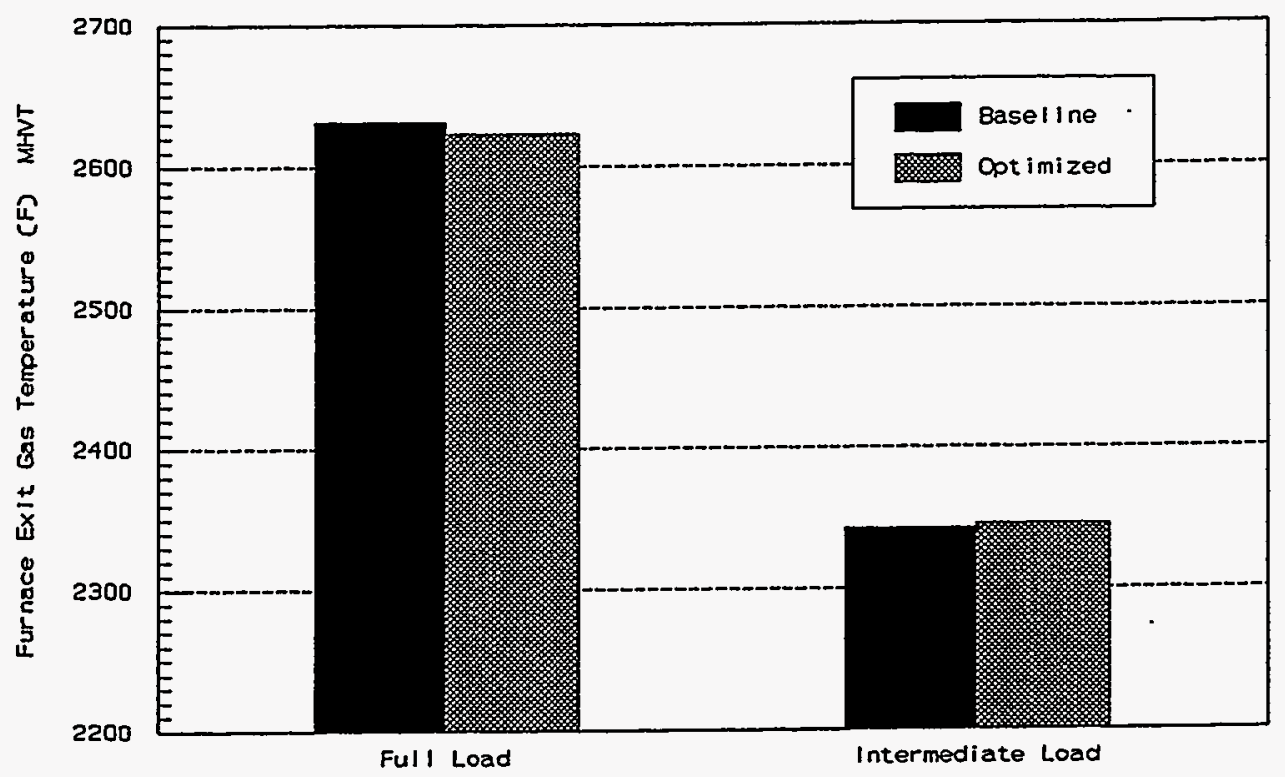

Figure 3-4 Predicted furnace exit gas temperatures 

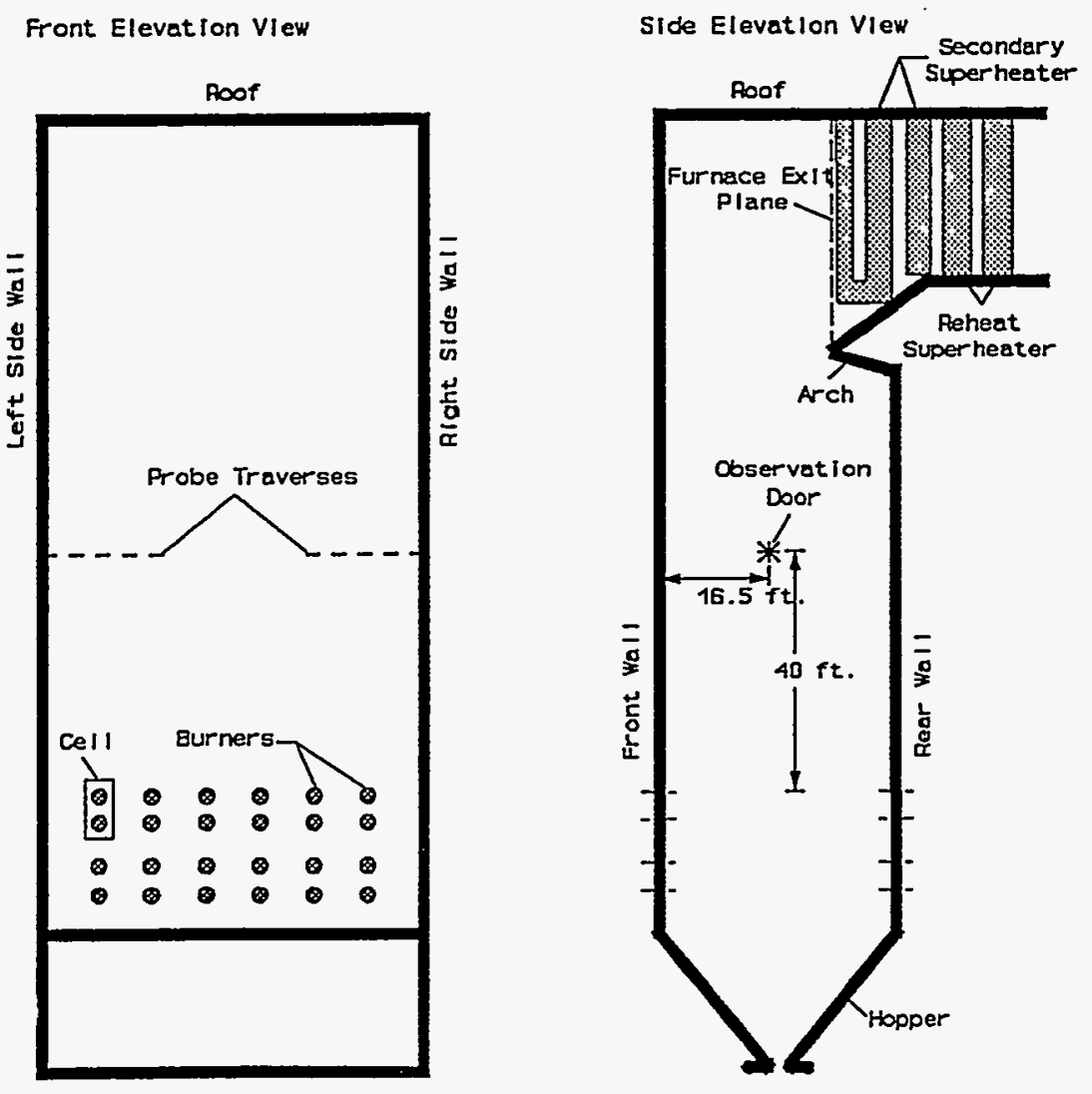

Figure 3-5 Traverse locations on JMSS4

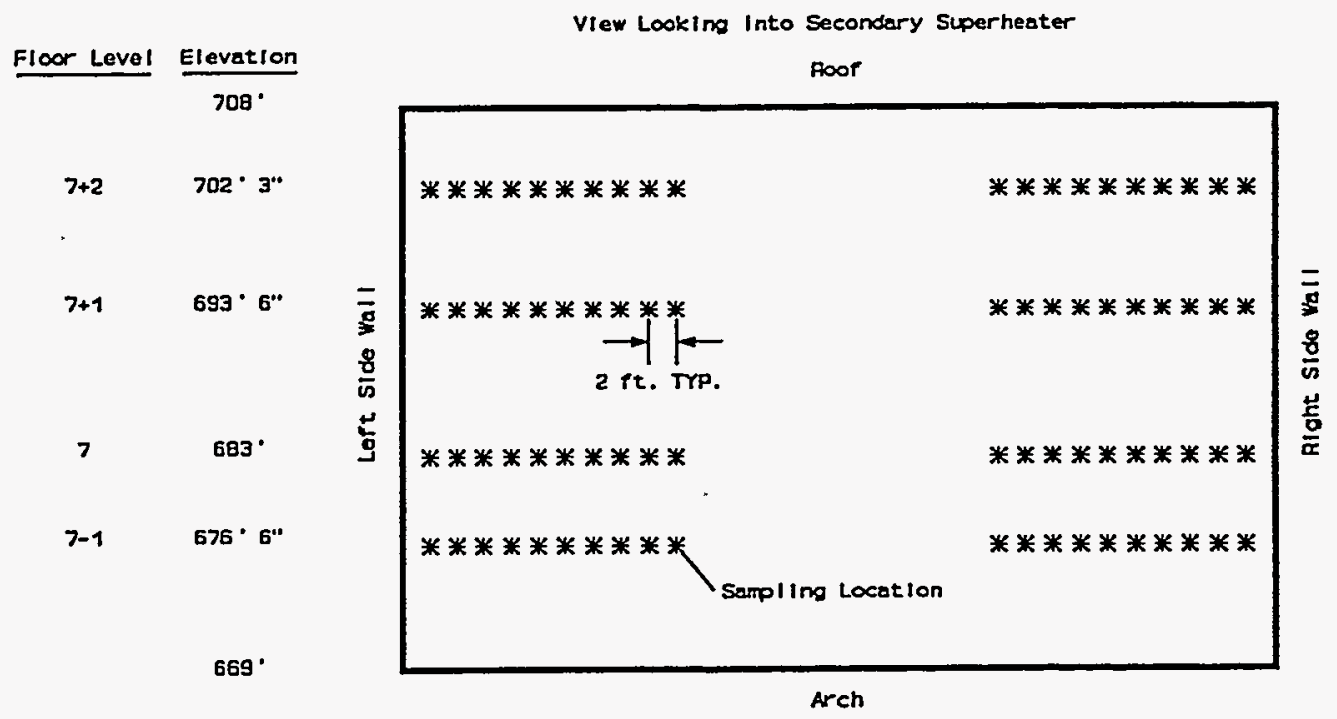

Figure 3-6 Furnace exit sampling locations 
Figure 3-7 shows the sampling locations at the plane 40 feet above the burners (elevation 636'-6"). The traverses for probing through the side walls were three feet from the centerline of the furnace toward the front wall. Measurements were made along two additional traverses through the rear wall about 18 inches from each side wall. All furnace openings that would accommodate probing were used at this elevation.

Full-scale utility boiler data sets that are reliable and detailed enough for comparisons with three dimensional numerical model predictions are extremely rare. Obtaining accurate data is difficult and costly. During the testing, the furnace probing was hindered by slag and ash plugging the HVT probe tip, especially at full load. Accuracy of the gas temperature, $\mathrm{O}_{2}$, and $\mathrm{CO}$ measurements depends on the cleanliness of the probe tip. The blockage formed gradually as the probe was retracted from the furnace at twofoot intervals. Temperatures measured with a partially plugged probe will be lower than the actual gas temperature. Consequently, the most reliable temperature measurements were those taken at locations farthest from the walls. The $\mathrm{O}_{2}$ and $\mathrm{CO}$ are less sensitive to the blockage as long as a sufficient volume of gas is provided to the analyzers. If severe plugging occurred, the suction pump that was used to extract gases for the gas analyzers began to intake the aspirating air stream. The resulting gas mixture to the analyzers was a mixture of flue gas from the furnace and the aspirating air. When the oxygen concentration increased unexpectedly, the probe was retracted from the furnace. The plugged tip was replaced, the probe was reinserted into the furnace, and testing resumed. The velocity measurements were obtained using the same probe. Total and static pressure taps were integrated into the design of the probe body, allowing the HVT probe to function as a Fechheimer probe as well. An air purge was applied through the pressure taps when no measurements were being taken to prevent slag and ash from clogging the pressure taps. Enough reliable velocity, temperature, $\mathrm{O}_{2}$, and $\mathrm{CO}$ data exist for detailed comparisons with the model predictions.

In many cases, boiler operating conditions are difficult to define completely enough to establish the neessary input for mathematial models. However, the boiler operating conditions during the testing were well defined and remained relatively constant during the probing. Even though the probing data do not

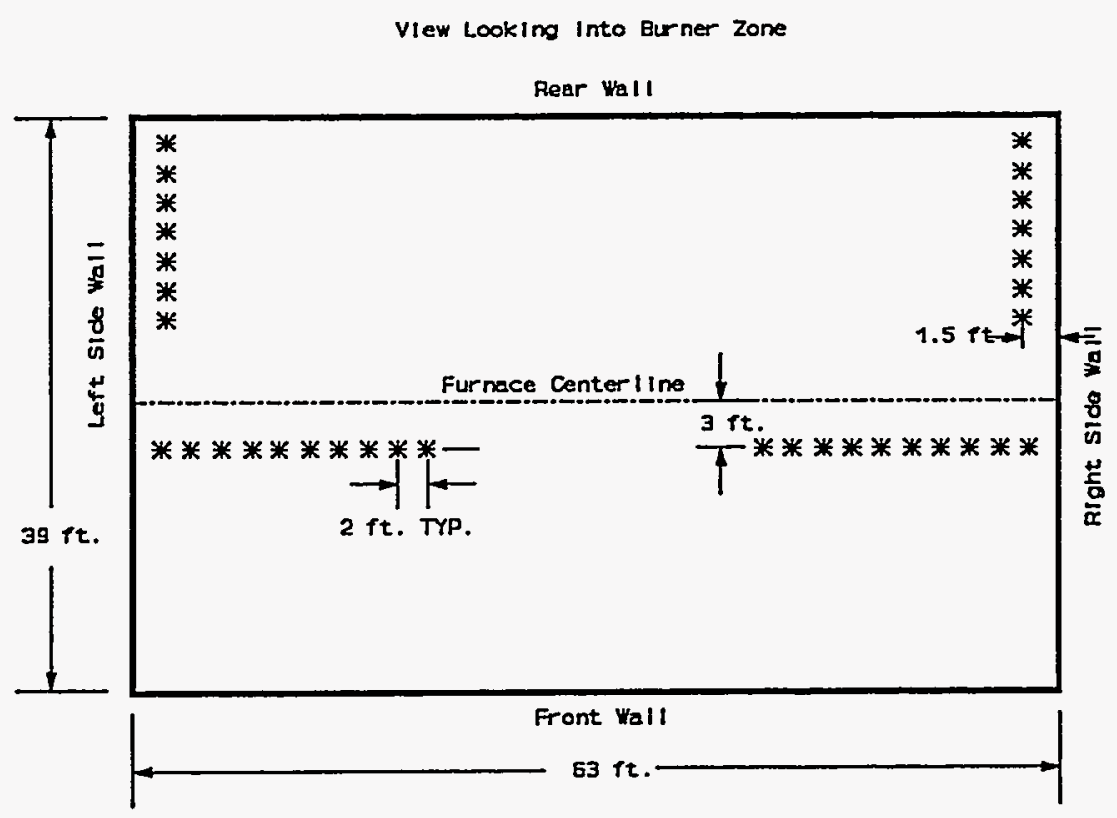

Figure 3-7 Sampling locations at a plane 40 feet above the burners 
provide a complete mapping of the measurement planes and may not be as reliable as those taken in a controlled laboratory environment, the full scale data sets are among the most extensive and reliable in existence. The well-defined sets of operating conditions for baseline and post-retrofit operation at two loads and the extensive in-furnace probing data make the test data well suited for comparison with numerical model predictions.

3.3.4 Gas Velocity Magnitudes. The same trends exist in the predictions and the data for baseline and post-retrofit operation. Both the predictions and the data indicated that the gas velocities at the furnace exit are higher near the arch than near the roof. No significant side-to-side flow upsets are indicated by the predictions or the data at the exit or 40 feet above the burners. The predicted distributions at intermediate load are not as uniform from side-to-side as at full load. The data indicated slightly more side-toside variation at intermediate load than at full load than the predictions did. The agreement between the predictions and data was generally better at intermediate load than at full load.

The flow near the arch and in the upper furnace is very complex. The local effect of the arch and the higher velocity flue gas flowing up the center of the furnace and turning $90^{\circ}$ to enter the convection pass result in a high velocity region near the nose of the arch. The agreement between the model predictions and the data is not expected to be as good in this complex flow region. The agreement may be improved by increasing the fineness of the computational grid (adding more control volumes) to the model in the upper furnace.

3.3.5 Gas Temperatures. For the baseline and post-retrofit tests at both loads, the predicted temperature distributions were more nonuniform than the actual distributions. The predicted temperatures at the plane 40 feet above the burners were higher than measured. The over-predicted temperatures indicate that the lower furnace heat absorption in the model may have been slightly low. Consequently, the predicted temperatures near the arch in the furnace exit plane were also higher than measured. The agreement between the predictions and data is slightly better at intermediate load than at full load. Some side-to-side variation was predicted and measured at the furnace exit and at the plane 40 feet above the burners. An inherent asymmetry in the furnace exists due to the alternating cell inversion.

3.3.6 Oxygen Concentrations. The predicted and measured $\mathrm{O}_{2}$ concentrations at the furnace exit were more uniform for baseline operation than for post-retrofit operation at full and intermediate loads. Non-uniformities is more noticeable with the chemical species, like $\mathrm{O}_{2}$, than with the velocity or temperature predictions. Both the predictions and the data indicated that the oxygen concentrations were higher near the front wall and in the upper half of the furnace exit plane with Mill A out of service at intermediate load. With Mill A out of service, the four outer cells in the upper row on the front wall are out of service at intermediate load (see Figure 3-3). Since the secondary air flow to the out of service cells was essentially the same as the in service cells, high $\mathrm{O}_{2}$ concentrations exist near the front wall. Most of the $\mathrm{O}_{2}$ remains near the front wall as it passes up the furnace causing the higher concentrations in the upper section of the furnace exit plane.

3.3.7 Carbon Monoxide Concentrations. The comparison of predicted and measured CO concentrations for the baseline modeling were not included in the baseline test report. The predicted and measured baseline $\mathrm{CO}$ concentrations are presented here along with the post-retrofit results for comparison.

The model predictions are compared graphically to the $\mathrm{CO}$ data. Baseline and post-retrofit results are presented in the same figures. The data have been plotted on contour plots of the predictions. The 
contours and circles marking the sampling locations have been shaded according to the legend in each figure. The contour lines have been labeled to facilitate comparisons with measurements listed at the sampling locations. Average values are listed for repeated measurements at the same location. At the furnace exit plane, the reader's view is into the convection pass from the furnace. At the plane 40 feet above the burners, the reader's view is into the burner zone from above.

The predicted $\mathrm{CO}$ concentrations for full load at the plane 40 feet above the burners are compared with data in Figure 3-8. The baseline predictions and data agree very well. The post-retrofit agreement is reasonably good except in the left rear corner. The predictions indicate that zones of high $\mathrm{CO}$ exist near the front and rear walls. The predicted locations of the high $\mathrm{CO}$ regions may be slightly different than the actual locations in the furnace, which may account for the differences in the left rear corner. The predictions and data at the furnace exit are compared in Figure 3-9. The predictions and limited amount of data agree well for the baseline except near the arch where the measured $\mathrm{CO}$ is much lower than the predictions. The post-retrofit predictions and data agree reasonably well, except for two regions where the $\mathrm{CO}$ data exceeds $1000 \mathrm{ppm}$ (Floor 7 - left side wall and Floor $7+1$ - right side wall). The source of the high $\mathrm{CO}$ in the exit plane may be localized regions in the furnace flow field that contain high $\mathrm{CO}$ concentrations but limited oxygen, like those predicted along the front and rear walls. As the flow passes the arch and turns to exit the furnace, these localized regions mix with the surrounding flow that contains excess oxygen.

The measured $\mathrm{O}_{2}$ ranges from $1.2 \%$ to $2.6 \%$ at the locations in the furnace exit plane where $\mathrm{CO}$ concentrations greater than $1000 \mathrm{ppm}$ were measured. The $\mathrm{CO}$ should convert rapidly to carbon dioxide $\left(\mathrm{CO}_{2}\right)$ with the high temperatures and the availability of excess oxygen.

The predicted $\mathrm{CO}$ concentrations for intermediate load at the plane 40 feet above the burners are compared with data in Figure 3-10. The baseline predictions did not exceed about $80 \mathrm{ppm}$, while some of the data exceeded $800 \mathrm{ppm}$. The lack of agreement is likely due to the high excess $\mathrm{O}_{2}$, the burners out of service, and the assumption of uniform air distribution to the burners. The assumption that the air entered equally through all of the cell burners caused the model to predict complete combustion at a point lower in the furnace than if some burners received less air, delaying the combustion until higher in the furnace. The air distribution to the burners was better defined for the post-retrofit modeling because the air measuring devices indicated any imbalance of air flow and the sliding air dampers provided any additional pressure drop needed to balance the air flow. The agreement between the predictions and data is better. However, the model tends to under-predict $\mathrm{CO}$ concentrations in oxidizing regions with high $\mathrm{O}_{2}$ levels. The predictions and data at the furnace exit, shown in Figure 3-11, also show that the $\mathrm{CO}$ concentrations are under-predicted for the baseline and for the post-retrofit in the left side of the furnace exit plane. However, the agreement is reasonably good on the right side of the exit plane. The post-retrofit data indicate that the high $\mathrm{CO}$ concentrations on the left side of the exit plane exist for both full and intermediate loads. Although not possible to obtain, a more detailed mapping of the plane 40 feet above the burners could help to explain the origin of the high $\mathrm{CO}$ concentrations at the furnace exit. 


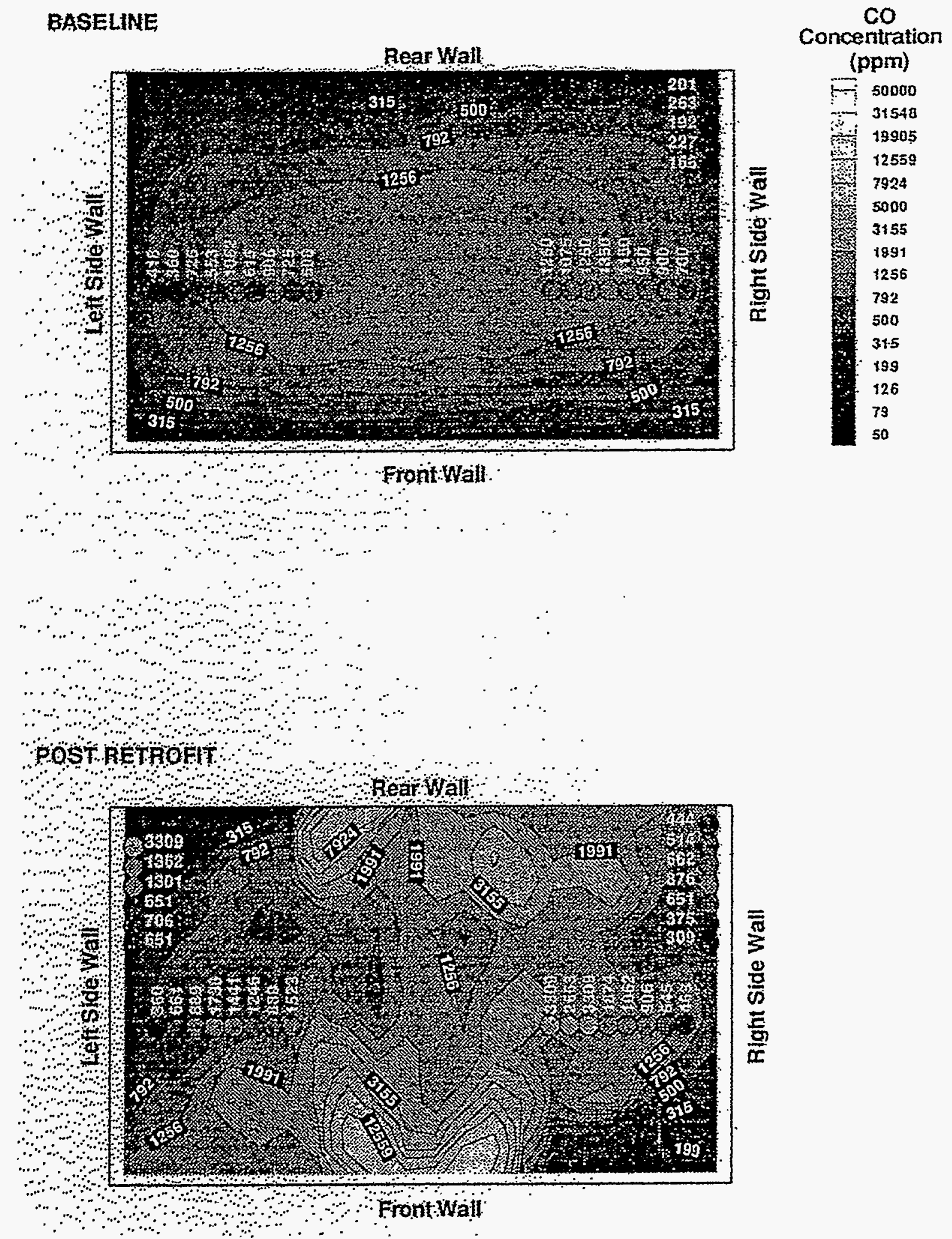

Figure 3-8 CO concentrations for full load -40 feet above the burners 


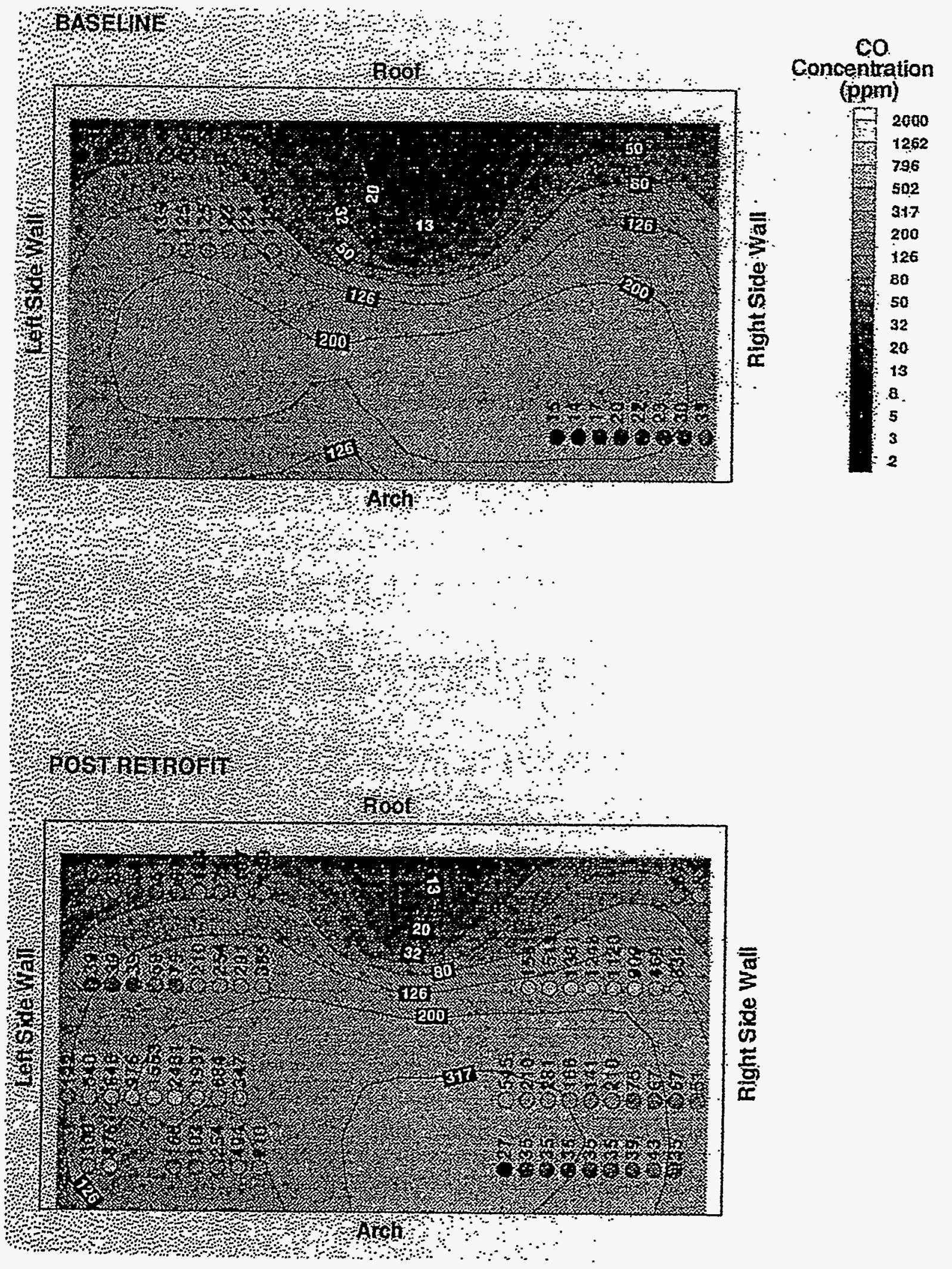

Figure 3-9 CO concentrations for full load - furnace exit 


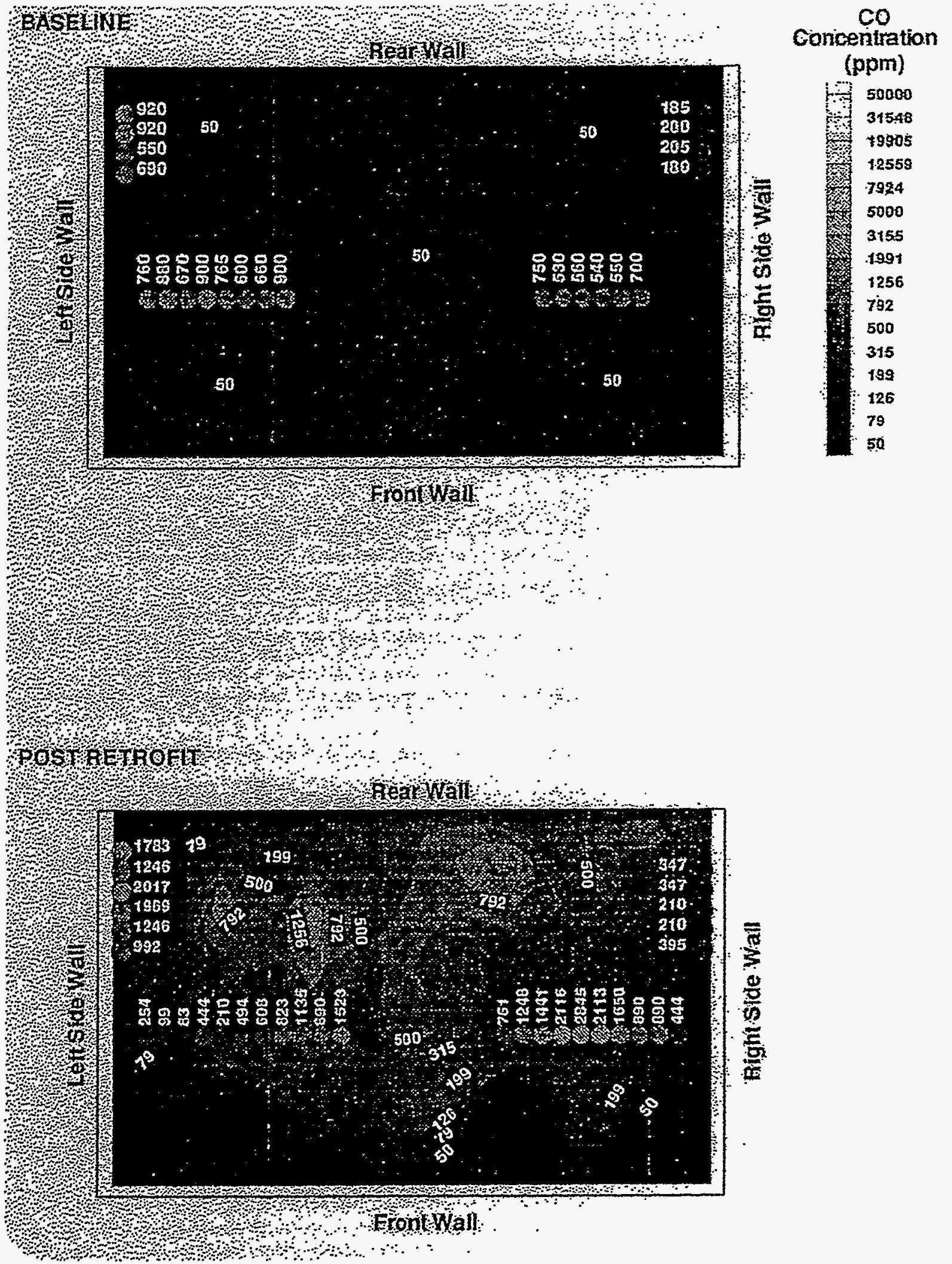

Figure 3-10 CO concentrations for intermediate load -40 feet above the burners 


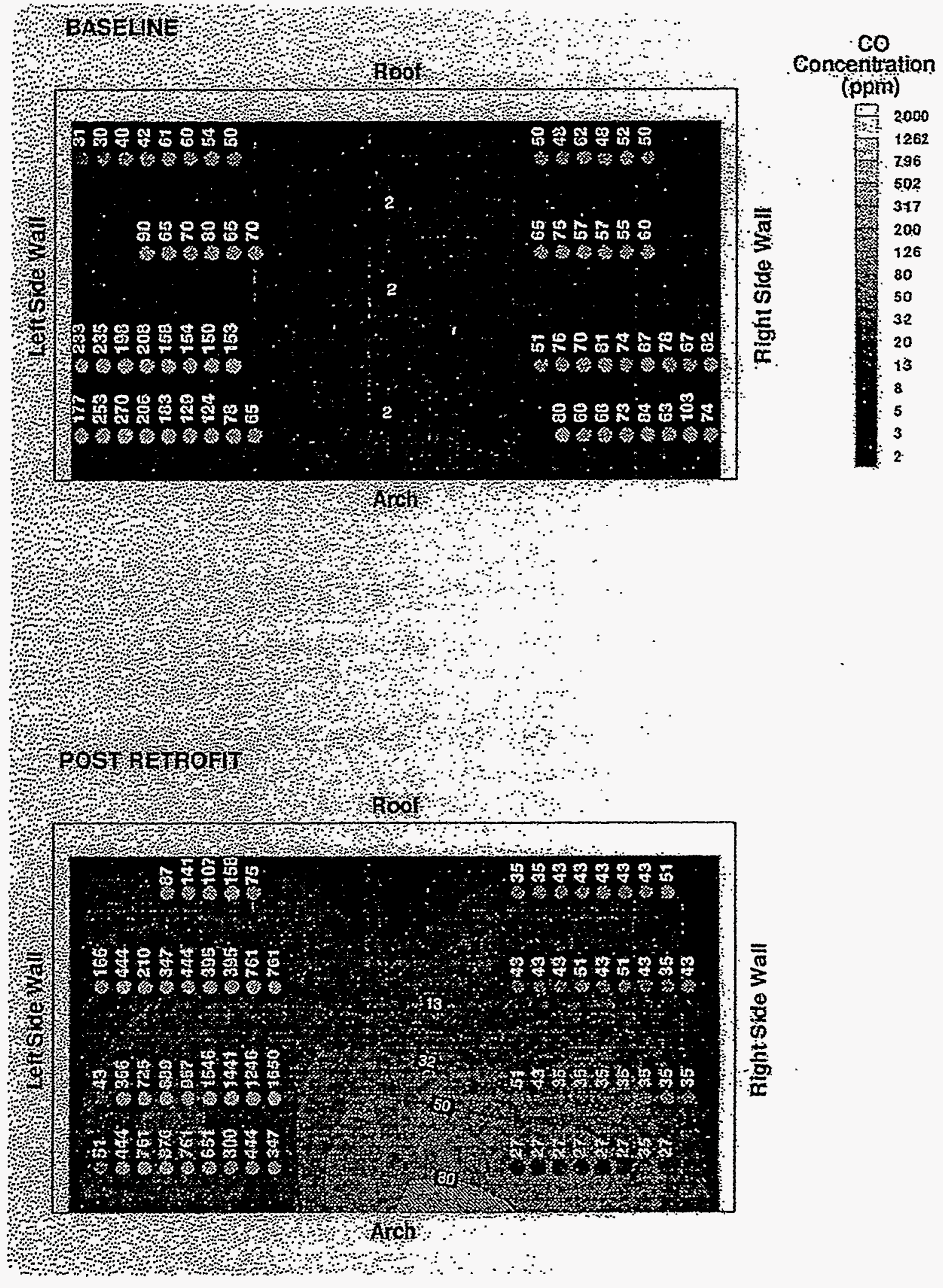

Figure 3-11 CO concentrations for intermediate load - furnace exit 


\subsection{Conclusions}

Because the operating conditions during baseline testing were well defined and extensive measurements were made at the furnace exit and at a plane 40 feet above the burners, the data are well suited to be used for comparison with numerical model predictions.

Based on the $\mathrm{CO}$ mitigation studies, the numerical model can reliably predict the overall impact of various burner arrangements on the furnace flow, combustion, and heat transfer.

The agreement between the predictions and the data is qualitatively very good. The numerical model predictions and the data show the same trends about the operation of JMSS4 during baseline and postretrofit testing. B\&W's numerical models will be useful as utility boiler evaluation tools.

\subsection{Recommendations}

B\&W's numerical models should be used to characterize the performance of full-scale utility boilers equipped with $\mathrm{LNCB}^{\mathrm{TM}}$ burners. The models can predict boiler performance and emissions prior to the costly expenditure of a complete boiler retrofit.

Some of the modeling predictions require additional evaluation. The disparity between the predicted and measured gas velocity magnitudes near the arch at the furnace exit, the lower furnace heat absorption, and the furnace exit $\mathrm{CO}$ concentrations should be investigated. These disparities will be addressed on subsequent company-funded research projects. The sensitivity of the baseline predictions to the assumption of uniform air and coal distribution between burners should be further evaluated. The overall agreement between the predictions and the data is expected to be better with a more refined computational grid. 


\section{Section 4 \\ LNCB $^{\text {TM }}$ BURNER DESIGN REVIEW}

\subsection{Low-NO Cell $^{\mathrm{TM}}$ Burner Hardware}

In the $\mathrm{LNCB}^{\mathrm{TN}}$ burner arrangement, all the coal is supplied to one burner throat with a portion of the total required secondary air. The coal piping for a standard burner cell is altered to supply all of the coal to this burner throat via a " $Y$ " connection. The burner assembly is essentially a conventional S-type burner, sharing functional attributes of the circular burner in an improved configuration. A larger coal nozzle is installed in the burner throat which is essentially twice the area of that for standard cell burners. The larger coal nozzle has an impeller to radially disperse the coal/air mixture at the burner exit. The angle of dispersion, set by the shape of the impeller, determines the flame shape and length which have a direct impact on $\mathrm{NO}_{\mathrm{x}}$ formation and reduction. A regulating rod is attached to the impeller to permit adjustment of its location.

The balance of secondary air is supplied to a $\mathrm{NO}_{\mathrm{x}}$ port adjacent to the burner. The $\mathrm{NO}_{\mathrm{x}}$ port is equipped with a sliding disk to control air flow, a Pitot tube grid to measure air flow, and louvers at the outlet to control mixing of the air stream with the flame. The secondary air quantity for burner stoichiometry is determined by the sliding disk as it moves to or away from the burner barrel. The sliding dampers have three preset positions for operation, i.e., out-of-service cooling position, burner light-off position, and normal operating position. The secondary air swirl for flame shaping is provided by adjustable spin vanes positioned in the burner barrel. An air measuring Pitot tube grid is installed in the barrel ahead of the spin vanes. The spin vane-Pitot tube combination ensures that secondary air is uniformly distributed among the burners.

\subsection{Mechanical Modifications}

The LNCB ${ }^{\mathrm{TM}}$ burners were installed in J. M. Stuart Station \#4 (JMSS4) in the Fall of 1991. During the preliminary post-retrofit testing, the needs for two $\mathrm{LNCB}^{\mathrm{TM}}$ design changes were identified. The first change involved replacement of 24 burner impellers. The best $\mathrm{NO}_{\mathrm{x}}$ reduction obtainable with the original impeller configuration was only $35 \%$. Pilot-scale testing and simulated testing at JMSS4 indicated that a more shallow angled impeller was needed to achieve the project goal of $50 \% \mathrm{NO}_{\mathrm{x}}$ reduction.

The second design change involved alternative inversion of the bottom two opposed rows of LNCB ${ }^{\mathrm{TM}}$ burners. This change was required due to the high $\mathrm{CO}$ and $\mathrm{H}_{2} \mathrm{~S}$ concentrations detected in the furnace hopper. JMSS4 is a pressurized unit. Therefore, if high $\mathrm{CO}$ and $\mathrm{H}_{2} \mathrm{~S}$ concentrations are present, they pose a hazard when gas leaks develop. In addition, the reducing atmosphere would promote accelerated corrosion on the hopper tubes. Sub-stoichiometric operation of the $\mathrm{LNCB}^{\mathrm{TM}}$ burners was apparently responsible for the situation.

B\&W used the 3-D numerical modeling programs, as described in Section 3, to simulate furnace conditions with the initial $\mathrm{LNCB}^{\mathrm{TM}}$. configuration which substantiated the high $\mathrm{CO}$ conditions measured in 
JMSS4. Using the same modeling approach, several alternative burner $/ \mathrm{NO}_{\mathrm{x}}$ port arrangements that could mitigate the problem were also explored. The computer analysis identified that the optimal solution was inversion of every other $\mathrm{LNCB}^{\mathrm{TM}}$ burner on the bottom burner level (Figure 4-1).

4.2.1 Implementation of Mathematical Modeling. The objective of mathematical modeling was to evaluate strategies for reducing $\mathrm{CO}$ concentrations and to assess their impact on unit performance. To mitigate $\mathrm{CO}$, a method that would inject air into the furnace hopper without any pressure part modifications, substantial cost, or loss of unit efficiency was desired. Therefore, $\mathrm{CO}$ mitigation strategies included 1) modifying the burner and $\mathrm{NO}_{\mathrm{x}}$ port flow control settings with the existing installation and 2) inverting selected lower row burners.

4.2.1.1 Initial Unit Operation. CO mitigation strategies were evaluated at full and reduced loads with various mills out of service. All the modeling results presented here are for full load operation with all mills in service. The following conditions were used to model "normal operation" with the LNCB" burners:

- Burner stoichiometry

- Total excess air at the economizer outlet

- Burner secondary air zone vane position

- Air port louver dampers
-0.6 .

$-22 \%$.

$-60^{\circ}$ from closed.

$-+7^{\circ}$ (angled up).

Any variation in these operating conditions were noted. The original arrangement of burners and $\mathrm{NO}_{\mathrm{x}}$ ports are shown in Figure 1-3. In that arrangement, all burners were positioned in the lower cell openings and all $\mathrm{NO}_{\mathrm{x}}$ ports in the upper cell openings.

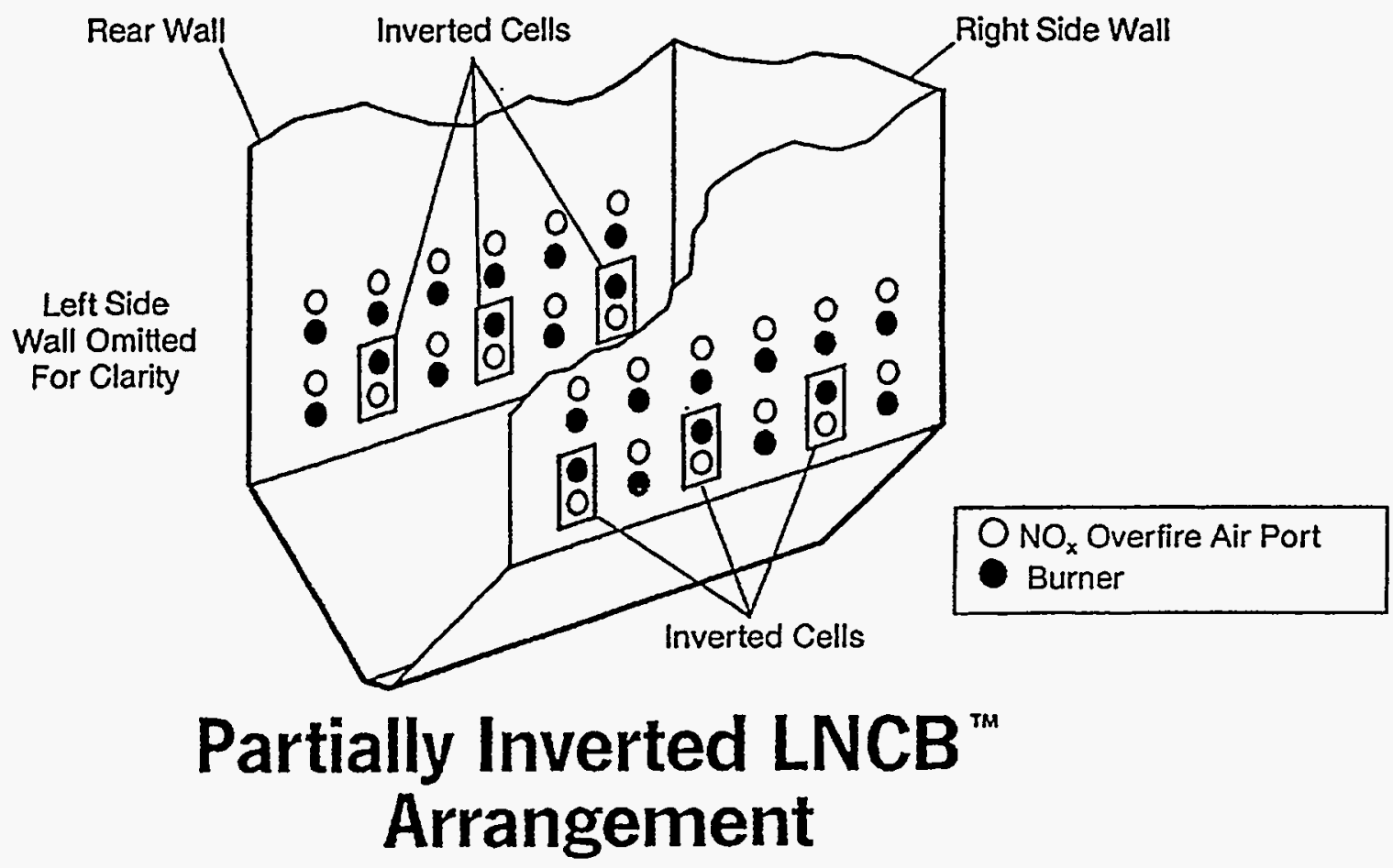

Figure 4-1 Final burner and $\mathrm{NO}_{\mathrm{x}}$ port locations 
High CO concentrations were measured shortly after the unit startup of the retrofit $\mathrm{LNCB}^{\mathrm{TM}}$ burners configured in the manner described above. Figure 4-2 shows the predicted $\mathrm{CO}$ levels near the right side wall of JMSS4. The shading indicates variation in the CO concentrations. The contour interval is 10,000 ppmV. The cross-hatched areas refer to the CO concentrations less than $10,000 \mathrm{ppmV}(1 \%)$, and the black indicates $120,000 \mathrm{ppmV}$ or higher $(+12 \%)$.

With this original $\mathrm{LNCB}^{\mathrm{TM}}$ burner arrangement under normal operation, $\mathrm{CO}$ concentrations along the right side wall below the hopper work point were all higher than $100,000 \mathrm{ppmV}$. This plane was representative of the entire boiler width. The $\mathrm{CO}$ measurements were made at an elevation approximately halfway between the hopper throat and the hopper work point at the centerline of the furnace as shown in Figure 4-2. Measured concentrations at this location were between 100,000 and $120,000 \mathrm{ppmV}$ for normal operation, which supported previous predictions.

4.2.1.2 Model Design Variations. The $\mathrm{NO}_{\mathrm{x}}$ port louver dampers in the lower row of the burners were adjusted at $-20^{\circ}$ (downward) to direct more air into the hopper. Predicted $\mathrm{CO}$ concentrations in the hopper actually increased with this setting (i.e., 140,000 to $150,000 \mathrm{ppm}$ as shown in Figure 4-2). Results suggested that angling the air flow $20^{\circ}$ downward actually forced more sub-stoichiometric combustion gas into the oxygen deficient hopper. Later measurements taken during operation with a similar $\mathrm{NO}_{\mathrm{x}}$ port louver damper setting showed $130,000 \mathrm{ppm} \mathrm{CO}$. Therefore, both predicted and measured data indicated an increase in the $\mathrm{CO}$ concentrations by this adjustment.

Other variations of burner operational parameters were attempted to instigate $\mathrm{CO}$. The stoichiometry of burners in the lower row of cells was increased from 0.6 to 0.8 and the louver dampers set to $+7^{\circ}$ (upward). The total excess air to the unit was not increased. With this setting, the predicted $\mathrm{CO}$ concentrations decreased, as expected, with the increased burner stoichiometry, but only to about $60,000 \mathrm{ppm}$ (Figure 4-2). Later measurements confirmed CO concentrations of 50,000 to $60,000 \mathrm{ppm}$ in the hopper region. Therefore, variations in the burner and $\mathrm{NO}_{\mathrm{x}}$ port flow control settings were not effective in reducing the high $\mathrm{CO}$ to an acceptable level. However, the excellent agreement between predicted values and measured data has demonstrated the reliability of numerical modeling. Consequently, the models were used to evaluate $\mathrm{CO}$ concentrations with selected inversion of lower row burners.

Inversion of the outer cells (four total) would have reduced $\mathrm{CO}$ along the side walls, but concentrations would still be above 120,000 ppm in the remainder of the hopper, as shown in Figure 4-3. Inverting the outer two burners near each side wall (eight total) would have given similar results. Inversion of the entire lower row of burners on the front and rear walls would have reduced the $\mathrm{CO}$ concentrations to a few hundred ppm, but the furnace heat absorption patterns would have changed dramatically, and the FEGT would have also increased by approximately $90^{\circ} \mathrm{F}$.

4.2.1.3 Modeling Solution. The model results showed that inversion of every other $\mathrm{LNCB}^{\mathrm{TM}}$ burner in the lower rows was found effective in mitigating the high $\mathrm{CO}$ concentrations in the hopper. Figure 4-4 shows that $\mathrm{CO}$ concentrations along the right side wall and in the entire hopper are less than $10,000 \mathrm{ppm}$. In fact, $\mathrm{CO}$ levels were under $1000 \mathrm{ppm}$, which became comparable to the pre-retrofit levels. The alternating inversion was also evaluated at reduced loads with various mills out of service. Regardless of the loads or mills out of service, $\mathrm{CO}$ levels in the hopper were comparable to those during the baseline operation. No changes in the furnace heat absorption patterns were predicted with the alternating inversion. Calculated FEGT increased by $5^{\circ} \mathrm{F}$ at full load relative to that of pre-inversion operation. 
Normal Operation

\section{Right SIde Wall}
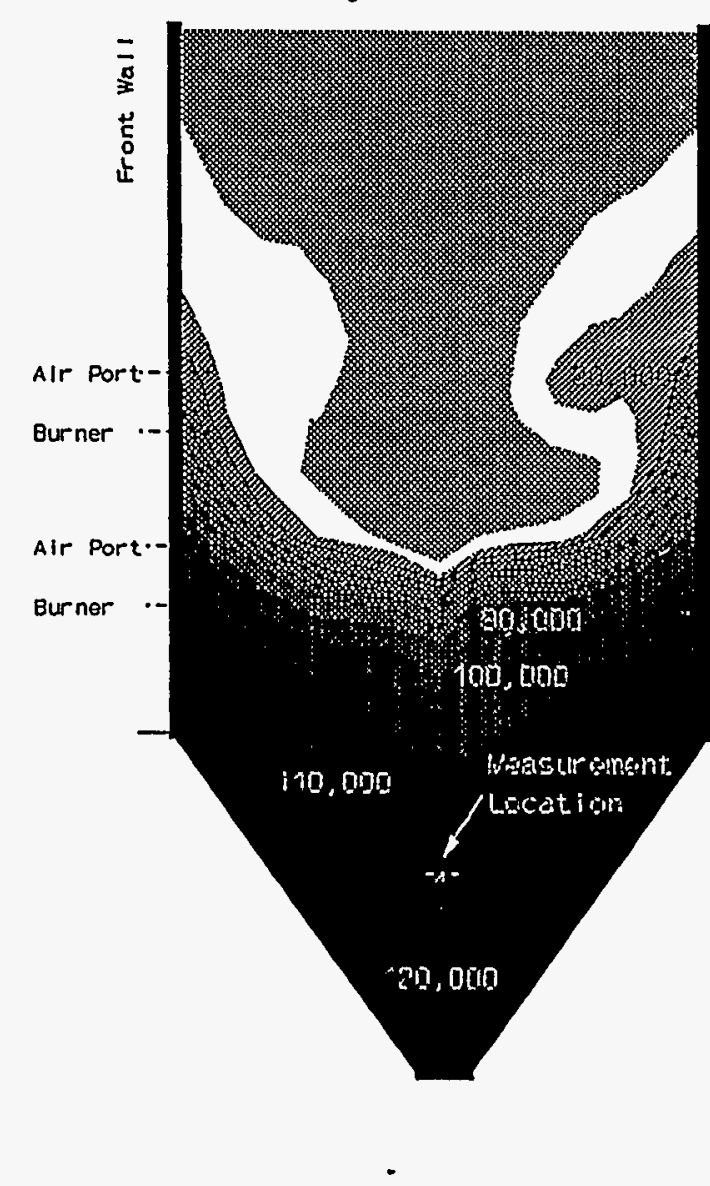

$100,000-120,000$ ppmv
Air Port Dampers

20 degrees Down

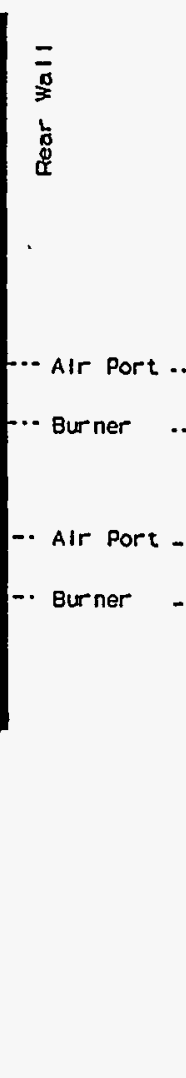

Measured CO Concentrations

130, $000 \mathrm{ppmV}$
Lower Row Burner

Stoichiometry 0.8
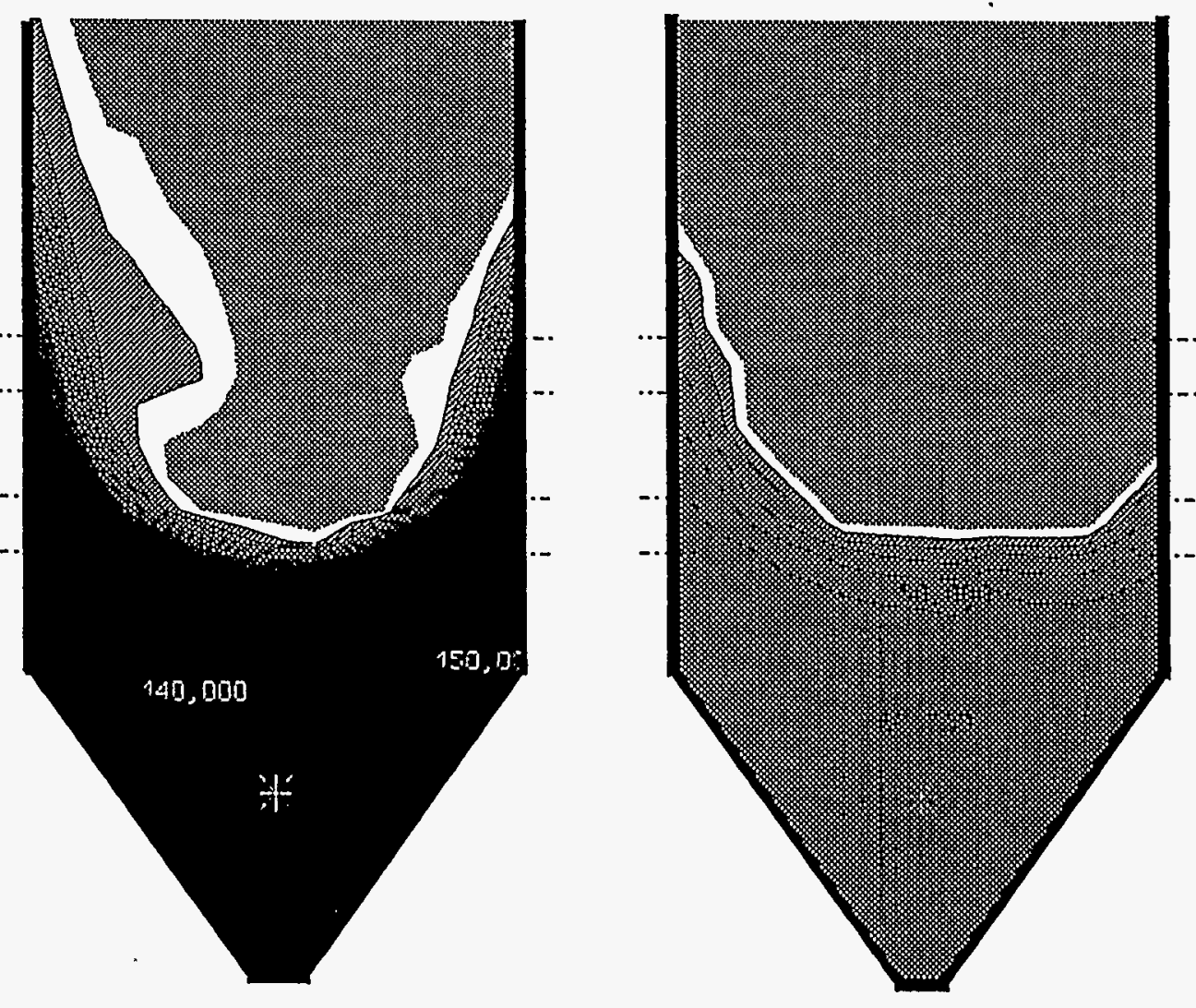

$50,000-60,000$ ppmV
Concentration (ppm)

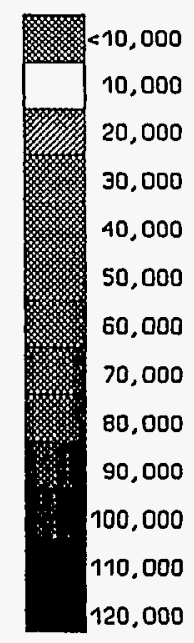

120,000

Figure 4-2 Predicted CO concentrations 


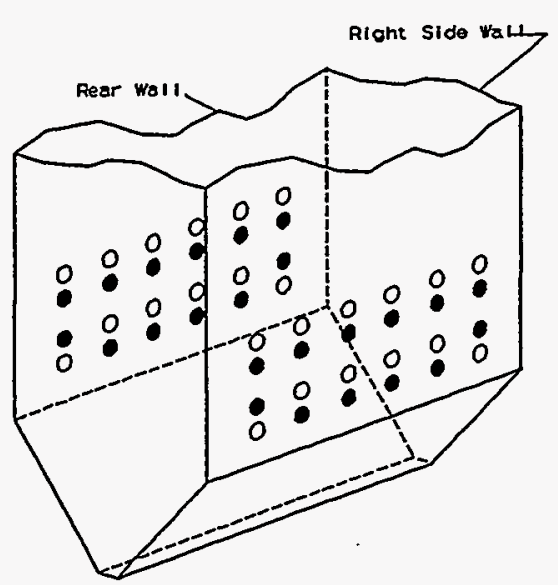

Concentration

$<10,000$

10.000

20,000

30,000

40.000

50,000

50,000

70.000

80.000

90. 000

100,000

170,000

120. 000
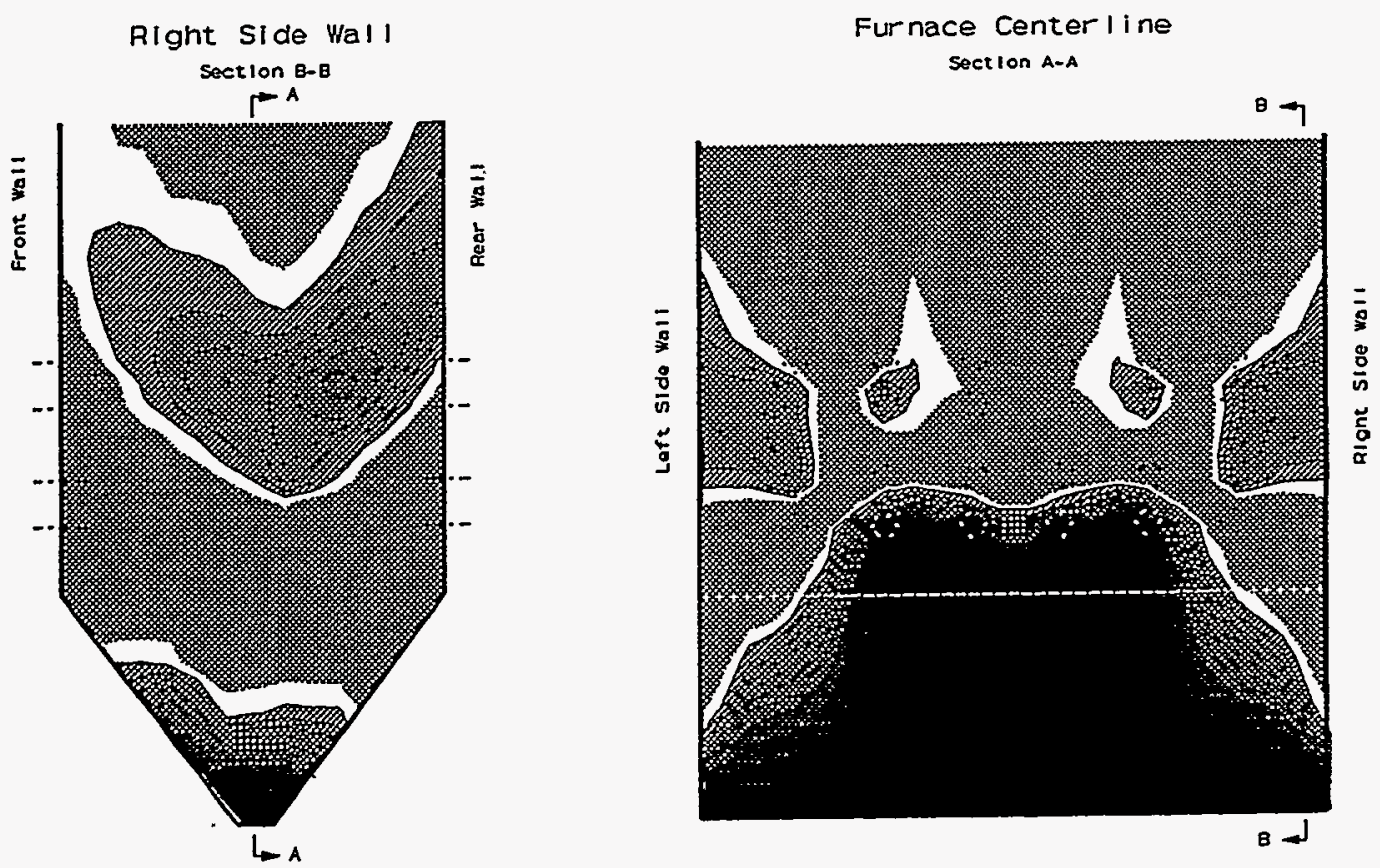

Figure 4-3 Outer cells inverted 

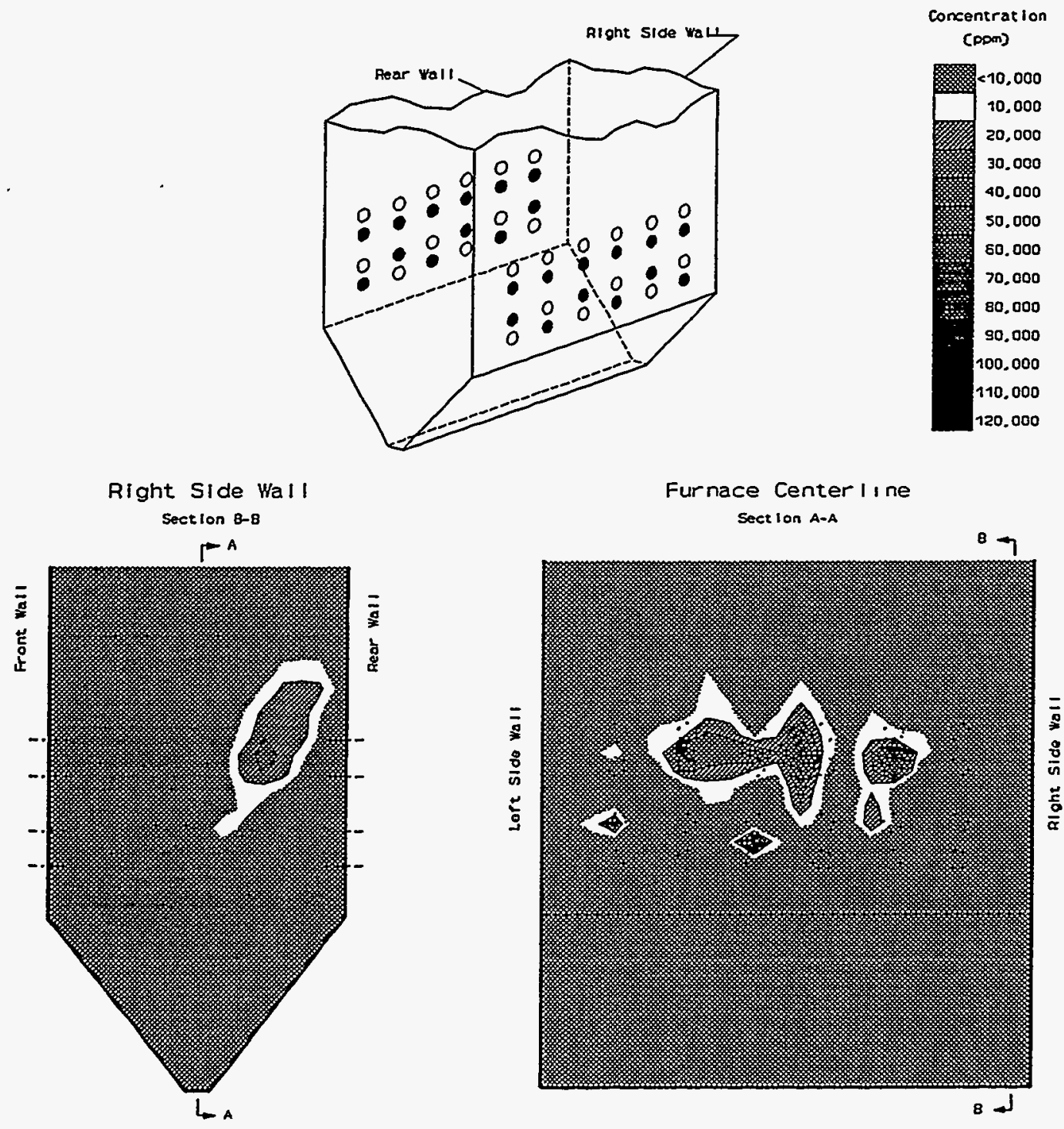

Figure 4-4 Alternating lower cell inversion 
4.2.2 Modeling Summary. Modeling results indicated that changes of the flow controls of the burners and $\mathrm{NO}_{\mathrm{x}}$ ports could not significantly lower the $\mathrm{CO}$ concentrations in the hopper. However, inverting all or alternating $\mathrm{LNCB}^{\mathrm{TM}}$ burners in the lower row reduced $\mathrm{CO}$ concentrations to a level comparable to that of pre-retrofit operation. Additionally, the inversion required no changes to the boiler pressure parts. Inversion of every other lower row burner was the best strategy that would not notably alter the FEGTs or furnace heat absorption patterns.

\subsection{Control System Modifications}

To accommodate the LNCB ${ }^{\mathrm{TM}}$ burner retrofit, the electrical and control systems of JMSS4 needed to be modified to accept the 48 new sliding air damper drives. Each of the LNCB $^{\mathrm{TM}}$ burners had two sliding air damper drives - one on the burner throat and one on the $\mathrm{NO}_{\mathrm{x}}$ port. Limit switches were provided to stop the drive motor at the preset positions for out-of-service cooling, burner light-off, and normal operation. A control signal (momentary pulse) was used to start the drive motor and advance (or retract) the air damper to the next position in sequence. Operation of the drives on the burner and $\mathrm{NO}_{\mathrm{x}}$ port portions coincided with each other. Pushbuttons mounted in the control room provided the control signal to the motor starters (mounted in the motor control center) for the drives. The control signals were interlocked with the pulverizer and burner management control systems.

The old control system prior to retrofit consisted of a total of 24 air register drives, each controlling a pair of burner air registers. Control of the air registers was operator initiated (i.e., not part of an automated burner control system). Drive commands were sent by the operator via pushbuttons to position registers in the closed, light-off, or open position from the control room. Operating limits and the operator's feedback panel came from a 13-position limit switch in each Limitorque air register drive.

There were some operating limits and permissions associated with the old register control system, such as air register positioning - closed with the coal feeder in service, in the light-off position to allow starting of the igniters, open for purge, etc.

A total of 48 air register drives were installed during the retrofit - one for each burner and $\mathrm{NO}_{\mathrm{x}}$ port. Control of the new air registers was essentially the same as during pre-retrofit operation. The only exceptions were that Dayton Power \& Light (DP\&L) added local pushbuttons near the burners. These pushbuttons helped assure that the registers were in the proper position for boiler purge.

The new drives furnished had four position switches, compared to 13 in the old ones. In order to minimize the installation costs and achieve a high degree of reliability, a programmable logic controller (PLC) was included to interface the old operator pushbutton system with the new drive position switches. This interface allowed for register drive control and provided the operator with limited number of position switches.

The PLC also reduced field installation time and costs compared to those of many relays required to accomplish the same control scheme. By using the PLC, it was possible to move some of the logic into the PLC and therefore, eliminated the need for respective mechanical relays. One PLC was used for each set of pulverizer air registers (i.e., six PLCs total). PLC programming was performed by DP\&L. 


\subsection{General Installation}

The $\mathrm{LNCB}^{\mathrm{TM}}$ burner is a plug-in modification consisting of the following equipment:

- Burner portion of LNCB

- $\mathrm{NO}_{\mathrm{x}}$ port portion of LNCB

- Ceramic-lined coal elbow

- Ceramic-lined and non-ceramic fuel-air piping and supports

- Air zone disk drives

- 24-inch O.D. slide gate valve

- Burner wallbox

- Coal pipe restrictors

- $\mathrm{LNCB}^{\mathrm{TM}}$ thermocouples

- Magnehelic gages

- Miscellaneous platform modifications

- Control system modifications

DP\&L was faced with the task of coordinating the removal of 24 two-nozzle cells (12 each on the front wall and rear wall) and installation of the above equipment during a six-week turbine outage. This work was concurrently done with the installation of a new furnace hopper floor and complete replacement of the secondary superheater outlet bank and headers. To ensure success of the entire outage, DP\&L followed the installation timeline schedule shown in Table 4-1. Figures 4-5 through 4-13 show several stages of the retrofit work.

4.4.1 Pre-Outage Work. A key to the outage's success was extensive planning, equipment staging at or near the work location, and performance of pre-outage tasks. This work included preassembly of equipment, the addition of a monorail system to remove old equipment and install new equipment, and addition of lifting lugs to major components for easier handling.

4.4.2 Outage and Post-Outage Work. Outage work included removal of old coal piping and burners, installation of $\mathrm{LNCB}^{\mathrm{TM}}$ burners, installation of coal pipes and resistor sleeves, and installation of control system equipment. Post-outage work included lagging installation, pressure gages and completion of platform alterations. Refer to the sequence of photos for general information on the LNCB ${ }^{\mathrm{TM}}$ burner installation.

\subsection{Startup}

LNCBTM burner startup followed the same procedures and progressed much the same as a cell burner startup with the only difference being that the burner dampers instead of having two positions (open or closed), now had three positions (closed, lightoff, and open). The LNCB ${ }^{\mathrm{TM}}$ burner was as easy to lightoff and operate as the cell burners they replaced. 


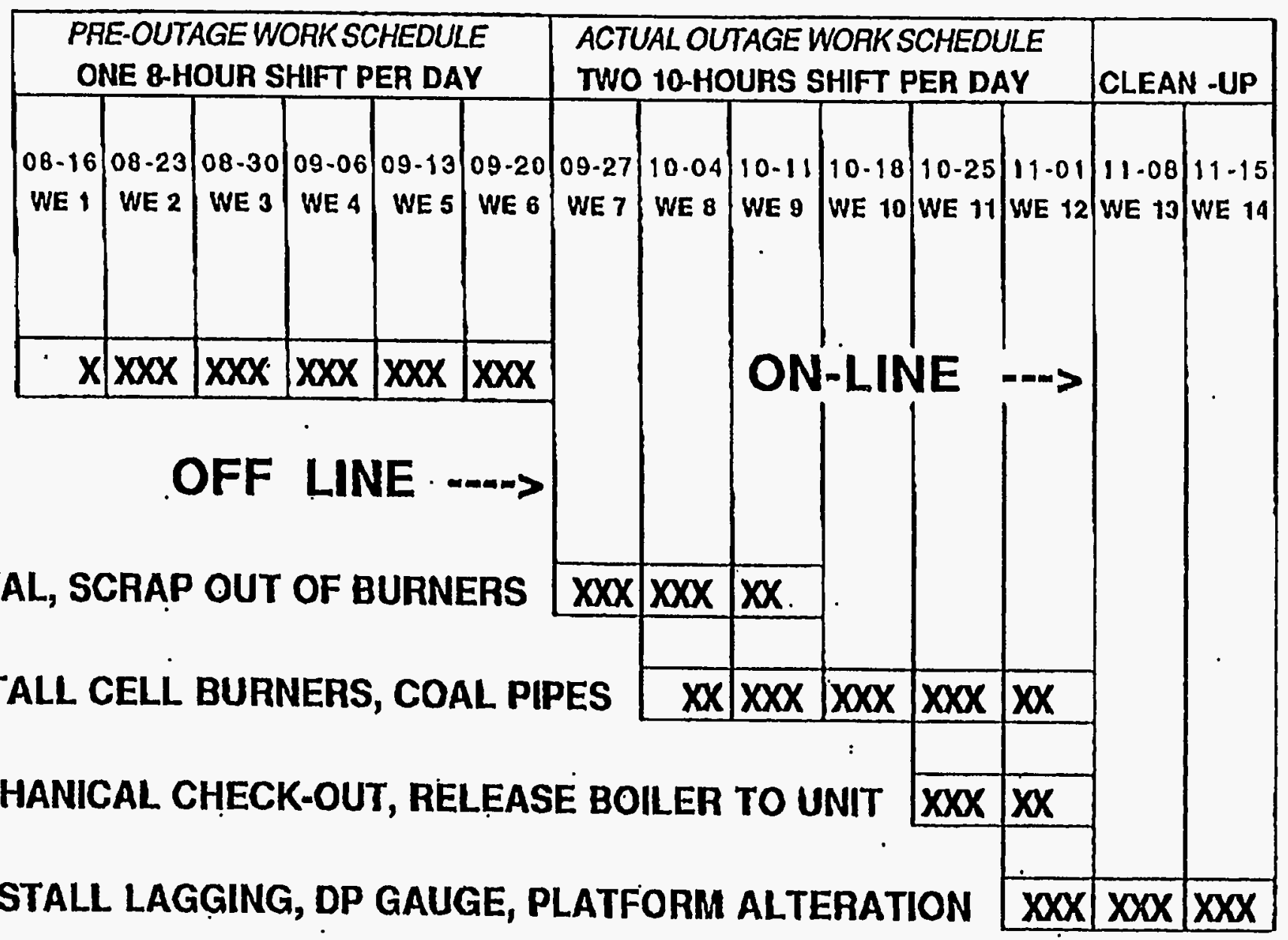




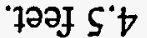

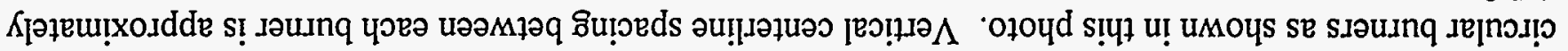

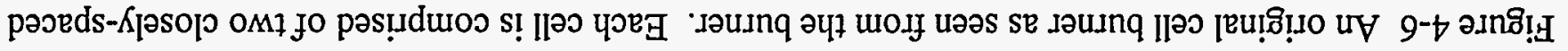

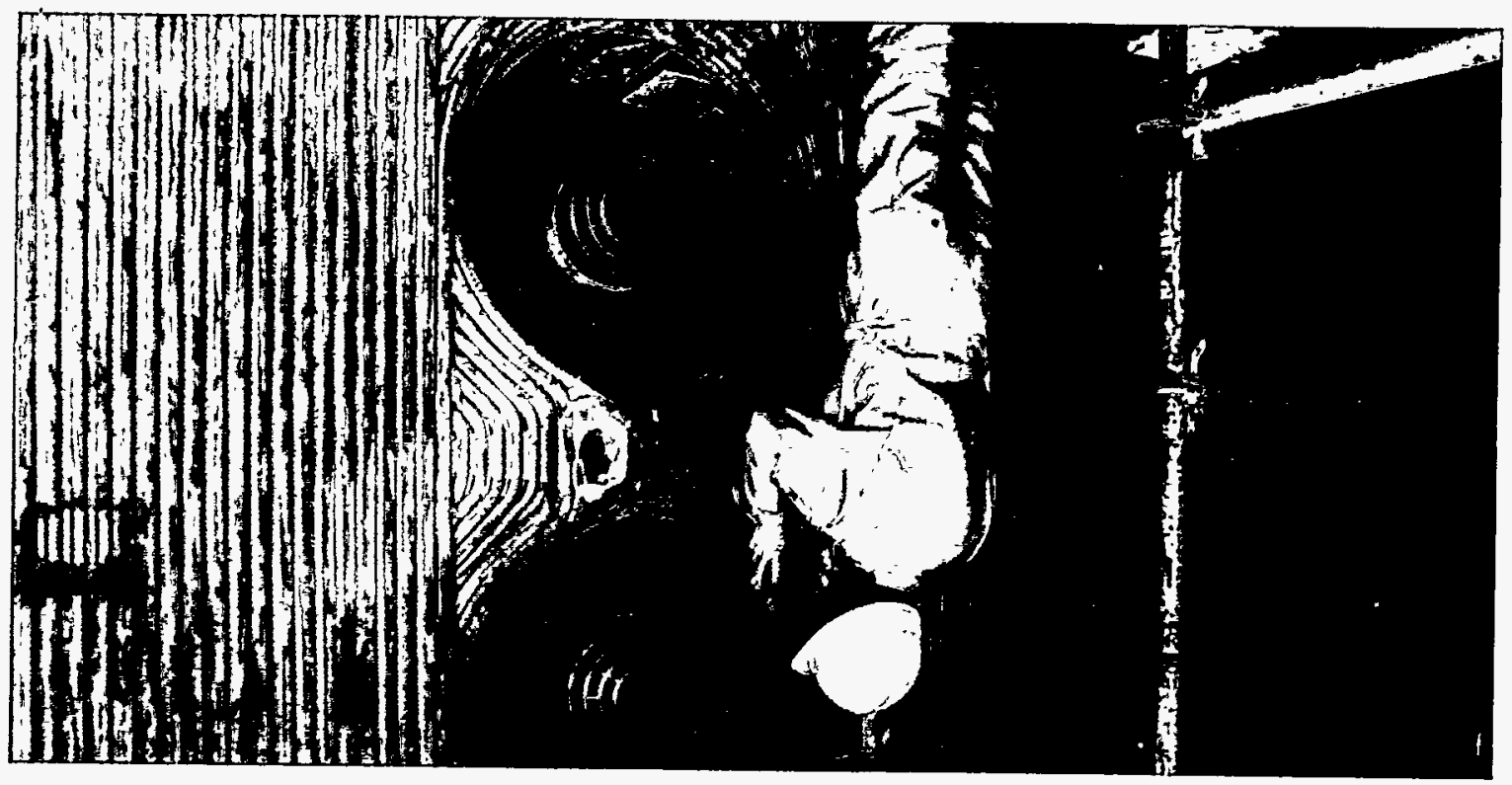

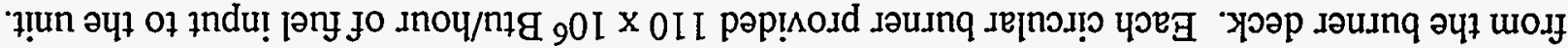
uəəs se ədịd ןeoว [enp!

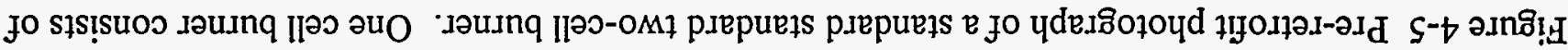

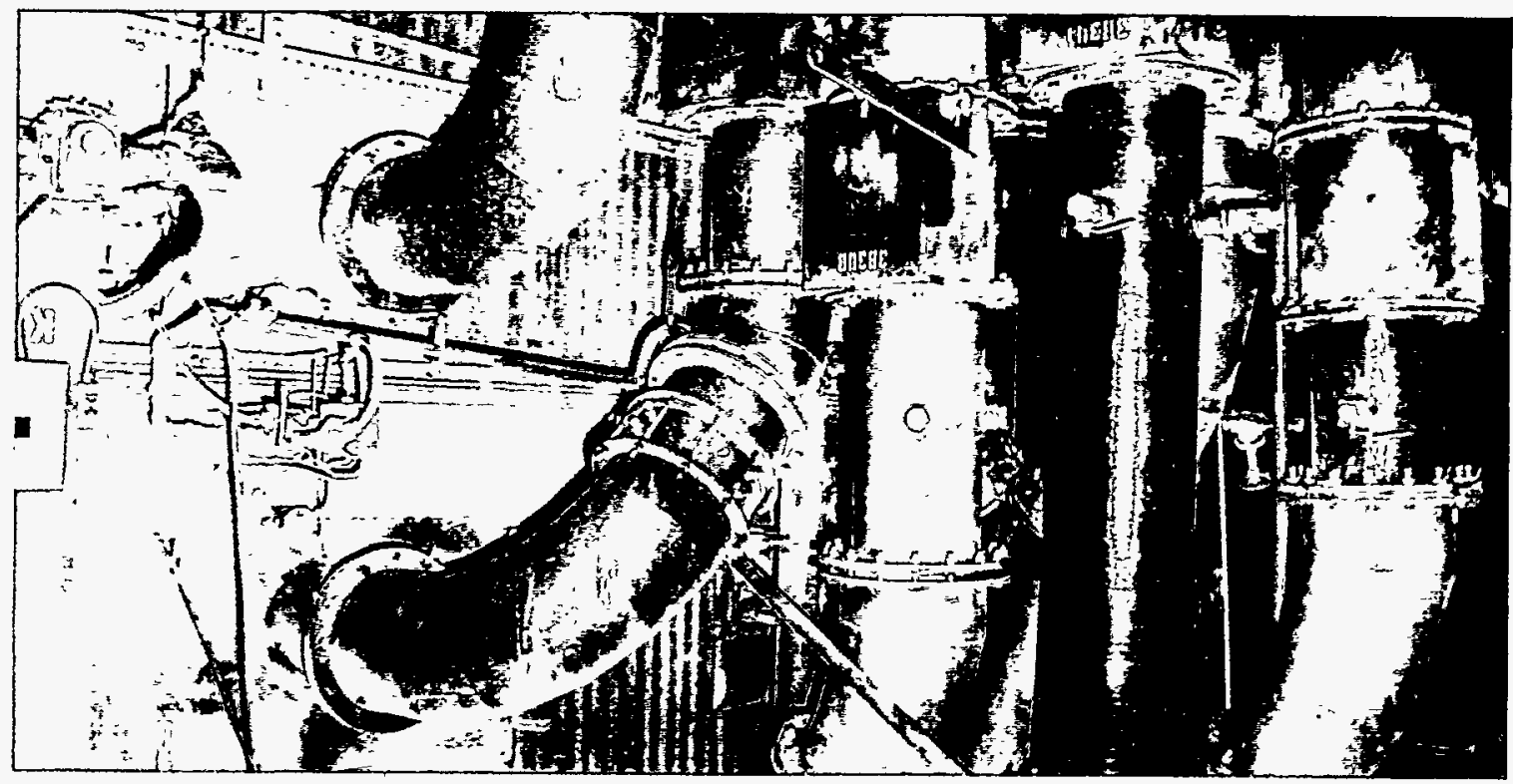




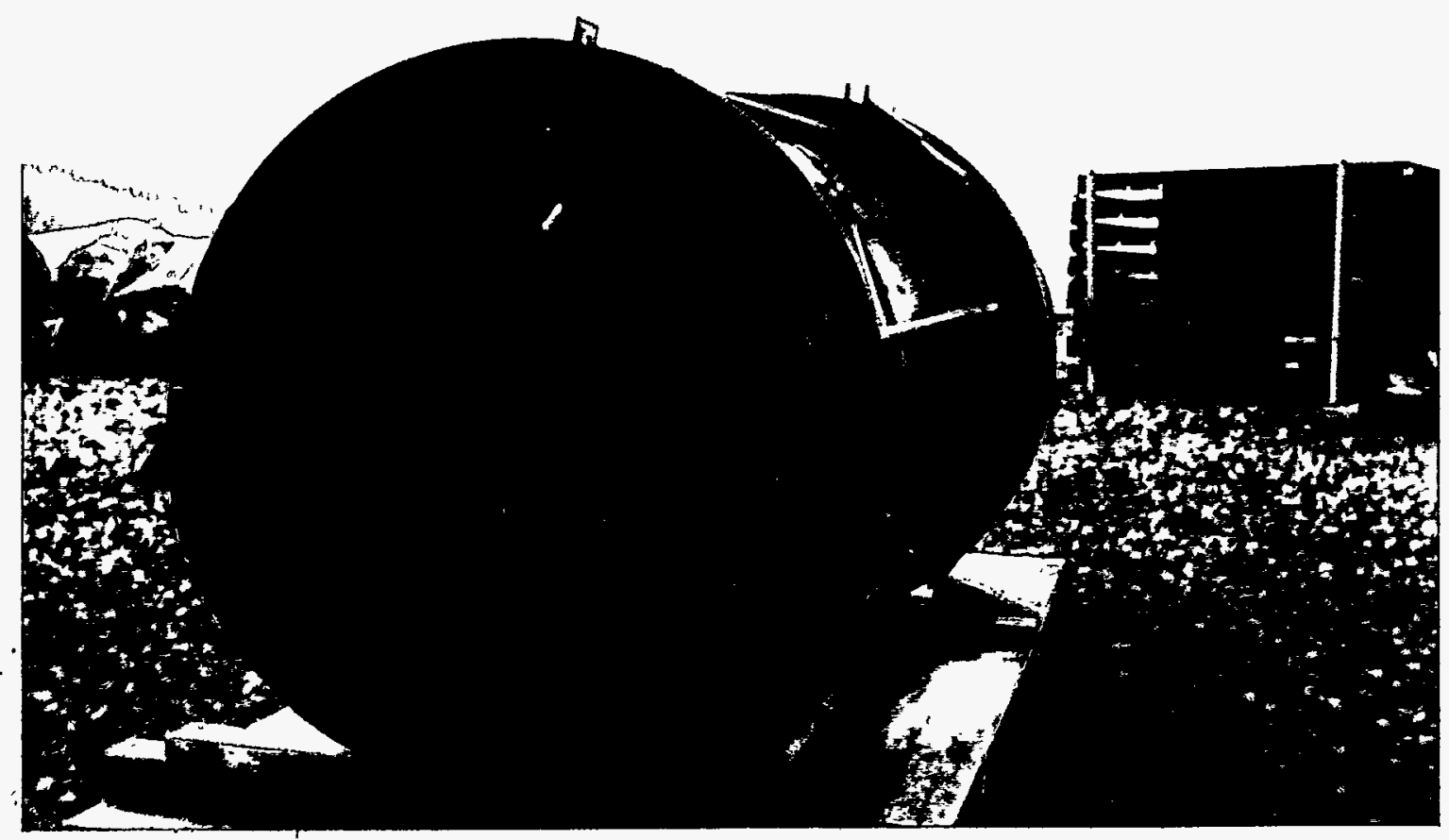

Figure 4-7 The burner portion of a LNCB ${ }^{\mathrm{TM}}$ burner lies in the laydown yard prior to installation. The impeller is not yet installed in the coal nozzle and the high-temperature alloy spin vanes are in the closed position.

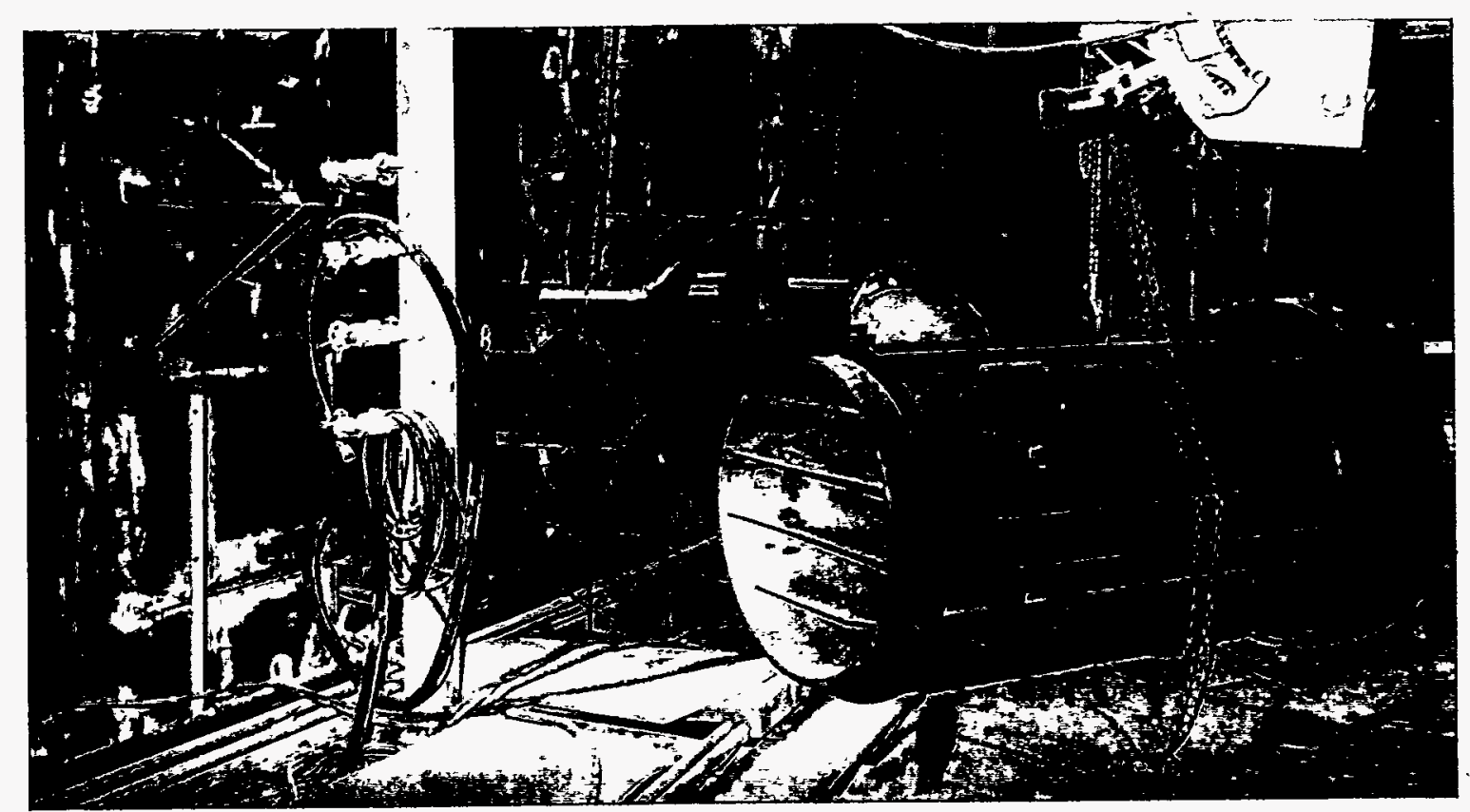

Figure 4-8 A louvered $\mathrm{NO}_{\mathrm{x}}$ port is rigged for installation above the burner. Both the burner and $\mathrm{NO}_{\mathrm{x}}$ port utilize existing furnace tube wall openings. 


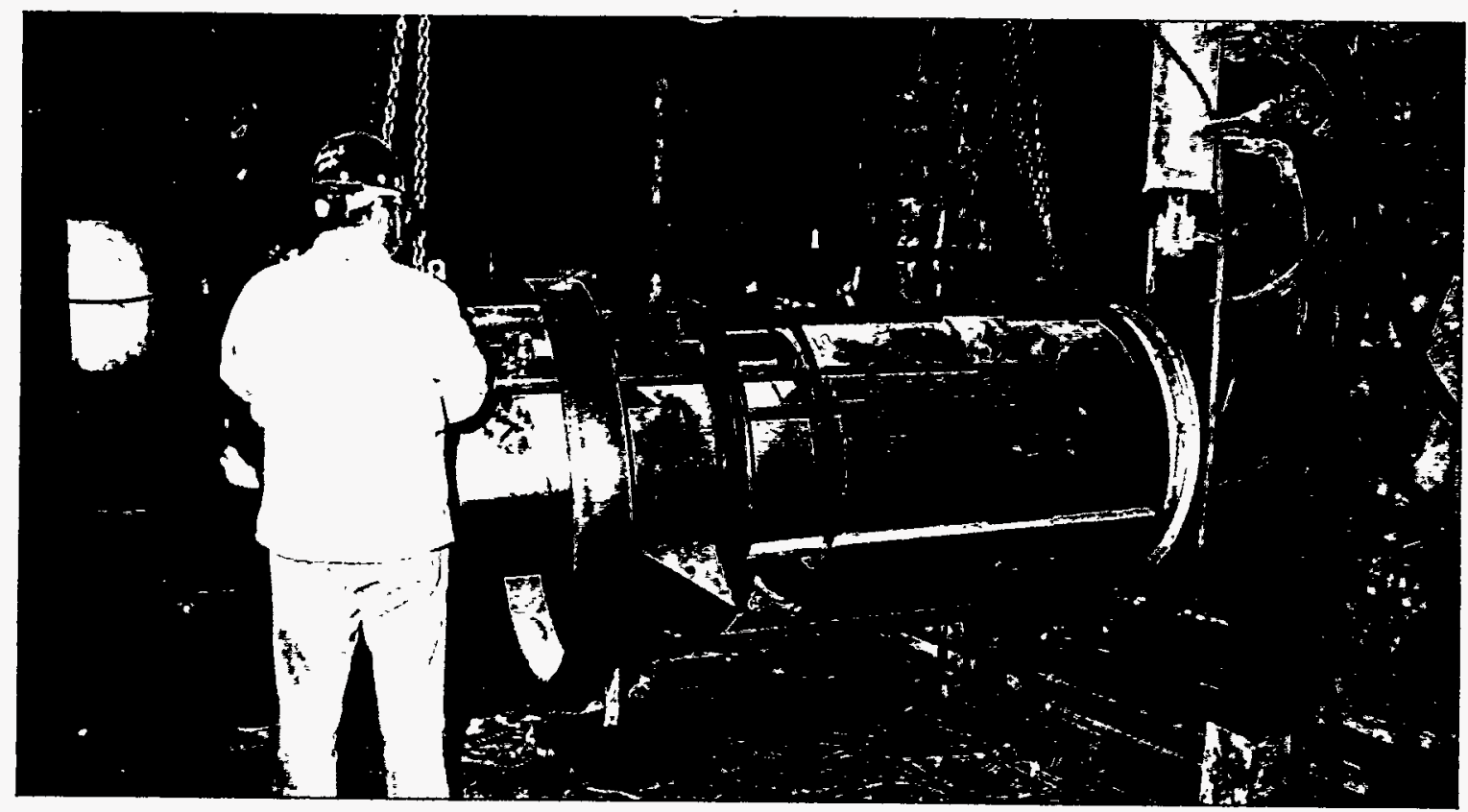

Figure 4-9 The burner portion of the $\mathrm{LNCB}^{\mathrm{TM}}$ burner is hoisted into place. The furnace end of the burner is constructed of high-temperature alloy steel. This burner now provides $220 \times 10^{6} \mathrm{Btu} / \mathrm{hr}$ of fuel input to the unit.

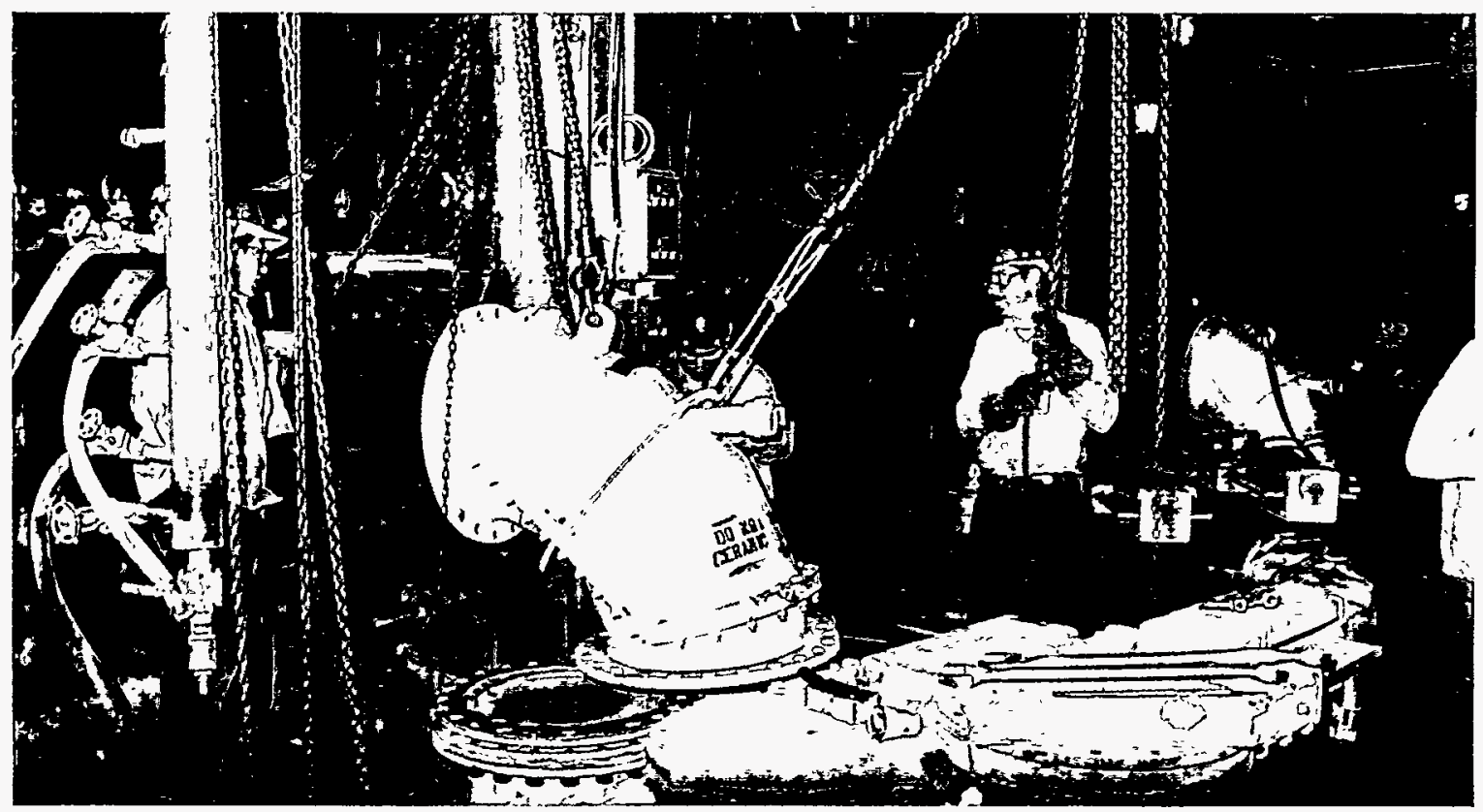

Figure 4-10 A ceramic-lined coal elbow is installed on the burner front. The ceramic lining resists the erosive effects of the pulverized coal. 


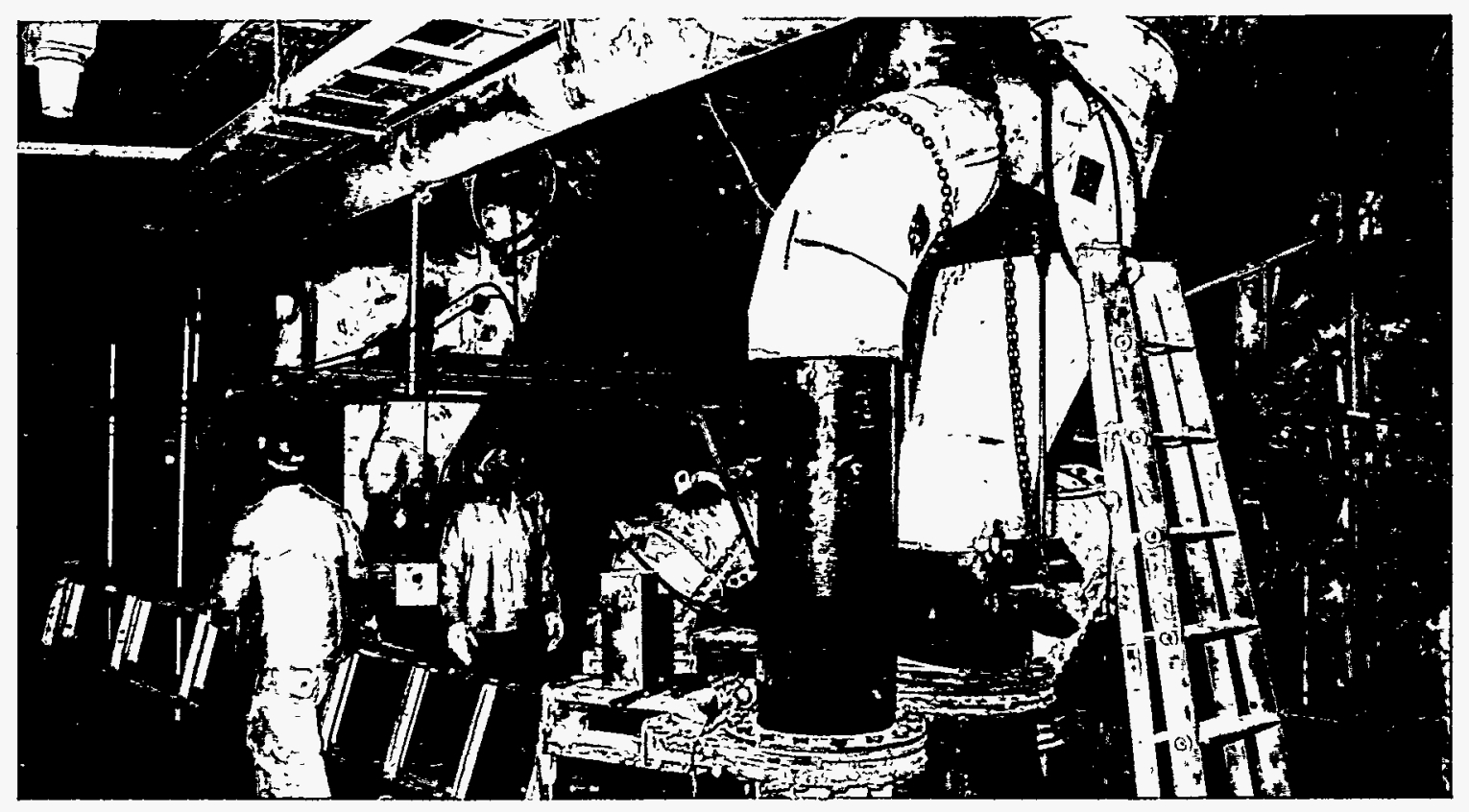

Figure 4-11 An installed ceramic-lined Y-pipe combines two of the original coal lines.

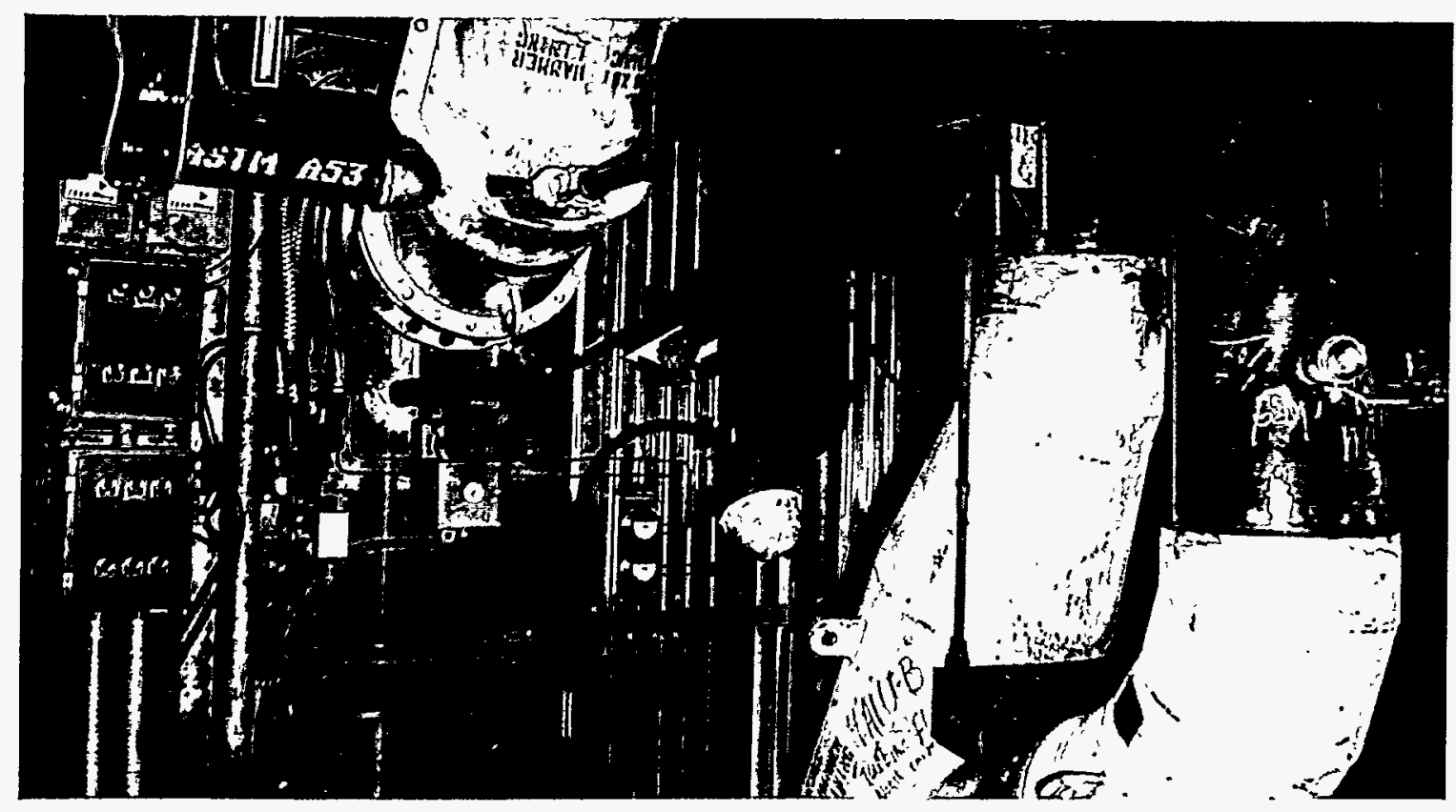

Figure 4-12 A completed LNCB $^{\mathrm{TM}}$ burner as viewed from the burner platform. The Y-pipe, which feeds one $\mathrm{LNCB}^{\mathrm{TM}}$ burner on the second row, is shown at the left in this photo. The $\mathrm{NO}_{\mathrm{x}}$ port is located just above the ceramic-lined coal elbow. 


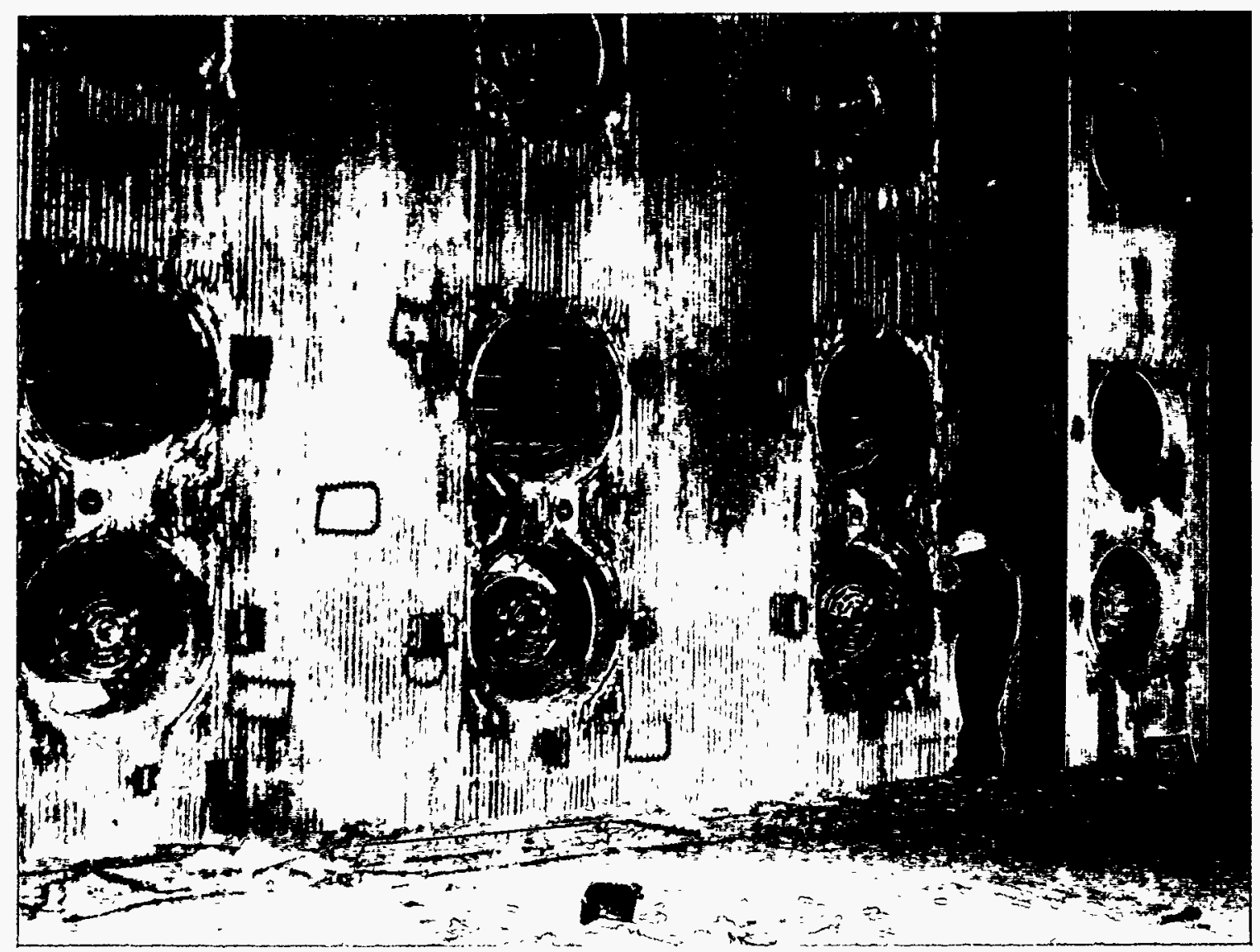

Figure 4-13 A wall of $\mathrm{LNCB}^{\mathrm{TM}}$ burners viewed from inside the furnace prior to inversion of every other lower level burner and $\mathrm{NO}_{\mathrm{x}}$ port. Each burner and $\mathrm{NO}_{\mathrm{x}}$ port function as a unit and constitute one Low$\mathrm{NO}_{\mathrm{x}}$ Cell $^{\mathrm{TM}}$ burner. 


\section{Section 5 \\ POST-RETROFIT TESTING}

\subsection{Parametric Testing Overview}

Parametric testing was conducted at J. M. Stuart Station \#4 (JMSS4) from May 11 to June 4, 1992, following completion of the lower row burner inversion (Figure 4-1). The purpose of this study was to evaluate the impact of $\mathrm{LNCB}^{\mathrm{TM}}$ burner equipment adjustments on $\mathrm{NO}_{\mathrm{x}}$ emissions and overall unit performance. In effect, the burners were fine tuned for optimum performance.

5.1.1 Test Parameters. The following parameters were varied to evaluate their affect on $\mathrm{LNCB}^{\mathrm{TM}}$ performance. The parametric testing are as follows:

- Burner spin vanes

- Burner throat stoichiometry

- Air port louver settings

- Unit load (mills in service)

- Position of coal impellers in nozzle

- Pulverizer fineness (primary air flow)

Testing results are described in this section.

5.1.2 Boiler Performance Characterization. Table 5-1 shows the $\mathrm{LNCB}^{\mathrm{TM}}$ burner test setups and resulting emissions data. The first three parametric tests - Tests 1,3 , and 5 - evaluated the effects of burner spin vanes at $50^{\circ}, 40^{\circ}$, and $60^{\circ}$ open, respectively. Subsequent tests held all spin vanes at $60^{\circ}$ open.

The objective of Tests 8 through 12 was to investigate the effects of gradually closing the sliding air dampers of the upper level burners and effectively reduced burner throat stoichiometry. Burner throat stoichiometry testing continued with Tests 13 through 16. Sliding air dampers on the six inverted burners were gradually closed.

Tests 17 through 21 investigated the effects of $\mathrm{NO}_{\mathrm{x}}$ port louver damper adjustments which were varied in $5^{\circ}$ increments from $0^{\circ}$ (horizontal) to $15^{\circ}$ (above horizontal).

It should be noted that prior to Test 9 it was decided to set all six inverted $\mathrm{NO}_{\mathrm{x}}$ port louvers (i.e., $\mathrm{LNCB}^{\mathrm{TM}}$ burners with $\mathrm{NO}_{\mathrm{x}}$ ports on the bottom) to a $-20^{\circ}$ position. This directed secondary air downward toward the hopper to minimize $\mathrm{CO}$ and $\mathrm{H}_{2} \mathrm{~S}$ concentrations in this region. Also, prior to Test 17, it was decided to place the sliding air dampers of the six "normal" (i.e., un-inverted) lower row burners to the same final settings as those of the others. Test 22 was integrated into Test 21 as the optimum $\mathrm{NO}_{\mathrm{x}}$ port louver position. 
Table 5-1

PARAMETRIC TESTING RESULTS

\begin{tabular}{|c|c|c|c|c|c|c|c|c|c|c|c|c|c|}
\hline \multirow{3}{*}{ 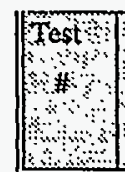 } & \multirow{3}{*}{ (3) Comments } & \multirow{3}{*}{ made } & \multirow{3}{*}{ 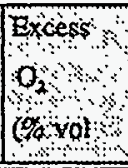 } & \multicolumn{3}{|c|}{ Bürer Spin Yanes (opert) } & \multicolumn{3}{|c|}{ Na Pord Louvers } & \multirow{3}{*}{ Wodtox } & \multicolumn{3}{|c|}{ Test'Data Colfection by B \&W } \\
\hline & & & & \multicolumn{2}{|c|}{ Lowercels } & \multirow{2}{*}{$\begin{array}{l}\text { uppet: } \\
\text { Ajos: }\end{array}$} & \multicolumn{2}{|c|}{ Lower Cels : } & \multirow{2}{*}{ ofipger } & & \multirow{2}{*}{$\begin{array}{l}\text { Asti } \\
\text { Anilyos }\end{array}$} & \multirow{2}{*}{80} & \multirow{2}{*}{$\begin{array}{c}\mathrm{NO} \\
\mathrm{ppan} \\
\mathrm{pan}\end{array}$} \\
\hline & & & & Notriall & matrid & & loyeded & Noithal & & & & & \\
\hline 1 & \begin{tabular}{|l|} 
Vary Spin Vanes - 50 \\
\end{tabular} & 550 & dingl.50 & 50 & 50 & 50 & 0 & $\mathbf{0}$ & 0 & Presth:trop & $2.24 / \mathrm{NA}$ & N.A. & N.A. \\
\hline 3 & Vary Spin Vanes - 60 & 604 & 3.74 & 60 & 60 & 60 & $\mathbf{0}$ & $\mathbf{0}$ & 0 & 2.14 & $2.39 / 2.48$ & N.A. & 441 \\
\hline 5 & Vary Spin Vanes - 40 & 599 & 3.80 & 40 & 40 & 40 & 0 & $\mathbf{0}$ & 0 & 2.40 & $2.66 / 2.76$ & 48 & 453 \\
\hline 7 & Optimum Spin Vane Pos. - 60 & 600 & 3.75 & 60 & 60 & 60 & 0 & 0 & 0 & 2.06 & $3.31 / \mathrm{NA}$ & 20 & 486 \\
\hline 8 & Vary Upper Bumer Stoich. & 604 & 3.84 & 60 & 60 & 60 & $\mathbf{0}$ & 0 & 0 & 2.12 & $4.70 / 2.49$ & 34 & 452 \\
\hline 9 & Vary Upper Bumer Stoich. & 603 & 3.53 & 60 & 60 & 60 & -20 & 0 & $\mathbf{0}$ & 2.26 & $7.21 / \mathrm{NA}$ & 23 & 453 \\
\hline 10 & Vary Upper Burner Stoich. & 601 & 3.45 & 60 & 60 & 60 & -20 & 0 & 0 & 2.88 & $6.02 / 1.53$ & 23 & 442 \\
\hline 11 & Vary Upper Bumer Stoich. & 602 & 3.45 & 60 & 60 & 60 & -20 & 0 & 0 & 3.18 & $6.52 / 0.61$ & 21 & 453 \\
\hline 12 & Optimum Upper Burmer Stoich & 604 & 3.32 & 60 & 60 & 60 & -20 & 0 & $\mathbf{0}$ & 2.93 & $3.06 / 0.42$ & 22 & 447 \\
\hline 13 & Vary Inverted Bumer Stoich. & 605 & 3.17 & 60 & 60 & 60 & -20 & 0 & 0 & 2.63 & $2.92 / 0.74$ & 25 & 433 \\
\hline 14 & Vary Inverted Bumer Stoich. & 603 & 3.41 & 60 & 60 & 60 & -20 & $\overline{0}$ & $\mathbf{0}$ & 2.96 & N.A. & 22 & 406 \\
\hline 15 & Vary Inverted Burner Stoich. & 603 & 3.47 & 60 & 60 & 60 & -20 & 0 & 0 & 3.12 & N.A. & 19 & 404 \\
\hline 16 & Optimum Inv. Bumer Stoich. & 603 & 3.65 & 60 & 60 & 60 & -20 & 0 & $\mathbf{0}$ & 3.00 & $1.52 / 1.34$ & 34 & 432 \\
\hline 17 & Vary $\mathrm{NO}_{x}$ Port Louvers 0 & 603 & 3.51 & 60 & 60 & 60 & -20 & 0 & 0 & 3.18 & NA/1.84 & 47 & 422 \\
\hline 18 & Vary $\mathrm{NO}_{x}$ Port Louvers +5 & 603 & 3.62 & 60 & 60 & 60 & -20 & +5 & +5 & 3.17 & N.A. & 21 & 400 \\
\hline 19 & Vary $\mathrm{NO}_{\mathrm{x}}$ Port Louvers +10 & 603 & 3.85 & 60 & 60 & 60 & -20 & +10 & +10 & 3.64 & N.A. & 38 & 388 \\
\hline 20 & Vary $\mathrm{NO}_{\mathrm{x}}$ Port Louvers +15 & 603 & 3.80 & 60 & 60 & 60 & -20 & +15 & +15 & 4.60 & $1.91 / 0.54$ & 54 & 383 \\
\hline 21 & Optimum Louver Position +15 & 603 & 3.71 & 60 & 60 & 60 & -20 & +15 & +15 & 4.16 & $1.58 / 0.45$ & 58 & 375 \\
\hline 23 & Mill Out of Service 1/2 Load & 350 & 7.15 & 60 & 60 & 60 & -20 & +15 & +15 & 2.43 & $0.92 / 5.73$ & 20 & 236 \\
\hline 24 & Mill Out of Service 3/4 Load & 458 & 5.36 & 60 & 60 & 60 & -20 & +15 & +15 & 2.77 & $2.61 / 3.33$ & 21 & 294 \\
\hline 25 & Mill Out of Service Full Load & 600 & 4.10 & 60 & 60 & 60 & -20 & +15 & +15 & 4.75 & $1.51 / 3.13$ & 28 & 353 \\
\hline 26 & Vary NOx Port Louvers +20 & 602 & 3.90 & 60 & 60 & 60 & -20 & +20 & +20 & 4.28 & $3.09 / 1.62$ & 50 & 390 \\
\hline 27 & Impellers Retracted $14^{\prime \prime}$ & 603 & 3.27 & 60 & 60 & 60 & -20 & +20 & +20 & 3.81 & $3.85 / 0.76$ & 74 & 405 \\
\hline 28 & Vary Bumer Throat Stoich. & 601 & 3.58 & 60 & 60 & 60 & -20 & +20 & +20 & 4.42 & $2.92 / 1.11$ & 41 & 385 \\
\hline 29 & Min. Burner Throat Stoich. & 601 & 3.66 & 60 & 60 & 60 & -20 & +20 & +20 & 6.79 & N.A. & 38 & 356 \\
\hline 30 & Mill Fineness (High PA Flow) & 602 & 3.68 & 60 & 60 & 60 & -20 & +20 & +20 & 4.26 & $5.66 / 3.71$ & 25 & 377 \\
\hline
\end{tabular}

Note - Tests 2, 4, 6 combised in Test 27. Test 22 combined in Test 21. Coolibg flow for Out-ot-Service NOx Ports is $25{ }^{\circ}$ Wg ecross the air now monitors. 
Test 23 was performed at approximately half-boiler load with Mills A and F out of service. Test 24 was run at three-quarter load and Test 25 at full load, both with A mill out of service. Test 26 was at full load with all mills in service and the $\mathrm{NO}_{\mathrm{x}}$ port louvers set to direct the air flow at a $+20^{\circ}$ divergent from each flame.

Test 27 was run at the same burner settings as those for Test 26 but with all 24 coal impellers retracted 14 inches inside the burner nozzles. Retracting the coal nozzles was expected to lengthen the flame size and potentially reduce the $\mathrm{NO}_{\mathrm{x}}$ formation. In actuality, however, $\mathrm{NO}_{\mathrm{x}}$ formation increased. Therefore, the impellers were returned to their normal operating position, i.e., 1 inch from the end of the nozzle.

For Tests 28 and 29, burner sliding air dampers were adjusted to restrict air flow to a point where the flow indicators registered differentials of 1.5 inches and 1.0 inch W.G., respectively. Test 29 showed the lowest $\mathrm{NO}_{\mathrm{x}}$ emission, but at the expense of substantial burner pressure drop which increases fan power requirements.

Test 30 was performed with the same sliding air damper setting used for Test 28 , but under relatively poor coal fineness conditions which were simulated by increasing primary air flow through the pulverizers. The additional air flow carries coarser coal particles into the burner line. This test simulated operation with coal pulverizers in need of maintenance. Based on results of the parametric testing, Test 28 settings were selected for optimization testing and $\mathrm{LNCB}^{\mathrm{TM}}$ burner operation.

5.1.3 Continuous Emissions Monitoring Results. To quantify $\mathrm{NO}_{\mathrm{x}}$ emission levels at the economizer outlet, a continuous emissions monitoring (CEM) system was concurrently used with the temporary gas analysis system. Each of two economizer ducts was fitted with ten sampling ports across its top width and a two-point sampling probe which sampled flue gas at depths of 22 and 112 inches was used to traverse all ports to establish a side-to-side profile for each gas species.

Three ports representing 12 points in each duct were typically used as indicators during changes in boiler operation and/or burner settings. When an optimal combination of parameters was established, flue gas samples were extracted from all ports representing a total of 40 points. Every other sampling port, representing 20 points, was used when total $\mathrm{O}_{2}$ or mills out-of-service was varied.

Test 3 was an exception to the test procedure discussed above. All ports were used, but gas samples were withdrawn from four equally spaced depths giving a total of 80 sample points. This approach was included in part to determine the capabilities of the CEM sampling system and traverse method.

Raw data from each test port were averaged and corrected for drift and moisture content with the resulting values used to determine the average emission level at each economizer outlet.

The following observations can be made from the results of the parametric testing in Table 5-1:

- At a full load of $600 \mathrm{MWe}$, the lowest $\mathrm{NO}_{\mathrm{x}}$ emission rate was measured from Test 25, when Mill A was out of service and excess $\mathrm{O}_{2}$ was $4.10 \%$. By operating JMSS4 with five mills instead of six at full load, $\mathrm{NO}_{\mathrm{x}}$ emissions were reduced to an average of $353 \mathrm{ppm}\left(0.46 \mathrm{lbm} / 10^{6} \mathrm{Btu}\right)$.

- At reduced loads, the lowest $\mathrm{NO}_{\mathrm{x}}$ emission rate was measured from Test 23, during which Mill $\mathrm{A}$ was out of service and excess $\mathrm{O}_{2}$ was $7.15 \%$ at a boiler load of $350 \mathrm{MWe}$. $\mathrm{NO}_{\mathrm{x}}$ emissions were reduced to an average of $236 \mathrm{ppm}\left(0.31 \mathrm{lbm} / 10^{6} \mathrm{Btu}\right)$. 
- In general, operation with mills out-of-service and reduced load led to the lowest average of $\mathrm{NO}_{\mathrm{x}}$ emissions, ranging from 236 to $294 \mathrm{ppm}\left(0.31\right.$ to $\left.0.39 \mathrm{lbm} / 10^{6} \mathrm{Btu}\right)$.

- The lowest $\mathrm{NO}_{\mathrm{x}}$ measured with all mills in service at full load was $356 \mathrm{ppm}\left(0.47 \mathrm{lbm} / 10^{6} \mathrm{Btu}\right)$ recorded during Test 29. This test also caused an increase in burner air-side pressure drop that was not acceptable to DP\&L.

- Average $\mathrm{CO}$ emissions throughout all parametric tests ranged from 19 to $74 \mathrm{ppm}$, corrected to $3 \%$ $\mathrm{O}_{2}$. For the majority of the tests, however, $\mathrm{CO}$ was below $30 \mathrm{ppm}$. Higher $\mathrm{CO}$ concentrations were typically found in the west economizer duct towards the center of the furnace, where low $\mathrm{O}_{2}$ levels were generally present.

- Average $\mathrm{NO}_{\mathrm{x}}$ emission rates decreased with reducing excess air.

Parametric testing successfully determined the optimum burner settings for 1) minimizing $\mathrm{NO}_{\mathrm{x}}$ formation and 2) defining the operating characteristics of JMSS4. The final burner settings chosen for optimization testing phase were as follows:

- Burner spin vanes $-60^{\circ}$ from fully closed

- Burner throat stoichiometry - 1.5 inches W.G. on the air flow monitor, which is equivalent to a 0.58 stoichiometric air flow

- $\mathrm{NO}_{\mathrm{x}}$ port louver settings $-20^{\circ}$ divergent from the flame (the inverted cells $-20^{\circ}$, all others $+20^{\circ}$ )

- Coal impellers - in standard position (not retracted)

- Primary air flow - normal level

\subsection{Optimization Testing}

Optimized performance testing was conducted during the period of June 15 through July 1, 1992, in

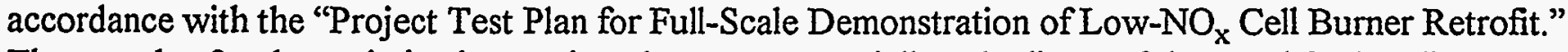
The test plan for the optimization testing phase was essentially a duplicate of that used for baseline testing.

5.2.1 Test Conditions. Table 5-2 provides a chronological listing of test conditions investigated at JMSS4 during optimization testing. An additional test condition (8R1), not part of the baseline testing, was incorporated into the test matrix. It was included because of evidence that $\mathrm{NO}_{\mathrm{x}}$ could be further reduced with an upper mill group out-of-service. DP\&L indicated that similar results could be obtained by bias firing one of the upper mill groups. Therefore, Test $8 \mathrm{R} 1$ utilized a biased firing strategy to simulate a mill out-of-service condition, even though all mills were in service.

As previously mentioned, burner sliding air damper settings were determined from Test 28 of the parametric testing (Table 5-1). Assuming a uniform coal and air distribution, these settings yielded an average stoichiometry of 0.58 at the burners.

The optimization testing was conducted at three different unit loads.

- Full load (601 - 606 MWe)

- Intermediate load (456 - $462 \mathrm{MWe})$

- Low load (349 - 350 MWe) 
Table 5-2

CHRONOLOGICAL LISTING OF OPTIMIZED TESTS

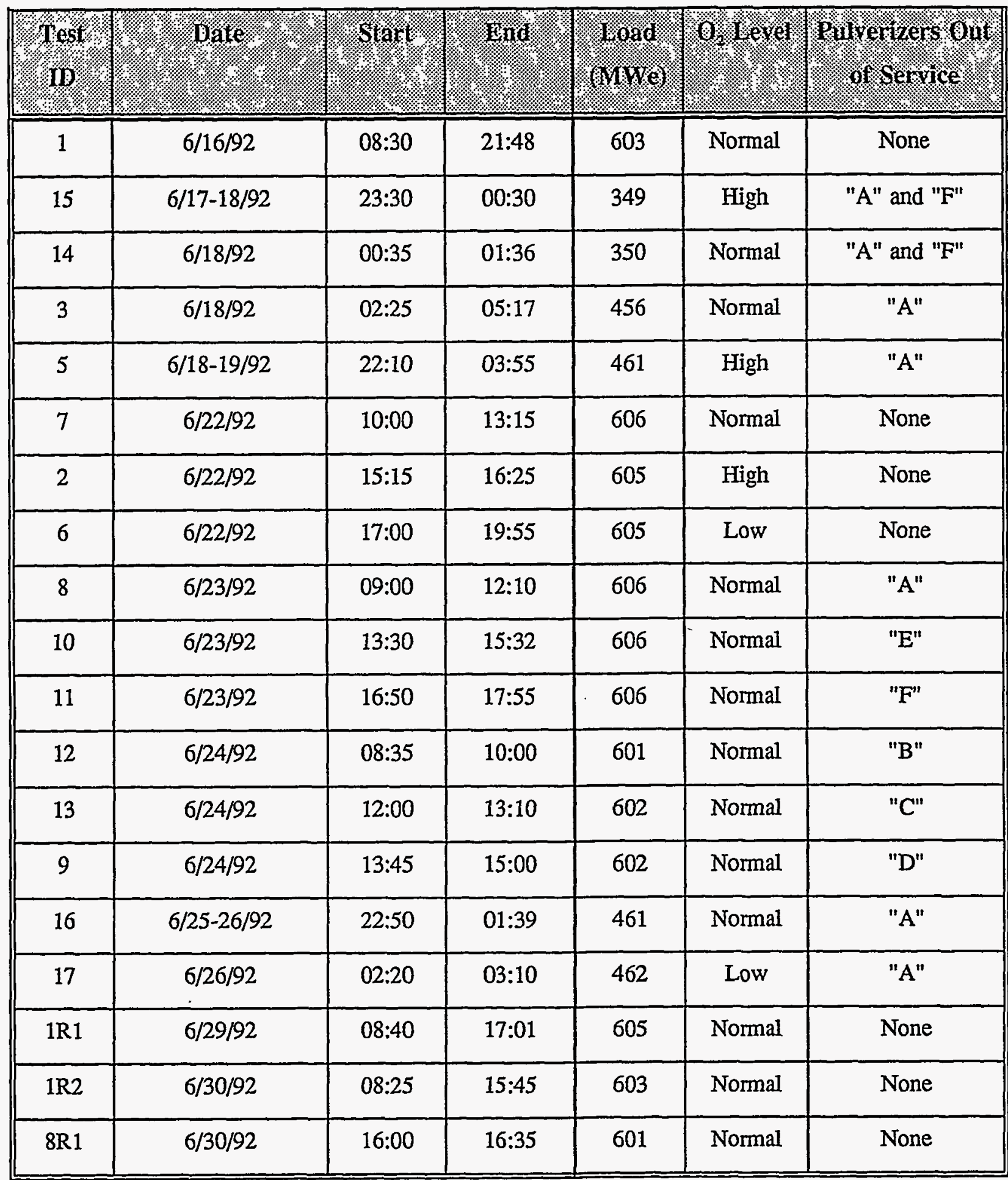


The break-down of the optimization tests was as follows:

- Thirteen full load tests were performed at an average load of $604 \mathrm{MWe}$.

- Seven tests were conducted with all pulverizers in service.

Four tests were repeats for comparison purposes with normal operating conditions.

One with high excess air.

One with low excess air.

One with mill biasing (Test 8R1).

- Six tests were conducted with one of the six mills out-of-service, and this mill was different for each test. All tests were conducted at normal excess air levels.

- Four intermediate load tests were performed at an average load of $460 \mathrm{MWe}(76 \%$ of full load) with Mill A out-of-service.

- Two with normal excess air levels.

- One with high excess air.

- One with low excess air.

- Two low load tests were performed at an average load of $350 \mathrm{MWe}$ ( $58 \%$ of full load) with Mills $\mathrm{A}$ and $\mathrm{F}$ out of service.

- One with high excess air.

- One with normal excess air.

5.2.2 Evaluation Methodology. In order to evaluate the results of optimization testing, an understanding of the positive and negative performance parameters was needed. With the goal of at least $50 \%$ reduction in $\mathrm{NO}_{\mathrm{x}}$ emissions, the following factors must also be considered when evaluating the results of the optimization testing.

- A substantial increase in the $\mathrm{CO}$ and particulate emissions would be detrimental to the success of $\mathrm{NO}_{\mathrm{x}}$ reduction.

- A reduction in the unit's operating range would be detrimental.

- A reduction in the stoichiometry of the burner could exacerbate corrosion and furnace wall wastage.

- Increased heating transfer surface fouling that would be detrimental by increasing fan power consumption, reduce final steam temperatures, and decrease overall unit efficiency.

- A significant change in FEGT could have detrimental effects on heat transfer surface and boiler performance. For example, an increase in FEGT could cause an increase in the metallurgical requirements for $\mathrm{SH}$ and $\mathrm{RH}$ surfaces. A decrease in FEGT could affect the steam temperature control range of $\mathrm{RH}$.

- An increase in the UBC loss would directly reduce the unit's overall energy efficiency.

5.2.3 Environmental Effects of Low-NO ${ }_{x}$ Cell ${ }^{\mathrm{TnI}}$ Burner. All operating parameters investigated during baseline testing were tested again during the optimization testing. The operating results obtained from these two tests were carefully compared. Changes were tabulated and are presented in the following sections.

The environmental impact of $\mathrm{LNCB}^{\mathrm{TM}}$ burners was the prime concern of this project. The $\mathrm{NO}_{\mathrm{x}}$ emission rate must be significantly reduced without adverse effects on other boiler emissions. For additional information, refer to the Optimized Testing Interim Report. 
5.2.3.1 $\mathrm{NO}_{\mathrm{x}}$ Emissions. The $\mathrm{NO}_{\mathrm{x}}$ emission rate was determined by both Acurex Environmental and Babcock \& Wilcox (B\&W) at the economizer outlet. This sampling location was a change for B\&W who conducted $\mathrm{NO}_{\mathrm{x}}$ emission measurements at the secondary airheater outlet during baseline testing. The reason for this change was to make $\mathrm{NO}_{\mathrm{x}}$ measurements and data comparison more consistent. However, like baseline testing, $B \& W$ measurements were obtained from composite gas samples drawn from the sampling grid, while Acurex collected their data from a point-by-point sampling system.

Results of the $\mathrm{NO}_{x}$ emissions from both companies showed very good agreement. Figures 5-1 through 54 compare $\mathrm{NO}_{\mathrm{x}}$ emissions versus unit output for both $\mathrm{B} \& \mathrm{~W}$ and Acurex data. Figures 5-5 through 5-8 summarize $\mathrm{NO}_{x}$ emissions versus excess air for each company. Figure 5-9 shows the percentage reduction from the baseline values for each test.

The average $\mathrm{NO}_{\mathrm{x}}$ emission rate for full load tests with all mills in service was $0.517 \mathrm{lbm} / 10^{6}$ for $\mathrm{B} \& W$ 's data and $0.551 \mathrm{lbm} / 10^{6}$ for Acurex's data. Compared to baseline results, these emission rates represented a NO${ }_{x}$ reduction of $55.5 \%$ and $53.0 \%$, respectively.

Average $\mathrm{NO}_{\mathrm{x}}$ emission rates for full load with one mill out of service were $0.496 \mathrm{lbm} / 10^{6}$ and $0.505 \mathrm{lbm} /$ $10^{6}$ from B\&W's and Acurex's data, respectively, which respectively represent a $53.3 \%$ and $54.5 \% \mathrm{NO}_{\mathrm{x}}$ reductions from baseline conditions.

Average $\mathrm{NO}_{\mathrm{x}}$ emission rates for intermediate load were $0.418 \mathrm{lbm} / 10^{6}$ from $\mathrm{B} \& W$ 's data and $0.418 \mathrm{lbm} /$ $10^{6}$ from Acurex's. Relative to baseline conditions, this corresponds to a $54.7 \%$ to a $52.5 \%$ reduction, respectively, .

The average $\mathrm{NO}_{\mathrm{x}}$ emission rates for the low load condition were $0.372 \mathrm{lbm} / 10^{6}$ from $\mathrm{B} \& W$ 's data and $0.370 \mathrm{lbm} / 10^{6}$ from Acurex's data. B\&W's data indicated a $46.9 \% \mathrm{NO}_{\mathrm{X}}$ reduction from the baseline tests; Acurex's data yielded a $47.9 \%$ reduction from baseline.

6.2.3.2 CO Emissions. $\mathrm{CO}$ emissions rates were determined by both $\mathrm{B} \& \mathrm{~W}$ and Acurex at the economizer outlet, identical to the baseline sampling location. As mentioned previously, $B \& W$ measurements were made on the composite samples collected from the sampling grid. On the other hand, Acurex measurements were obtained from a point-by-point sampling system. Figures 5-10 through 5-13 compare CO emissions measured by both B\&W and Acurex versus unit output, and Figures 5-14 through 5-17 show $\mathrm{CO}$ emissions versus excess air. The percentages of the change in $\mathrm{CO}$ from the baseline are shown Figure $5-18$.

Average $\mathrm{CO}$ emission rates, corrected to $3 \% \mathrm{O}_{2}$, for full load tests with all mills in service were $55 \mathrm{ppm}$ and $28 \mathrm{ppm}$ based on B\&W and Acurex data, respectively. Compared to baseline results, these emission rates correspondingly represented a $121.5 \%$ increase and a $76.8 \%$ decrease.

CO emission rates for full load tests with one mill out of service were $38 \mathrm{ppm}$ and $20 \mathrm{ppm}$ based on $\mathrm{B} \& \mathrm{~W}$ and Acurex data, respectively. Compared to baseline, these results correspondingly represented a $19.6 \%$ increase and $73.6 \%$ decrease for $B \& W$ and Acurex test results.

CO emission rates for low load tests averaged $27 \mathrm{ppm}$ and $5 \mathrm{ppm}$, corrected to $3 \% \mathrm{O}_{2}$, for $\mathrm{B} \& \mathrm{~W}$ and Acurex tests, respectively. Compared to baseline test results for this load, B\&W data showed a $6.0 \%$ increase and Acurex data showed a $96.1 \%$ decrease in $\mathrm{CO}$ emission rates. 


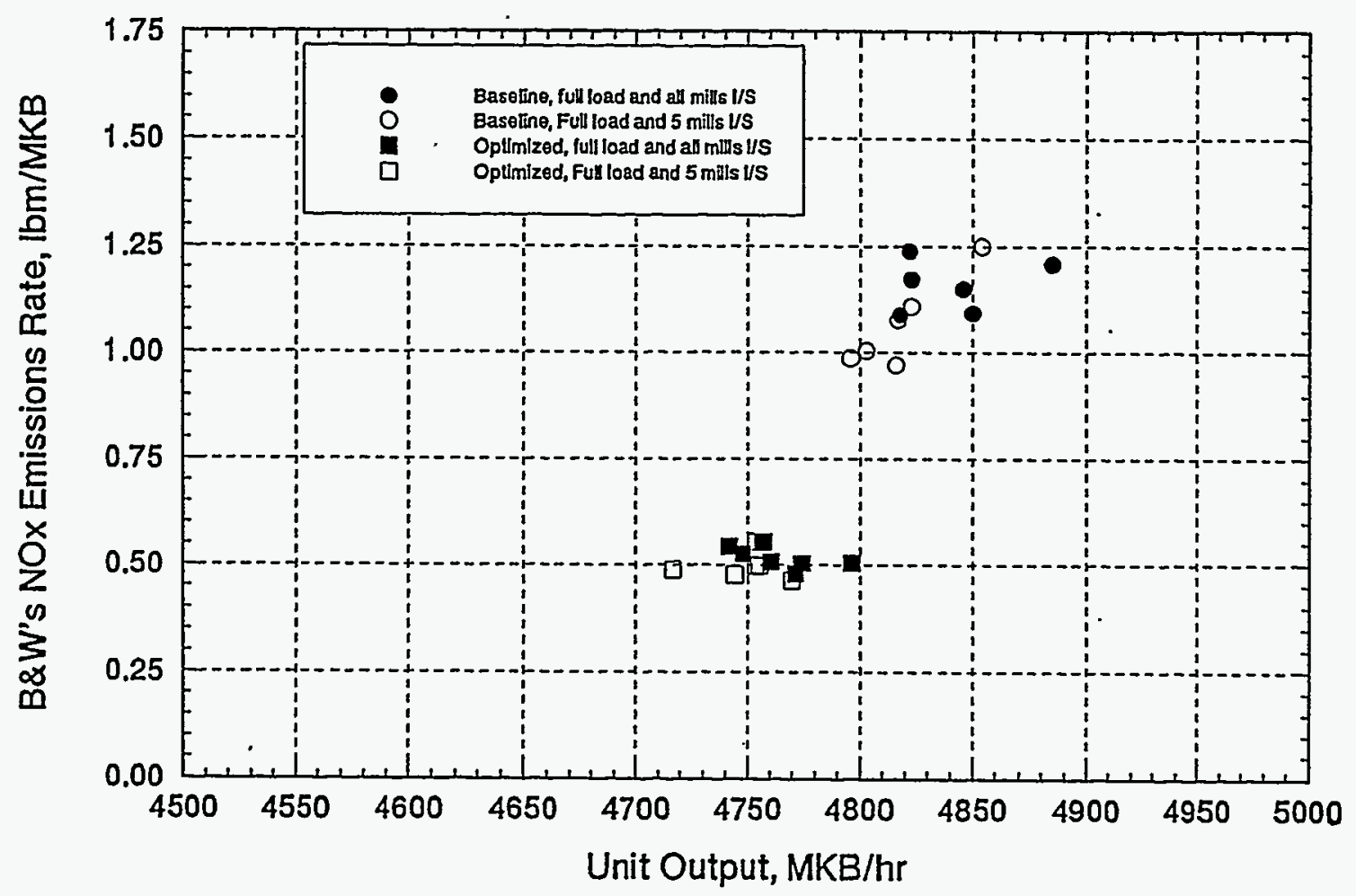

Figure 5-1 $\mathrm{NO}_{\mathrm{x}}$ emissions versus unit output at full load - $\mathrm{B} \& \mathrm{~W}$ data

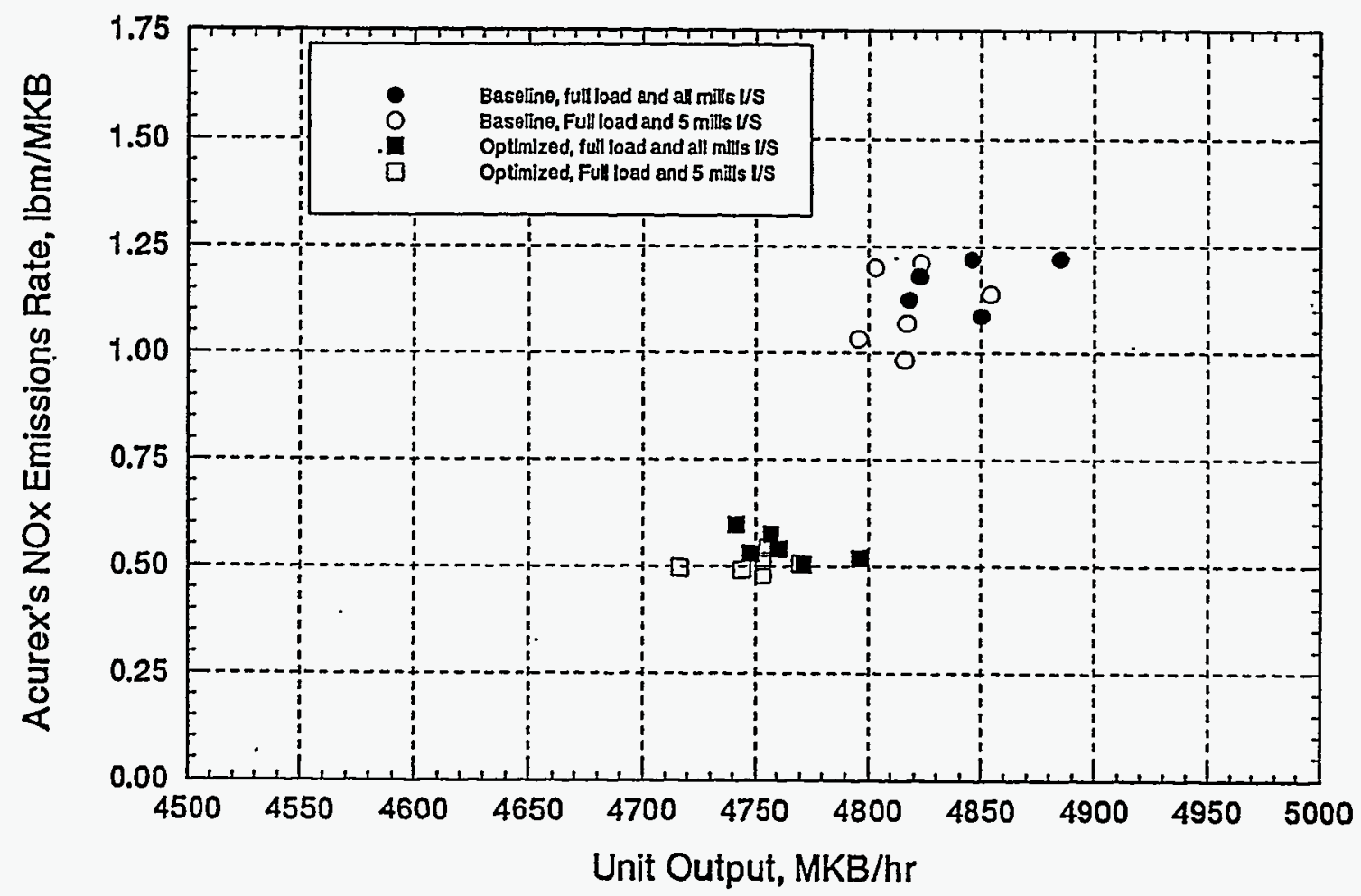

Figure 5-2 $\mathrm{NO}_{\mathrm{x}}$ emissions versus unit output at full load - Acurex data 


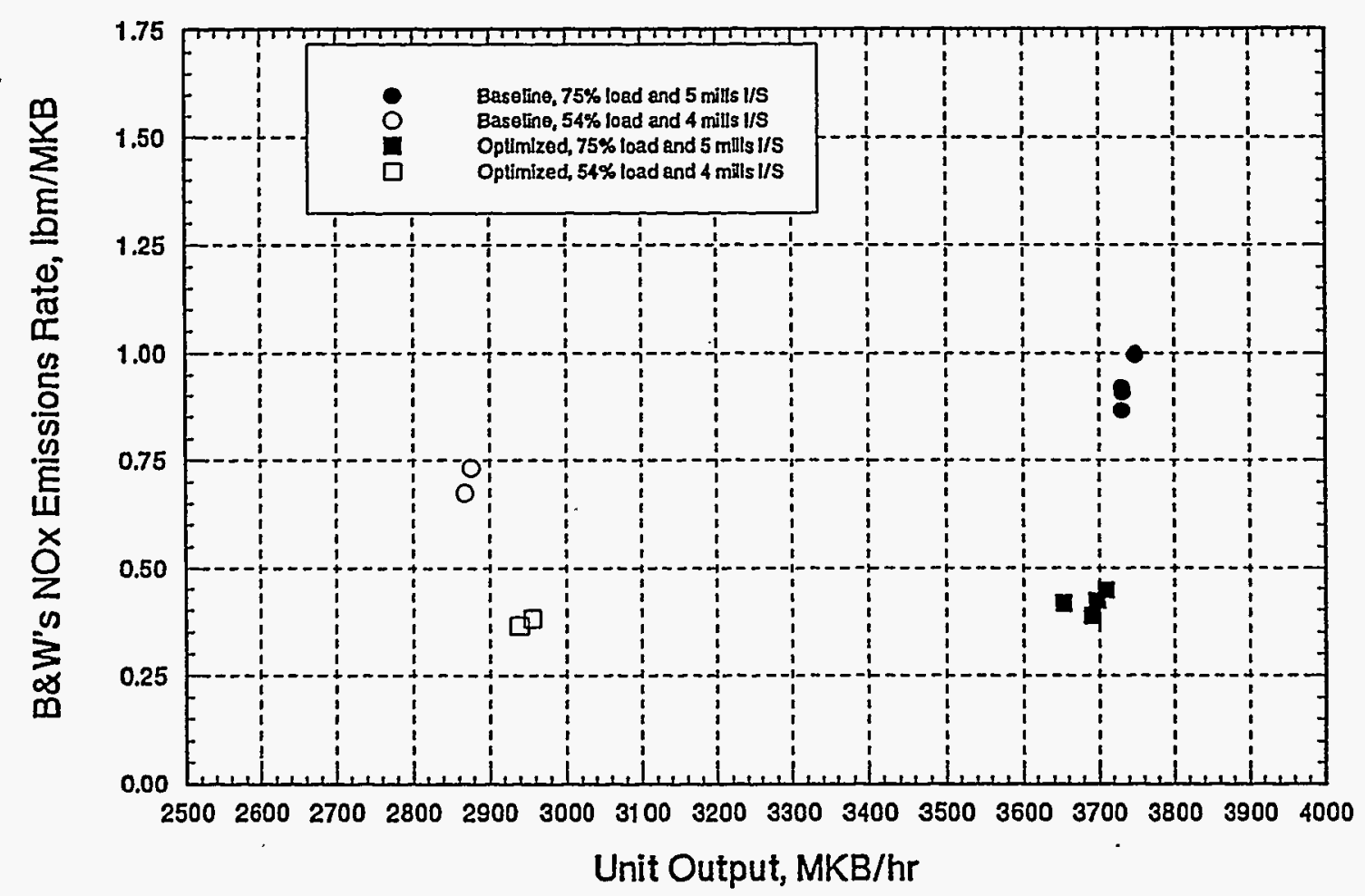

Figure 5-3 $\mathrm{NO}_{\mathrm{x}}$ emissions versus unit output at intermediate and low load - B\&W data

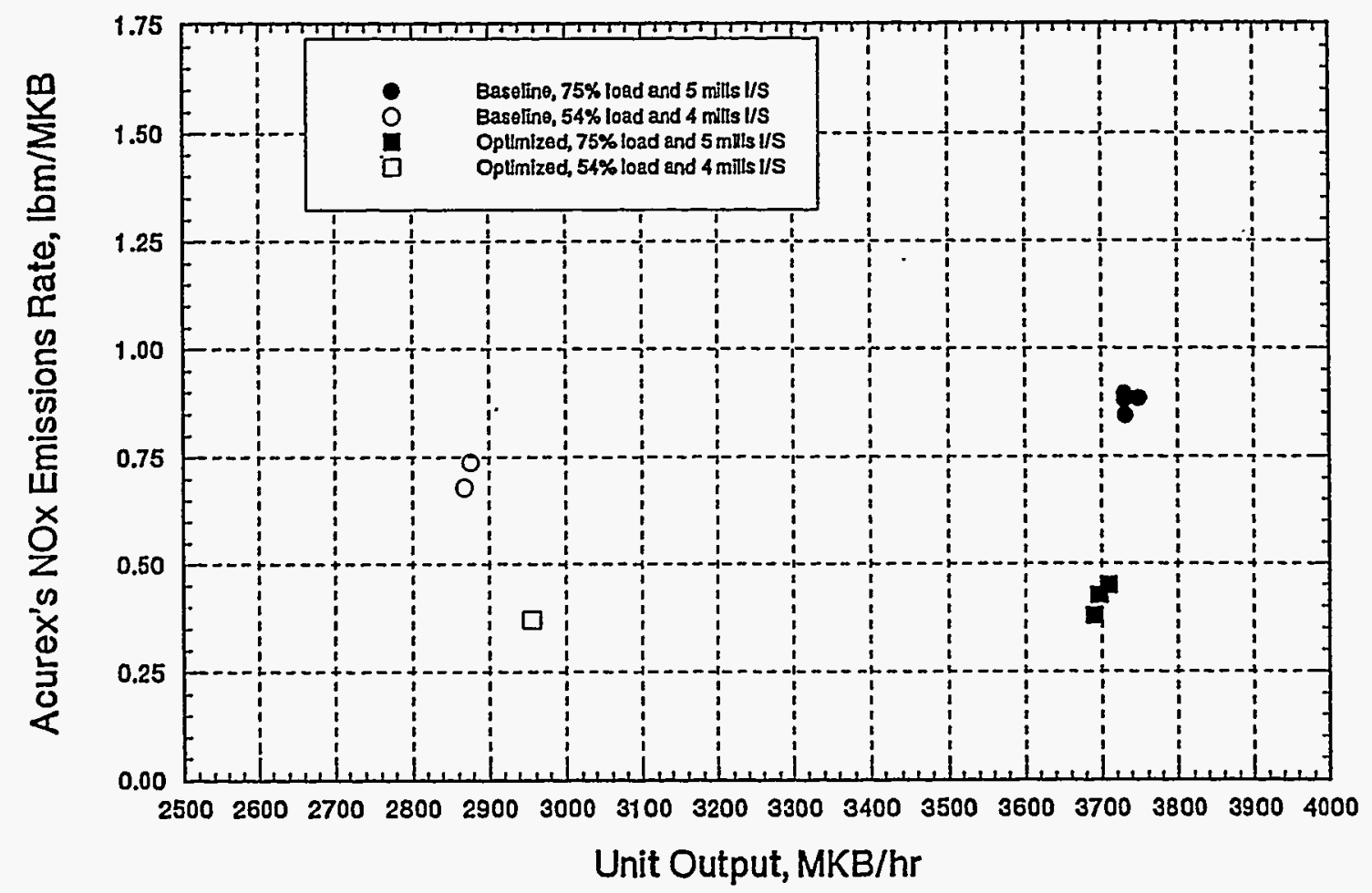

Figure 5-4 $\mathrm{NO}_{\mathrm{x}}$ emissions versus unit output at intermediate and low load - Acurex data 


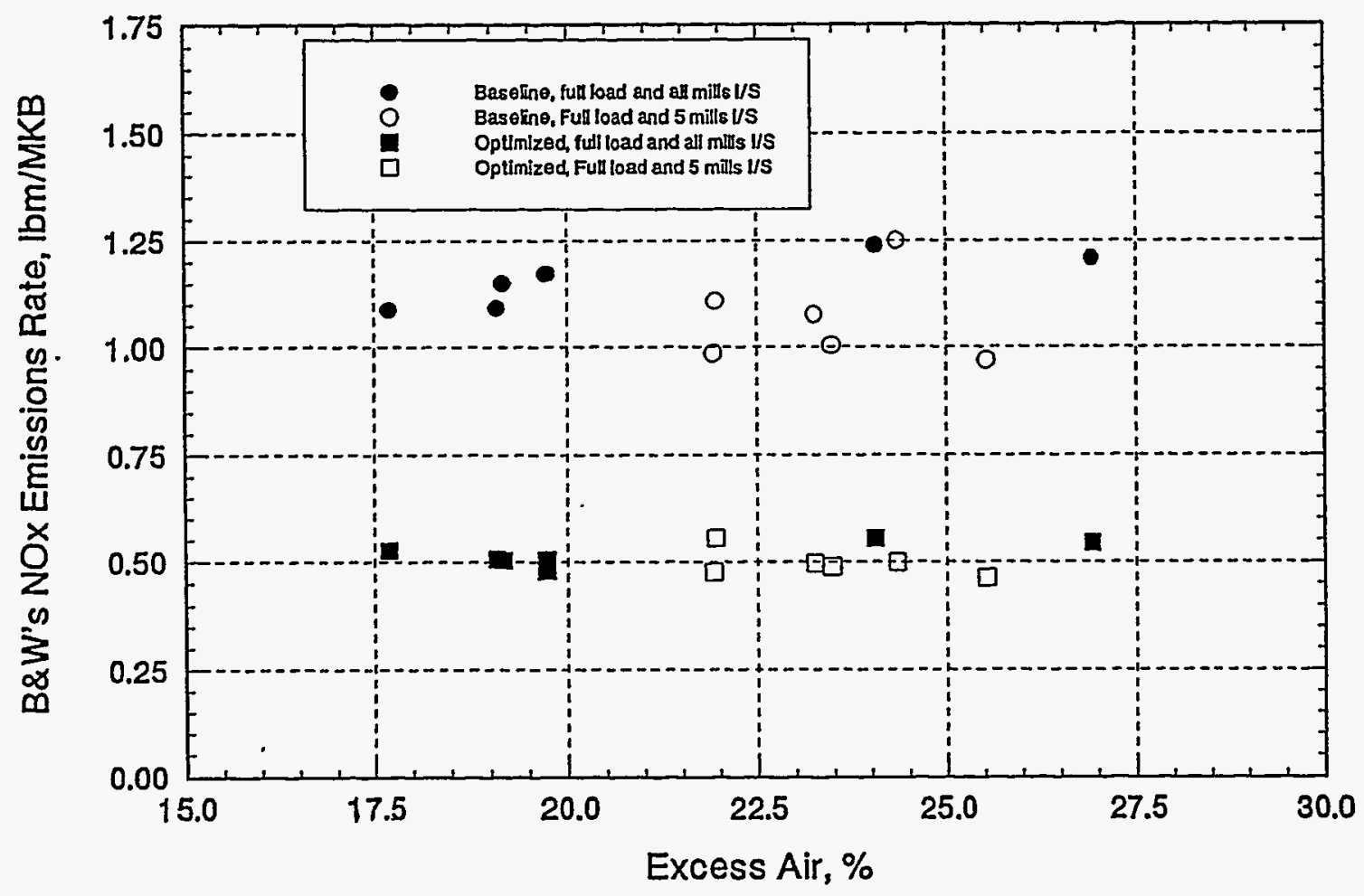

Figure 5-5 $\mathrm{NO}_{\mathrm{x}}$ emissions versus excess air at full load - B\&W data

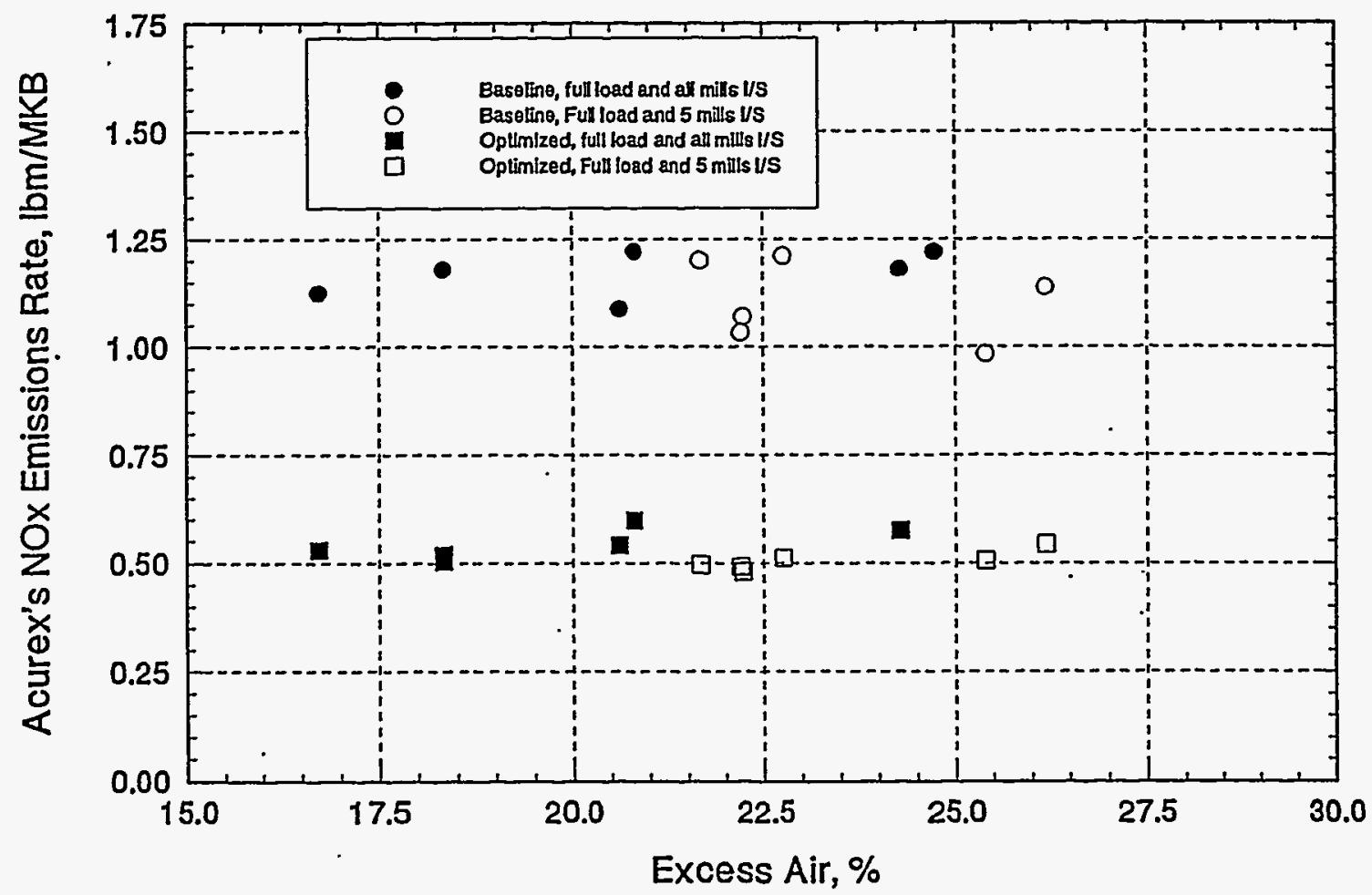

Figure 5-6 $\mathrm{NO}_{\mathrm{x}}$ emissions versus excess air at full load - Acurex data 


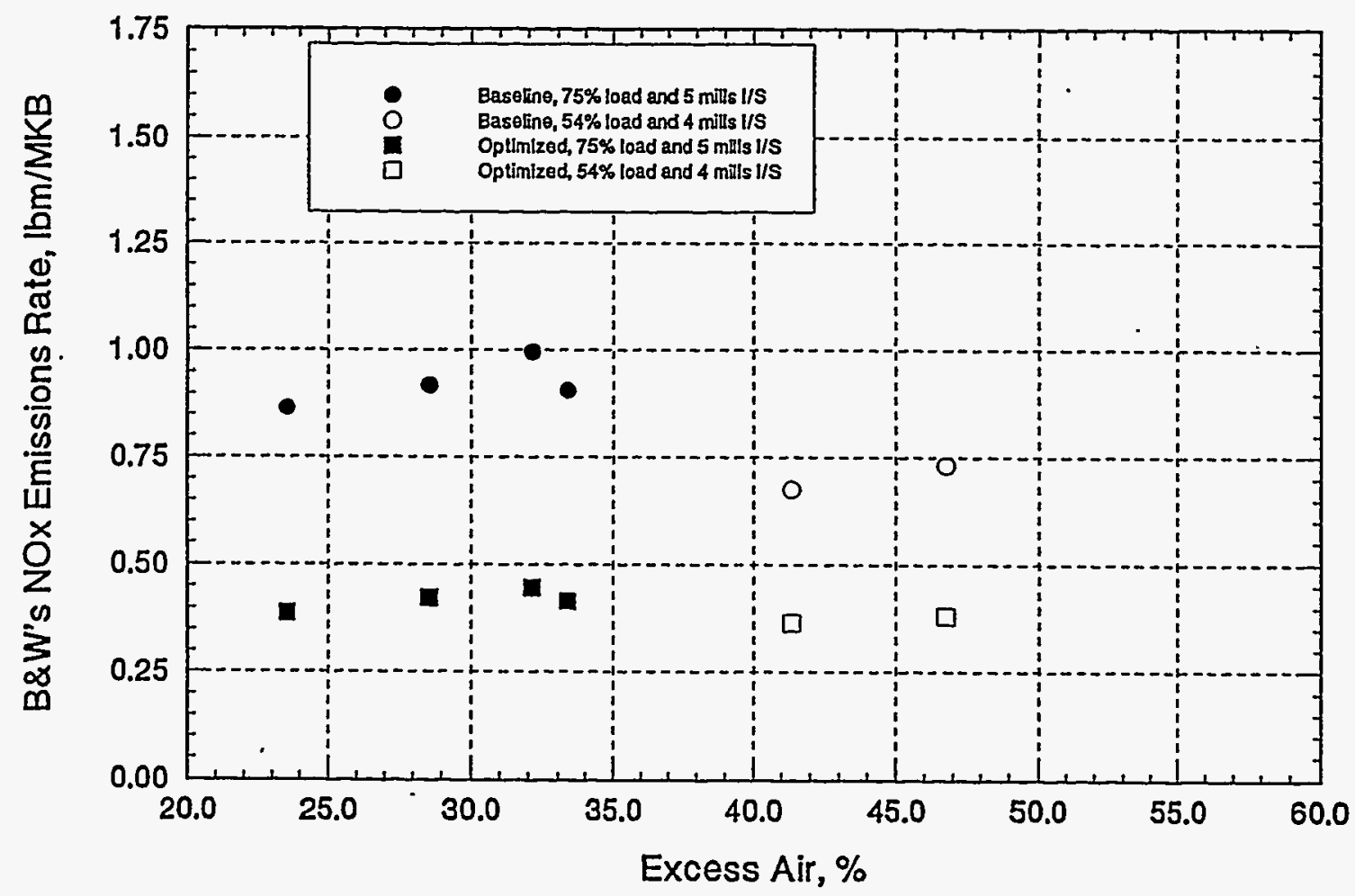

Figure 5-7 $\mathrm{NO}_{\mathrm{x}}$ emissions versus excess air at intermediate and low load $-\mathrm{B} \& \mathrm{~W}$ data

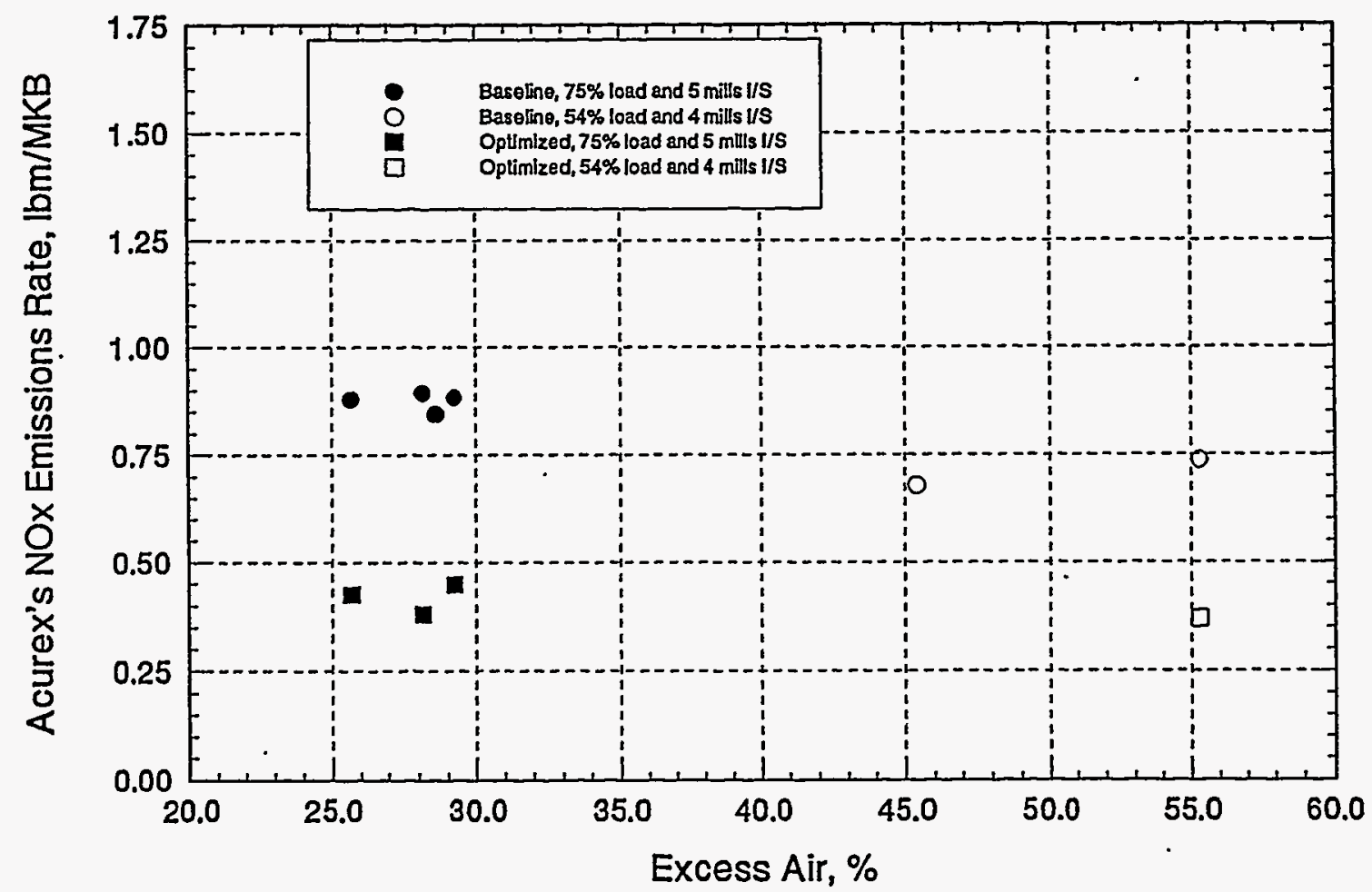

Figure 5-8 $\mathrm{NO}_{\mathrm{x}}$ emissions versus excess air at intermediate and low load - Acurex data 


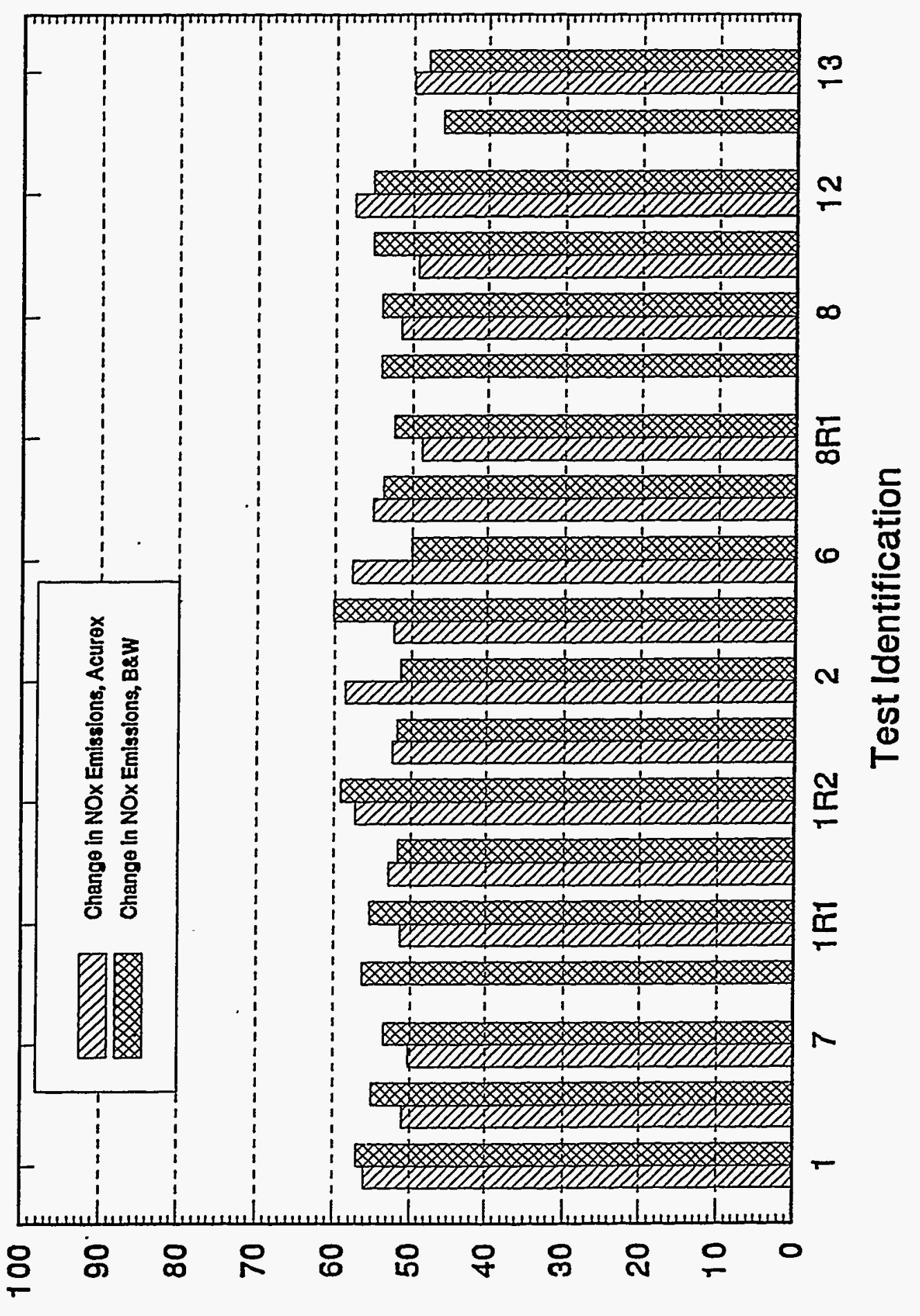

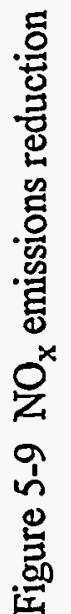




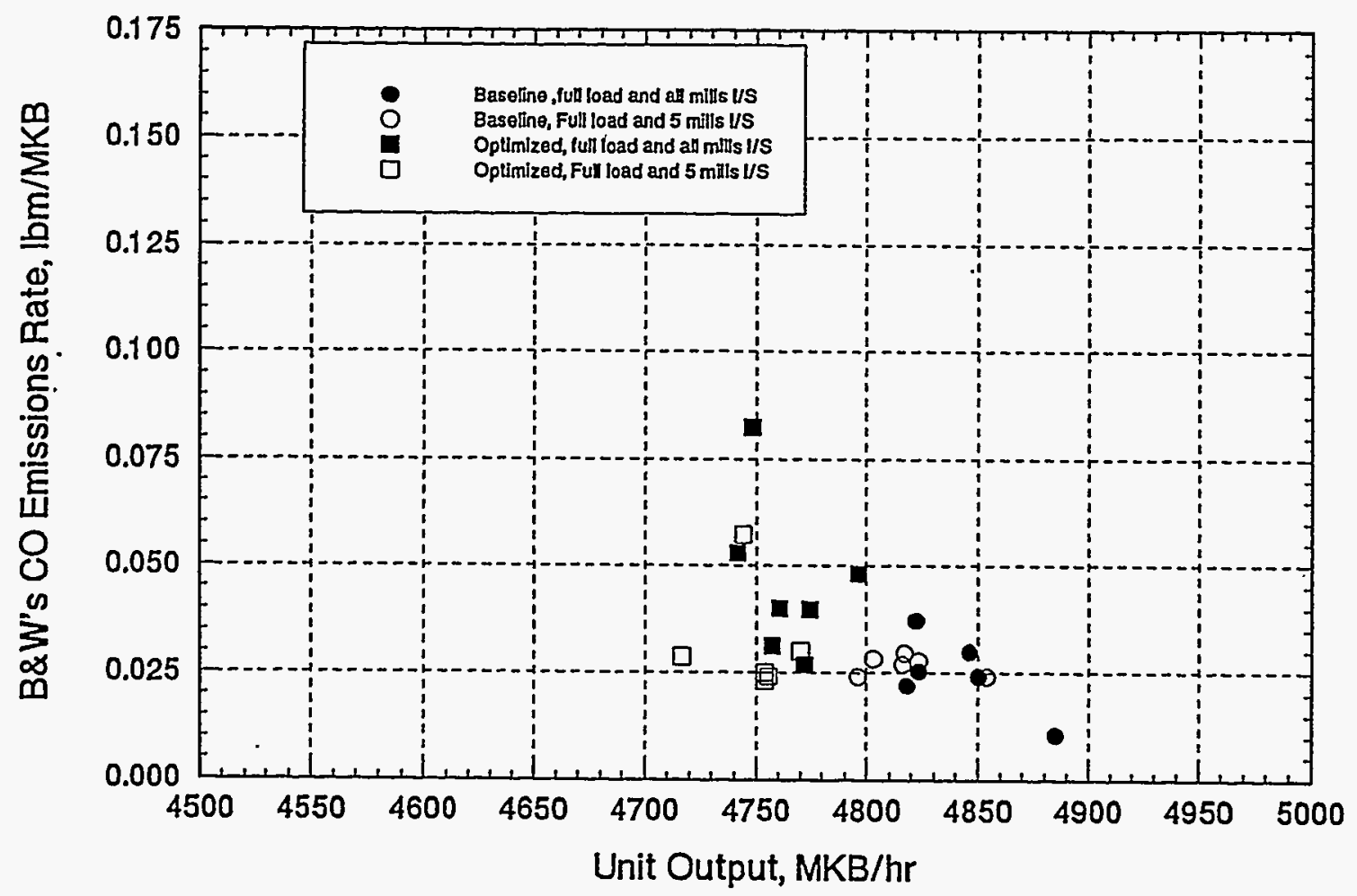

Figure 5-10 CO emissions versus unit output at full load $-\mathrm{B} \& W$ data

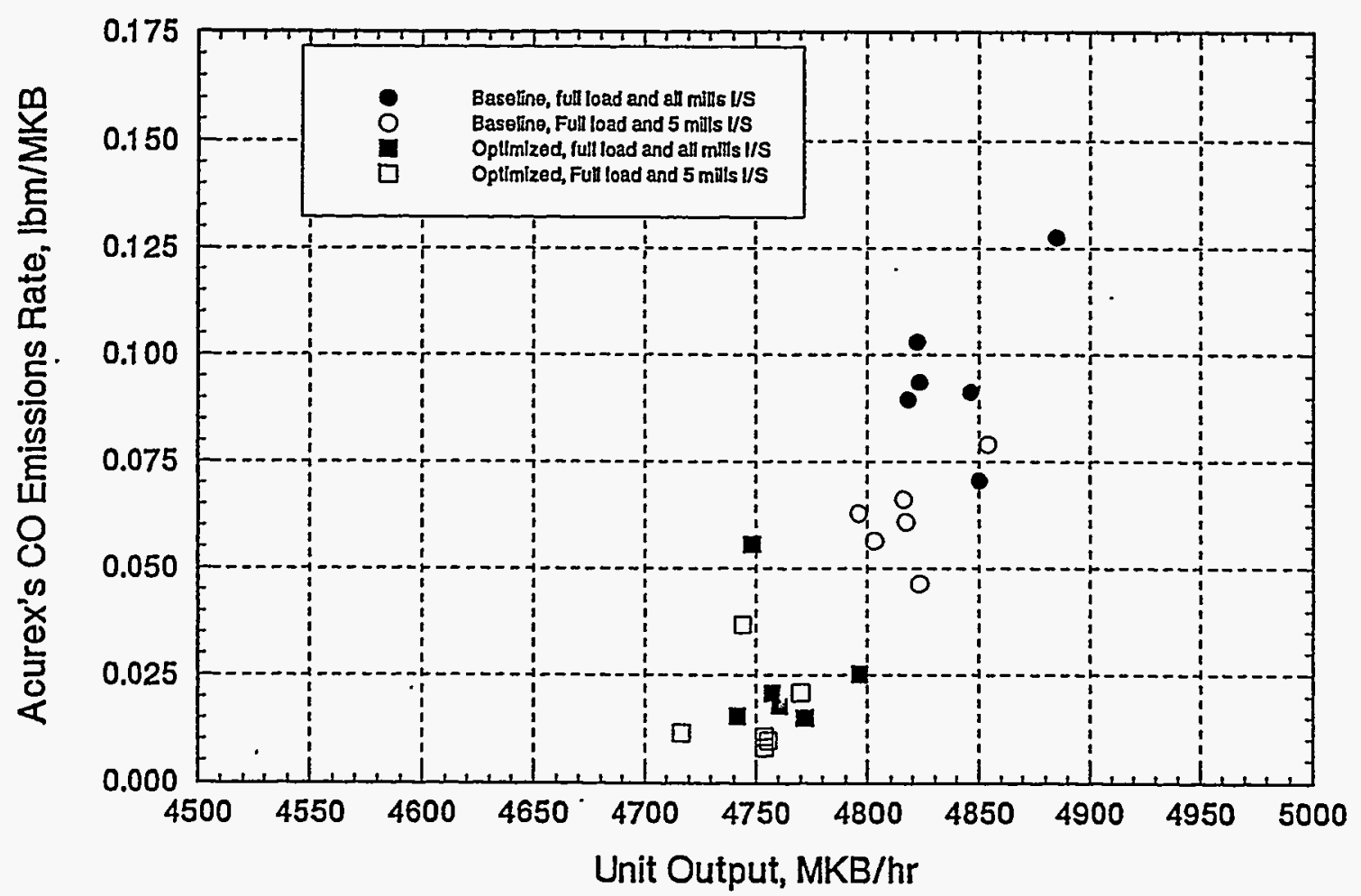

Figure 5-11 CO emissions versus unit output at full load - Acurex data 


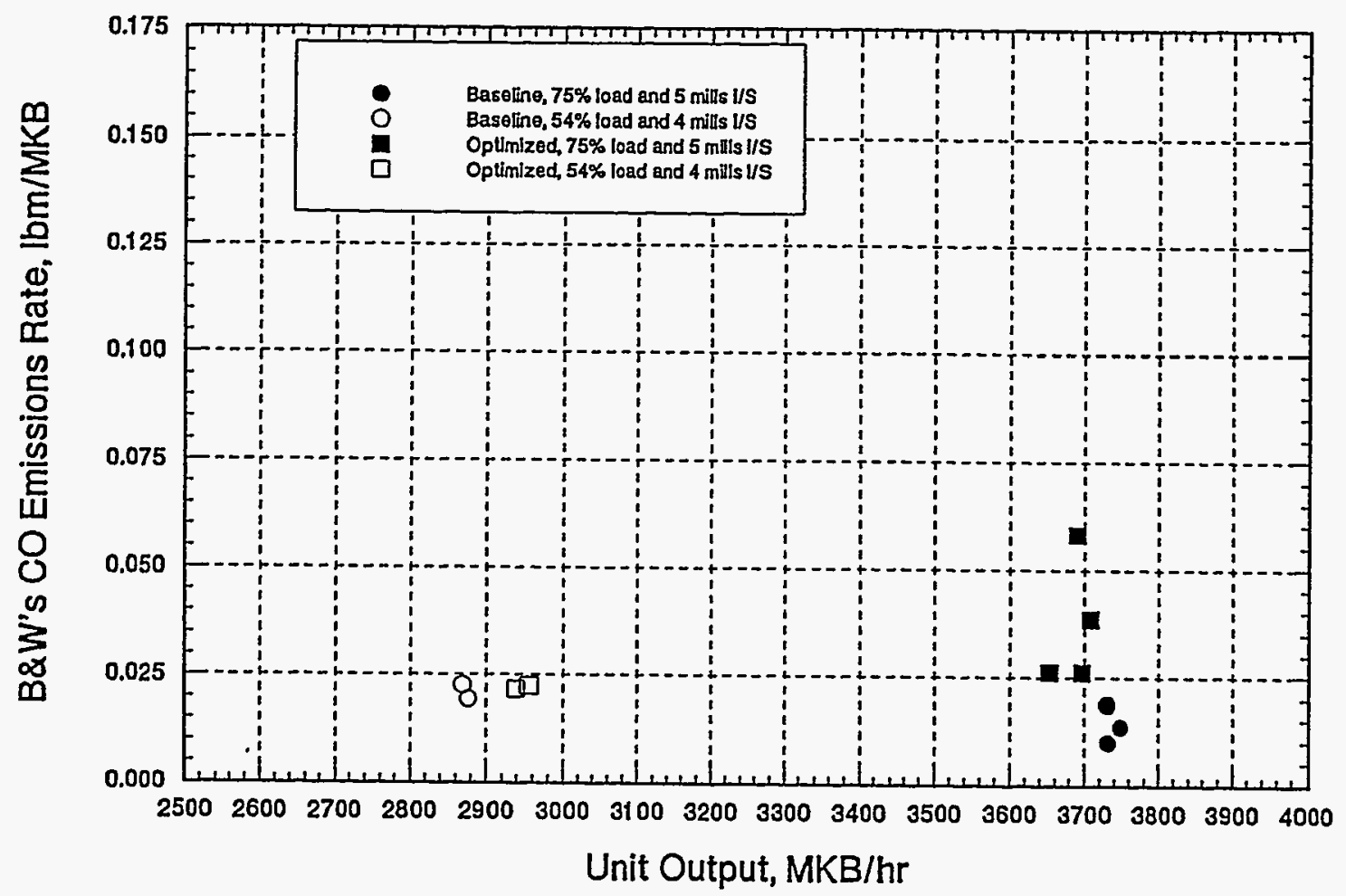

Figure 5-12 $\mathrm{CO}$ emissions versus unit output at intermediate and low load $-\mathrm{B} \& \mathrm{~W}$ data

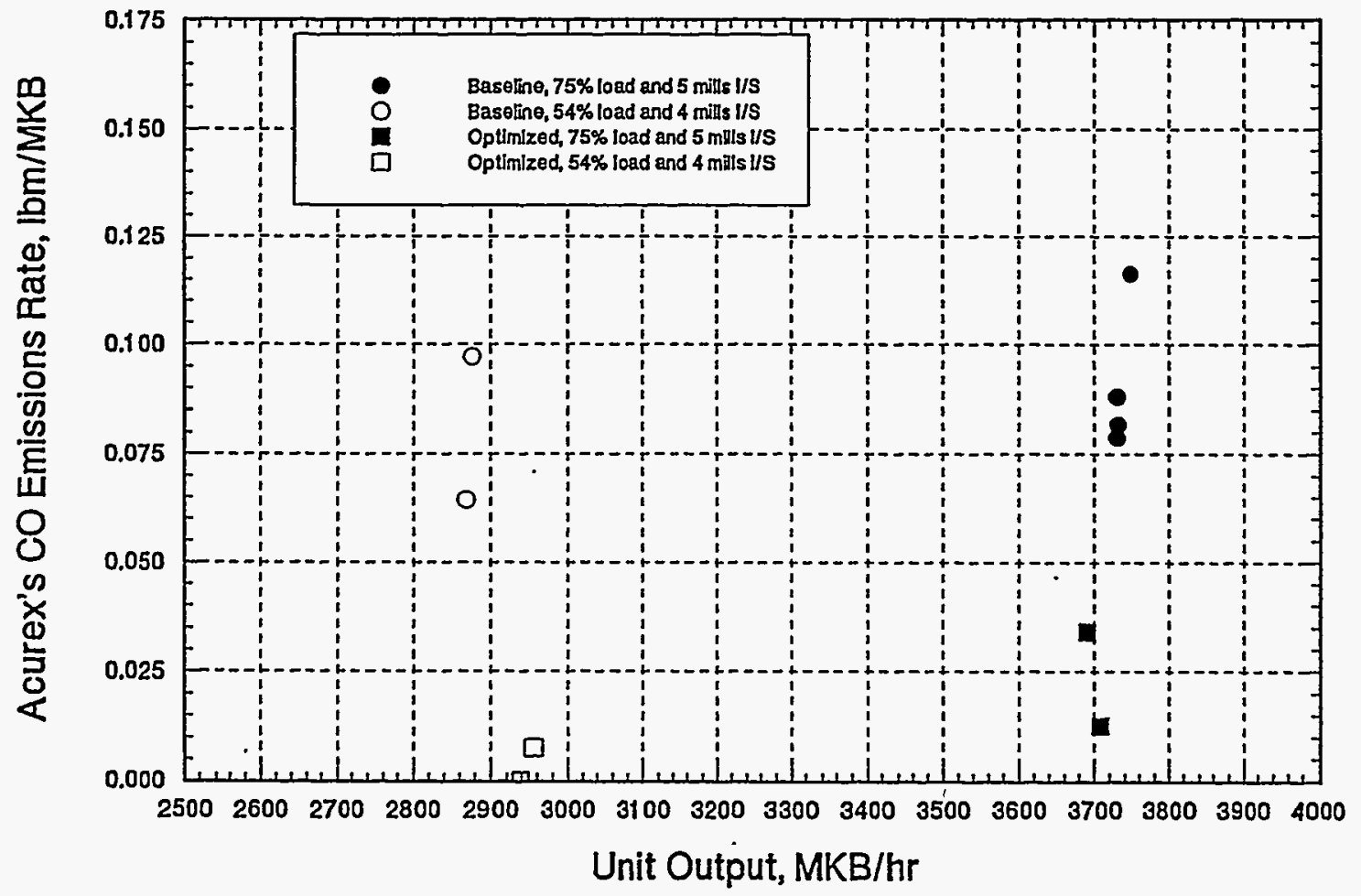

Figure 5-13 CO emissions versus unit output at intermediate and low load - Acurex data 


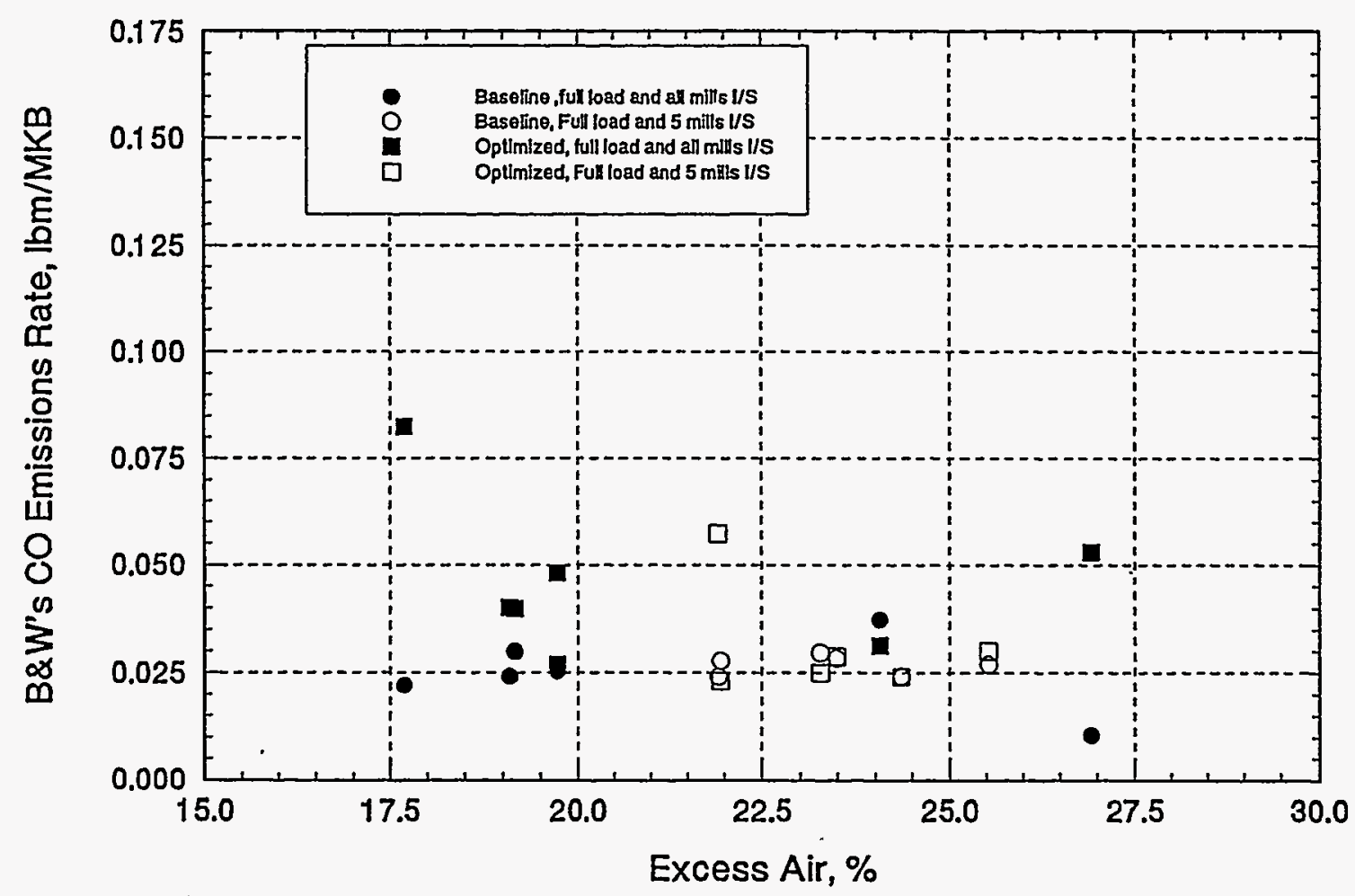

Figure 5-14 CO emissions versus excess air at full load $-\mathrm{B} \& W$ data

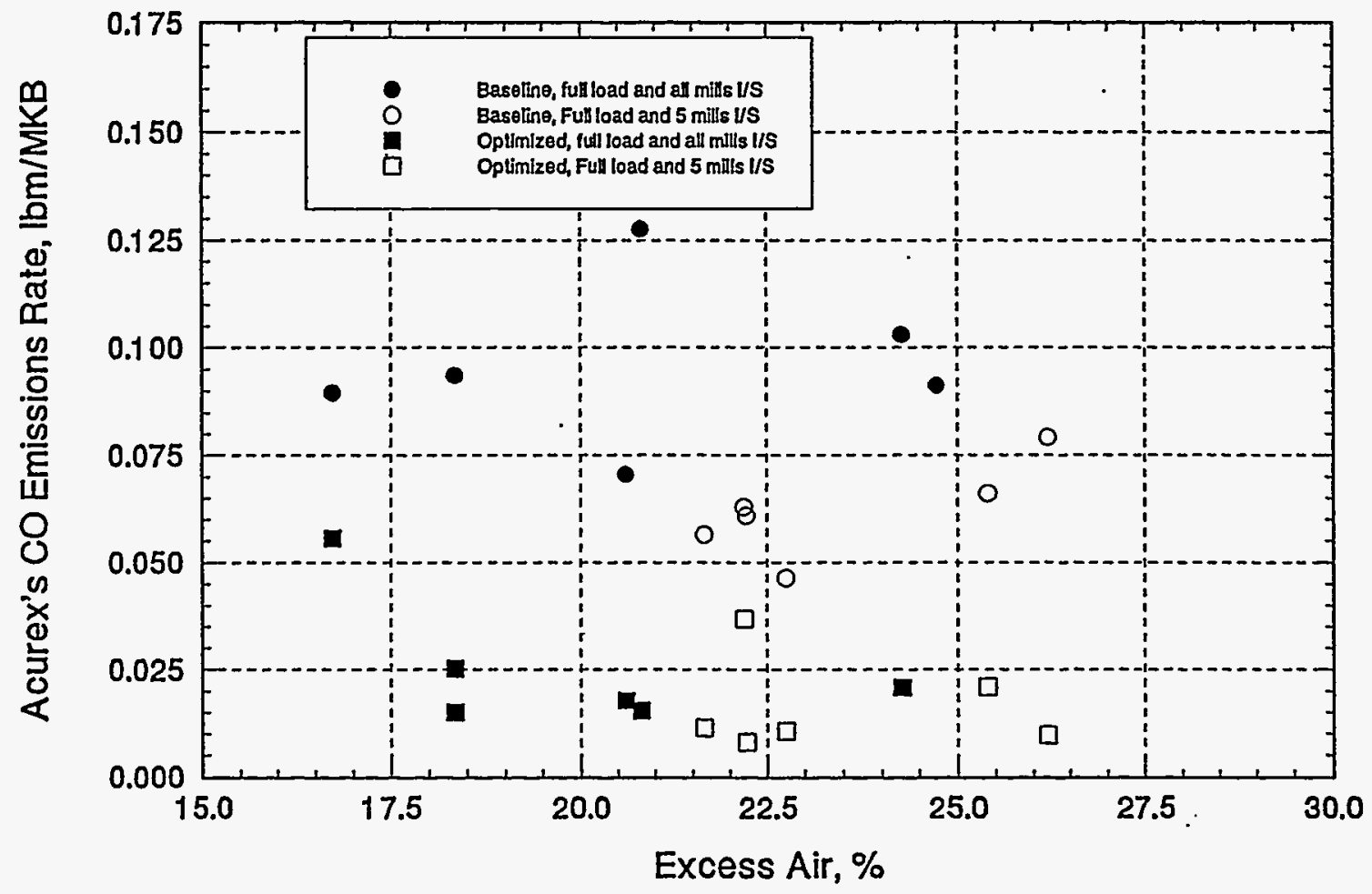

Figure 5-15 CO emissions versus excess air at full load - Acurex data 


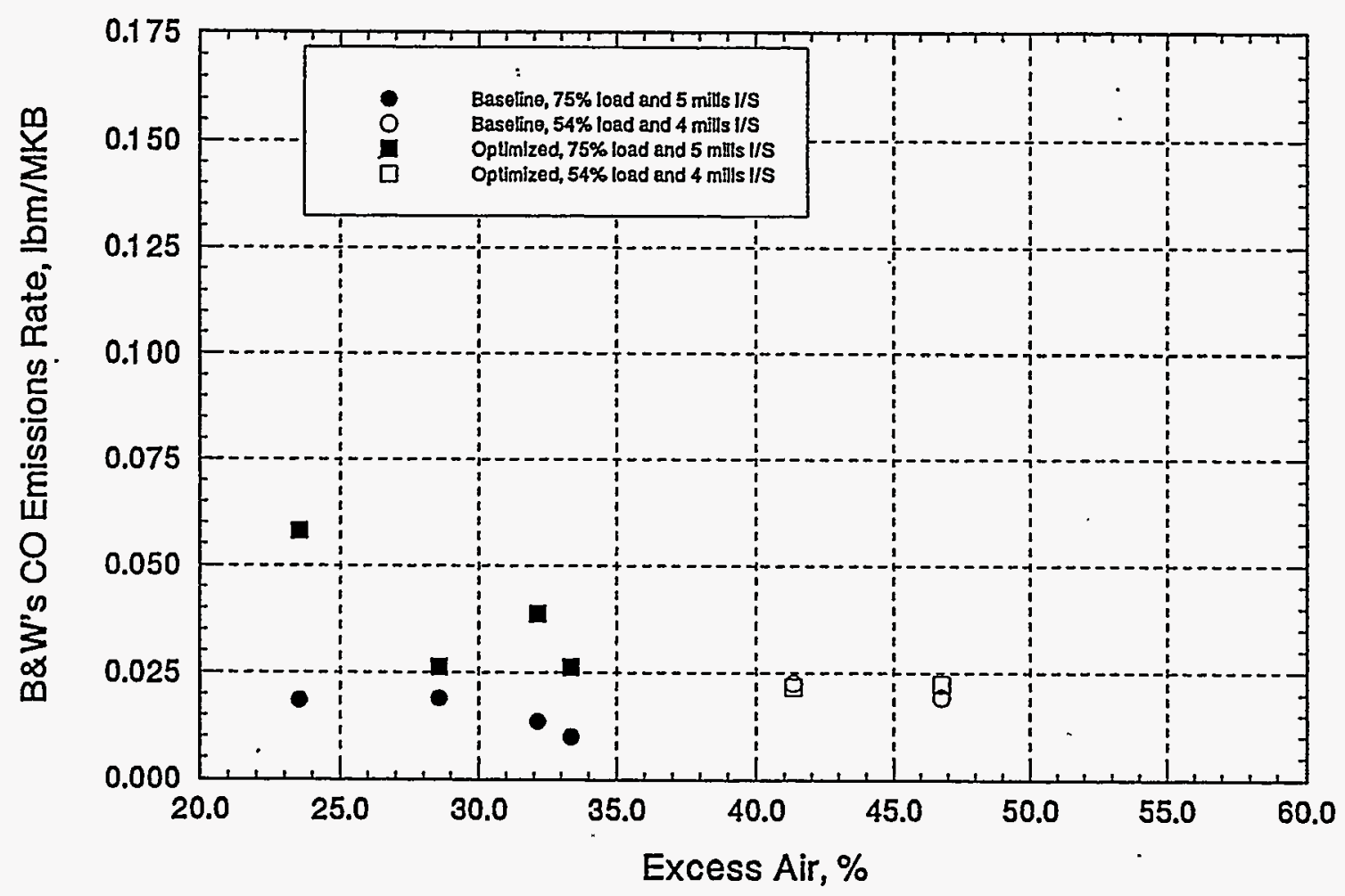

Figure 5-16 CO emissions versus excess air at intermediate and low load $-\mathrm{B} \& \mathrm{~W}$ data

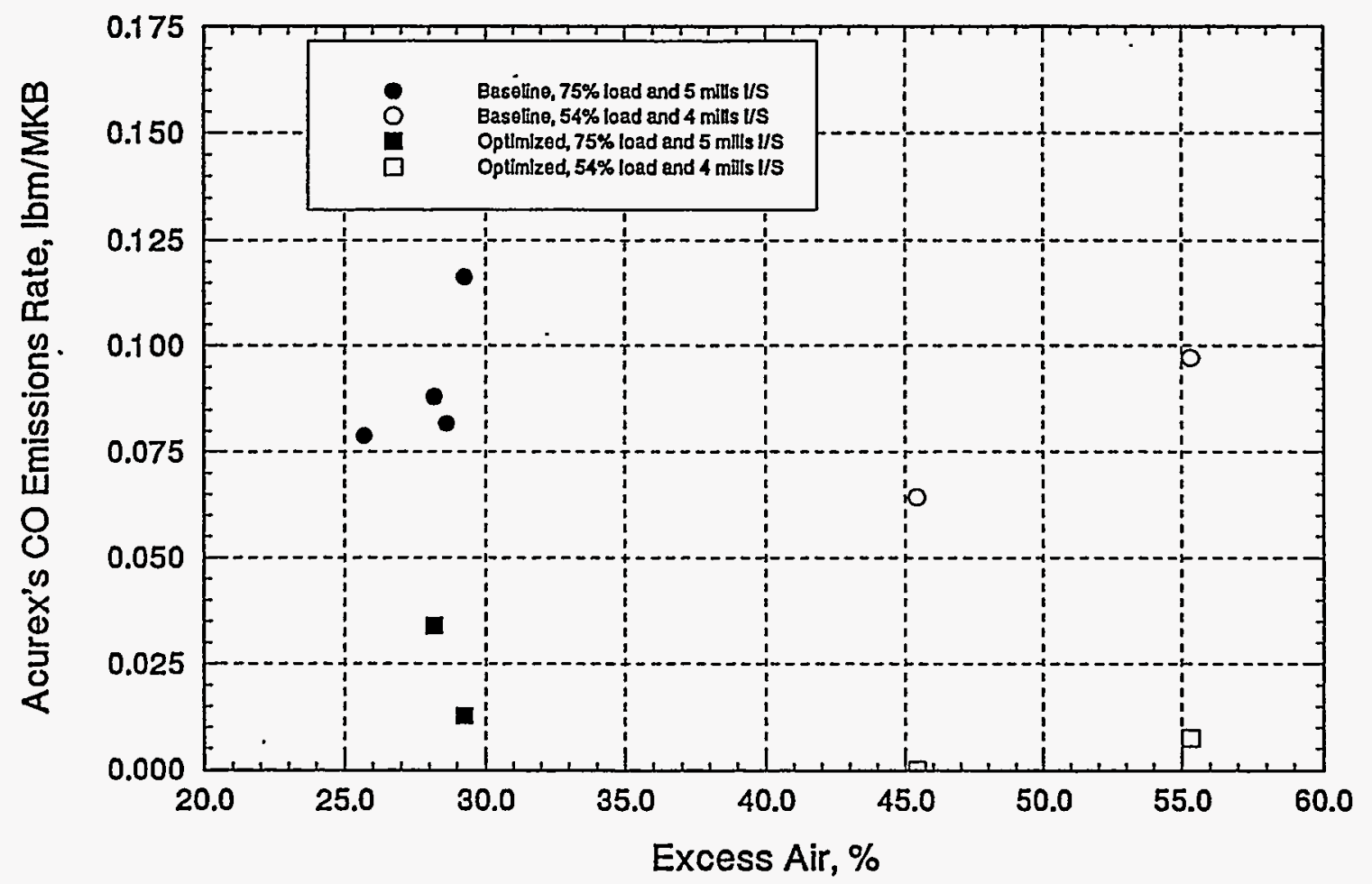

Figure 5-17 CO emissions versus excess air at intermediate and low load - Acurex data 


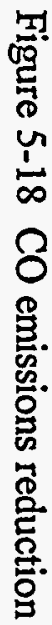

Change in CO Emissions Rate, \% of Baseline

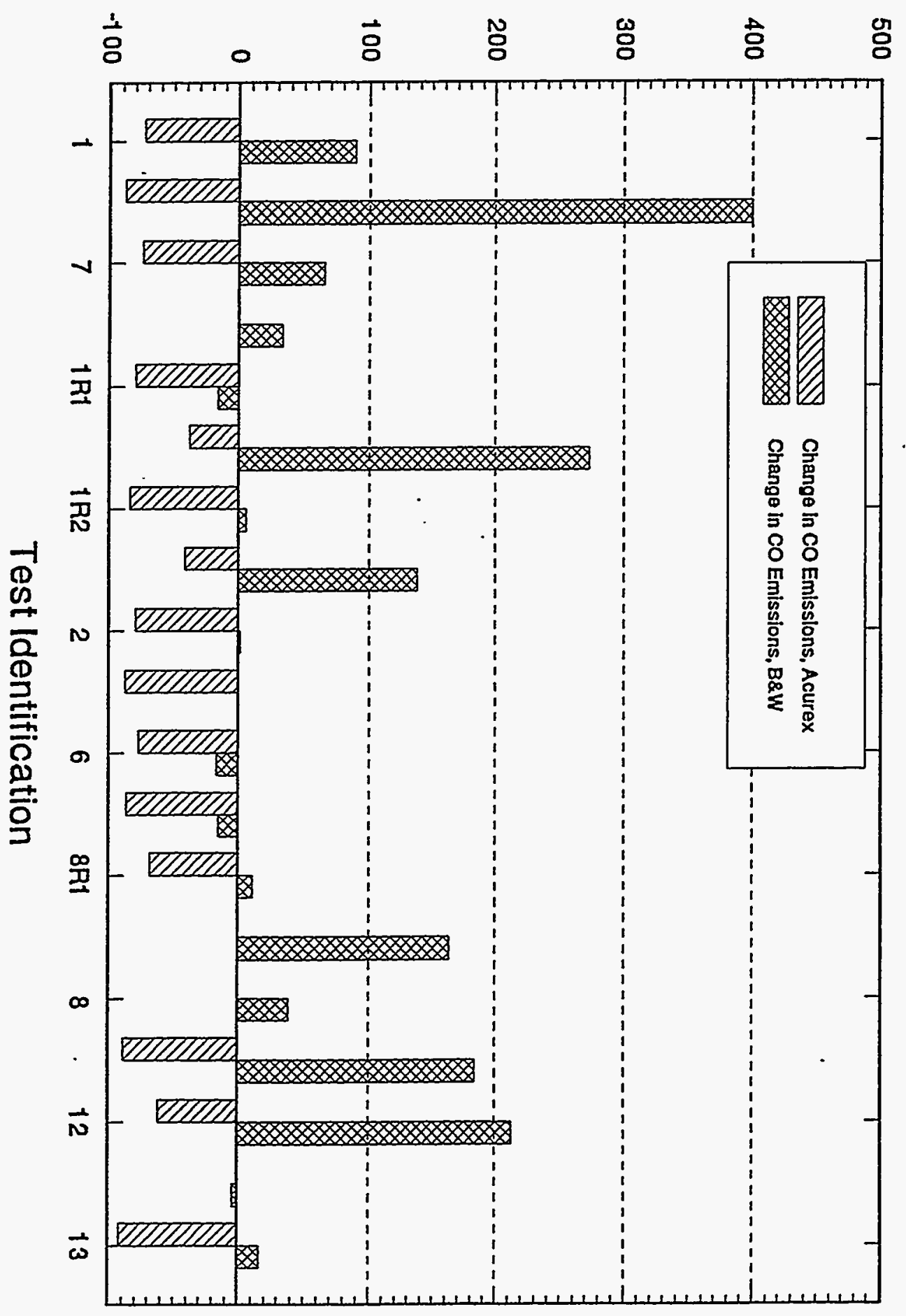


The percentage change from baseline to optimized conditions showed a considerable degree of disparity between $\mathrm{B} \& W$ and Acurex data. It originated from baseline testing where a large discrepancy in CO data appeared. The cause of this discrepancy was attributed to the unusually high calibration gas $\mathrm{CO}$ concentration used by both companies. Calibration gases had a $\mathrm{CO}$ content of up to $1000 \mathrm{ppm}$, however, measured CO levels were less than $100 \mathrm{ppm}$. Therefore, for optimization testing, an additional low CO concentration calibration gas was employed by both companies to more accurately calibrate the instruments. Consequently, results from optimzation tests were considerably improved.

5.2.3.3 $\mathrm{H}_{2} \mathrm{~S}$ Measurements. Under substoichiometric combustion of sulfur-containing coal, sulfidation becomes the primary corrosion mechanism attacking the furnace wall surfaces. Metal wastage caused by sulfidation is typically more severe than that caused by oxidation experienced in conventional boilers. Therefore, (substoichiometric) combustion gases in JMSS4 retrofitted with $\mathrm{LNCB}^{\mathrm{TM}}$ burners were expected to be more corrosive than those with standard cells. The $\mathrm{H}_{2} \mathrm{~S}$ present is a direct indication of the gas corrosivity by sulfidation. Therefore, the corrosion propensity is directly governed by the coal's sulfur content since it is converted primarily to $\mathrm{H}_{2} \mathrm{~S}$ in the substoichiometric combustion gases.

As mentioned previously, an on-line $\mathrm{H}_{2} \mathrm{~S}$ monitoring system for the furnace interior was developed by $\mathrm{B} \& \mathrm{~W}$ for pre- and post-retrofit testing using a sustained gas sampling probe. Details of the probe's design, sampling procedures, and test results were discussed in the Long-Term Testing Report issued earlier.

$\mathrm{H}_{2} \mathrm{~S}$ concentrations measured from four sampling ports on the corrosion test panel ranged from 20 to 839 ppmV during post-retrofit testing in June 1992. After burner optimization in August 1992, however, $\mathrm{H}_{2} \mathrm{~S}$ levels detected from three of the four sampling ports were reduced to less than $200 \mathrm{ppmV}$, which is the lower detection limit of the gas chromatograph (GC), while those from the fourth port at the lower right corner of the test panel were still at approximately $95 \mathrm{ppmV}$. The higher $\mathrm{H}_{2} \mathrm{~S}$ concentration measured from this location suggested that corrosive combustion gases might have existed locally adjacent to this furnace wall area.

5.2.3.4 Particulate Emissions. Acurex obtained dust loading data from several tests to determine ESP collection efficiencies under various operating conditions and to compare them to those of baseline conditions. Particulate emissions were measured for three load conditions:

- Full load with all mills in service

- Full load with Mill A out of service

- Intermediate load with Mill A out of service

Test results indicated virtually no change in precipitator performance. Dust loading values and collection efficiencies are tabulated in Table 5-3.

Acurex obtained in situ flyash resistivity data at the east airheater outlet downstream of the $\mathrm{SO}_{3}$ injection point. Flyash resistivity upstream of the $\mathrm{SO}_{3}$ injection was not measured. For the three high dust loading tests, spark resistivity ranged from $5.8 \times 10^{10}$ to $2.7 \times 10^{11} \mathrm{ohm}-\mathrm{cm}$ with an average of $1.7 \times 10^{11} \mathrm{ohm}$ $\mathrm{cm}$. In comparison, dust resistivity from seven full-load tests during baseline testing was $3.0 \times 10^{11} \mathrm{ohm}$ $\mathrm{cm}$. Flyash resistivity measured from the intermediate load tests averaged $2.3 \times 10^{11} \mathrm{ohm}-\mathrm{cm}$ and that from the low load test was $5.1 \times 10^{11} \mathrm{ohm}-\mathrm{cm}$. 
Table 5-3

PRECIPITATOR PERFORMANCE

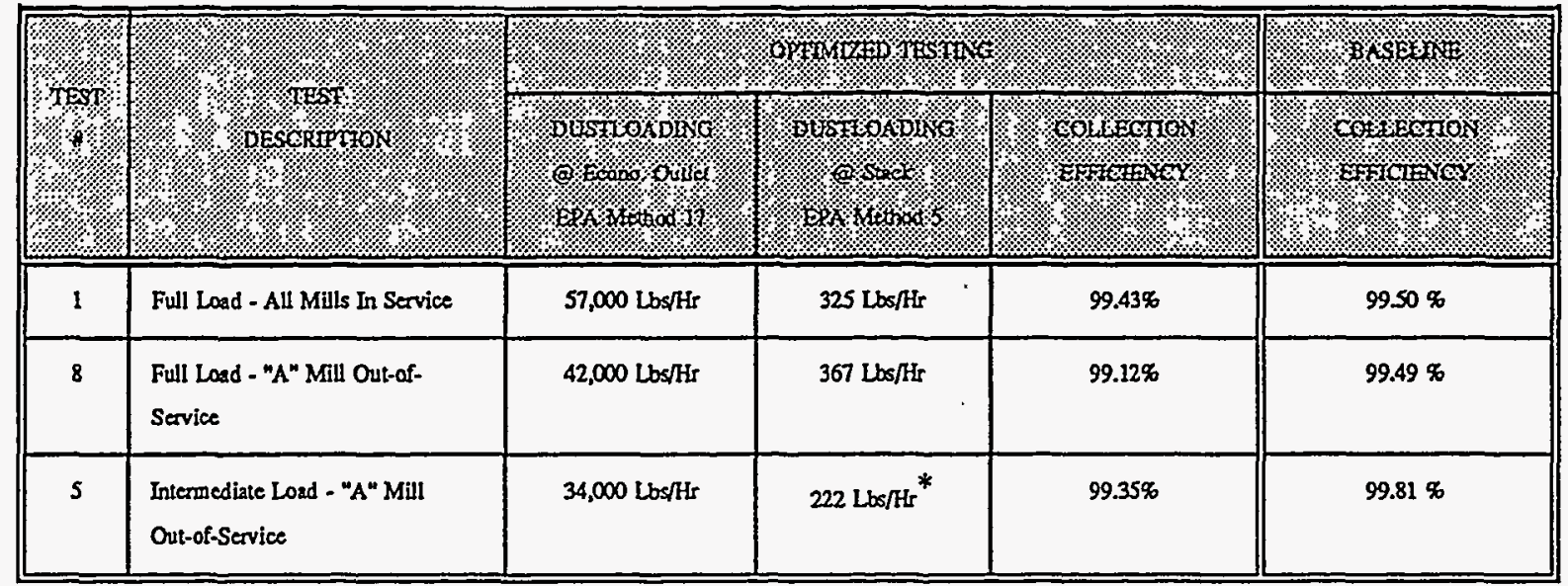

* - Corresponding baseline value unusually low (69 Lbs/Hr)

As a result, the $L N C B^{\mathrm{TM}}$ burner retrofit had not significantly affected flyash resistivity which would otherwise have a direct impact on ESP performance. Flyash resistivity was lowered by nearly two orders of magnitude through $\mathrm{SO}_{3}$ injection during the baseline testing, and the same level of resistivity reduction must have been achieved during optimized testing as well.

5.2.3.5 Boiler Flyash Particle Size. Eight economizer flyash samples were analyzed for particle size distribution using the same method as described in Section 2.2.5 for baseline testing. The mass median size of flyash samples ranged from 13.5 to $25 \mu \mathrm{m}$ for the optimization testing, with all particles having diameters less than $75 \mu \mathrm{m}$. The mass median size of flyash was lower than that of the corresponding baseline testing by as much as $67 \%$. Analyses showed that particle size did not vary significantly with the boiler load and mills out of service, as it did for baseline testing.

5.2.4 Boiler Performance. Because $\mathrm{NO}_{x}$ reduction could only be considered successful if overall boiler performance was not affected, several key operating parameters were carefully examined before and after the burner retrofit. Results showed that boiler performance was not significantly changed, as will be discussed below. For additional information, refer to the Optimized Testing Interim Report.

5.2.4.1 Reheater Steam Temperature Control. Reheater steam outlet temperature was controllable to the designed $1005 \pm 10^{\circ} \mathrm{F}$ for full load tests. At intermediate load, the steam outlet temperature was controlled with excess air; the average steam temperature was $979^{\circ} \mathrm{F}$ with a normal excess air level, $999^{\circ} \mathrm{F}$ with high excess air, and $959^{\circ} \mathrm{F}$ with low excess air. These temperatures represented a $19^{\circ} \mathrm{F}$ decrease from those of baseline testing. At the low load condition, reheater outlet temperature was $990^{\circ} \mathrm{F}$ with a normal excess air level, representing a $13^{\circ} \mathrm{F}$ increase from the baseline data.

Reheat spray flows were measured for all tests conducted. Reheat attemperation rates averaged 22.9 $\mathrm{klbs} / \mathrm{hr}$ for full load operation with all mills in-service, and $11.4 \mathrm{klbs} / \mathrm{hr}$ for the full load operation with one mill out-of-service. These flow rates were a decrease of approximately $30 \%$ from those of baseline testing. During intermediate and low load tests, there was no measurable attemperation flow.

Reheat attemperation has often been regarded as a costly expense due to attemperator spray flow entering the steam stream at a location after the high pressure turbine stage. The work that the attemperator spray flow could have been used in the turbine is therefore lost. Consequently, reducing reheater spray 
flow is considered an advantage if the unit is typically base loaded (>75\% of MCR) and control load is not a concern.

5.2.4.2 Furnace Exit Gas Temperature. The furnace exit gas temperature (FEGT) is defined for the region where flue gas leaves the furnace and enters the secondary superheater. This temperature can be determined by two methods - one analytical and the other by traversing with a special water-cooled probe.

The analytical method is based on a series of heat balances beginning with the average flue gas temperature measured with a thermocouple grid at the economizer outlet. By working upstream toward the furnace outlet, the average gas temperature entering each tube bank is determined using a series of heat transfer calculations. Heat gained by the working fluid (water or steam) equals the heat lost by the flue gas. The last heat transfer section in this series of calculations is the secondary superheater and the last, or superheater inlet gas temperature, is the FEGT.

A second method for determining FEGT is to use a water-cooled thermocouple probe. Because of the high temperatures present, radiant heat transfer becomes a major concern and special precautions must be taken. A bare thermocouple would indicate a lower than true gas temperature because of thermal radiation from the thermcouple to the cooler furnace wall and superheater tubes. To overcome this problem, it is necessary to shield the thermocouple junction with a high temperature ceramic sleeve then induce a gas flow rate equivalent to at least $15,000 \mathrm{lb} / \mathrm{hr}-\mathrm{ft}^{2}$ over the shield's outer surface to ensure that heat transfer from the flue gas to the thermocuple occurs by convection.

Ideally, several shields should be used and such a probe would be referred as a multiple-shielded high velocity thermocouple, or MHVT. MHVTs cannot be used in high ash loading environments so a single shield design is used and an adjustment applied to correct gas temperatures from HVT to MHVT values which correspond to analytically determined values as described above.

HVT traversing to establish FEGTs is somewhat limited in terms of being a true representation of a bulk or global gas temperature entering the superheater. For the most part, it is impractical because of the time required to conduct a full-plane traverse in this boiler region. This area could range from 60 to 80 feet wide by 20 to 30 feet. Secondly, coverage across the furnace's width is limited by probe length. With access from both boiler sidewalls, traversing is limited to a distance of about 20 to 22 feet in from each side. A major advantage of the HVT traversing technique, however, is that side-to-side temperature profiles provide a good indication of burner performance.

With these limitations in mind, B\&W considered calculated FEGTs to be more accurate than measured values for this test program. Figure 6-19 graphically depicts the variation of FEGTs with unit output for the baseline and optimization tests; Figure 6-20 compares baseline FEGTs to those under optimized conditions.

Results showed that FEGTs decreased as much as $100^{\circ} \mathrm{F}$ from those of baseline testing conditions during the early part of optimization testing. However, FEGTs later increased to within $10^{\circ} \mathrm{F}$ of the corresponding baseline data. This may be due to ash buildup on the furnace walls or changes in thermal emissivity. 


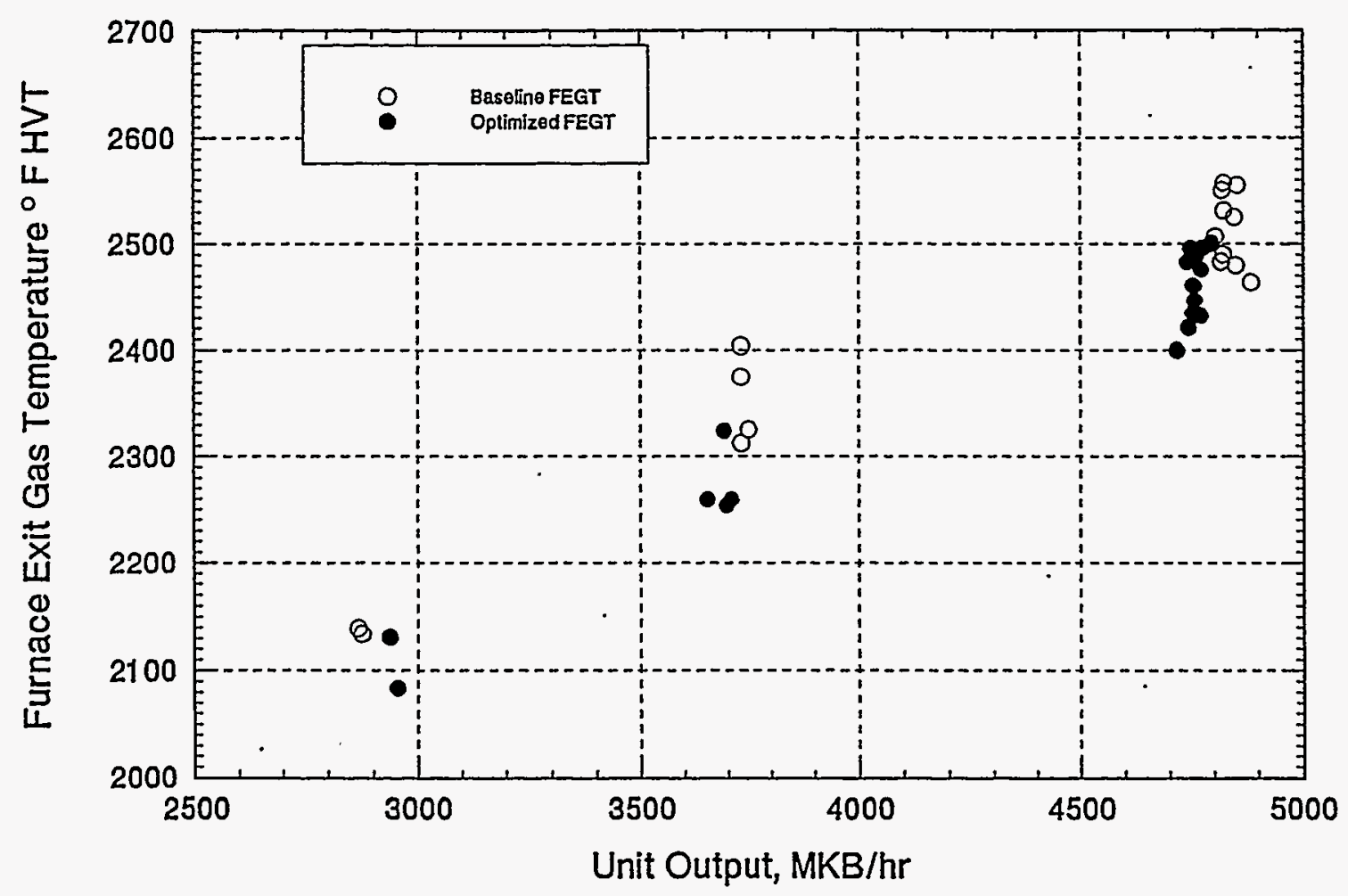

Figure 5-19 FEGT versus unit output

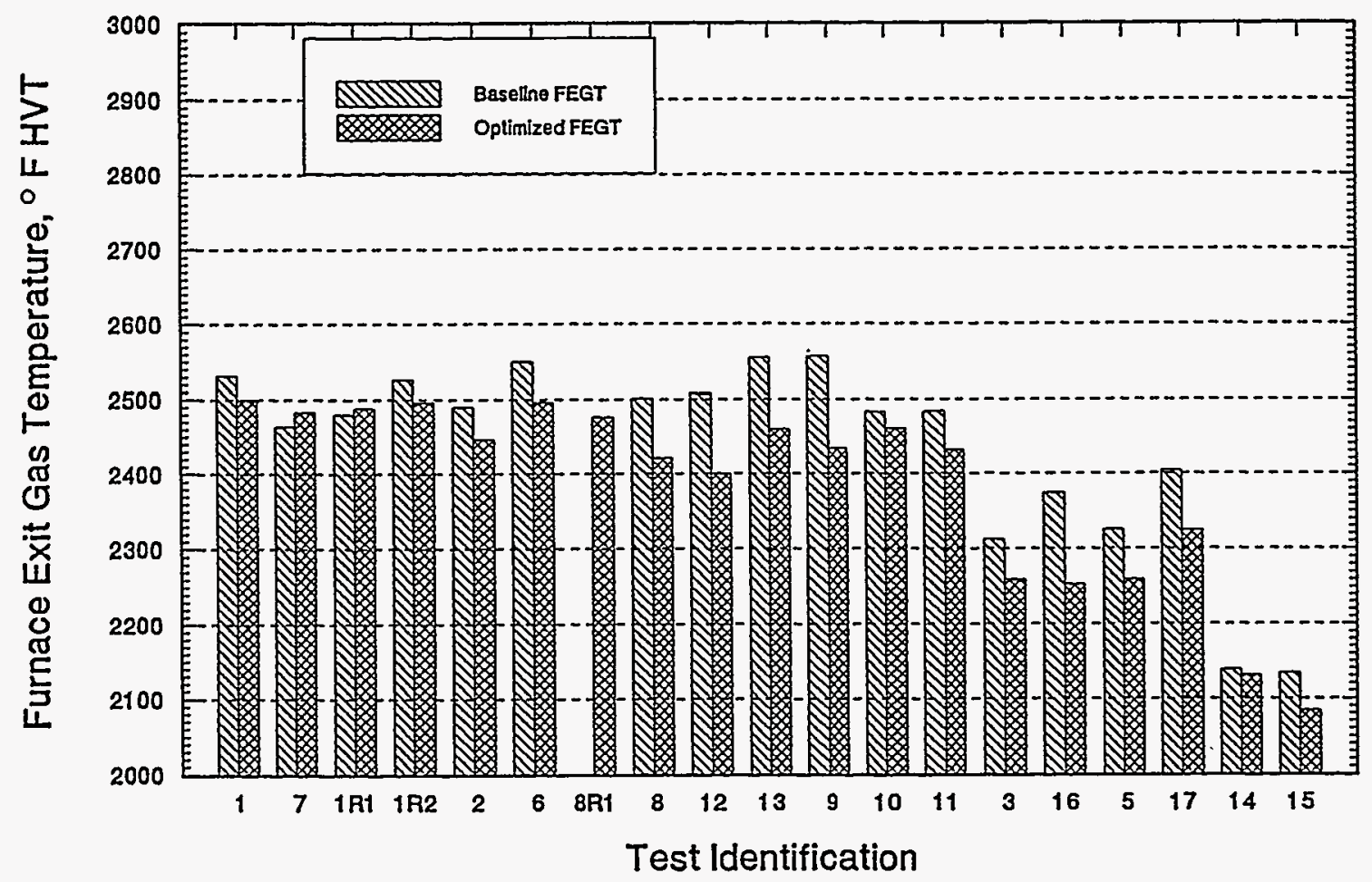

Figure 5-20 FEGT comparison 
5.2.4.3 Surface Cleanliness. During baseline testing, the only obvious decrease in $\mathrm{K}_{\mathrm{f}}$ was found on the SSH, where the ash layer caused an increase in the heat transfer resistance. Heat transfer of the inlet bank was more effective than that of the outlet bank, but as a whole, SSH performance met expectations. During the optimization testing, however, a reversed phenomenon was observed, i.e., the outlet bank was more effective than the inlet bank. Again, overall performance of SSH was not affected. Variations of $\mathrm{SSH} \mathrm{K}_{\mathrm{f}} \mathrm{s}$ for different tests are summarized in Figure 5-21.

Very few changes in cleanliness factors were found for the primary superheater, reheater, and economizer from baseline to optimized test conditions. Variation of $\mathrm{K}_{\mathrm{f}} \mathrm{s}$ with test identities are shown in Figure 5-22.

5.2.4.4 Unburned Carbon Loss. Ash samples were periodically collected from the boiler bottom ash hopper and the ESP first field hopper. Additional flue dust samples were collected by Acurex using an EPA Method 17 test probe. Unburned carbon loss generally increased by approximately $28 \%$ compared to that of baseline for all tests. The most significant increases occurred for tests with one mill out of service, with an average loss of $0.69 \%$ in efficiency at a $52 \%$ increase in unburned carbon loss from baseline conditions (see page A-3 for carbon-in-ash values).

\subsubsection{Efficiency Calculations}

Unit efficiency was determined from each data set using coal sample analyses for the corresponding test period. Average efficiency for full load with all mills in-service was $89.59 \%$ and that for full load with one mill out-of-service was $89.63 \%$. For intermediate load tests, unit efficiency averaged $90.12 \%$, while efficiency averaged $90.38 \%$.

Figure 5-23 compares baseline and optimization testing results. Generally, efficiency showed very little change from those of baseline conditions. The higher loss from unburned carbon was offset by a decrease in the dry gas loss due to a lower economizer outlet gas temperature and the ensuing decrease in air heater outlet gas temperature.

5.2.4.6 Coal Fineness. When firing coal with an HGI value of 40 in JMSS4, coal fineness averaged at 97.8\% through a USS 50 Mesh screen and 66.3\% through a USS 200 Mesh screen. When firing a coal with an HGI value of 41, average coal fineness was $95.4 \%$ through a USS 50 Mesh screen and $62.0 \%$ through a USS 200 Mesh screen. Compared to baseline results, these finenesses represented a $13 \%$ increase in coal passing through the USS $200 \mathrm{Mesh}$ screen. This increase was a consequence of mill maintenance performed during the outage.

The coal HGI (40) from optimized testing is lower than the original pulverizer design value (50), indicating that the coal was harder and essentially reduced pulverizer capacity by a factor of 0.82 . This reduction would have limited each pulverizer's capacity to $88,560 \mathrm{lbs} / \mathrm{hr}$. During the optimization tests, each pulverizer was grinding at approximately $80,000 \mathrm{lbs} / \mathrm{hr}$. If the pulverizers had been in their ideal operating condition, the percentage of coal passing through the USS $200 \mathrm{Mesh}$ screen would have been $70 \%$ or greater.

5.2.4.7 Burner Zone Stoichiometry Impact. The reduced stoichiometry at the burners lowered flame temperature and prolonged the combustion process. Once this was accomplished, the balance of combustion air was introduced through $\mathrm{NO}_{\mathrm{x}}$ ports to complete the combustion processes. 


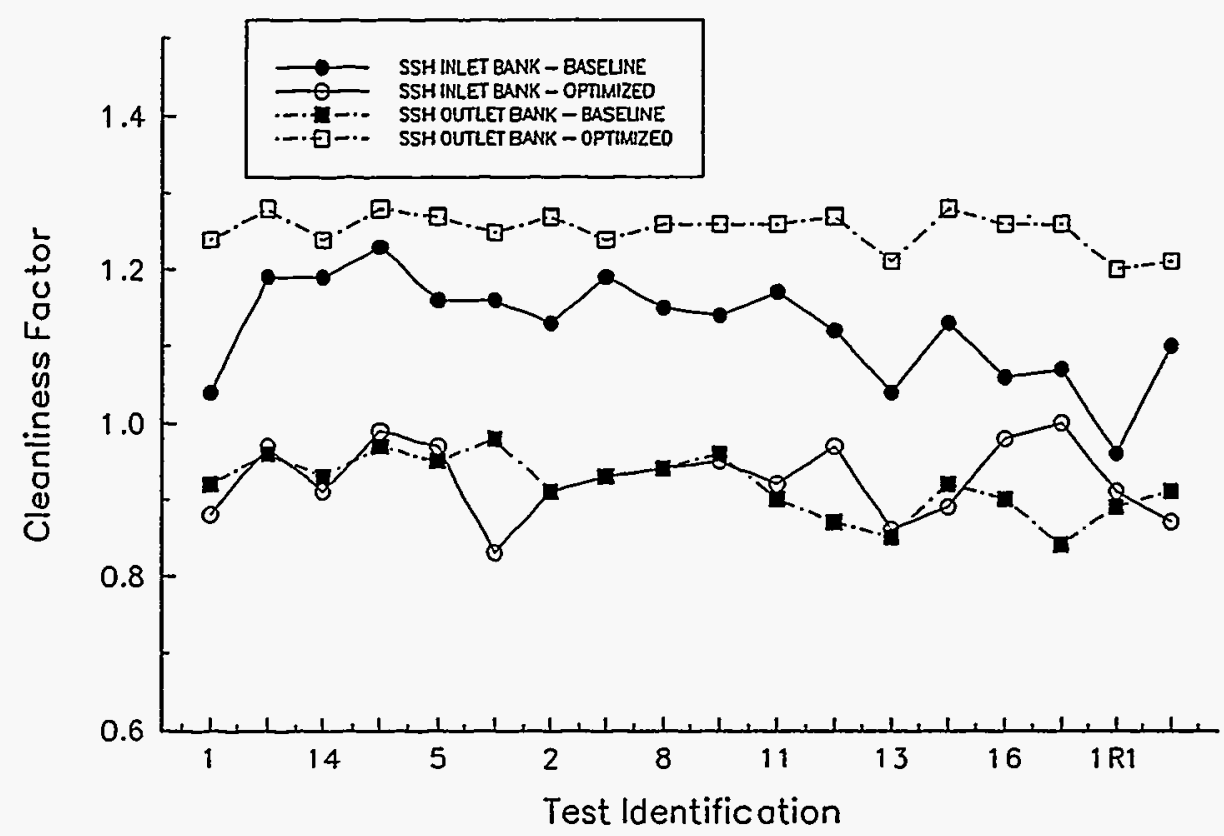

Figure 5-21 Secondary superheater $\mathrm{K}_{\mathrm{f}}$ comparison

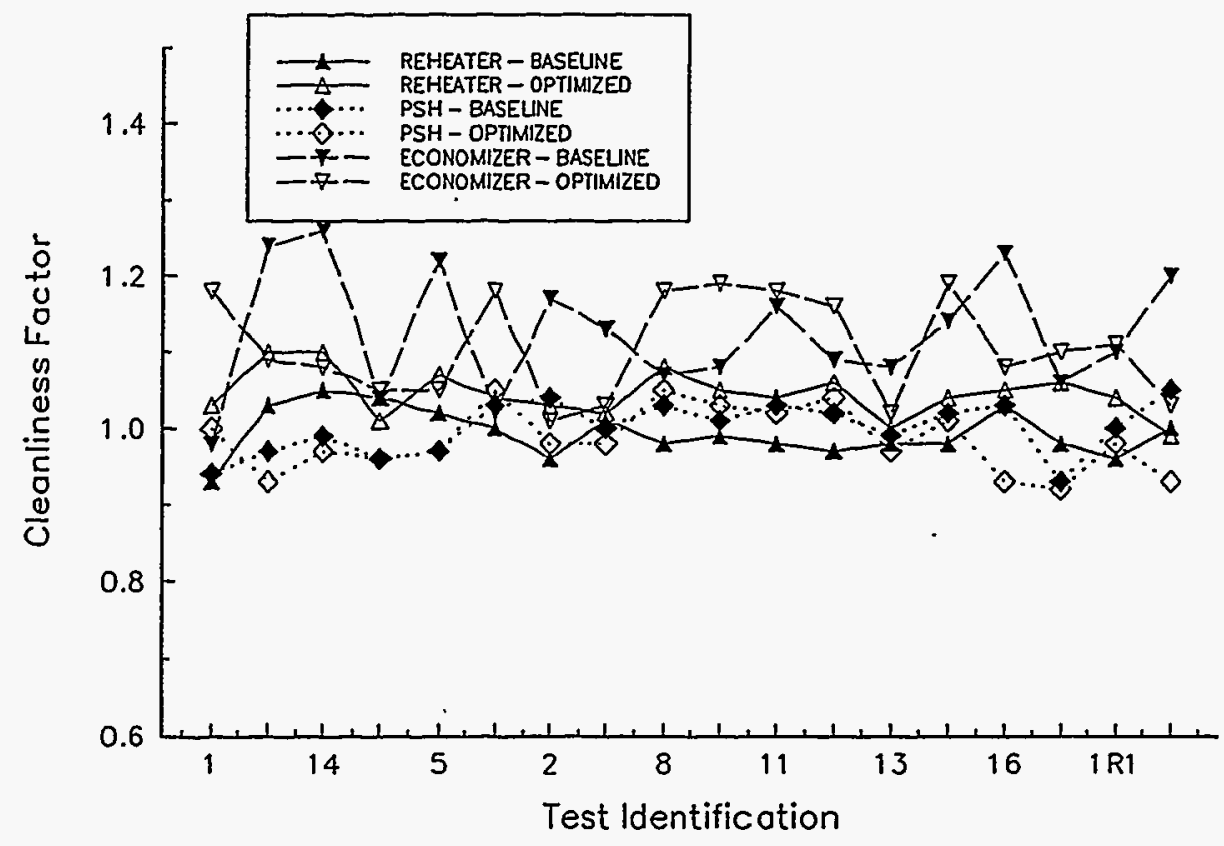

Figure 5-22 Reheater, primary $\mathrm{SH}$, and economizer $\mathrm{K}_{\mathrm{f}}$ comparison 


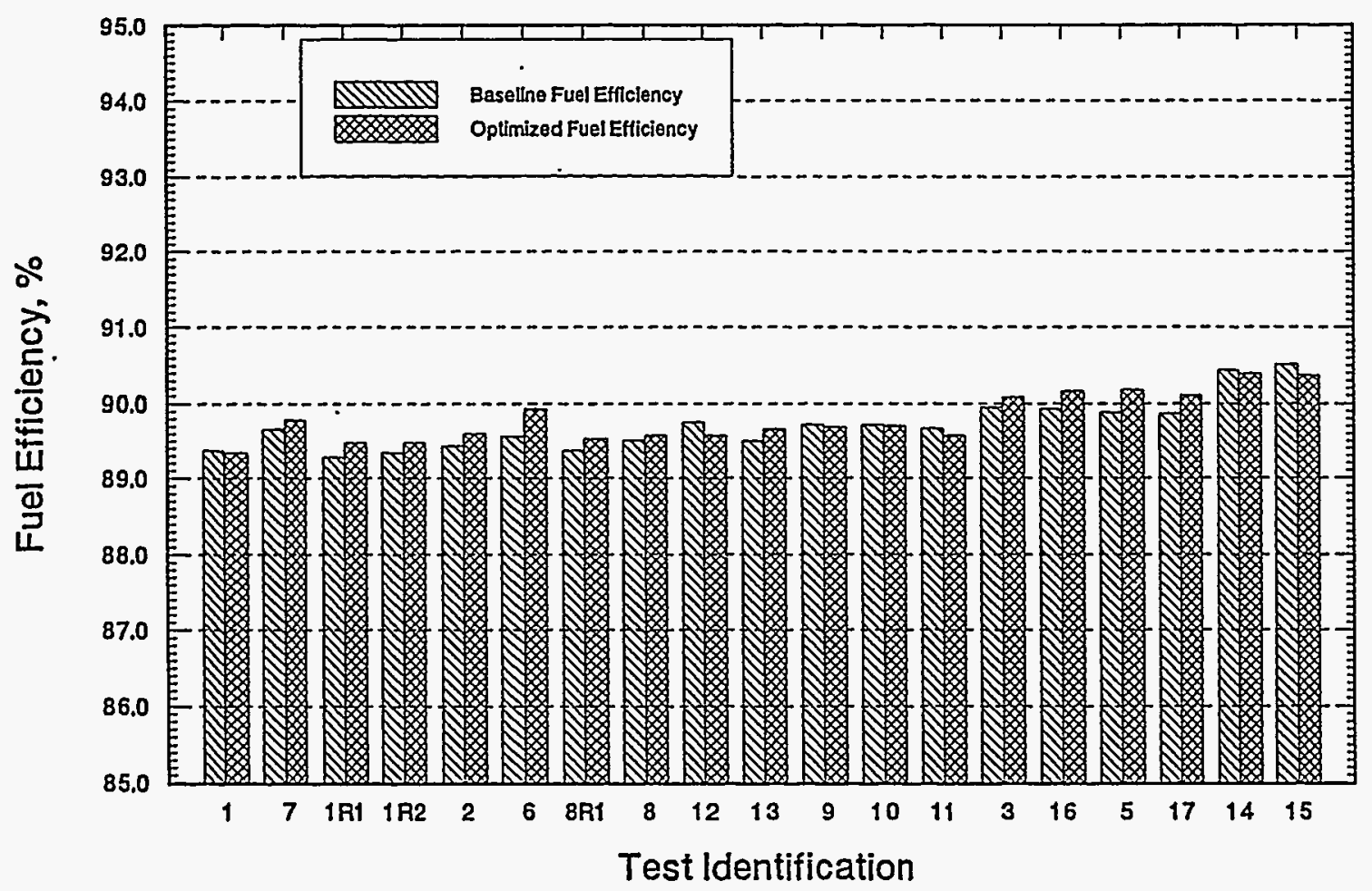

Figure 5-23 Fuel efficiency

During the optimization testing, average stoichiometry at the burner was 58\%. The balance of the air needed for combustion was injected by the $\mathrm{NO}_{\mathrm{x}}$ port located immediately above the burner for the regular arrangement cells or immediately below the burner for the inverted arrangement. Regardless of $\mathrm{NO}_{\mathrm{x}}$ port locations, stoichiometry at each burner was maintained the same following the parametric testing.

5.2.4.8 Effect on Unit Load. Maximum unit load was not affected by the LNCB ${ }^{\mathrm{TM}}$ burner conversion. Because JMSS4 had a universal pressure (once-through) boiler design, the superheater steam temperature was controlled by the firing rate and the steam flow was controlled by the feedpump. Reheater steam temperature was controlled by attemperation and excess air level. Gas recirculation was originally used in stead of excess air, but this feature has been eliminated.

Attemperation was used at the maximum continuous rating (MCR) to reduce the final reheat steam temperature, and excess air was used at lower loads to increase the final steam temperature to the design level. Reheater outlet steam temperature at the control load was $990^{\circ} \mathrm{F}, 13^{\circ} \mathrm{F}$ higher than that of the corresponding baseline test. There was no problem achieving the designed $\mathrm{RH}$ temperature at full load.

\subsection{Long-Term Operation}

After the $\mathrm{LNCB}^{\mathrm{TM}}$ retrofit and follow-up optimization testing in late 1991, JMSS4 underwent a long-term test period extending from July 1992 to April 1994. The objective of this test was to determine overall unit performance which included emissions, waterwall corrosion potential, and overall operability of the LNCB $^{T M}$ system. 
5.3.1 Operating Experience. Operating performance of the $\mathrm{LNCB}^{\mathrm{TM}}$ equipment has been satisfactory after final burner arrangements and the coal impeller modifications were completed in April 1992. The LNCB' $^{T M}$ have provided stable combustion conditions with acceptable carbon burnout.

The amount of flyash produced has increased, while the amount of bottom ash produced decreased. Flyash appeared to be finer after the burner retrofit compared to that of baseline testing. Even though overall dust loading entering the ESPs has increased, precipitator performance has actually improved.

Prior to the burner retrofit, the standard cells produced a buildup of agglomerated "popcorn" ash on the horizontal sections in the convection pass of the boiler, particularly on the economizer. This ash buildup and associated tube erosion has been greatly reduced since installation of the $\mathrm{LNCB}^{\mathrm{TM}}$ burners. Required maintenance for the airheaters, flyash handling equipment, and bottom ash handling equipment has also been reduced due to the condition of the ash produced by the $\mathrm{LNCB}^{\mathrm{MM}}$ burners.

For purposes of long-term corrosion evaluation of the furnace waterwalls, DP\&L reported that sulfur concentration in the as-received coals supplied to the Stuart Station during the long-term test period, i.e., from August 1992 to April 1994, averaged 1.24\%.

5.3.2 Emissions Summary. An important aspect of the project was to document $\mathrm{NO}_{\mathrm{x}}$ emission levels from JMSS4 under normal load dispatch operations over a long period of time. Table 5-4 shows these $\mathrm{NO}_{\mathrm{x}}$ emissions with all mills in service as measured by Acurex using CEM equipment through each of the economizer outlet ducts. These data were acquired between August 1992 and March 1993, during which the boiler operated at above 590 MWe. The number of days in each month the unit operated at full load with all mills in service is shown in the first column. The remaining days were at lower loads resulting from mills out-of-service and/or the CEM being out-of-service or in calibration.

The average $\mathrm{NO}_{\mathrm{x}}$ level achieved for the eight month period was $0.49 \mathrm{lbm} / 10^{6} \mathrm{Btu}$ or a $58 \%$ reduction from baseline values. During the same period, excess $\mathrm{O}_{2}$ levels averaged 3.2\%. The highest average of $\mathrm{NO}_{\mathrm{x}}$ at $0.56 \mathrm{lbm} / 10^{6} \mathrm{Btu}$ was observed in January, which was probably attributed to burning wet coal and associated problems. However, a $52 \%$ reduction in $\mathrm{NO}_{\mathrm{X}}$ was still achieved.

Table 5-5 summarizes the $\mathrm{NO}_{\mathrm{x}}$ emission levels recorded at full load and mill out-of-service conditions during this same period. The lower $\mathrm{NO}_{\mathrm{x}}$ levels calculated with either $\mathrm{A}$ or $\mathrm{F}$ mill out-of-service may have been caused by these pulverizers feeding only the burners at the upper row.

5.3.3 Laboratory Corrosion Study. The laboratory corrosion study evaluated the corrosion resistance of various alloys and coatings to simulated low- $\mathrm{NO}_{\mathrm{x}}$ combustion environments in a $\mathrm{B} \& \mathrm{~W}$ research facility. A total of five retort tests were performed, each exposed for 1000 hours. After the tests, corrosion rates of the materials were carefully determined and their performance was examined. Results of the laboratory corrosion study were used to evaluate the potential impact of $\mathrm{LNCB}^{\mathrm{TM}}$ burners on furnace wall corrosion and to develop predictive equations for estimating the corrosion rates of materials (see "LongTerm Testing Report" for detailed corrosion rate results).

All of the materials tested were available in the form of commercial tubings and coatings, which are summarized as follows: 
Table 5-4

LONG-TERM EMISSIONS DATA - FULL LOAD WITH ALL MULS IN SERVICE

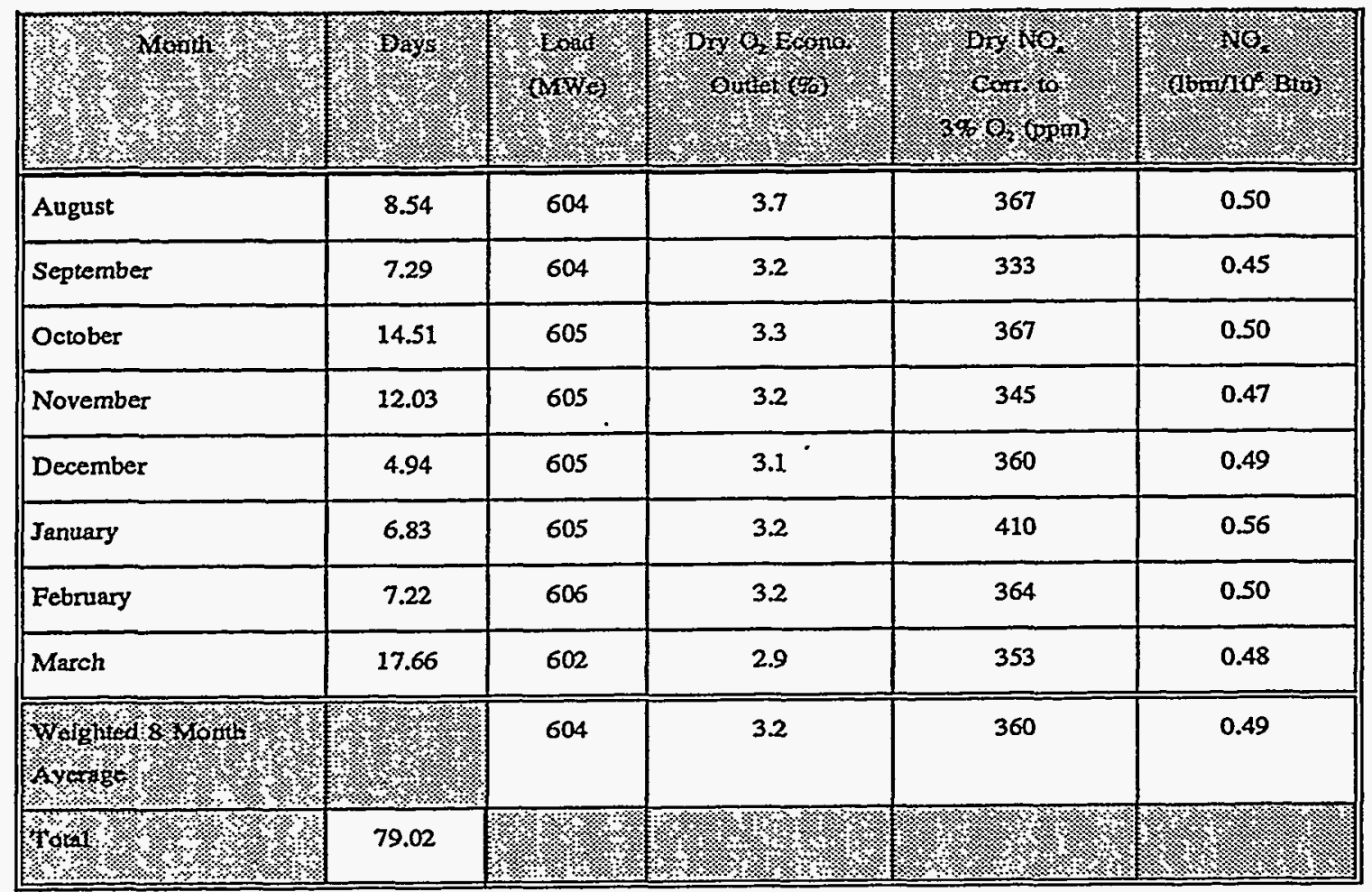

Table 5-5

LONG-TERM EMISSIONS DATA - FULL LOAD WITH ONE MILL OUT OF SERVICE

\begin{tabular}{|c|c|c|c|c|c|}
\hline 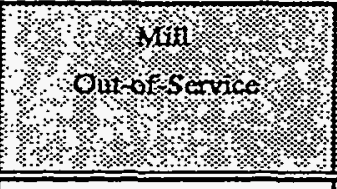 & whors & 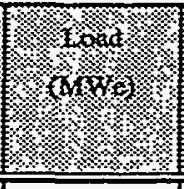 & 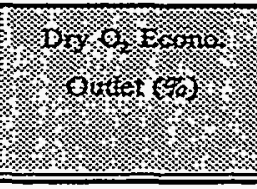 & 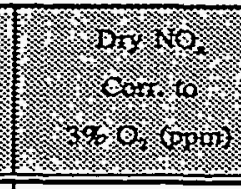 & $f^{2}+10 \%$ \\
\hline A & 1.04 & 603 & 3.4 & 314 & 0.43 \\
\hline B & 1.81 & 608 & 3.6 & 361 & 0.49 \\
\hline C & 1.41 & 602 & 3.5 & 388 & 0.53 \\
\hline D & 2.29 & 602 & 3.6 & 404 & 0.55 \\
\hline $\mathbf{E}$ & 3.02 & 606 & 3.3 & 357 & 0.49 \\
\hline$F$ & 8.48 & 604 & 3.9 & 314 & 0.43 \\
\hline 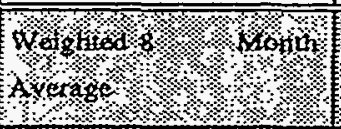 & 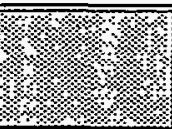 & 604 & 3.7 & 343 & 0.47 \\
\hline 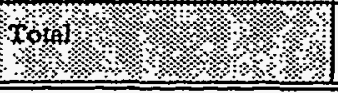 & 18.05 & 4848 & & & \\
\hline
\end{tabular}


- Tubing Material

- Carbon Steel:

SA178-A

- Low Alloy Steels: SA213-T2, SA213-T11, SA213-T22, and SA213-T9

- Stainless Steels:

SA213-TP304L, SA213-TP309, SA213-TP310, SA213-TP321, and Alloy 253MA

- Free-Standing Coating Materials (Not applied to a base metal)

- Fe-Cr-Al

- Fe-Ni-Cr-Al

- Commercial Coatings

- Al plasma-spray on SA213-T2 tube material

- FeCrAl plasma-spray on SA213-T2 tube material

- Cr/Si co-diffusion coated on SA213-T2 tube material

The laboratory tests consisted of five different exposure conditions, varying in temperature and $\mathrm{H}_{2} \mathrm{~S}$ concentration. These exposure conditions were designed to simulate a full range of reducing combustion environments most likely to occur in the lower furnace of utility boilers equipped with $\mathrm{LNCB}^{\mathrm{TM}}$ burners. In addition, the tests were performed with and without a simulated ash deposit.

Results from the laboratory testing indicated that the carbon and low-alloy steels commonly used in the lower furnace of utility boilers would suffer accelerated wastage from sulfidation attack under low- $\mathrm{NO}_{\mathrm{x}}$ combustion. The corrosion rates were also significantly increased with increasing temperature. Stainless steels and higher-Cr coatings, on the other hand, exhibited very little metal loss. Therefore, the use of chromia-forming coating materials in boilers where reducing flue gases are expected may be necessary.

Due to the significant difference in corrosion rates between the low alloy and high alloy steels, two corrosion rate predictive equations were developed. The predictive equations are as follows:

- Equation 1 - Carbon and low-alloy steels $(0 \leq \mathrm{Cr}$ wt. $\% \leq 10)$

$$
C . R=3.2 \times 10^{5} \times \exp \left(-\frac{15818}{1.987 \times T}\right) \times\left[H_{2} S\right]^{0.574} \times \frac{1}{(C r \%+10.5)^{1.234}} \pm 2.2
$$

- Equation 2 - High-alloy steels (Cr wt.\% $\geq 16)$

$$
C . R_{0}=1.04 \times 10^{7} \times \exp \left(-\frac{19230}{1.987 \times T}\right) \times\left[H_{2} S\right]^{0.29} \times \frac{1}{(C r \%-1.40)^{1.37}} \pm 1.2
$$

where:

$$
\begin{array}{ll}
\text { C.R. } & =\text { Corrosion rate (mils per year) } \\
\mathrm{T} & =\text { Tube metal temperature }\left({ }^{\circ} \mathrm{K}\right) \\
\mathrm{H}_{2} \mathrm{~S} & =\text { Hydrogen sulfide concentration }(\mathrm{ppm}) \\
\mathrm{Cr} \% & =\text { Chromium content of the material }(\text { wt. } \%)
\end{array}
$$

The applicability of these equations has been partially validated by the field corrosion study, to be discussed in the following paragraphs. For additional information on the testing, refer to the Long Term Testing Report issued recently by $\mathrm{B} \& \mathrm{~W}$. 
5.3.4 Field Corrosion Study. During the $\mathrm{LNCB}^{\mathrm{TM}}$ burner installation in October-November 1991, a 12-foot high by 14-foot wide ( 80 tubes) corrosion test panel was installed on the furnace west sidewall. The panel consisted of the following four sections of commercial coatings separated by bare SA-213T2* tubing:

- Aluminized spray coating on T2 tube material

- 309L stainless weld overlay on T2 tube material

- 308L stainless weld overlay on T2 tube material

- Chromizing on T2 tube material

The panel extended from the bottom to the top of the lower cell burner elevations, essentially covering the entire lower burner zone on the half of the west sidewall near the front wall. Near the four corners of the test panel, through-membrane $1 / 2$-inch sampling ports and chordal thermocouples were built into the bare T2 tubing and were used to extract the gas samples and measure the metal temperature. In addition, UT measurements were performed on the surfaces of several sandblasted furnace areas and on the test panel.

After a total of 15-month exposure in JMSS4, segments of the top and bottom portions of the test panels were cut and sent to $\mathrm{B} \& W$ for destructive analysis. Results of the analysis revealed that localized corrosion near the center of the west sidewall has occurred. The tube wastage readings on bare $\mathrm{T} 2$ ranged from as little as $2 \mathrm{mpy}$ (mils per year) to a maximum of 18 mpy during the 15 months of operation. It is noted that this exposure time also included a 6-month operation prior to the burner inversion when high levels of $\mathrm{CO}$ and $\mathrm{H}_{2} \mathrm{~S}$ were found in the hopper.

The wastage on bare T2 also varied with tube metal temperature. Because JMSS4 is a two-pass furnace, the supercritical fluid flowing through the second pass tubes was hotter than the first pass. As a result, the second pass T2 tubes experienced higher metal losses than those of the first pass. Overall, the metal wastage rates on bare $\mathrm{T} 2$ under the low-NO ${ }_{\mathrm{x}}$ operation were not significantly higher than those reported by DP\&L prior to the burner retrofit, indicating that localized sulfidation attack by reducing gases was already a problem in JMSS4 under the operation of standard cells. All the coated tubes in the corrosion test panel exhibited excellent corrosion resistance to the low- $\mathrm{NO}_{\mathrm{x}}$ combustion gases.

Results from the UT survey performed before and after the long-term testing showed significant scattering in the remaining wall thicknesses. As a result, analysis of these UT data cannot produce a clear history of the furnace wall losses caused by the low-NO $\mathrm{N}_{\mathrm{x}}$ operation. It was later concluded that some corrective measures were needed in future UT surveys to improve the data accuracy and further UT testing was essential. Therefore, repeat of the UT surveys over the next few outages is necessary, along with destructive examinations of the test panel, to further evaluate the impacts of $L N C B^{\mathrm{TM}}$ burners on the waterwall corrosion and expand the materials database.

* Henceforth shortened to T2. Often referred to as Croloy $1 / 2$. 


\section{Section 6 \\ ECONOMICS}

This section provides an overview of the economics of Low-NO ${ }_{\mathrm{x}} \mathrm{Cell}^{\mathrm{TM}}$ burners $\left(\mathrm{LNCB}^{\mathrm{TM}}\right)$ as applied to commercial applications. $\mathrm{LNCB}^{\mathrm{TM}}$ technology was specially developed as a low-cost $\mathrm{NO}_{\mathrm{x}}$ reduction option applicable to an existing class of coal-fired, base-loaded utility boilers which were originally equipped with high performance but high $\mathrm{NO}_{\mathrm{x}}$ emitting "cell" burners. As such, it can only be viewed as a retrofit technology with costs which must be developed on a site-specific basis. Actual costs may vary significantly depending upon the initial condition of the boiler under consideration. In each retrofit, maximum use is made of existing components whenever possible to meet customer specific requirements at the lowest possible cost. The LNCB $^{\mathrm{TM}}$ concept was developed as a "plug-in" retrofit technology which does not require costly pressure part changes and minimizes other site modifications.

Since all boilers have existing burner systems with operational and maintenance costs, only incremental costs associated with the $\mathrm{LNCB}^{\mathrm{TM}}$ technology are considered. In many instances, $\mathrm{LNCB}^{\mathrm{TM}}$ retrofits may actually reduce many operating and maintenance costs over original equipment because of their improved mechanical design and improved combustion control.

\subsection{Economic Parameters}

6.1.1 Unit Size, Location, and Fuel. Cell burner equipped boilers range in size from $200 \mathrm{MWe}$ to $1300 \mathrm{MWe}$, although most (23 of 38) fall into the range of 480 to $800 \mathrm{MWe}$. Therefore, a $600 \mathrm{MWe}$ nominal unit size was selected as representative for commercial economic evaluation. A location in the midwest United States where most of the units are located is assumed with the unit burning a medium sulfur, medium volatile bituminous coal.

Key boiler and fuel attributes in the evaluation include:

- Nominal net boiler output

- Boiler baseline efficiency

- Coal flow

- Higher heating value

- Ash

- Capacity factor

- Fuel cost

- Initial $\mathrm{NO}_{\mathrm{x}}$ emissions

- $\mathrm{NO}_{\mathrm{x}}$ reduction

- Forced draft fan and motor efficiency

- Unburned carbon in ash (baseline)
$600 \mathrm{MWe}$

$89.5 \%$

$248 \mathrm{ton} / \mathrm{hr}$

$11,900 \mathrm{Btu} / \mathrm{lb}$

$13 \%$

$65 \%$

$\$ 39 /$ ton delivered

$1.2 \mathrm{lb} / 10^{6} \mathrm{Btu}$

$50 \%$

$60 \%$

$1 \%$ 
6.1.2 Other Assumptions. Other general assumptions provided in the PETC Participant Guidance Document \#3 (November 1993) have been used wherever possible. Selected changes and modifications appropriate for the $\mathrm{LNCB}^{\mathrm{TM}}$ technology are discussed where needed. All costs are provided in 1994 dollars unless otherwise indicated.

\subsection{Estimated Process Capital Costs}

6.2.1 Key Capital Cost Subsystems. A typical $\mathrm{LNCB}^{\mathrm{TM}}$ retrofit consists of three major cost areas: LNCB $^{\mathrm{TM}}$ hardware, controls upgrades, and furnace wall protection. Figures 6-1 and 6-2 (DOE Exhibits 3 and 4) provide the DOE financial summary information for these areas. Further supporting discussion follows.

6.2.1.1 $\mathrm{LNCB}^{\mathrm{TM}}$ Hardware. Materials for specific $\mathrm{LNCB}^{\mathrm{TM}}$ retrofits are estimated on a site-specific basis. Major components in such retrofits are shown in Figure 6-3 and typically include:

- Burner section of $L N C B^{\mathrm{TM}}$ with impeller

- $\mathrm{NO}_{\mathrm{x}}$ port section of $\mathrm{LNCB}^{\mathrm{TM}}$

- Ceramic-lined segmented coal elbow

- Ceramic-lined and non-ceramic lined fuel piping and supports (Y-Pipe Assembly and Support)

- Sliding air damper drivers

- Sliding gate valve

- Burner wallbox

- Coal pipe restrictors

- Thermocouples

- Magnehelic gauges

- Miscellaneous platform modifications

- Other site specific windbox modifications

- System engineering including flow modeling

- Start-up engineering services

The estimate provided in Figure 6-2 excludes installation of new lighters, flame scanners, and selected other components which may be re-used from the existing burner installation. No pressure part modifications are required along with a minimum of coal piping changes. Numerical flow modeling is part of the application engineering for cases which are significantly different from existing installations. This modeling reduces technical risk and permits performance optimization. Start-up service engineering costs are included with emphasis on balancing and adjustment of the equipment to achieve optimal performance during start-up.

The LNCB ${ }^{\mathrm{TM}}$ unit material and installation costs provided in Figure 6-2 were developed by preparing a complete site material cost estimates and then dividing by the number of cell burners -20 in this case. Some costs are directly related to individual cell burner assemblies while others are not. Therefore, the values provided in Figure 6-2 are not true unit costs, but are provided as an approximation. Multiplying the unit cost by the number of cell assemblies on other boilers will not necessarily provide accurate estimates. Site-specific cost evaluations are needed. 


\begin{tabular}{|c|c|c|c|c|c|c|c|}
\hline \multirow{2}{*}{$\begin{array}{l}\text { Item } \\
\text { No. }\end{array}$} & \multirow[b]{2}{*}{ Item Name } & \multicolumn{2}{|c|}{ Number } & \multirow{2}{*}{$\begin{array}{c}\text { Unit } \\
\text { Capacity }\end{array}$} & \multirow{2}{*}{$\begin{array}{c}\text { Design } \\
\text { Conditions* }\end{array}$} & \multirow{2}{*}{$\begin{array}{l}\text { Material of } \\
\text { Construction }\end{array}$} & \multirow[b]{2}{*}{ Vendo } \\
\hline & & In Use & Spare & & & & \\
\hline 1 & LNCB $^{T M}$ Burners & 20 & 0 & 30 Mwe each & See main text & See main text & B\&W \\
\hline 2 & Controls & 1 & 0 & 600 MWe & See main text & 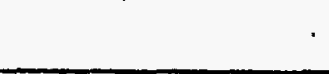 & Owner \\
\hline 3. & $\begin{array}{l}\text { Furnace } \\
\text { Prot." }\end{array}$ & 1 & 0 & 600 Mule & See main text & See main text & B\&WW \\
\hline & & & & & & & \\
\hline & & & & & & & \\
\hline & & & & & & & \\
\hline & & & & & & & \\
\hline & & & & & & & \\
\hline & & & & & & & \\
\hline & & & & . & & & \\
\hline
\end{tabular}

- Pressure, temperature, composition, flowrate, surface area, viscosity, special considerations (code, corrosion tolerance, etc.)

Figure 6-1 Exhibit 3 - Major equipment list 


\begin{tabular}{|c|c|c|c|c|c|c|c|c|c|c|}
\hline \multirow{2}{*}{$\begin{array}{l}\text { Item } \\
\text { No. }\end{array}$} & \multirow[b]{2}{*}{ Item Name } & \multicolumn{7}{|c|}{ Cost/Unit } & \multirow{2}{*}{$\begin{array}{l}\text { No. of } \\
\text { Units }\end{array}$} & \multirow{2}{*}{$\begin{array}{l}\text { Total } \\
\text { Cost }\end{array}$} \\
\hline & & $\begin{array}{l}\text { F.O.B. } \\
\text { Equip- } \\
\text { ment }\end{array}$ & $\begin{array}{c}\text { Sales } \\
\text { Tax }\end{array}$ & Freight & $\begin{array}{l}\text { Field } \\
\text { Mater- } \\
\text { ial }\end{array}$ & $\begin{array}{l}\text { Field } \\
\text { Labor }\end{array}$ & $\begin{array}{l}\text { Indirect } \\
\text { Field }\end{array}$ & Total & & \\
\hline 1 & $\mathrm{LiNCB}^{\mathrm{TM}}$ Burners & 103,370 & Incl. & 750 & *x* & 105,000 & $* *$ & 209,120 & 20. & $4,182,400$ \\
\hline & & & & & & & & & & \\
\hline & & & & & & & & . & & \\
\hline & & & & & & & & & & \\
\hline
\end{tabular}

[A] Subtotal Installed Cost

(B) Retrofit Costs ( 0 multiplier $\times A$ )

(C) Process Contingency $(0 \%$ of $(A+B))$.

[D] Total Installed Equipment Cost $(A+B+C)$

*iField Material separate from FOB Equipment is small. included in Field llabor.

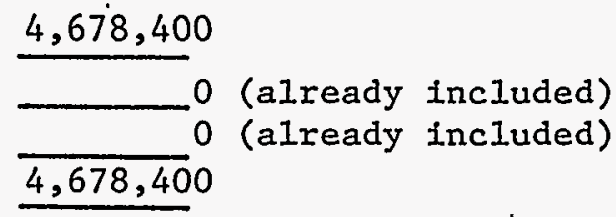

Indirect Field labor and small field material costs

Figure 6-2 Exhibit 4 - Major equipment costs (Area No. 500 - Refer to Exhibit 5) 


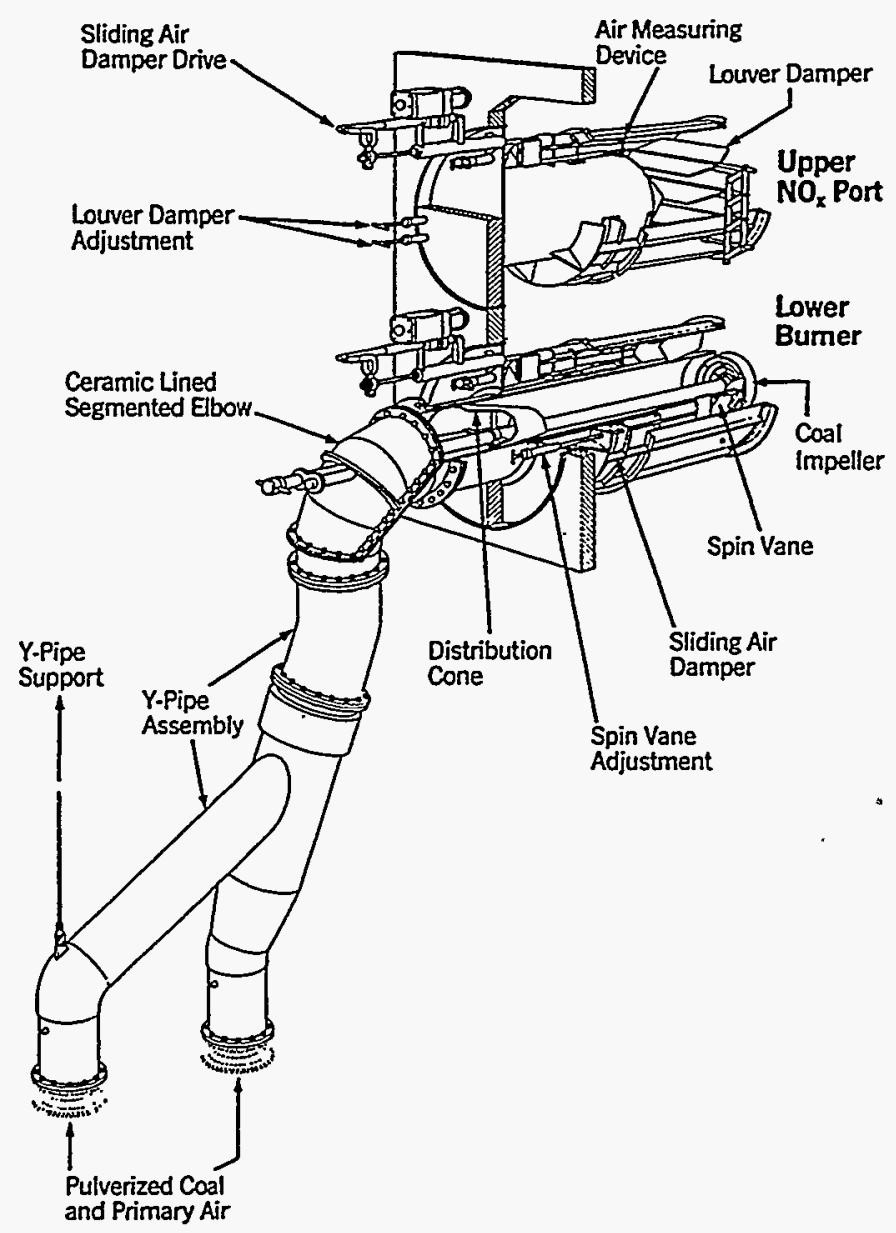

Figure 6-3 $\mathrm{LNCB}^{\mathrm{TM}}$ schematic

The burners are designed to handle the required coal flow and air flow while meeting velocity, erosion, performance, and other limits. The burners and $\mathrm{NO}_{\mathrm{x}}$ ports are generally fabricated from stainless and alloy steel because of the high temperature application. High alumina ceramic linings and components are provided for the coal pipe and burner nozzle to provide acceptable wear life. Lower temperature components are made of carbon steel where appropriate to control cost.

6.2.1.2 Controls Upgrades. As part of an $\mathrm{LNCB}^{\mathrm{TM}}$ retrofit, controls upgrades may be required, especially if the original burner equipment is still in use. The estimate for controls provided in Figure 6-2 includes engineering and materials for a typical boiler application where original equipment is still in use. In cases where original combustion equipment has already been upgraded to include control of air flow to individual burners (two per cell), then the controls revisions will be minimal. This has been the case in at least one retrofit application.

6.2.1.3 Furnace Coating (Corrosion Protection). As in any staged low- $\mathrm{NO}_{\mathrm{x}}$ system, there is the potential for furnace corrosion depending upon the fuel sulfur content. Some form of protection is prudent for many medium or high sulfur coals. The corrosion is also related to tube wall metal temperatures which tend to be higher in supercritical pressure boilers. Many supercritical pressure boilers equipped with cell burners already provide furnace wall corrosion protection by using panel coatings. For these units, no further protection is required. For other units, an evaluation of the fuel and possible furnace wall corrosion will need to be performed. 
To provide a reasonable basis for comparison, the initial process capital cost in Figure 6-2 includes application of furnace wall corrosion protection coatings to the boiler side-walls in the burner zone (about 15.75 feet) plus ten feet above and below. Surface preparation (grit blasting) and application of a chromized coating may cost $\$ 70-100 / \mathrm{ft}^{2}$ complete.

This type of coating typically lasts about five years, and the maintenance costs have been included to permit replacement over a five-year period.

6.2,1.4 Field Installation. Field installation costs are also site-specific for combustion system retrofits. Effectively all of the field material is provided as part of the FOB equipment and the bulk of the installation is field labor and indirect costs. Past experience has indicated that the total installation cost is $85 \%$ to $100 \%$ of the material price (including royalties and freight). The $100 \%$ number is used here to cover labor and indirect costs as a single value. No specific retrofit cost is provided in Figure 6-2 because the entire project cost is already estimated as a retrofit. Process contingency is set to zero since multiple fullscale units are now operating and meeting their performance goals.

\subsubsection{Other Options. Other options to be considered follow.}

6.2.2.1 Fans. Installation of low-NO ${ }_{x}$ burners as well as any combustion technology where air flow balancing is required will typically increase pressure loss in the system and the static head requirement of the forced draft (FD) fan. Most current systems have sufficient excess capacity to accommodate the 0.5 to $2.5 \mathrm{inch}$ W.G. pressure increase associated with the $\mathrm{LNCB}^{\mathrm{TM}}$ burners and therefore no provision is included here for upgrading the fans.

If existing fan capacity is limited at a specific site, then a number of options exist:

1. "Tip" the current fan to add static capacity and replace the motor if needed.

2. Replace the fan rotor with or without motor.

3. Replace the entire fan with or without motor.

Option 1 without a motor change is relatively inexpensive, costing $\$ 5,000$ to $\$ 8,000$ per fan completely installed. If a fan and motor change are needed, then the costs may exceed several million dollars.

6.2.2.2 Miscellaneous. Additional components may be added to the $\mathrm{LNCB}^{\mathrm{TM}}$ retrofit in order to further upgrade the reliability of the combustion system. While not required, these are sometimes added. Samples include:

- Flame scanners

- Lighters

6.2.3 Total Capital Cost. Figure 6-4 provides a completed version of DOE Exhibit 5, analyzing the total project capital requirement. All of the capital equipment is listed in Area 500. Selected other assumptions and notes include:

- General Facilities: Zero because all costs are included in Area 500.

- Project Contingency: 5\% because multiple commercial units have been constructed and costs are now well established. 
- AFUDC: Negligible since the period of time from first payment to commercial operation is short and usually less than 12 months in most cases.

- Royalty: Estimated amount based upon existing technology and repayment agreements.

- Preproduction Costs: A LNCB ${ }^{\mathrm{TM}}$ retrofit start-up is normally part of regular boiler outage start-up. Start-up costs are usually small and there are effectively no incremental operating costs during the start-up period. Engineering personnel required on site to monitor start-up and tune the system for optimal performance are included in Area 500 equipment cost estimates.

- Cost of Construction Downtime: $\mathrm{LNCB}^{\mathrm{TM}}$ installation is normally scheduled as part of a routine boiler outage in the spring or fall. Therefore, a cost for outage time has not been included here. If a separate outage for the $\mathrm{NO}_{\mathrm{x}}$ retrofit is required, then a replacement power cost would be incurred.

\subsection{Projected Operating and Maintenance Costs}

Figure 6-5 provides a completed version of DOE's Exhibit 6 summarizing the incremental fixed and variable operating costs associated with the sample commercial $\mathrm{LNCB}^{\mathrm{TM}}$ retrofit. Actual costs may be quite variable depending upon specific pre-retrofit conditions. If the unit is older and has not been significantly upgraded from its original combustion system hardware, it is possible to see no incremental operating costs. The unit may actually experience a net credit for lower maintenance and improved boiler thermal efficiency. The information in Figure 6-5 provides a somewhat conservative approach to illustrate major factors which should be considered in a system. A site-specific assessment will be needed to determine actual expected costs.

6.3.1 Fixed Operating and Maintenance Costs. These costs are detailed in the following paragraphs.

6.3.1.1 Operating Labor. There are no incremental operators required for the $\mathrm{LNCB}^{\mathrm{TM}}$ retrofit.

6.3.1.2 Maintenance. Modern burners are generally low-maintenance devices. The $\mathrm{LNCB}^{\mathrm{TM}}$ technology takes advantage of burner design improvements, high temperature materials, and erosion resistant ceramic components to minimize any required routine upkeep. The main replacement wear part is the coal impeller (see Figure 6-3) which experiences wear and high temperatures. However, the pre-retrofit cell burners all use coal impellers with related wear issues so no increased maintenance is expected for the $\mathrm{LNCB}^{\mathrm{TM}}$.

Furnace wall coatings to reduce the potential of corrosion on the boiler side-walls was included as an initial capital cost. However, the chromized coating deteriorates with time and is typically replaced every five years. Provision has been made to set aside $20 \%$ of the installed coating cost each year under maintenance to re-coat the walls. Note that many of the existing cell burner equipped boilers are oncethrough supercritical pressure systems which have higher inherent tube wall metal temperatures and corrosion potential. Many of these units are already coated to reduce maintenance costs. The incremental costs for these units would then be negligible.

A general budget of $\$ 5000$ / year has been provided for miscellaneous incremental costs, although none have been identified yet. There are no incremental administrative costs expected. 


\begin{tabular}{|c|c|c|c|c|}
\hline $\begin{array}{c}\text { Area } \\
\text { No. }\end{array}$ & Total Installed Equipment Cost* & $\$ 10^{6}$ & $\$ / \mathrm{kW}$ & Notes \\
\hline 100 & Raw material receiving and handling system & & & \\
\hline 200 & Fuel preparation and storage system & & & \\
\hline 300 & Fuel and oxidant feed handling system & & & \\
\hline 400 & Combustion/steam generation system & & & \\
\hline 500 & Combustion modification equipment & 4.678 & 7.80 & \\
\hline 600 & Fuel gas processing and handling system & & & \\
\hline 700 & Power generating system & & & \\
\hline 800 & $\mathrm{SO}_{2}$ removal system & & & \\
\hline 900 & $\mathrm{NO}_{x}$ removal system & & & \\
\hline 1000 & Particulate removal system & & & \\
\hline 1100 & Flue gas handling system & & & \\
\hline 1200 & Raw material regeneration system & & & \\
\hline 1300 & By-Product processing and handling system & & & \\
\hline 1400 & Waste handling system & & & \\
\hline 1500 & Common support systems & & & \\
\hline 1600 & Other systems & & & \\
\hline$(A)$ & Total Process Capital (sum of process areas) & 4.678 & 7.80 & \\
\hline (B) & General Facilities $(0 \%$ of $A)$ & 0 & 0 & 1 \\
\hline (C) & Engineering and home office fees (10 \% of $A$ ) & 0.468 & 0.78 & \\
\hline (D) & Project contingency $(5 \%$ of $A+B+C)$ & 0.234 & 0.39 & \\
\hline (E) & Total Plant Cost $(A+B+C+D)$ & 5.380 & 8.97 & \\
\hline$(\bar{F})$ & Allowance for funds during construction ( $0 \%$ of E) & 0 & 0 & \\
\hline (G) & Total Plant Investment $(E+F)$ & 5.380 & 8.97 & \\
\hline$(\mathrm{H})$ & Royalty allowance $(-\%$ of $A)$ & 0.018 & 0.03 & 2 \\
\hline (I) & Preproduction costs (- months of startup) & 0 & 0 & 3 \\
\hline$(J)$ & Inventory capital & 0 & 0 & \\
\hline$(\bar{K})$ & Initial catalyst and chemicals & 0 & 0 & \\
\hline$(\mathrm{L})$ & Subtotal Capital $(\mathrm{G}+\mathrm{H}+\mathrm{I}+\mathrm{J}+\mathrm{K})$ & 5.398 & 9.00 & \\
\hline$(\mathrm{M})$ & Cost of construction downtime & 0 & 0 & 4 \\
\hline$(\mathrm{N})$ & Total Capital Requirement $(L+M)$ & 5.398 & 9.00 & \\
\hline
\end{tabular}

From Exhibit 4. Includes retrofit costs and process contingencies.

Notes: 1. There are no other general facilities required. All costs included.

2. Royalty based upon repayment plans

3. Start-up costs for engineering personnel included in lines " 500 " and " $\mathrm{C}$ ".

4. Installed during regular sprino, or Fall outage.

Figure 6-4 Exhibit 5 - Total capital requirement 


\begin{tabular}{|c|c|c|c|c|}
\hline Fixed O\&M Costs & Units & Quantity & \$/Unit & $\$ 10^{6} / \mathrm{yr}$ \\
\hline Operating labor & Man hr/hr & 0 & 23.00 & 0 \\
\hline \multicolumn{4}{|l|}{ Maintenance labor } & 0.045 \\
\hline \multirow{2}{*}{\multicolumn{4}{|c|}{$\begin{array}{l}\text { Maintenance material (See text) } \\
\text { Administration/support labor }\end{array}$}} & : : \\
\hline & & & & 0 \\
\hline \multicolumn{4}{|l|}{ Subtotal Fixed Costs } & 0.045 \\
\hline Variable Operating Costs & Units & Quantity & \$/Unit & $\$ 10^{6} / \mathrm{yr}$ \\
\hline \multicolumn{5}{|l|}{ Fuels } \\
\hline Methane & $10^{3} \mathrm{ft}^{3} / \mathrm{hr}$ & & 2.47 & \\
\hline Coal (Unburned carbon) & $\tan / v x$ & 2611 & 39 & 0.102 \\
\hline \multicolumn{5}{|l|}{ Sorbent } \\
\hline \multirow[t]{2}{*}{ Limestone } & Ton/hr & & 15.00 & \\
\hline & 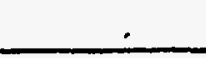 & & & \\
\hline \multicolumn{5}{|l|}{ Chemicals/Catalyst } \\
\hline Ammonia & Ton/hr & & 150.00 & \\
\hline \multicolumn{5}{|l|}{ Utilities } \\
\hline Condensate & $10^{3} \mathrm{lb} / \mathrm{hr}$ & & 0.77 & \\
\hline Raw water & $10^{3} \mathrm{gal} / \mathrm{hr}$ & & 0.60 & \\
\hline Cooling water & $10^{3} \mathrm{gal} / \mathrm{hr}$ & & 0.16 & \\
\hline LP steam ( 0.70 psia) & $10^{3} \mathrm{Ib} / \mathrm{hr}$ & & 2.85 & . \\
\hline MP steam (70-250 psia) & $10^{3} \mathrm{lb} / \mathrm{hr}$ & & 3.50 & \\
\hline HP steam ( $>250$ psia) & $10^{3} \mathrm{lb} / \mathrm{hr}$ & & 5.30 & \\
\hline Electric power & $\mathrm{kWh} / \mathrm{hr}$ & $536 \mathrm{~kW}$ & 0.05 & 0.153 \\
\hline \multicolumn{5}{|l|}{ By-Product credits } \\
\hline Sulfuric acid & Ton/hr & & 50.00 & \\
\hline \multicolumn{5}{|l|}{ Waste Disposal Charges } \\
\hline Dry solids (trucked-landfill) & Ton $/ \mathrm{hr}$ & & 9.29 & \\
\hline \multicolumn{4}{|c|}{ Subtotal Variable Cost } & 0.255 \\
\hline \multicolumn{4}{|c|}{ TOTAL O\&M COST (FIXED + VARIABLE) } & 0.300 \\
\hline
\end{tabular}

Notes: 1) Capacity factor - $65 \%$.

2) See the report text for a discussion of the coal (effect of unburned carbon

. loss) and electrical power operating costs.

3) These operating costs are considered conservative. In many cases, there will be no change in unburned carbon (ie no incremental coal cost) and the pressure drop increase may be as low as $0.5 \mathrm{in.wg}$. This would result in incremental variable operating costs of $\$ 33,000$ instead of $\$ 255,000$ per year.

Figure 6-5 Exhibit 6-Operating and maintenance cost 
6.3.2 Variable Operating Costs. Incremental operating costs for the LNCB $^{\mathrm{TM}}$ burner are relatively small and basically involve increases in air flow pressure loss through the burners and changes in overall boiler efficiency. Actual costs will be dependent upon the initial boiler condition. Some units with original cell burners will likely experience an increased pressure loss through the burner of up to 2.5 inches of water. However, the overall boiler efficiency may actually improve due to less unburned carbon loss, less slagging, lower $\mathrm{O}_{2}$ due to better air balancing, and lower air heater exit temperature. Other units have already been upgraded from the original cell burners to the more mechanically reliable S-Type circular burner. In these cases, the pressure drop increase from the $\mathrm{LNCB}^{\mathrm{TM}}$ retrofit may be as small as 0.5 inch W.G. The unburned carbon may rise somewhat while the slagging and air heater exit temperature may not change.

\subsubsection{Fan Power. All low- $\mathrm{NO}_{\mathrm{x}}$ burner retrofits tend to increase air flow pressure loss in order to} permit balancing the air flows between burners. The $\mathrm{LNCB}^{\mathrm{TM}}$ retrofit is no exception. However, current studies indicate that the pressure loss increase may be 0.5 to 2.5 inches W.G. This requires some additional power to be supplied to the forced draft (FD) fans depending upon the fan control scheme. The boiler air flow rate and 2.3 inches W.G. pressure loss have been assumed here to evaluate a power demand of $536 \mathrm{~kW}$ (see Figure 6-5). The DOE cost of electricity $(\$ 0.05 / \mathrm{kWh}$ ) has been used, representing the opportunity loss to sell power. In some systems, an internal power cost is used which is significantly less than the $\$ 0.05 / \mathrm{kWh}$.

6.3.2.2 Unburned Carbon Loss and Boiler Efficiency. The installation of any low- $\mathrm{NO}_{\mathrm{x}}$ burners tends to increase the loss of carbon from the boiler system as part of the ash. The LNCB ${ }^{\mathrm{TM}}$ retrofit is no exception. However, the change can vary from 0 to $1 \%$ carbon in ash. Some units may actually experience an improvement in unburned carbon loss due to improved air and fuel balancing. If the unburned carbon in ash increases with an associated loss of boiler efficiency, the efficiency loss may still be entirely offset by other improvements in boiler operation as a result of the $\mathrm{LNCB}^{\mathrm{TM}}$ retrofit. If the original burner equipment is in place, then an $\mathrm{LNCB}^{\mathrm{TM}}$ retrofit will tend to reduce furnace slagging, reduce required excess $\mathrm{O}_{2}$ levels, and reduce the air heater outlet temperatures. All of these changes improve net boiler efficiency. During the DP\&L Stuart Station demonstration, there was no overall effective deterioration in boiler efficiency.

A relatively poor case has been assumed here with an initial loss of $1 \%$ carbon in the ash before retrofit and $2 \%$ after. This gives a net change of $1 \%$ carbon in the ash (note that this is $1 \%$ of the coal ash which is collected, not $1 \%$ of the carbon in the fuel). Calculations indicate that an additional 2611 tons of coal per year will be needed to compensate for the extra heat loss and achieve the original boiler electricity output.

\subsection{Summary of Performance and Economics}

Figure 6-6 provides the summary of the overall performance information for the commercial unit as requested by DOE (Exhibit 7).

A brief review of the current cell burner boiler population indicates that these figures may be too conservative. An alternate scenario for the same unit might include the following:

- Furnace corrosion protection already used prior to retrofit (net $\$ 0 / \mathrm{kW}$ ).

- The combustion system and controls have already been upgraded (net $\$ 0 / \mathrm{kW}$ ).

- Unburned carbon loss changes little and is compensated for by lower $\mathrm{O}_{2}$ operation, less slagging and lower air heater outlet temperature. 


\begin{tabular}{|c|c|c|c|c|c|}
\hline \multicolumn{3}{|c|}{ Power Plant Attributes } & \multicolumn{2}{|r|}{$\overline{\text { Units }}$} & Value \\
\hline \multicolumn{3}{|l|}{ Plant capacity, net } & \multicolumn{2}{|r|}{ MWe } & 600 \\
\hline \multicolumn{3}{|l|}{ Power produced, net } & \multicolumn{2}{|c|}{$10^{9} \mathrm{kWh} / \mathrm{yr}$} & 3.416 \\
\hline \multicolumn{3}{|l|}{ Capacity factor } & \multicolumn{2}{|c|}{$\%$} & 65 \\
\hline \multicolumn{3}{|l|}{ Plant life } & \multicolumn{2}{|r|}{$\overline{\mathrm{yI}}$} & $: 15$ \\
\hline \multicolumn{3}{|l|}{ Coal feed } & \multicolumn{2}{|c|}{$10^{5}$ tons/yr } & 248 \\
\hline \multicolumn{3}{|l|}{ Sulfur in coal } & \multicolumn{2}{|c|}{ wt \% } & N/A \\
\hline Emissions Control Datz & Units & $\overline{\mathrm{SO}_{2}}$ & \multicolumn{2}{|c|}{$\mathrm{NO}_{\mathrm{x}}$} & $\overline{\mathbf{P M}_{10}}$ \\
\hline Removal efficiency & $\%$ & -- & \multicolumn{2}{|c|}{$50 \%$} & $\therefore$ \\
\hline Emissions standard & $\mathrm{Ib} / 10^{6} \mathrm{Btu}$ & $\overline{--}$ & \multicolumn{2}{|c|}{-} & -- \\
\hline Emissions without controls & $\mathrm{lb} / 10^{6} \mathrm{Btu}$ & $\overline{--}$ & \multicolumn{2}{|c|}{1.20} & 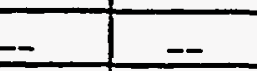 \\
\hline Emissions with control & $1 \mathrm{~b} / 10^{6} \mathrm{Btu}$ & - & & .60 & - \\
\hline \multirow{2}{*}{ Amount removed } & tons/yr & -- & 10,0 & & -- \\
\hline & \multicolumn{2}{|c|}{ Current Dollars } & & \multicolumn{2}{|c|}{ Constant Dollars } \\
\hline Levelized Cost of Power & Factor & Mills/kW & & Factor & Mills/kWh \\
\hline Capital Charge & 0.160 & 0.253 & & 0.124 & 0.196 \\
\hline Fixed O\&M Cost & 1.314 & 0.017 & & 1.000 & 0.013 \\
\hline Variable Operating Cost & 1.314 & 0.098 & & 1.000 & 0.075 \\
\hline Total Cost & - & 0.368 & & - & 0.284 \\
\hline Levelized Cost & Factor & \$/ton remo & & Factor & \$/ton removed \\
\hline Capital Charge & 0.160 & 85.96 & & 0.124 & 66.62 \\
\hline Fixed O\&M Cost & 1.314 & 5.89 & & 1.000 & 4.48 \\
\hline Variable Operating Cost & 1.314 & 33.35 & & 1.000 & 25.38 \\
\hline Total Cost & - & 125.20 & & - & 96.48 \\
\hline $\begin{array}{c}\text { Levelized Cost }-\mathrm{SO}_{2}+\mathrm{NO}_{\mathbf{z}} \\
\text { Basis }\end{array}$ & Factor & S/ton remo & & Factor & S/ton removed \\
\hline Capital Charge & 0.160 & $\overline{--}$ & & 0.124 & -- \\
\hline Fixed O\&M Cost & 1.314 & - & & 1.000 & -- \\
\hline Variable Operating Cost & 1.314 & - & & 1.000 & $=$ \\
\hline Total Cost & - & 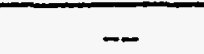 & & - & -_ \\
\hline
\end{tabular}

Notes: 1) Includes higher conservative operating costs for fan and unburned carbon in ash.

2) See text Section 6.4 for the results of a less conservative more realistic scenerio.

Figure 6-6 Exhibit 7 - Summary of performance and cost data 
The results are provided in the following summary on a constant-1994 dollar basis.

Base Case Alternate Case

$\begin{array}{llcc}\text { Capital } & (\$ / \mathrm{kW}) & 9.00 & 8.05 \\ & \text { (mills } / \mathrm{kWh}) & 0.196 & 0.175 \\ \text { O\&M } & \text { (mills } / \mathrm{kWh}) & 0.088 & 0.016 \\ \text { Total } & \text { (mills } / \mathrm{kWh}) & 0.284 & 0.191 \\ \text { \$/ ton } & \mathrm{NO}_{\mathrm{x}} \text { removed } & 96.48 & 64.89\end{array}$




\section{Section 7 \\ COMMERCIALIZATION POTENTIAL AND PLANS}

\subsection{Market Analysis}

\subsubsection{Application of the Technology}

7.1.1.1 Retrofit Existing Cell Burner Boilers. The Low-NO ${ }_{x}$ Cell ${ }^{\mathrm{TM}}$ burner $\left(\mathrm{LNCB}^{\mathrm{TM}}\right)$ technology is applicable for the retrofit of all coal-fired boilers using a two-nozzle cell configuration. The candidate boilers range in size from $200 \mathrm{MWe}$ to $1300 \mathrm{MWe}$ and were all built by Babcock and Wilcox (B\&W) between 1966 and 1975. In addition, this technology can potentially be adapted to related three-nozzle cell configuration burners.

The boilers equipped with standard cell burners are inherently high emitters of nitrogen oxides $\left(\mathrm{NO}_{\mathrm{x}}\right)$ and as a result, cell burners have not been installed on new U.S. manufactured coal-fired boilers since 1975. The $\mathrm{LNCB}^{\mathrm{TM}}$ was specifically designed as a "plug-in" cell burner retrofit to significantly reduce $\mathrm{NO}_{\mathrm{x}}$ emissions while minimizing retrofit costs.

7.1.1.2 Types of Coal. There are no restrictions imposed by the current $\mathrm{LNCB}^{\mathrm{TM}}$ technology on the types of coal which can be fired through the burners. B\&W has technology which will permit the application of $\mathrm{LNCB}^{\mathrm{TM}}$ burners to a wide range of coals.

7.1.1.3 $\mathrm{NO}_{\mathrm{x}}$ Results. Application specific burner zone heat release rates, furnace configuration, and coal type (e.g., volatility, fixed carbon level, bituminous versus subbituminous, nitrogen content, and oxygen content, etc.) will impact expected $\mathrm{NO}_{\mathrm{x}}$ results. Boilers firing fuels similar to Dayton Power \& Light (DP\&L) J. M. Stuart Station are expected to experience at least a $50 \% \mathrm{NO}_{\mathrm{x}}$ reduction when retrofitted with $\mathrm{LNCB}^{\mathrm{TM}}$ technology.

Units with higher burner zone heat release rates than J. M. Stuart Station will generally have higher baseline $\mathrm{NO}_{\mathrm{x}}$ levels. For these units, $\mathrm{LNCB}^{\mathrm{TM}}$ technology has the potential to reduce $\mathrm{NO}_{\mathrm{x}}$ emissions by $50 \%$ from baseline levels, but not necessarily to absolute levels as low as those attained at DP\&L Stuart Station.

7.1.1.4 Boiler Performance. The pre-retrofit burner equipment at DP\&L had not been upgraded from its original configuration. The air registers on most of the pre-retrofit burners had been welded in an open position, and no work had been performed recently to balance air and fuel flows. Therefore, some combustion-related items such as furnace exit gas temperature (FEGT), surface cleanliness, and unburned carbon results were improved by the mechanical improvements and air balancing capability of the $\mathrm{LNCB}^{\mathrm{TM}}$ equipment.

If a unit is similar to Stuart Station where there has been no major burner equipment or combustion upgrades, then similar results can be expected. However, if mechanical improvements have already been 
made to the burners such that "per burner air control" and/or per burner fuel/air balancing has been improved, then:

- FEGT may be slightly higher than baseline. Numerical modeling results indicated that in a balanced configuration, a $10^{\circ} \mathrm{F}$ increase in FEGT may result.

- Surface cleanliness will not show as dramatic an improvement because combustion efficiency will have already been improved.

- Unburned carbon losses may be slightly higher. The impact was minimized during the DOE demonstration program because the Stuart Station unit fuel/air flow was not balanced.

All other performance-related parameters should have the same pre- to post-retrofit results as the DP\&L Stuart Station demonstration.

7.1.1.5 Equipment. The forced draft (F.D.) fan equipment at DP\&L was adequate to handle the 2 inches of water pressure drop increase. The forced draft fans on other units will have to be evaluated on a caseby-case basis. Fan blade tipping or even fan replacement along with fan motor upgrades may be required.

7.1.1.6 Corrosion Potential. Laboratory results suggest that there is a significant potential for localized furnace tube wall corrosion to occur. However, this risk is no greater than the risk associated with any other two-stage combustion process (i.e., overfire air system). There is evidence to suggest that the risk is no greater than the potential for corrosion with the current cell burner equipment. It is strongly recommended that steps be taken at the time of installation of this or any other staged combustion process, to also add commercially available products such as wall coatings that retard furnace wall corrosion.

7.1.1.7 Limestone Requirements. The $\mathrm{LNCB}^{\mathrm{TM}}$ technology addresses the reduction of $\mathrm{NO}_{\mathrm{x}}$ and therefore limestone injection is not relevant for this technology.

\subsubsection{Technological Uncertainties}

- $\mathrm{NO}_{\mathrm{x}}$ - As previously noted in Section 7.1.1.3, job specific burner zone heat release rates, furnace design, and coal type/chemistry will impact expected $\mathrm{NO}_{\mathrm{x}}$ reduction. Currently, there are two operating units in the database to characterize performance results. Until such time as additional field data (i.e., actual commercial results) are obtained, $\mathrm{NO}_{\mathrm{x}}$ reduction levels for lower volatility coals contain some degree of uncertainty. Boilers firing similar or lower ASTM rank fuels to DP\&L Stuart Station are expected to produce similar or larger $\mathrm{NO}_{\mathrm{x}}$ reductions. Numerical models developed during the program will be combined with $\mathrm{NO}_{\mathrm{x}}$ reduction experience with other low- $\mathrm{NO}_{\mathrm{x}}$ burners to establish commercial guarantees and minimize uncertainty and risk.

- Corrosion - Long-term field data to confirm the laboratory results are currently limited. Analysis of actual field conditions at DP\&L Stuart Station will continue. The impact on corrosion for units firing higher sulfur coal will also need to be evaluated on a case-by-case basis.

- $\mathrm{LNCB}^{\mathrm{TM}}$ Applied to Three-Nozzle Cell Units - The benefits or risks of applying LNCB ${ }^{\mathrm{TM}}$ technology to units equipped with three nozzle cells is unknown. A research and development program would be prudent; however, such a program does not appear justifiable due to the small population of domestic boilers equipped with the three-nozzle burner arrangement. 
There are five units that are currently equipped with three-nozzle cell burners representing $1500 \mathrm{MWe}$ of capacity. An arrangement to combine the three nozzles into two would need to be developed. Because only one-third of the throat openings would be converted to louvered $\mathrm{NO}_{\mathrm{x}}$ ports, as compared to one-half in the case of the two-nozzle $\mathrm{LNCB}^{\mathrm{TM}}$ burner, the amount of $\mathrm{NO}_{\mathrm{x}}$ reduction àchievable would need to be demonstrated before being guaranteed. Numerical modeling based upon experience gained during the DP\&L demonstration can be used to evaluate potential performance and reduce uncertainty and risk.

7.1.2 Market Size. The total original market for two- and three-nozzle cell, pulverized-coal-fired units consisted of 38 units with a generating capacity of over $26,000 \mathrm{MWe}$. Five of these units employ the three-nozzle cell design. Although it is anticipated that the $\mathrm{LNCB}^{\mathrm{TM}}$ can be adapted for this application, the technology has not yet been demonstrated for the three-nozzle cell burners. Accounting for the threenozzle cell burner equipped capacity and current commitments for low- $\mathrm{NO}_{\mathrm{x}}$ combustion systems, including LNCB, the market can be summarized in Table 7-1.

Table 7-1

\section{MARKET SUMMARY*}

\begin{tabular}{lrc} 
Total Original Capacity & 38 & $26,700 \mathrm{MWe}$ \\
Three-Nozzle Cells (Future Potential) & 5 & 1,500 \\
Other Technology Sales, Retrofits, and Options & $\underline{6}$ & $\underline{5,600}$ \\
Net Available LNCB & 27 & 19,600 \\
Existing LNCB $^{\mathrm{TM}}$ Sales, Retrofits, and Options & $\underline{8}$ & $\underline{5,500}$ \\
& 19 & $14,100 \mathrm{MWe}$ \\
Future Available Market for LNCB & \\
\hline * All base-loaded units & &
\end{tabular}

7.1.3 Market Barriers. The only known technical market barriers to retrofitting the two-nozzle cell units are those listed under technological uncertainties in Section 7.1.1.8 above. As is the case for all $\mathrm{NO}_{\mathrm{x}}$ reduction retrofits, local regulatory approvals will be required on a site-specific basis.

7.1.4 Economic Comparison With Competing Technologies. LNCB $^{\mathrm{TM}}$ burners offer one alternative for reducing $\mathrm{NO}_{\mathrm{x}}$ on affected cell burner equipped coal-fired boilers. Conventional low- $\mathrm{NO}_{\mathrm{x}}$ circular burners are another alternative. The use of low- $\mathrm{NO}_{\mathrm{x}}$ burners on a cell burner equipped unit typically requires physical modifications to the boiler waterwalls, windbox, and support steel to permit burner respacing and implementation. These burners are available from several manufacturers and can be used with or without furnace staging (overfire air ports). Other post-combustion technologies may also be considered such as selective non-catalytic reduction (SNCR) deNO ${ }_{x}$ systems and selective catalytic reduction (SCR) $\mathrm{NO}_{\mathrm{x}}$ control systems. A variety of other technologies are also under development.

A recent economic comparison of technologies for an approximate $300 \mathrm{MWe}$ boiler retrofit application involving the LNCB ${ }^{\mathrm{TM}}$ techology is provided in the Table 7-2. A low-sulfur coal was the fuel for comparison, reducing the risk of furnace wall corrosion. The basis for this comparison is somewhat different from that provided in Section 6. Capital costs are presented here on a delivered and erected turnkey basis in 1994 dollars. 
COMPARISON MATRIX - TYPICAL 300 MWe PLANT

\begin{tabular}{|c|c|c|c|c|c|}
\hline Technology & $\mathrm{INCB}^{\mathrm{m}}$ & $\begin{array}{l}\text { Conv. } \\
\text { Low No } \\
\text { Burner }\end{array}$ & $\begin{array}{c}\text { Low No } \\
\text { Burner \& } \\
\text { Overfire } \\
\text { Air } \\
\end{array}$ & SNCR & $\operatorname{SCR}$ \\
\hline \multicolumn{6}{|l|}{ 1. Typical performance } \\
\hline Inlet No $\left(2 \mathrm{~b} / 10^{6} \mathrm{Btu}\right)$ & 1.2 & 1.2 & 1.2 & 1.2 & 1.2 \\
\hline Outlet No $\left(1 \mathrm{~b} / 10^{\circ} \mathrm{Btu}\right)$ & 0.6 & 0.6 & 0.4 & 0.6 & 0.25 \\
\hline 8 Reduction & 50 & 50 & 67 & $30-50$ & 80 \\
\hline Removal (ton/kw/yx) & 0.025 & 0.025 & 0.034 & $\begin{array}{c}0.015- \\
0.025 \\
\end{array}$ & 0.041 \\
\hline \multicolumn{6}{|l|}{ 2. Operating Costo } \\
\hline - Type & Fan Pwr & Fan Pwr & Fan Pwr & $\begin{array}{l}\text { Ammonia } \\
\text { Fan Pwr }\end{array}$ & $\begin{array}{l}\text { Ammonia } \\
\text { Fan Pwr } \\
\text { CatalyBt }\end{array}$ \\
\hline$-\operatorname{cogt}(s / \mathrm{kw} / \mathrm{yr})$ & 0.25 & 0.25 & 0.25 & $13-16$ & 5.5 \\
\hline $\begin{array}{l}\text { 3. Capital cost ( } \$ / \mathrm{kW}) \\
\text { (Installed Turnkey) }\end{array}$ & 7 & 14 & 20 & 20 & 90 \\
\hline $\begin{array}{l}\text { 4. Annual Cost ( } \$ / \mathrm{kw} / \mathrm{Yr}) \\
\text { (Capltal \& operating) }\end{array}$ & 1.2 & 2.1 & 2.9 & $13-19$ & 17 \\
\hline 5. $\$ /$ ton Nox Removed & 48 & 84 & 85 & $760-870$ & 415 \\
\hline 6. Presвure Part Changes & No & Yes & Yes & Yes & No \\
\hline 7. Post Combustion Equip. & No & No & No & Yes & Yes \\
\hline 8. Reagent Consumption & No & No & No & Yeg & Yes \\
\hline 9. Catalyst Replacement & No & No & No & No & Yeg \\
\hline
\end{tabular}

Note: This table 18 based upon a separate evaluation than that presented in section 6 . The capital costs are provided delivered and erected turnkey basis and do not include all of the EPRT factors. The comparison between products is, however, believed to be consigtent and representative of these commercial systems.

\subsection{Commercialization Plans}

7.2.1 Commercialization of the $\mathrm{LNCB}^{\mathrm{TM}}$ Technology. The $\mathrm{LNCB}^{\mathrm{TM}}$ technology is currently being commercialized by B\&W. A full-scale demonstration has been conducted at Dayton Power \& Light's J.M. Stuart Station No. 4. LNCB $^{\mathrm{TM}}$ burners have been sold for installation on three units and two units have requested options for installation.

- Engineering/Manufacturing: Design and engineering information has been incorporated into B\&W standards and procedures. Fabrication and manufacturing of the $\mathrm{LNCB}^{\mathrm{TM}}$ technology have been integrated with B\&W's ongoing coal-fired burner manufacturing activities. Several orders for commercial orders have already been completed.

- Marketing: Marketing, sales, and contract management are being conducted through B\&W's existing Energy Services Division on a routine basis. This includes sales presentations, product literature preparation, and contracting activities, among others. A key element of this process was the $\mathrm{LNCB}^{\mathrm{TM}}$ Advisory Committee composed of most of the cell-burner equipped boiler owners. As members of this group, most of the potential $\mathrm{LNCB}^{\mathrm{TM}}$ customers became familiar with the technology, reviewed field data, became familiar with the supporting numerical modeling technology, and provided inputs to the demonstration. Therefore, as individual boilers become effected by the 1990 Amendments to the Clean Air Act or local regulations, the owners will be in strong position to consider $\mathrm{LNCB}^{\mathrm{TM}}$ technology. A significant segment of the market summarized in Section 7.1.3 will likely not take action until Phase II of the CAAA implementation. $\mathrm{B} \& W$ is working closely with each customer to identify how best to address their $\mathrm{NO}_{\mathrm{x}}$ control needs through its existing national sales force. 
Appendix A

ENVIRONMENTAL IMPACTS 


\title{
ENVIRONMENTAL IMPACTS
}

\section{BABCOCK \& WILCOX LOW-NOX CELL BURNER DEMONSTRATION PROJECT}

\author{
by \\ Acurex Environmental Corporation \\ 555 Clyde Ave \\ Mountain View, CA 94039
}

Environmental measurements were made by Acurex Environmental Corporation during the course of the low-NO $\mathrm{N}_{x}$ Cell Burner (LNCB) demonstration to quantify changes in the concentration of pollutants in some waste discharge streams as a result of the LNCB retrofit. Quantitation of these potential environmental impacts focused on the flue gas discharges with limited analyses performed on solid and liquid discharges. Because the LNCB alters the rate of coal burning in the furnace to suppress $\mathrm{NO}_{\mathrm{x}}$ formation, its only environmental impacts are limited to potential changes in the composition of flue gas and flyash leaving the furnace. The following sections discuss in brief the recorded changes in emissions that are attributed to the operation of DP\&L Stuart Station Unit 4 with LNCB. These measurements were made during the short-term parametric and optimization tests following the retrofit of the LNCB and during the long-term monitoring of the flue gas emissions following the optimization of LNCB operation.

\section{Flue Gas Emissions}

During the period of May 14 to June 30, 1992, Acurex Environmental performed the following air emissions measurements:

- $\quad$ Flue gas monitoring for $\mathrm{NO}_{\mathfrak{v}} \mathrm{NO}, \mathrm{CO}, \mathrm{O}_{2}$, and $\mathrm{CO}_{2}$ at the economizer outlet using a continuous monitoring system, and total hydrocarbon using a separate monitoring system

- Particulate size and mass emissions measurements with selected analyses of unburned carbon content on the ash (loss on ignition)

- Fly ash resistivity measurements and particulate mass emissions at the stack to quantitate the changes in flyash collection efficiency of the existing precipitator.

Table 1 summarizes the $\mathrm{NO}_{x}$ data for the three major test periods. The data shows the net reduction in $\mathrm{NO}_{x}$ from baseline levels under different boiler load and mill pattern operating conditions. The long-term data indicates lower $\mathrm{NO}_{x}$ levels compared to the optimization testing because the average includes all boiler loads with indicated mill out of service (OOS). Compared 
to baseline operation, with conventional cell burners, the LNCB retrofit reduced $\mathrm{NO}_{x}$ level to approximately $409 \mathrm{ppm}$ (0.55 lb/MMBtu) at full load with all mills in service, or approximately a 51 percent drop. Actual $\mathrm{NO}_{x}$ emissions recorded during the optimization tests were found to vary with selected mill pattern, boiler load, and excess oxygen as in the case of the baseline operation. Long-term operation with all mills in service indicated an average $\mathrm{NO}_{x}$ level of $353 \mathrm{ppm}(0.47$ lb/MMBtu).

Table 1. Summary of Average Baseline, Optimization and Long-Term $\mathrm{NO}_{\mathbf{x}}$ Emissions

\begin{tabular}{|l|c|c|c||}
\hline Boiler/Mill Settings & $\begin{array}{c}\text { Baseline } \\
\text { Pre-Retrofit }\end{array}$ & $\begin{array}{c}\text { Optimization } \\
\text { Post-Retrofit }\end{array}$ & $\begin{array}{c}\text { Long-Term } \\
\text { Post-Retrofit }\end{array}$ \\
\hline Full load/ all mills & $843(1.13)$ & $409(0.55)$ & $353(0.47)$ \\
\hline Full load/ A OOS & $752(1.01)$ & $357(0.48)$ & $293(0.39)$ \\
\hline Full load/ B OOS & $780(1.05)$ & $364(0.49)$ & $345(0.46)$ \\
\hline Full load/ C OOS & $842(1.13)$ & $397(0.53)$ & $352(0.47)$ \\
\hline Full load/ D OOS & $842(1.13)$ & $427(0.57)$ & $352(0.47)$ \\
\hline Full load/ E OOS & $784(1.06)$ & $364(0.49)$ & $311(0.42)$ \\
\hline Full load/ F OOS & $727(0.98)$ & $370(0.50)$ & $305(0.41)$ \\
\hline Intermediate load/ A OOS & $641(0.86)$ & $305(0.41)$ & $\mathrm{e}$ \\
\hline Low load/ A \& F OOS & $520(0.70)$ & $271(0.36)$ & $250(0.34)$ \\
\hline
\end{tabular}

a - dry ppm corrected to 3 percent $\mathrm{O}_{2}$

b - lb/MMBtu

c - OOS: Out of service

$\mathrm{d}$ - Long-term is average of eight months of testing and includes all loads with indicated mill pattern

Table 2 summarizes $\mathrm{CO}$ emissions measured during the same time period. Average $\mathrm{CO}$ emissions ranged between 60 and $126 \mathrm{ppm}$ during baseline, were recorded lower during the two post-retrofit testing phases indicating improved combustion efficiency and burner air/fuel balance. An increase in flyash loading was recorded during the LNCB optimization tests compared with baseline levels. This is not surprising because lower peak combustion temperatures in the furnace tend to reduce slagging with a consequent increase in flyash partitioning at the expense of lower bottom ash loadings. The total inorganic matter fed to the boiler is strictly a function of the feedrate and ash content of the coal. These were not impacted by the LNCB retrofit. Hydrocarbons were not detected in the flue gas during either baseline or LNCB operation indicating no measurable impact of low- $\mathrm{NO}_{x}$ operation on these emissions. 
Table 2. Summary of Average Baseline, Optimization and Long-Term CO Emissions

\begin{tabular}{||l|c|c|c||}
\hline Boiler/Mill Settings & $\begin{array}{c}\text { Baseline } \\
\text { Pre-Retrofit }\end{array}$ & $\begin{array}{c}\text { Optimization } \\
\text { Post-Retrofit }\end{array}$ & $\begin{array}{c}\text { Long-Term }^{d} \\
\text { Post-Retrofit }^{\text {fill }}\end{array}$ \\
\hline Full load/ all mills & $126(0.10)$ & $35(0.029)$ & $23(0.019)$ \\
\hline Full load/ A OOS & $79(0.065)$ & $30(0.025)$ & $34(0.028)$ \\
\hline Full load/ B OOS & $104(0.085)$ & $14(0.011)$ & $16(0.013)$ \\
\hline Full load/ C OOS & $104(0.085)$ & $12(0.010)$ & $22(0.018)$ \\
\hline Full load/ D OOS & $60(0.049)$ & $15(0.012)$ & $26(0.021)$ \\
\hline Full load/ E OOS & $77(0.063)$ & $10(0.008)$ & $32(0.026)$ \\
\hline Full load/ F OOS & $86(0.071)$ & $25(0.020)$ & $25(0.020)$ \\
\hline Intermediate load/ A OOS & $122(0.10)$ & $41(0.034)$ & $\mathrm{e}$ \\
\hline Low load/ A \& F OOS & $97(0.080)$ & $10(0.008)$ & $21(0.017)$ \\
\hline
\end{tabular}

a - dry ppm corrected to 3 percent $\mathrm{O}_{2}$

$\mathrm{b}-\mathrm{lb} / \mathrm{MMBtu}$

c - OOS: Out of service

d - Long-term is average of five months of testing and includes all loads with indicated mill pattern

e - Data included in average for full load

Loss on ignition (LOI) during the baseline tests indicted a range of 0.28 to 2.02, with an average of 0.94 percent. The percent LOI for the post retrofit flyash increased indicating a slight loss in carbon utilization. LOI was measured by three different methods indicating a range between 0.88 and 2.73 percent with an average of 2.05 for all samples analyzed by ASME PTC 28-1965 method. This one percent increase in the average LOI is not unusual for staged combustion burners that reduce $\mathrm{NO}_{x}$ in coal flames.

Other measurement results indicate little impact from the LNCB retrofit at the Stuart Station. For example, particle size ranged from about 19 to $53 \mu \mathrm{m}$. The corresponding average particle size for the post-retrofit tests ranged between 13 and $25 \mu \mathrm{m}$. Particle resistivity was found to be statistically unchanged.

\section{Wastewater Discharge Streams}

No wastewater discharge streams were measured during any of the test phase either prior or following the retrofit of the LNCB. Therefore, no comments can be made with regard to any measured environmental impact.

\section{Solid Waste Streams}

Solid streams sampled during these testes were limited to the bottom and ESP hopper ash discharge 
streams for the purpose of measuring unburned carbon content. Additional measurements were performed on the flyash samples collected at the inlet to the precipitator. Analyses on these samples were limited to the particle size and LOI discussed above. Measurements of LOI on the bottom and ESP discharge streams were performed by Babcock \& Wilcox. 